\title{
Transnational Flows and
}

Permissive Polities

\section{Ethnographies of Human Mobilities in Asia}

EDITED BY BARAK KALIR AND MALINI SUR

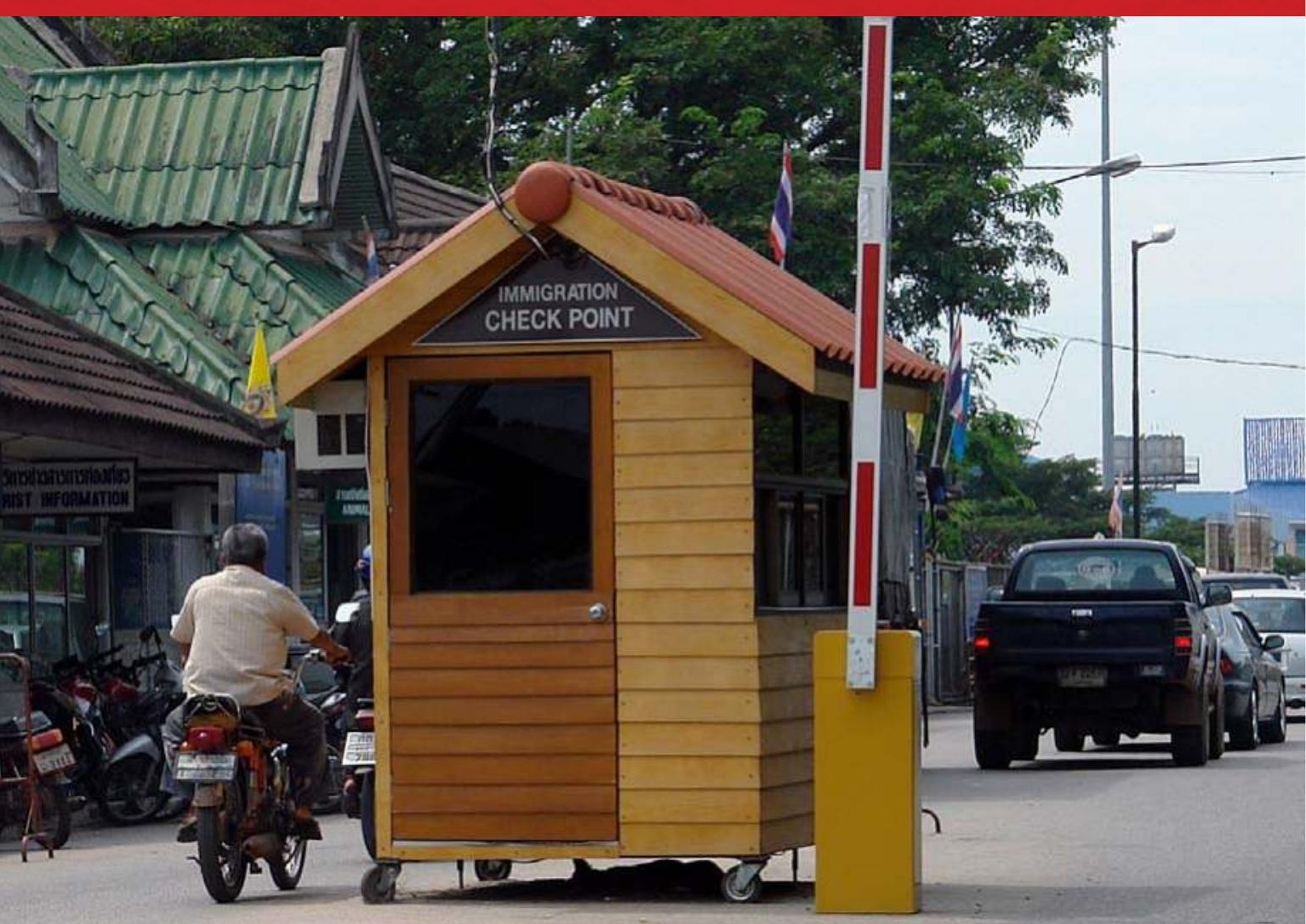


Transnational Flows and Permissive Polities 


\section{IIAS Publications Series}

International Institute

for Asian Studies

\section{General Editor}

Paul van der Velde

\section{Publications Officer}

Martina van den Haak

\section{Editorial Board}

Prasenjit Duara (Asia Research Institute, National University of Singapore) / Carol Gluck (Columbia University) / Christophe Jaffrelot (Centre d'Études et de Recherches Internationales-Sciences-po) / Victor T. King (University of Leeds) / Yuri Sadoi (Meijo University) / A.B. Shamsul (Institute of Occidental Studies / Universiti Kebangsaan Malaysia) / Henk Schulte Nordholt (Royal Netherlands Institute of Southeast Asian and Caribbean Studies) / Wim Boot (Leiden University)

The IIAS Publications Series consists of Monographs and Edited Volumes. The Series publishes results of research projects conducted at the International Institute for Asian Studies. Furthermore, the aim of the Series is to promote interdisciplinary studies on Asia and comparative research on Asia and Europe.

The International Institute for Asian Studies (IIAS) is a postdoctoral research centre based in Leiden and Amsterdam, the Netherlands. Its objective is to encourage the interdisciplinary and comparative study of Asia and to promote national and international cooperation. The institute focuses on the humanities and social sciences and, where relevant, on their interaction with other sciences. It stimulates scholarship on Asia and is instrumental in forging research networks among Asia scholars worldwide.

IIAS acts as an international mediator, bringing various parties together, working as a clearinghouse of knowledge and information. This entails activities such as providing information services, hosting academic organisations dealing with Asia, constructing international networks, and setting up international cooperative projects and research programmes. In this way, IIAS functions as a window on Europe for non-European scholars and contributes to the cultural rapprochement between Asia and Europe.

For further information, please visit www.iias.nl. 


\section{Transnational Flows and Permissive Polities}

\section{Ethnographies of Human Mobilities in Asia}

Edited by

Barak Kalir and Malini Sur 
IIAS Publications Series

International Institute

for Asian Studies

Edited Volumes 7

Cover illustration: Traffic passing a movable border checkpost at the Thailand-Malaysia border, 2007. Photographer: Willem van Schendel

Cover design: Maedium, Utrecht

Layout: The DocWorkers, Almere

ISBN 9789089644084

e-ISBN 9789048515875 (pdf)

e-ISBN 9789048515882 (ePub)

NUR 76I/ 906

(C IIAS / Amsterdam University Press, Amsterdam 2012

All rights reserved. Without limiting the rights under copyright reserved above, no part of this book may be reproduced, stored in or introduced into a retrieval system, or transmitted, in any form or by any means (electronic, mechanical, photocopying, recording or otherwise) without the written permission of both the copyright owners and the author of the book. 


\section{Table of Contents}

List of Tables, Maps, Figures and Photographs 7

Acknowledgements 9

$\begin{array}{ll}\text { Introduction } & 11\end{array}$

Mobile Practices and Regimes of Permissiveness

Barak Kalir, Malini Sur and Willem van Schendel

I Illegality Rules

Chinese Migrant Workers Caught Up in the Illegal but Licit Operations of Labour Migration Regimes

Barak Kalir

2 Contesting the State of Exception in the Afghan-Pakistani Marchlands

Oskar Verkaaik, Sarfraz Khan and Samina Rehman

3 'Looking for a Life'

Rohingya Refugee Migration in the Post-Imperial Age

Diana Wong and Tan Pok Suan

4 Smuggling Cultures in the Indonesia-Singapore Borderlands

Michele Ford and Lenore Lyons

5 Trade, Transnationalism and Ethnic Infighting

Borders of Authority in Northeast Borneo

Laurens Bakker and Jay Crain

6 Bamboo Baskets and Barricades

Gendered Landscapes at the India-Bangladesh border

Malini Sur 
$7 \quad$ Moving between Kerala and Dubai

Women Domestic Workers, State Actors and the Misrecognition of Problems

Bindhulakshmi Pattadath and Annelies Moors

8 Emigration of Female Domestic Workers from Kerala 169 Gender, State Policy and the Politics of Movement Praveena Kodoth and V.J. Varghese

9 Mainland Chinese Migrants in Taiwan, 1895-1945 The Drawbacks of Being Legal

Leo Douw

Io 'Playing Edge Ball'

Transnational Migration Brokerage in China

Li Minghuan

Epilogue

Irregular Mobilities and Disjunctive Moralities

Hastings Donnan

About the Editors and Contributors

Bibliography

Index 


\section{List of Tables, Maps, Figures and Photographs}

\section{Tables}

Table 1.1 Table of spaces of competing authorities 47

Table 1.2 Table of legitimacy of state executive power 48

Table 10.1 Table of self-given reasons of becoming indentured workers abroad

\section{Maps}

Map 4.1 Map of Riau Islands 93

Map 6.1 Map of Northeast India and Bangladesh $\quad 130$

Map 6.2 Map of India and Pakistan $1947 \quad 135$

Map 6.3 Map of India and Bangladesh $1971 \quad 135$

Map 6.4 Map of Northeast India 136

\section{Figures}

Figure 1.1 Number of Chinese migrant workers reaching Israel (in thousands) 29

Figure 1.2 Deported undocumented migrants, 1995-2001 41

\section{Photographs}

Photo 6.1 The India-Bangladesh border: A Garo trader crossing the river boundary 139

Photo 6.2 Garo traders at a border market 139

Photo 6.3 Products displayed at a border market 140

Photo 6.4 The border market: Domachi 140 



\section{Acknowledgements}

This volume is one of the outcomes of a research programme entitled 'Illegal But Licit: Transnational Flows and Permissive Polities in Asia'. We gratefully acknowledge that the programme - initiated by the University of Xiamen (China) and the University of Amsterdam (the Netherlands) - was financed by the Netherlands Organization for Scientific Research (NWO). Many other institutions facilitated the programme, including the Amsterdam Institute for Social Science Research; the Centre for Development Studies in Thiruvananthapuram, India; the Institute for Social and Environmental Transition in Kathmandu, Nepal; and the University of Peshawar in Pakistan.

In addition to the contributors to this volume, we would also like to take this opportunity to thank our many colleagues in China, Bangladesh, India, Pakistan, Nepal, United Arab Emirates, Israel, Australia, the United States and the Netherlands for their stimulating involvement at various stages and in various events of the 'Illegal But Licit' programme. We acknowledge the International Institute for Asian Studies (IIAS) for their support, and especially thank Paul van der Velde and Martina van der Haak.

Barak Kalir and Malini Sur

Amsterdam, April 2012 



\title{
Introduction
}

\section{Mobile Practices and Regimes of Permissiveness}

\author{
Barak Kalir, Malini Sur and Willem van Schendel
}

This is a book about transnational mobile practices. The contributors share a common concern: to push social analysis beyond received notions of legality and illegality and to think outside the box of state authority versus criminal behaviour. In doing so, we join a growing group of social scientists searching for new ways to understand the relationship between human behaviour and multiple authorities. For us, simple dichotomies will not do; instead, we seek a more finely grained framework of interpretion. The chapters that follow contain new ideas, based on close empirical observation in various societies across the vast continent of Asia.

\section{Thinking Mobile}

Two critical points of departure shape our approach. First, we consider mobility to be an integral part of social life rather than its exception (Urry 2007). Second, we acknowledge that the existence of mobile communities preceded the formation of states (Ludden 2003). Thus, we think of the state as a political organisation keen to regulate existing or emergent patterns of mobility. States are of interest to us because they exert themselves in controlling and moulding mobilities within and across their national borders. Our contributions empirically explore the effects of such exertions. How do they affect, contain, increase, deflect or bypass mobile practices?

From this perspective, the state often appears as reactive rather than proactive: it has to run after the facts. In doing so, it is never a neatly coordinated machine with all its agents acting in unison. The real-life states that we have studied bear little resemblance to the 'model state' used in much social theory. Looked at from the vantage point of people participating in (illegal) transnational flows, these states turn out to be far less tightly structured and much less governed by uniform, impersonal rules. Our studies demonstrate that these states suffer from a 
persistent 'implementation deficiency' - an inability to put their policies into practice. There are two dimensions to this. On the one hand, policies are often overambitious and the state lacks the manpower and legitimacy to push them through. On the other hand, officials may actively obstruct policies handed down from higher levels within the state. There are many reasons why they may do so: they may disagree with the policies (a lack of 'political will' within the state), they may feel the policies run counter to their personal interests or career prospects, or they may be out to divert state resources to their own coffers. Our studies show that despite elaborate performances of sovereignty, states are not able to imprint a unified normative project onto every subject, including those manning the state itself. We have encountered officials who were embedded in a certain locality and influenced by the norms and mores of that locality, officials who were not monitored by superiors and who developed their own understanding of formal policy, and officials who provided public services for payment.

The cases presented in this collection underline the importance of exploring the regulatory capacity of states empirically and comparatively. They also reveal the heuristic value of doing so by taking the views of people directly involved seriously, rather than being satisfied with taking a top-down perspective - 'seeing like a state' (Scott I998). We present three patterns. First, legislation plays a muted role in shaping the lives of citizens because of competing sources of authority within the state. Second, categories generated by states (or by interstate bodies such as the UN) are unable to regulate the realities that called them into existence, giving rise to a host of political and social negotiations. Third, for transnationally mobile people, there are more urgent aspirations than aligning their subjectivities to states. Their sense of identity and loyalty often eludes state categories of belonging. Even though they are well aware of such categories, they do not frame their mobility in such terms.

In what follows, we expand on each of these three points in order to clarify the limits of the regulatory capacity of states that seek to control the mobility of people and goods within and across their national borders. Our cases do not understand these limits as failures of real-life states vis-à-vis the 'model state'. On the contrary, we provide more positive conceptual tools for further exploration, such as 'controlled informality' (Kodoth and Varghese in this volume) and 'ecology of licitness'.

\section{Thinking Multiple}

Political order is commonly associated with the regulatory authority of states. This is not surprising in view of the fact that states do their utmost to project an image of exercising full authority within national 
territories. According to the formal model, states enjoy a monopoly over the use of violence, the right to tax the population and the power to sanction offenders. Staying close to such a formal understanding, it is easy to conceptualise state authority in a binary fashion: either there is state law and order, or there is a lack of authority and thus anarchy.

Our empirical evidence shows that the sway of formal state authority is never complete and, crucially, that we should not understand this as a 'lack' of authority. It is not just a question of states not having penetrated empty pockets, poorly defined border zones or other 'non-state spaces'. Our findings point to the necessary ubiquity of multiple authorities that complement or compete with the regulatory authority of states. For example, time-honoured ways of doing things can be more powerful in shaping people's practices than new regulations drafted in a government ministry. Religious, ethnic or commercial elites can exercise as much - or more - regulatory power than state officials.

But it is certainly not simply a matter of state/non-state regulation. Even more striking is that many states actually preside over multiple legal systems. Verkaaik, Khan and Rehman expand on the situation in Pakistan, where one set of laws applies to the so-called 'tribal areas' and another to the rest of the country. In their contribution, Bakker and Crain highlight the role of adat (local customary) rules for regulating trade among communities on the border of Indonesia and Malaysia. In such systems, intra-state negotiations of rules and how to apply them are never-ending. Social science analysis must reflect the basic multiplicity and malleability of state regulations and how mobile people navigate and contest them.

Furthermore, as Wong and Pok Suan's contribution reminds us, international regulations hem in the authority of individual states within their own territories. A system of increased accountability to an emerging global regime of human rights - anchored in international conventions drafted by the United Nations and the International Labour Organization - infringes on the regulative authority of states (Cornelius et al.I994; Jacobson I996; Sassen I999). Thus, state regulatory authority has become increasingly intertwined with inter-state regulation. At the same time, new illegal but licit migration zones such as a distinctive 'transnational Islamic space' (Bowen 2004) come into existence out of the tension that exists between intolerant political regimes (based on the strict letter of migration and citizenship laws) and communities that recognise and act according to cultural notions that transcend the categories of the territorial state. Here one can think of Muslim hospitality in the case of refugees in Saudi Arabia (Wong \& Pok in this volume), or the recognition of human dignity in the case of undocumented nonJewish migrants in Israel (Kalir in this volume). 
A further complication suggested by Bakker and Crain is that systems of regulation may reach across territorial boundaries, where they may mesh or clash. This expansion of state authority beyond the national territory can be driven by political actors as well as by mobile players in the private sector - for example, those who wish to pursue their economic interests by means of land or juridical concessions in another state's territory (Nyiri 2010).

Multiple regulative authorities are omnipresent, and they are by no means detrimental to the establishment of order. Clearly, we need better tools to study the relationship between multiple regulations and social order. As we have seen, widely used models of state regulatory authority are flawed because they do not take into account either the internal regulatory multiplicity of many states or the external systems of regulation with which states have to cope - whether these are religious, international or cross-border.

Actors drawing on a variety of sources of authority continuously negotiate with each other to agree on a mutually acceptable practice of rules on the ground. It is this successful negotiation that fosters a sense of order in a locality. This conciliatory order is always subject to attempts by distinct actors and groups to alter it in ways that favour their interests. For this reason, studying how negotiation establishes order and how it twists and turns over time can provide useful insights into the power relations between a variety of actors and their sources of authority. Many of our contributions show that one should not start from the assumption that state actors are always keen to have the letter of the law shaping realities on the ground. They can use the state's inherent 'implementation deficiency' to creatively negotiate a working relationship that suits all parties and their differing interests.

\section{Reassessing Categories}

Political organisations such as states and interstate associations need categories and rules. They cannot govern without abstracting the representations of lived realities to create these categories. However, the very act of creation shapes these realities (Cohn I996). New state categories are as informative as they are formative. Examples abound: 'terrorist,' 'human trafficking' and 'migrant and ethnic minorities' are just a few familiar ones.

As some of our contributors show, however, state categories often fail to capture the very phenomena they manifestly aim to order. For example, in both Israel and the United Arab Emirates, the category of 'guest workers' - which is supposed to describe a secure relationship of employment under standardised working and living conditions during an 
agreed period - turns out to be something else entirely. In practice, it describes a relationship in which employers enslave workers and which does not provide even basic legal protection against employer violations of signed contracts. For these migrants, paradoxically, legality turns into a liability. Indian domestic workers in Dubai and Chinese construction workers in Tel Aviv who deliberately opt to become 'runaway' workers or undocumented labourers find themselves in a surprising position. They are better off than their 'legal' counterparts, who are tied to binding contracts, excessive exploitation and extreme social isolation. Under these circumstances, absconding or fleeing a legal contract becomes a means of 'countering subjugation' rather than 'subjugation itself.

The flip side of legality as a liability for those who opt for informal work relationships is that state categorisation of migrant workers as 'illegal subjects' are likely to leave such workers more vulnerable to harsh criminal sentences and deportation. The deportability of 'illegal migrants' conditions them to an uncertainty that is emotionally taxing. Therefore, those who occupy zones of licitness are also embedded in constant struggles for legitimacy. What often determines their chances to become a recognisable 'claims-making group', in the eyes of the state, is the kind of relationships that 'illegal migrants' are able to establish with local civil society groups or international agencies that can assist them in public and legalistic campaigns. While Chinese construction workers in Israel received support for their claims from several local non-governmental organisations, Malayalee domestic workers in Dubai were often more isolated from civil society forums, as they worked informally for middle-class Malayalee families (Pattadath \& Moors in this volume). The emergence of migrant claim-making is dependent on migrants' agency as well as their particular civil and political circumstances and material conditions.

The distinction between the state as an idea and the state as an empirical object, a real-life organisation, runs through all the contributions to this book. As Das and Poole (2004) have argued earlier, that which lies at the edges of states as complex processes of partial belonging, and disorder, informs the state as a theoretical and political object. Everyday life at the margins of state, in other words, constitutes the state itself. Contributions to this collection further advance that state categories and rules are never straightforward, let alone set in stone. States make many rules only to break (or forget) these, either routinely or in specific circumstances. China's semi-state labour-export companies provide another example of state categories that fail to capture the very phenomena that they manifestly aim to order. These companies are formally in charge of overseeing the orderly and legal export of Chinese workers. In practice, however, they are key players in the systematic extortion of large informal fees from these workers. In India, as shown by Kodoth 
and Varghese (this volume), the gender categorisation of migrant workers is claimed to protect female migrant workers from exploitation but in reality often serves as an additional barrier to their mobility. Thus the women migrants are forced to find informal ways to exercise mobility, which are riskier and more expensive. Examples from states as unique as Singapore, Israel, Pakistan, China and Indonesia show that we must conceptualise states as entities habitually straddling the legalillegal divide - a divide of their own making. Whether we employ concepts such as 'the state of exception' (Agamben 2005), 'illegal state practices' (Heyman 1999), 'pluralisation of regulatory authority' (Roitman 2005) or 'undisputed legitimacy' (Kalir in this volume), we must acknowledge the Janus-faced nature of real-life states.

It takes a fair amount of naïveté to presume that state categories and regulations simply fall short of accurately representing the lived realities of social actors, and that they can be perfected with time and effort. We advance that the 'failure' is systemic because it is part of ongoing practical negotiations to establish social order. This puts a distinct complexion on these categories. Take the well-known concern about 'illegal migration,' which frames informal mobilities as rights violations. Such terms hide important aspects of these mobilities, from the social cushioning of informal migrants as permissible foreigners in 'host' societies to regular payment of under-the-table fees to state officials. A new state policy to fight illegal migration is routinely understood as perfecting state categorisations or improving regulations. But it is more revealing to think of it as a power bid - as some state actors' endeavour to shift a previously negotiated balance towards what they perceive to be their advantage.

The contributions to this book look at states from the perspective of people involved in (illegal) transnational flows. Our findings show that these people do not experience the state as a stable centre of authority. To them, the distinction between strong and weak states is not particularly relevant. Authoritarian, controlling states (such as China) are not capable of regulating behaviour and eliminating illegal practices any more than permissive, disorganised ones (such as Bangladesh). From their perspective, it is also difficult to pinpoint the limits of a state. At best, the state appears as a firm core of authority surrounded by more or less extensive grey areas in which actors share state and non-state features and straddle various systems of authority. At other times, people find it impossible to identify a firm core and the entire state structure appears to them as permeable, hazy and multiple, with individuals everywhere standing astride the state/non-state divide. These are the power brokers, regulatory bridge-builders, and creators and protectors of ecologies of licitness and legality. These actors are linchpins in the regulation of human behaviour under conditions of multiple 
authorities. As such, they must be at the centre of attention in studies of legality and illegality.

Finally, to people engaged in transnational flows, authority does not radiate outwards from centres of power: strong at the centre and weakening towards the periphery. The findings of our contributors do not support that view. It shows that to mobile people, authority is embedded in persons and objects and therefore is movable. Authority is not restricted to a particular territory and may materialise in unexpected places. For example, there is no necessary link between being territorially peripheral or geographically isolated and being free from state regulation (or, put differently, being excluded from the state). To people who are mobile, regulatory authority appears as a fluid property that can move about, expand and retract.

\section{Mobile Subjectivities}

The multiplicity of authorities within the nation-state not only shapes people's practices but also, and more crucially, forms their subjectivities. It would be expensive and delegitimising for states to shape the realities of its citizenry by a prevalent use of violence and sanctions (Foucault I979). Nation-building has been a primary task for every modern state. It is a project intended to create a collective consciousness and instil an identity that can socially unite a variety of people and turn them from subjects of a formal political organisation into participants in a normative project. The 'nation' can be seen as the modern state's key category. It is to the extent that states achieve the task of directing the subjectivity of their citizens towards the national that the modern state project gains stability, coherence and authority. Yet this task is never fully achieved.

All contributions in this volume show that states are unable to set the rules of the game. No state can make citizens completely internalise the rules, nor have them behave unthinkingly as the laws of the land command. This has partly to do with modern nation-states being relatively recent projects whose territorial grid has often been laid across more historical and evocative divisions. State authority is thus often pitted against a more socially accepted authority of regional, traditional, religious or ethnic elites. In addition, as Ford and Lyons demonstrate in the case of the border triangle between Indonesia, Singapore and Malaysia, and as Sur shows to be the case in the border between India and Bangladesh, customary pathways and historical trade routes may persist in spite of more recently erected state borders. The habitual practices of inhabitants in borderlands lead them to perceive the crossing of state borders, on a daily basis and without formal permits, as 
unproblematic. State officials, on the other hand, may well consider such practices to be a dangerous subversion of state sovereignty, economic insubordination or a potential security threat. But subjectivities may be negotiable, for example when state actors become deeply involved in facilitating unauthorised cross-border trade, or when they legalise 'smuggling'.

Mobile subjectivities are also evident in the emergence of new 'moral geographies' (Shapiro I994) as a result of a global weakening of the link between territoriality and sovereignty (Appadurai 1999; Sassen 2003). Some contributions indicate that people who undertake transnational mobility in search of a livelihood are unconcerned about the legality of their actions. They are guided primarily by life strategies that will improve their life chances. Citizens who feel that their state has failed to secure them a good life are indifferent to the law or other mores that flow from the state's national project. When a state habitually fails to deliver on its promises to care for its citizens, illegal but practical alternatives become more acceptable. As we shall see, Rohingyas in Saudi Arabia, Pakhtuns in Pakistan, borderlanders in Borneo, Chinese in Israel and many others have developed moral geographies that are not restricted to the state; they follow, to use Shapiro's term, the ethics of post-sovereignty.

In India, it is precisely the subjectivities of women that became the battleground in the process of drafting new emigration policies to the Gulf States. As Kodoth and Varghese illustrate, officials in India pushed for restrictions on the emigration of women because of the alleged risk of falling victim to sexual abuse by employers abroad. This protectionist approach was contested by some women for limiting their mobility and ignoring (abusive) conditions at home, but resonated with many others who still perceive the paternal role of the state as the guardian of women. Nonetheless, thousands of women chose to defy restrictive state regulations and emigrate to the Gulf through an informal but well-established channel (Pattadath \& Moors in this volume). The women then not only have to pay a much higher price for exercising their mobility, they also need to accept that their state will waive any responsibility for their situation abroad.

\section{Fashioning Licitness}

Millions of mobile people live their lives in the dim interface between legality and illegality. Rather than seeing this as a failure of the state system to assert itself, we should come to grips with the fact that reallife states are unlike the model state of much social theory. Even an 
authoritarian city-state like Singapore has never come close to this model, as Ford and Lyons make obvious in their contribution.

In this volume, we look critically at state categorisations of informal mobility and focus on the perspectives of mobile people themselves. Building on a recent proposal to distinguish between the realms of state authority (legal vs. illegal behaviour) and social regulation (licit vs. illicit behaviour), these chapters expand the discussion in a number of ways (Abraham \& Van Schendel 2005). Our case studies highlight how dynamic 'regimes of permissiveness' condition and sustain informal migration, and how transnational flows generate zones of licitness. Their creation - not as exceptions or surreptitious hideaways but as everyday spaces - is predicated on political negotiations for which the state is one partner among others, resulting in state agents being routinely and profitably embedded in wide-ranging networks of informal transnational brokerage. States are often important partners in these networks and active players in the ensuing politics of licitness.

For example, shifting discourses of citizenship in one state influence informal political practices in others. Emiratisation, a national policy which enabled qualified women citizens in the UAE to take up formal employment, led to a large informal migration industry involving migrants from all over South and Southeast Asia. As Emirati women found formal employment, a parallel economy of migration mushroomed, complete with fake sponsors, false contracts and counterfeit passports and visas. The resulting regime of permissiveness fashions licitness by turning a blind eye to the numerous infringements of formal rules, in the UAE and beyond, that facilitate this parallel economy.

Geographic proximity and trade links - such as those that exist in the borderlands of Indonesia, Singapore and Malaysia, or Bangladesh and India - generate further transnational regimes of permissiveness. These borderlands accommodate a vast range of informal flows, for example the widespread (but illegal) acceptance of the Singaporean dollar as a preferred means of exchange in the Riau Archipelago (Indonesia). In the Bangladesh-India borderlands, the gendered nature of the local 'regimes of permissiveness' is pronounced (Sur this volume). Here, women traders and commuters easily navigate the heavily patrolled border zone while men have to purchase border passages. State agents do not consider women's trans-border mobility and the small quantities of goods that they carry a risk to either Bangladesh or India. The presence of these women as permissible foreigners illustrates how certain categories of mobile people may partially escape territorial and exclusionist discourses. The local embeddedness of customs officials in Indonesia and border guards in India and Bangladesh helps to ease this circulation. Their behaviour illustrates how state actors are crucially involved 
in fashioning licitness out of citizens' transnational mobile practices that states categorise as illegal.

Zones of licitness often cushion the ramifications that a strict implementation of state policies implies for certain groups. In Taiwan, as Douw historically recounts, the Japanese colonial rulers attempted from I895 to redefine the status of a century-long migration flow of labourers from mainland China by treating them as foreigners and imposing on them the status of 'temporal migrant workers'. While the Japanese regime moved to exclude these 'temporal migrants' from state benefits and curtailed their permanent settlement, many in the local Chinese society viewed this as an illicit fiat. In practice, the new 'temporal migrants' quickly assimilated into the local Chinese society with whom they shared family, linguistic and other cultural ties. It is reasonable to assume that this development was known to, and even expected by, the Japanese rulers. As such, it represents a kind of 'controlled informality' (Kodoth and Varghese in this volume), whereby a zone of licitness is used to accommodate a balance between the economic and political goals of the regime and the social dynamics that shape the realities of those living under the state.

\section{The Chapters}

In Chapter I, Barak Kalir expands the 'illegal but licit' analytical framework as advanced by Abraham and van Schendel (2005) by drawing attention to cases in which state authorities act illegally, yet their illegal actions are considered licit by the majority of citizens. Kalir elaborates on the precarious situation of legal Chinese migrant workers in Israel, who are forced out of their legal status by systematic exploitation by local employers and the endemic lack of protection of their rights by Israeli authorities. Migrant workers who lost their status are then captured and imprisoned by the Israeli Immigration Police and then deported back to their countries of origin. These processes of detention and deportation are often pursued in clear violation of migrants' rights under Israeli and international law. While such violations have been made public by journalists and non-governmental organisations, they fail to arouse public opinion against such practices; to the contrary, it appears that the harsh approach adopted by the Israeli authorities vis-àvis undesired migrants is endorsed by the majority of Jewish citizens. It is then argued that non-Jewish migrant workers in Israel cannot be considered worthy political subjects (albeit temporary) in the eyes of many, who then accept the illegal actions of the state against them.

Chapter 2 by Oskar Verkaaik, Sarfraz Khan \& Samina Rehman expands the focus on state authorities by examining the case of tribal 
areas in northwest Pakistan, where the state has given up its formal authority to so-called tribal customary law. The chapter explores the growing dissatisfaction among many in the tribal areas, who wish to draw on alternative sources of authority to challenge the notion of tribal culture on which this formal 'state of exception' is based. The authors explore three discursive alternatives: I) Islam, 2) a redefinition of tribal culture in terms of Pakhtun nationalism, and 3) references to modernity and the notion of universal civilisation. It is argued that these discursive alternatives transect the analytical distinction between licitness and legality. Each is a moral language, derived from religious, cultural and civilisational traditions. What is perhaps unique in the case of the tribal areas is the extent to which contesting discourses of licitness express themselves in a legal language; each discursive alternative prescribes a specific legal system: I) the shariat, 2) a redefinition of customary law, and 3) universal human rights or the Pakistani constitution respectively. This, the authors maintain, highlights the particularities of the Pakistan context, where the state's right to formulate, exercise and defend its rule of law has been historically fundamentally challenged.

In Chapter 3, Diana Wong and Pok Suan Tan document the hypermobility of a refugee population from Burma known as Rohingyas in various countries throughout the Muslim world. Rohingyas have been recognised as 'persons of concern' by the United Nations High Commissioner for Refugees (UNHCR) and should, in theory, be protected under a universal regime of human rights. However, in practice, their situation as refugees is contingent on the makeup of formal state policies, a cultural notion of 'Muslim hospitality', the social attitudes of multiple local communities and the spread of transnational family networks. Given changing economic and political circumstances, states like Bangladesh, Saudi Arabia, Pakistan and Malaysia can revoke their recognition of Rohingyas as refugees and move to categorise them as 'illegal immigrants' who should be deported. While the goal for Rohingyas is to receive formal status from a state where they can stay and not fear deportation, their precarious situation forces them to become highly mobile and cultivate an extensive transnational network rather than a sense of belonging to a territorial state.

Chapters 4, 5 and 6 focus on borderlands and the production of licitness, the tensions between the regulative power of the central government and local authorities, and flows of people and goods at the margins of the state. Michele Ford and Lenore Lyons elaborate on the case of the Riau Islands, Laurens Bakker and Jay Crain on Nunukan, the northernmost district of Kalimantan, and Malini Sur on the IndiaBangladesh borderlands. All these cases testify to the important but often ignored fact that in the order of the world political organisation, communities come before states, as David Ludden (2003) argues. 
Investigations of current transnational practices show how borderland communities still straddle a geographic, social and economic region that was later divided between two or more nation-states. Since the regional cohesion precedes the more recent state division, social, ethnical and kinship networks still prevail in these regions, and certainly in the perceptions of the inhabitants there. Moreover, local forms of authorities as well as economic and social practices seem to be guided - still more by social understandings and moralities than by state law.

In Chapter 4, Ford and Lyons question the analytical accuracy and value of describing the market that has developed in the Riau Islands as one of smuggled goods when it is actually done in broad daylight and often with the consent of local officials (for a bribe), who exercise autonomy in controlling the local economy. Being fully imbricated in the illegal but licit trade across the straits, the local officials actually set themselves, rather consciously, against the aim of the central government to enforce a rearrangement of the internal Indonesian trade lines. In the Riau Islands, the local economy, which functioned for generations on trade across the straits, was disrupted by the successive establishment of modern nation-states: Singapore, Indonesia and Malaysia. People on the Riau Islands were obliged to integrate economically into the national economy of the new state of Indonesia, at the expense of their traditional trade in the region. This is not an easy adjustment, as commodities that now have to reach the Riau Islands from Java are more expensive, often arrive defective, and are generally considered by local people to be of a lower quality. Not surprisingly, a flourishing market of smuggled goods has developed on the Riau Islands in recent decades.

The district of Nunukan shares a similar history of trade with partners, far beyond what has become the state of Indonesia. The area is located on the border with Malaysia, and has ties with the Philippines as well. After the fall of Suharto, authority within the Nunukan district spread between the local business and state elite and the traditional adat and religious Christian leaders, who each looked to fortify their social authority. The stride for authority, as Bakkar and Crain consider in Chapter 5, has never been decided in favour of one side. What emerges is a delicate balance between the letter of the law and the local traditions. Local police agents embody this balance as they oscillate between upholding state authority and giving in to the local 'ways of doing things', which means that they often have to disregard the formal laws. The border, rather than effectively separating the two countries, simply offers new economic opportunities that to a large extent depend on trans-border connections among families, ethnic groups and business partners. Yet the terrorist bombings in Indonesia have given rise to enhanced border control for those passing from Malaysia. This has 
strengthened the formal authority of the Indonesian state officials and weakened the traditional authority of local religious and ethnic leaders. At the same time, illegal logging by teams invading Indonesian territory is occurring regularly, not hidden from the eyes of local authorities but rather with their compliance.

Like the borderlands of Singapore, Indonesia and Malaysia, flows of people and goods are guided by shared histories in the borderlands of Northeast India and Bangladesh. Sur follows the arrival and departure of Bangladeshi Garo adivasi ('indigenous') traders and daily wage labourers to Domachi, a border town in Meghalaya, Northeast India. She posits that undocumented trans-border mobilities, especially in regions where borders divide similar societies, are located at the intersection of sovereign violence and social legitimacies. She explores these intersections by following bodies in motion, and bodies that are selectively intercepted and deported at the heavily patrolled and militarised India-Bangladesh border. Set against this violent border, Sur's contribution compares the crossings of women traders and men labourers and complicates discussions on questions of access to borders and borderlands. She departs from and challenges the framing of militarised borders as spatially and socially liminal, and especially, as sexually predatory zones for women.

Chapters 7 and 8 present case studies on women's autonomous migration, arguing that state protections in India translate into restrictions by invoking the rhetoric of 'risk'. Bindhulakshmi Pattadath and Annelies Moors contest the protectionist move by the Indian state to restrict the transnational mobility of female migrants under inflamed rhetoric of the risk they run of falling victim to sexual abuse abroad. The authors show how formal restrictive policies rarely manage to prevent women from undertaking what they perceive to be the best coping strategies for securing a better life for their families. Female migrant domestic workers from India exercise agency in shaping informal migration routes and in drawing on a set of illegal but licit institutional arrangements that effectively bypass or elude formal state procedures. For example, transnational networks involving state agents in India and the UAE mediate the physical act of 'pushing' by which domestic workers negotiate passage at Dubai airport. Thus, 'pushing', often becomes a norm in enabling migration rather than an exception, as women illegally bypass emigration clearance rules with the help of state agents at airports. These informal ways of arriving in the UAE do not impair women workers from becoming 'legal migrants' after procuring working contacts. Women domestic workers construe their actions to be socially acceptable and present their multiple dealings with two nationstates and various actors involved in the process of migration as agentive functioning. The authors stress that by ignoring or misrecognising 
the genuine problems of female migrants who operate under structurally inequitable transnational migration regimes, state actors and formal policies often aggravate the already insecure position of women.

In Chapter 8, Praveena Kodoth and V.J. Varghese take on the protectionist migration regime of India as a case in point to show how states exercise formal authority in restricting the transnational mobility and life opportunities of women. The authors argue that, for the Indian state, marriage is a defining feature for regulating women's migration. There is both a sense of shame over women's emigration for informal work such as domestic work and a tendency to shrug off responsibility for their well-being. Women's transnational migration is discussed at best through the lens of human trafficking, and at worst through a regime of legal restrictions. Thus, while laying the foundation for a gendered conception of sovereignty, the state's interference in women's migration for overseas domestic work has functioned as a double-edged sword of protectionism and permissiveness. On the one hand, it has controlled the movement of women by imposing restrictions, while on the other it has encouraged them to access emigration through the use of informal/illegal processes. The authors argue that state agents become integral to the creation of a 'controlled informality' in the emigration process that stigmatises paid domestic work and forces poor women to seek informal/illegal channels of emigration. In line with feminist critics, Kodoth and Varghese astutely show how national legislations easily and incorrectly conflate women's migration with human smuggling and moral panic.

Chapters 9 and ro are concerned with the regulation of Chinese migration flows. In Chapter 9, Leo Douw traces the management of the flow of Chinese migrant workers from mainland China to Taiwan to the period under Japanese colonial rule. His historical account shows how state categories often fail to ordain the population because social dynamics work to subvert these categories in practice. For centuries, Chinese from mainland China enjoyed full rights when crossing the straits to settle in Taiwan, as they were subjects of the Chinese empire. Yet, when Japan ruled over Taiwan, it assigned the label of huaqiao to Chinese migrants in order to mark them as temporary migrant workers that were excluded from state benefits and political influence. Given that the overwhelming majority of the population in Taiwan is ethnic Chinese, the division between the local majority and the new group of huaqiao was no more than a formal one. Through longstanding family and business networks, Chinese newcomers - many of whom had made their way into Taiwan illegally - quickly assimilated into Taiwanese society. The attempt of the Japanese regime to prevent Chinese migrants from developing a sense of political and territorial belonging to Taiwan backfired when political contestation of the Japanese rule 
fermented from the I920s onwards. Huaqiao in Taiwan collaborated with the government in mainland China to undermine the Japanese regime, not least because their ascribed status as huaqiao implied a sojourn status and fixed their loyalty with mainland China.

In Chapter Io, Minghuan Li also historicizes the emergence and development of transnational migration brokerage in China. Starting with an account of the situation from the late Qing Dynasty to the early period of the People's Republic of China, she historically traces migratory flows from China to the rest of Southeast Asia and beyond. What Li shows is that the pattern of brokerage under or beyond the patronage of the state is rooted in the historical management of emigration flows from China. Importantly, Li stresses that although many of the early migratory flows were fraught with slavery practices, they were often seen less negatively than 'objective' commentators described them. Although many indebted labourers endured difficulties as workers abroad, they eventually managed to establish themselves economically, and at times also ventured into business - building on their transnational connection to their hometown in China. To the extent that labourers managed to survive hardship and attain an economically advantageous position, they would see and treat the involved brokers in a not-so-negative fashion. In post-Mao China, labour exportation has become a huge business and has gradually moved from the monopolistic hands of public companies to the hands of private or semi-public ones. Li depicts the illegal but licit practices of brokerage in modern China, focusing empirically on those who make their way to Israel and the US. By focusing on the narratives of migrants who are involved in the process of 'smuggling', Li convincingly shows that brokerage in China is being evaluated not according to its formality but according to its effectiveness. She details the case of 'Sister Ping' in the US, a settled Chinese migrant who operated a wide transnational network for bringing Chinese workers into America. Ping, who can formally be seen as a human trafficker and who was eventually convicted on these grounds under the law, was a heroine in her hometown and her fame was spread throughout China for being a trusty broker who could help those who wish to emigrate, and for a fair price as well. 



\title{
1 Illegality Rules
}

\section{Chinese Migrant Workers Caught Up in the Illegal but Licit Operations of Labour Migration Regimes}

\author{
Barak Kalir
}

This chapter explores the immigration of Chinese migrant workers to Israel in light of the 'illegal but licit' analytical framework as advanced by Van Schendel and Abraham (2005). The 'illegal but licit' analytical framework conceptualises a useful distinction between the il/legal and the il/licit, in order to enable us to grasp better, and talk about, what really happens on the ground - in, across and under the formal authority of nation-states. The 'illegal but licit' framework broadens and forces our analysis to include flows and actions that are located in a zone where a mismatch exists between the state's formal political authority and non-formal social authority. ${ }^{\mathrm{I}}$

The first aim of this chapter is to examine the immigration flow from the viewpoint of Chinese migrant workers, who must go through numerous informal and illegal stages in the process of recruitment and employment. Migrants regularly perceive their own actions as well as those of recruitment companies and employers to be licit. Yet, the licitness in this case is often the product of a culturally infused confusion or plain ignorance regarding the obliging legal systems in China and Israel. Notably, instead of there being an institutional attempt to offset the confusion of migrant workers, this confusion is being systematically compounded by deliberate manipulations of Chinese and Israeli recruitment companies and employers.

The second aim of the chapter is to examine closely the work of the formal authorities in China and Israel. As I shall demonstrate, the two states choose to accommodate and turn a blind eye to the informal and illegal dealings of private and public companies involved in the recruitment and employment of Chinese workers. At times, states also act against migrant workers using illegal methods. I therefore argue that our understanding of the role of the state within the 'illegal but licit' framework should not be confined to policymaking and the fixing of legal boundaries but instead should include a treatment of the executive powers of states within the field of immigration. While the notion of 
licitness helps to clarify the meaning of an illegal action that is socially accepted by the people who engage in it, we need to broaden the scope of the 'licit' to include the peculiar situation in which state authorities act in illegal manners according to the national law as well as international conventions, but these illegal actions are perceived to be licit by a majority within the national population.

\section{Chinese Immigration to Israel: A Short History}

A series of global and geopolitical changes in the late I980s and early I990s prompted Israel to engage, for the first time in its history, in the importation of non-Jewish temporary migrant workers. The first Palestinian intifada in 1987 signalled the end of Israel's ability to rely on an uninterrupted supply of cheap Palestinian labour from the Occupied Territories. The disintegration of the Soviet Union in 1989 and the lifting of the Iron Curtain led to the immigration of nearly one million Jews into Israel in the early I990s. Having to provide Jewish newcomers with employment and badly needed accommodation, Israel attempted to substitute Palestinian workers with Jewish immigrants. However, for reasons that pertain largely to the status of jobs in the Israeli labour market, most recent Jewish immigrants from the former Soviet Union declined the jobs that had previously been occupied by Palestinians (Kalir 2010).

Facing an acute shortage of unskilled labour, a potential economic recession and massive pressure from the powerful lobbies of Israeli employers, the state of Israel resorted in I993 to the importation of migrant workers. Migrant workers have been recruited from countries in Asia (e.g. the Philippines, Thailand, Nepal, India and China) and Eastern Europe (e.g. Romania, Bulgaria and Moldova), mainly for jobs in the agricultural and construction sectors. By 1996 , there were already I0०,000 temporary migrant workers in Israel, which comprised five per cent of the total Israeli workforce (CBS 2002). Work visas for migrant workers were issued for a maximum period of five years, after which workers were obliged to leave the country.

In I992, Israel and China officially established diplomatic relations. Soon after, Chinese migrant workers started reaching Israel in increasing numbers (see figure I). The recruitment of workers from China should be seen in a broader context of the rapidly growing economic ties between the two countries. According to the Chinese embassy in Tel Aviv, the Sino-Israeli bilateral trade increased from US\$ 50 million in 1992 to US\$ 3 billion in 2005 , and more than 800 Israeli companies are currently doing business in China. ${ }^{2}$ 
Figure 1.1 Number of Chinese migrant workers reaching Israel (in
thousands)

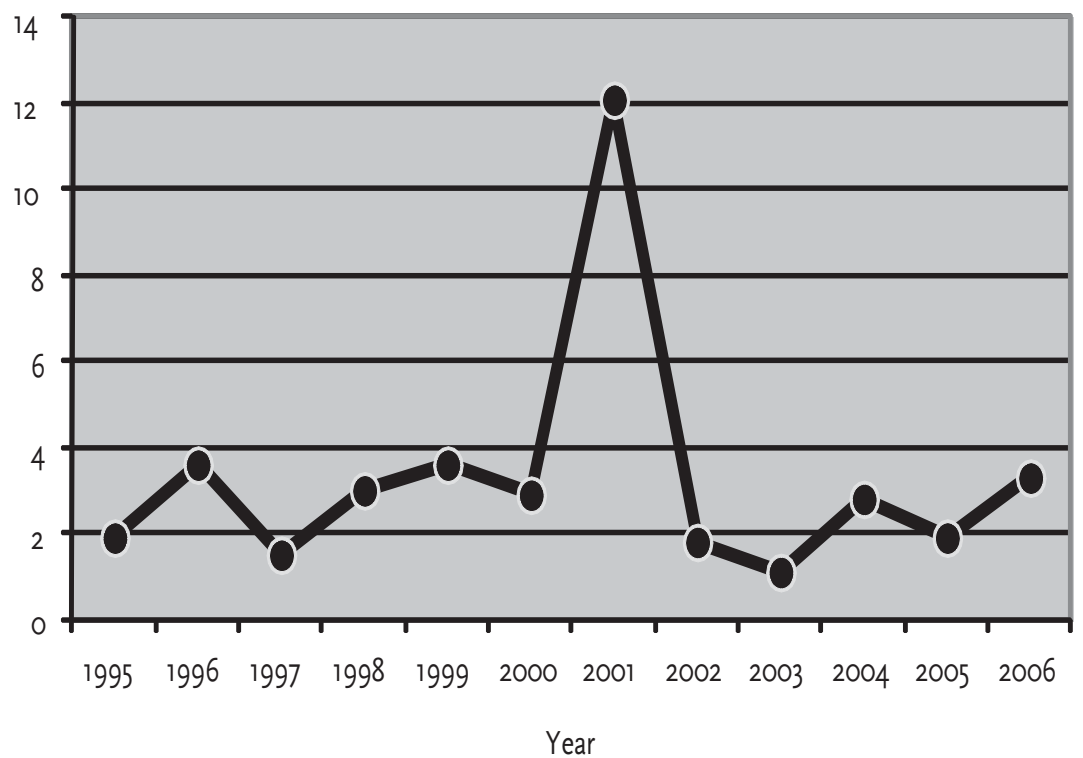

From an indicative rather than a representative sample of 40 Chinese workers that I interviewed, it appears that most of them come from a poor economic and educational background; they usually earned a premigration salary of US\$ IOo per month from work in construction or agriculture, and they had around seven years of education, commonly quitting school at the age of 15 and beginning to work for their household's income. Indeed, the average monthly disposable income per person in the provinces from which migrants reach Israel were in 2006 as follows: Hubei US\$ 90, Anhui US\$ 95, Hebei US\$ I05, Fujian US \$ I30, and Jiangsu US\$ I35 (Israeli Embassy in Beijing, July 2006). In Israel, Chinese workers can earn between US\$ 800 and US\$ I,200 per month if they work according to standard contracts in the construction sector. This means that an average ratio of around i:8 exists between workers' salaries in China and the salaries they can earn in Israel (see also $\mathrm{Li}$ in this volume).

Chinese workers in Israel are predominantly employed (around 9o per cent) in the construction sector. The other ro per cent are employed in factories, agriculture and caregiving for disable people. ${ }^{3}$ Chinese workers were initially recruited from villages across the southern province of Fujian, but in later years, recruitment has spread to other provinces like Jiangsu, Anhui, Hubei and others. 
Most Chinese workers (around 8o per cent) are in the age group of 30-44 (CBS 2006), and many of them are married and have children. This latter fact is not a coincidence but rather a deliberate policy of the Israeli government, as it is meant to prevent the possible settlement of workers in the country. It is strictly forbidden for migrant workers to bring over their families to Israel, and the separation from their families undoubtedly wears Chinese workers down emotionally. The Spring Festival, for example, has become known among some Chinese in Israel as 'The Red Eyes Day', referring to the many tears they shed during this festivity while talking on the phone with their family members in China. Some of the migrant workers I met used to count down the years, months and even days to their expected return to their family in China.

As a fact, Chinese workers do not settle down in Israel. This has largely to do with the restrictive Israeli policy and the practical impossibility of receiving Israeli residence (see also Li 2006). Some Chinese told me that, had they been able to receive permanent residence and bring their family to Israel, they would have considered settlement. A few unmarried Chinese workers in their late twenties told me that they thought about marriage to an Israeli woman, which is the only way for them to receive permanent residence in Israel. Yet most interviewees voiced what they perceived to be the practical unfeasibility of marrying an Israeli; as one young Chinese worker bluntly put it: 'Israeli women don't like Chinese men'. And in fact, to the best of my knowledge, there are only two registered mixed marriages between Chinese workers and Israeli women. ${ }^{4}$ And since very few Chinese female migrants reach Israel, the chances for male workers to get involved in a romantic relationship with Chinese women and establish a second household in Israel are low.

Other reasons that Chinese workers mention for not desiring settlement in Israel include the language barrier, the distinctive physical 'otherness' of Chinese in Israeli society, and the fact that their economic future in China is seen preferable to the one they can expect in Israel. In the words of one migrant worker: 'In Israel I can earn good money but I can never do anything else but work in construction. With the money I earn here I can maybe open my own business or manage a team of construction workers in China. I will never work there [in China] like I work here'.

The lack of possibility and/or desire to settle down in Israel led most Chinese migrants not to value integration into Israeli society. ${ }^{5}$ Chinese migrants maintain very little social contact with other Israelis except for their employers. When I asked a few of them about it, they referred to the language barrier as well as to a general lack of interest, beyond the initial anecdotal one, on both sides. Here is how one Chinese worker 
summarised it: 'Israelis see us as workers. They can be very nice to you when you work for them but they will not even recognise you if they see you after some days on the street. But it's ok, we come here to work and go back home'.

Chinese migrants who were forced into illegality or knowingly chose to become undocumented (as I will explain later) always eventually decide to leave Israel. This is in contrast to the life strategies of undocumented migrants from Latin America and Africa, who choose to settle down in the country (see Kalir 2005, 2010). As one Israeli activist in a local NGO that deals with undocumented migrants told me: 'On the spectrum of perspectives among illegal migrants in Israel, Chinese represent one end - that of the migrants who are totally busy with saving their money and investing it in China and not in their present or future position in Israel'.

\section{Ubiquitous Informality: The Recruitment of Migrant Workers in China}

As several scholars have documented, the transition in China from a planned economy to a market economy has led, among other things, to a proliferation of employment agencies, recruitment companies and labour export companies that deal with the emigration of Chinese workers (Biao 2003; Wu 2005; see also Li in this volume). These new companies are the offspring of the former PRC aid missions to allied countries, which were performed by state companies and 'honorary volunteers' (Li 2004) - a Chinese euphemism for project workers who worked abroad for little or no money.

Chinese labour companies nowadays operate under the authorisation and supervision of four different ministries. This bureaucratic complexity at least partly accounts for the fact that 'labour export from China seems not well regulated, despite the fact that most labour export companies are state-owned' (Biao 2003: 34).

Notwithstanding the federal bureaucratic jumble, labour export in China is by no means confined by regulations that are drafted by the central government in Beijing. Firstly, since the I980s, the central government has gradually lost its monopoly on regulating the emigration of workers. Local governments in different provinces now exercise a degree of freedom in articulating and carrying out their own policy with respect to emigration. Those local governments that are more worried about demonstrating economic growth view emigration positively and actively facilitate it as a means of creating a flow of remittances and raising the local standard of living (Thunø \& Pieke 2005). 
Secondly, authorised companies at the federal as well as provincial and local levels do not tell the full story of emigration from China. In post-Maoist China, the right to emigrate has been increasingly allotted to all Chinese citizens, regardless of their personal or institutional position. The strong desire among the Chinese to emigrate has given impetus to a flourishing informal 'migration industry' (Harris 1996). This migration industry consists of private 'entrepreneurs' (known as snakeheads) who arrange for people to emigrate in exchange for payment. ${ }^{6}$ As Biao (2003: 24) reports, irregular emigration services are 'sometimes regarded as local development strategies, and are therefore accorded a certain degree of legitimacy'. In fact, 'emigration companies that drive much of the emigration ... operate in full view of the authorities and are often connected to state-owned enterprises' (Biao quoted in Pieke 2005: I4).

Only a thin dividing line can thus be drawn between the legal work of authorised companies and the illegal work of the informal migration industry in China. In some regions, like in coastal central Fujian, 'individual officials of the government ... had been involved in the illegal emigration business already from the early I980s' (Pieke 2005: I3). In fact, as I shall describe next, from the perspective of many Chinese migrant workers in Israel, no such line can be drawn at all.

Formally, all Chinese workers who go to Israel pursue a legal immigration channel according to the regulations. ${ }^{7}$ They all receive a passport with a work visa issued by the Israeli embassy in Beijing specifying the name of the Israeli company and the job for which workers are recruited. Israeli companies that recruit workers in China (around 40) must always collaborate with authorised Chinese recruitment and labour export companies (around 30). ${ }^{8}$ Indeed, from a purely formalistic perspective, one can conclude that the recruitment of Chinese workers is processed in an orderly fashion by Israeli and Chinese authorised companies, and in full compliance with formal procedures and state institutions.

Yet a closer examination of the process reveals a distinctively different picture. It is a picture of a process that is fraught with informality and illegality but which nevertheless receives the legal cachet of both the Israeli and Chinese states at the final stage. From this closer examination, the formalistic character of the process appears to be a sheer façade.

The most striking informal side of the process is the illegal fees that Chinese workers are being charged by Chinese recruitment companies for the opportunity to work in Israel. The Israeli Employment Law (1959) forbids Israeli companies or individuals - both in Israel and abroad - to charge a fee for the workers they provide to Israeli employers. ${ }^{9}$ The Chinese law, however, does not directly address this issue; 
while there is no mention in the law that charging fees from recruited workers is legal, there is equally no prohibition of such a practice.

In practice, Chinese workers must all pay recruitment companies an informal fee, which has been rising consistently from around US\$ 5,000 in the late I990s to around US\$ I0,000 in the early 2000 s and up to US\$ 30,000 in 2010 (see also Li in this volume). To pay the informal fee, most Chinese migrants take loans from one or all of the following sources: relatives, friends, banks and usurers. Almost all Chinese migrants depend, at least partly, on loans from usurers who charge an interest rate of one to three per cent per month. The willingness of the Chinese to pay high fees undoubtedly reflects their strong desire to emigrate to Israel. $^{\text {IO }}$

The informal fee is regularly paid 'under the table', although it is partly used to cover formal expenses such as flight tickets, medical exams, visa application and other paperwork. The largest part of the fee is taken by the different recruiting agents that stand between potential migrants and their desire to work abroad. Nowadays, most potential migrants learn about the opportunity to work in Israel from their relatives or friends who had been there (to a lesser degree, they hear about it from advertisements in newspapers and from posters in the streets). Potential migrants must first make contact with a recruiting agent, who usually meets them in their village. The recruiting agent usually asks potential migrants to pay a 'registration fee' of around 20 per cent of the total informal fee. This 'registration fee' is meant to demonstrate to the agent that the would-be migrants are sincere about their intentions and can raise the money.

Next, the recruiting agent puts potential migrants in touch with recruitment companies that are based in the capital of the province or other major cities. These provincial recruitment companies might not be authorised labour export companies but they have close ties with authorised companies, which are often based in Beijing. It is mostly provincial companies that directly collaborate with Israeli companies for receiving allocations of work permits for Chinese migrants. In Israel, these semi-authorised provincial companies are also known as 'dealers'. Israeli recruitment companies work with a number of Chinese 'dealers' that recruit workers and charge them the informal fee. Shares of the fee are then given to both the Israeli company and the Chinese stateauthorised labour export company in Beijing.

The above is only a sketchy depiction of the recruitment process, which might include more mediation stations before its successful completion. The multiplicity of mediation stations not only inflates the informal fee but also increases the risk that migrants fall victim to criminal schemes or tactical manipulations. I heard several stories about Chinese who paid the 'registration fee' to recruiting agents who then 
disappeared with the money. Others who already paid the full fee were told that the process was stalled at a certain mediation station and that it would cost more money to get it through (at times even as much as US\$ 3,000$)$.

The strong desire among the Chinese to emigrate leads in some areas to competition among many people for a limited number of work permits. This not only allows recruitment companies to push informal fees higher, it also forces potential migrants to 'become friends' with senior managers in recruitment companies. The following story illustrates what 'becoming friends' translates into in practice.

$\mathrm{Lu}$ and Shen come from the village of Shentan in central Fujian. In 200I, they were put in touch with a recruiting agent in their village who promised to arrange Israeli work visas for them for US\$ I2,000 each. After paying the agent a registration fee of US\$2,000, they were instructed to raise the rest of the money within a month while their application was being processed by the provincial company. Having managed to raise the full amount, they contacted the agent who informed them that the provincial company received a reduced number of Israeli work visas, and therefore $\mathrm{Lu}$ and Shen would have to wait their turn patiently. Some weeks later, the agent told them that the 'big boss' from the recruitment company in Fuzhou was coming to the main town in the county, and that it would be wise for them to invite him for dinner and see to it that he had a 'good time'.

The two friends had little choice but to accept the advice of their agent, as $\mathrm{Lu}$ realised all too well: 'There were too few visas and if we wanted to get one it was not enough that we were willing to pay the fee. We needed to become friends with the big boss, you know, drinking beer together, eating. Then he knows you personally and when the next visa comes in he will think of giving it to you'.

The 'big boss' arrived in town with his entourage, and the dinner in a private room at a fancy restaurant cost US\$ 800 . Lu shared with me his astonishment at the luxurious dinner: 'I've never before in my life been to such a restaurant'. The two friends also offered the big boss a massage in a spa and a night in a suite at an expensive hotel. The expenses that the two friends paid reached a total of around US\$2,000. 'Sometimes the boss will later deduct some of these expenses from the fee you pay, but sometimes not. In our case, we got visas two months later and the boss also gave us a discount of US\$ I,000 from the price'. Lu seemed rather content with the deal they had managed.

The informal and illegal dealings that Chinese migrants experience are also evident in the process of signing a working contract. According to Israeli regulations, migrant workers must sign a detailed contract before they reach Israel and receive a copy of it in their own language. Israel formally requires that both Israeli and Chinese recruitment 
companies comply with these regulations as a condition for receiving work permits. Yet no effective enforcement of this regulation takes place. Chinese recruitment companies take advantage of the fact that many Chinese workers are illiterate and/or desperate to emigrate; recruitment companies thus offer no written contract to migrants who are too afraid to insist on it or are ignorant about their right to a contract. From a survey conducted by Israeli NGOs among 43 Chinese workers, it was revealed that $\mathrm{i} 2$ per cent of them never signed a written contract, and among those who did sign a contract, 45 per cent never received a copy of it (Hotline for Migrant Workers and Kav La'Oved 2007: 22).

The Israeli regulations regarding the signing of contracts could have been easily enforced, for example, by the Israeli embassy in Beijing before the issuing of visas for Chinese workers. However, as the Israeli Consul in Beijing told me: 'I never know what kind of contracts they sign and what is written in them. For me, such contracts do not exist'. ${ }^{\text {II }}$

Based on my own interviews with Chinese workers in Israel, it appears that the only meaningful contract they sign in China is with the 'dealer' (the provincial, semi-authorised recruitment company). This contract usually specifies the responsibility of migrants to work only for the Israeli employer that is indicated in their contract. Some contracts also mention the liability of the recruitment company towards migrants in case of a premature deportation from Israel. As will be explained in detail in the next section, it is often the case that migrant workers lose their legal status soon after their arrival in Israel. If then caught by the Israeli Immigration Police and deported back to China, these migrants find themselves in the impossible position of trying to pay back the loans they took for paying the informal fee to recruitment companies. The contract they sign with 'dealers' is therefore a kind of 'insurance policy' against deportation. As one migrant, Zhoung, explained to me: 'If you are deported soon after you reached Israel and the company doesn't give you back at least part of the fee, you are a dead man'. When I wondered if Zhoung meant 'dead' literally, he explained in more detail:

If you paid US\$ I5,000 and you were deported after three months, you can never pay back all the people from whom you borrowed money. They will then come to your house every day to ask it back. If you own a house, they will take it from you and sell it. If you have children, they will take them from you and sell them. They can also bring mafia people to threaten you with injuries or even death. That's why you need a guarantee from the company that you'll get back some of the money in such a case [of deportation]. If they give you back US\$ I०,০০০, then you only 
need to pay back US\$ 5, 0oo. Let's say you saved some money in the three months in Israel, so with a lot of hard work in China you'll be able to pay back the remaining US\$ 2,000-3,000.

I then asked Zhoung what happens to all those migrants who have not signed this type of 'insurance policy' with their recruitment company. Zhoung shared with me his knowledge of such cases:

I know of people who were deported back to China but never went back to their village. They stayed in Beijing or Shanghai to work like crazy just so that they can send some money back to their families. Sometime they will secretly call their family and tell them to come to Shanghai, and then they will never return to the village again. Other people who returned to the village went to the big boss in the city and threatened that if he wouldn't pay them back some of the fee, they will kill him or do something crazy.

I interrupted Zhoung, saying that that 'big bosses' surely have bodyguards who can probably inflict more harm on a violent migrant than the other way around. Zhoung quickly agreed:

Of course, in the office you can do nothing. But maybe on the street when he walks with his family, or at night in his home. He can't be all the time with guards around him. And you have nothing to lose. That's why I say a 'dead man'. You might be alive, but owning so much money it is like you are dead. So the boss knows you can do something crazy and it is better for him to pay you back some of the fee. He has millions, maybe even billions. For him, US\$ Io,০oo is nothing. So he'll say: 'here, take the money and go away'.

Most Chinese companies never inform recruits about the exploitative contractual relation to Israeli employers, who can fire them at any given moment and thereby instantly invalidate their legal work visa (see next section). Chinese companies also often promise their recruits - albeit never in written form - an employment period of three to five years in Israel. This is a false promise because according to Israeli regulations, the number of migrant workers that employers are authorised to hire is revised each year. Israeli employers can therefore never guarantee migrant workers a period of employment that exceeds one year.

As we can see, the legal and illegal aspects of arranging emigration from China to Israel are completely enmeshed. Legal procedures might be carried out by unauthorised agencies, while illegal procedures (like 
charging informal fees or getting paid for having a 'good time') might be performed by officials in authorised companies. Moreover, Chinese companies that process the immigration of workers to Israel (and elsewhere) in this partly illegal and overwhelmingly informal fashion consider their dealings to be licit. They mostly carry out their business openly and often with full awareness (and often also with the informal approval and cooperation) of state authorities.

\section{Ubiquitous Illegality: The Employment of Chinese Migrant Workers in Israel}

The state of Israel implemented a highly restrictive importation scheme, allegedly to ensure that migrant workers would never settle down in the country. According to this scheme, work visas are issued for a maximum period of five years, after which migrant workers are obliged to leave Israel. In Israel, migrant workers are restricted to work only for a designated Israeli employer whose name appears on their work visa. If, for whatever reason, migrant workers cannot be employed by their exclusive employer, their visas are instantly invalidated. It does not matter whether Israeli employers arbitrarily decide to terminate the contract with migrant workers or whether migrant workers decide (often after they were exploited) to work for other Israeli employers: the consequence is always the same, that is, an instant loss of the migrant's legal status. This stringent system, which effectively binds migrant workers to a particular Israeli employer, has become publicly known in Israel as the 'binding arrangement', and it resembles the kafala system that is in place in the Gulf States (see Gardner 20Io; Pattadath \& Moors in this volume).

The 'binding arrangement' is to the disadvantage of migrant workers, who are deprived of all bargaining power in the local labour market. Even more disturbing is the way in which this 'arrangement' hands employers the power to systematically exploit their migrant workers. Being able to threaten their workers with dismissal, many Israeli employers regularly exploited migrant workers in different ways (on the different forms of exploitation, see Kav La'Oved I998, 2000; Schnell 200I).

The fear of being dismissed leads many migrant workers to endure severe working conditions and harsh exploitation. Nevertheless, tens of thousands of migrant workers end up losing their legal status, often without even being aware of it. For example, Israeli employers must renew the work visas of their migrant workers every year. The renewal process involves a fee (of around US\$ IOO in 2005) to be paid by employers to the Interior Ministry. Without ever informing their workers, some employers decide to save on the cost of renewing visas, thereby 
rendering their workers' status illegal. ${ }^{\mathrm{I2}}$ The reader might rightly wonder here: after undergoing the process of bringing workers from China (and other countries) to Israel, how could Israeli employers so easily decide to dismiss them or not renew their visas and thereby run the risk that the police would deport them? To answer this question, we must return to the role that recruitment companies play in the importation process.

Employers in Israel must use the services of Israeli recruitment companies that specialise in importing workers. Recruitment companies obviously save employers time and trouble, but they also pay employers kickbacks for the 'right' to provide them with migrant workers. As mentioned in the former section, Israeli companies work together with foreign recruitment companies ('dealers'), which do the actual recruitment abroad and share the collected informal fees with their Israeli 'partner'. In the early 2000 s, Israeli recruitment companies were making an estimated average profit of US\$ 3,000 for each migrant worker they provided to Israeli employers (State Comptroller 2003: 649). From my own sources, I learned that in the case of Chinese workers, Israeli companies received in 2005 around US\$ 10,000 for each worker who reached Israel.

Encouraged by these kickbacks, many Israeli employers apply with the Interior Ministry for more work visas for migrant workers than they actually need. Some employers with superfluous migrant workers began to 'sell' their workers to other employers who were not entitled, according to the state's criteria, to an allocation of migrant workers. The 'selling' of workers is strictly illegal under Israeli law and amounts to human trafficking. It also leads, of course, to migrant workers losing their legal status, as they must work for someone other than their exclusive employer. If not able to 'sell' their workers, Israeli employers will simply dismiss them, sometimes even days after their arrival in Israel.

Two questions are pertinent here: first, why have Israel and China not taken action against such a failing labour importation system and the related illegal schemes that it fosters? Second, why haven't Chinese migrants learned their lesson and stopped (paying high informal fees for) coming to Israel? I will first answer the second question, which will also shed some light on a more inclusive discussion of the role of states in the next section.

There are several factors that explain the continued flow of Chinese workers to Israel, despite the exploitative conditions to which they are subjected. First, most Chinese workers who were exploited and deported still managed to earn enough money to pay back their debt and even save some capital. The absolute number of Chinese workers who lost all their investment in immigration to Israel is not high, and as one Chinese 'dealer' explained to me: 'China is big. It is not as if 
when some workers from a county in Fujian were cheated that everyone in China knows about it. Even in the same province, in another county people might still know nothing about Israel'. Indeed, as mentioned in the beginning, the recruitment of Chinese workers to Israel has consistently spread across China to include more provinces.

Second, many Chinese migrants never fully understand the Israeli legal and contractual framework that took them in. They often unknowingly violate the conditions of their work visa due to the manipulation of Israeli employers. When arrested by the police and deported, there is little they can advise future migrants, as they rarely grasped the systematic fashion in which the exploitative system worked. This ignorance led many deportees to focus their blame on a particular Israeli employer, a specific recruitment company, or simply their personal 'bad luck'.

The inability of many Chinese to understand the workings of the legal system was compounded by cultural differences. My interviews revealed that many Chinese workers are used to a system that is fundamentally based on hierarchy rather than official law. According to this system, the people who are positioned higher in the hierarchy always represent the law for their subordinates. Thus, when an Israeli employer 'sold' his workers, he could simply order them to work for someone else without having to face questions such as: For whom are we working? Is it legal? Is it according to our contracts?

The final and arguably most important factor that leads many Chinese people to desire employment in Israel despite the exploitative legal system was the paradoxical situation whereby migrant workers who lost their legal status often found themselves in a better economic position as undocumented migrants. An extensive survey revealed that 73 per cent of former migrant workers in Israel improved their salaries once they left their exclusive employers (and thus became undocumented); 45 per cent also reported an improvement in the treatment they received from their new employers (Ministry of Labour 2001: 50).

Undocumented workers are not bound to one employer and can thus offer their services in the 'black' Israeli labour market and earn competitive salaries. Employers of undocumented workers know that ill treatment would almost immediately lead these workers to search for better employers. Thus, in their working relations with undocumented workers, many employers exercised what we can call 'utilitarian opportunism', that is, employers treated their workers with fairness and even kindness, which ensured that workers continued their employment under conditions that were still very profitable for employers. Interestingly, the survey also discovered that 48 per cent of all undocumented workers had been employed in the construction sector, which was also the chief sector for the employment of legal migrant workers 
(ibid. 50). Thus, improvement in the conditions of undocumented workers often occurred within the same sector in which they had worked as legal migrant workers.

Over time, many Chinese learned that they could earn much more money by working as independent day workers. They thus often purposely left their exclusive employer for more profitable but illegal independent work. These Chinese workers began hanging out at specific road intersections that were known to Israeli employers and ordinary citizens who wished to contract undocumented workers. Some Chinese gradually acquired a workable command of the Hebrew language and a circle of trusted Israeli employers who regularly contacted them on their mobile phones, thus freeing them from the risk of standing at intersections that were sometimes raided by the Immigration Police.

Chinese workers who forcefully or purposely moved from a legal to an illegal status recall this transition with mixed feelings. In the words of a veteran Chinese:

In that period [of illegal employment], we were making more money than ever before. If you worked at intersections it was up and down, sometimes you had a lot of work and sometimes less, but we were our own boss; we could decide what job we take and where we work. Of course, sometimes you still had to deal with layers who didn't want to pay you for your work. And of course I was afraid [of being arrested by the Immigration Police], everyone was. It was always on your mind but in the period before the Immigration Police [was established], there were not many arrests. You had to be careful but it was ok. I remember thinking to myself that it would be perfect if I could go on working like this but with a legal visa.

Knowing that Israel invested little effort in deportation campaigns, many Chinese migrants arrived in Israel in the years $200 \mathrm{I}$ and 2002 with the clear intention of leaving their designated employers and working illegally. They were often encouraged to act in this way by their relatives and friends in Israel who had already been working successfully in this fashion and could assist newcomers with finding 'black' jobs.

Indeed, until the year 2002 (as illustrated in figure 2) only a tiny fraction of the total number of undocumented migrants in Israel was deported each year. While Israel has always vowed to expel all undocumented migrants, deportation campaigns were regularly undermined by failures to properly budget for the necessary extra police force, juridical personnel and detention facilities.

However, in September 2002, Israel inaugurated a special Immigration Police whose task was to locate, arrest and deport 50,000 
Figure 1.2 Deported undocumented migrants, 1995-2001

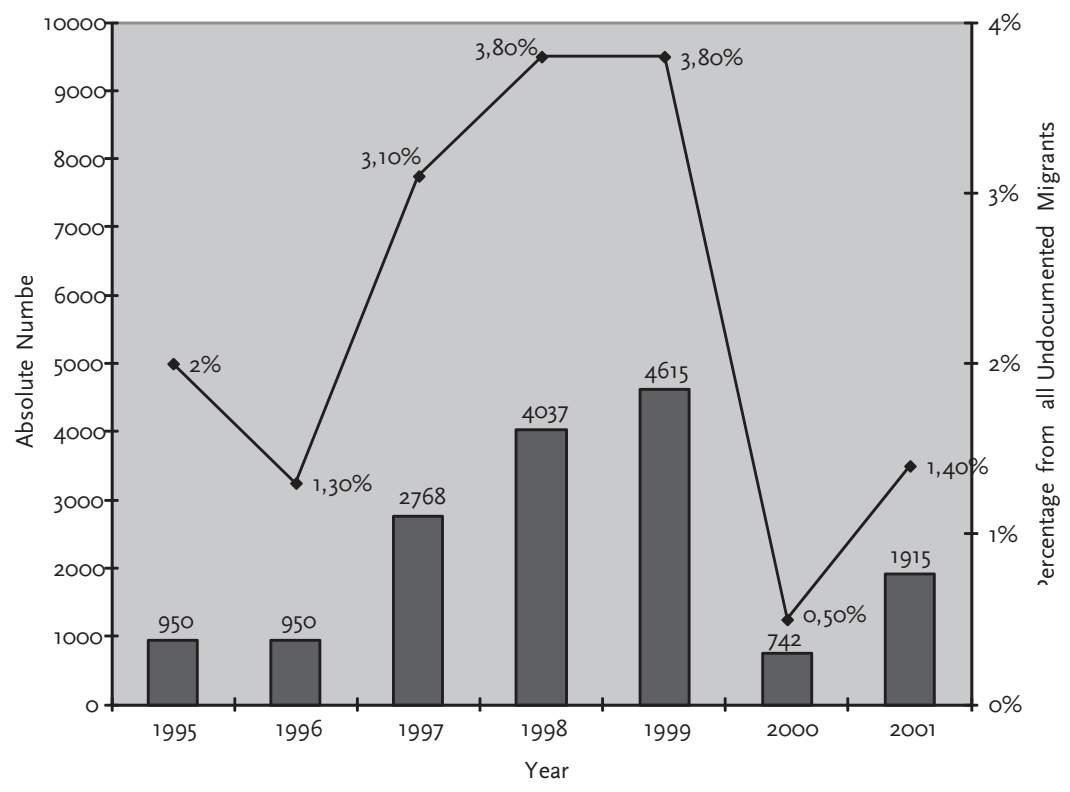

undocumented migrants in its first year of operation and many more in subsequent years. This time, a substantial budget was allocated for executing the task, and more than seventy officers and 400 policemen were recruited. In addition, special courts now operated within detention centres and ruled on cases of arrested undocumented workers. The Immigration Police managed to deport around 25,000 migrants, creating a ripple effect of intimidation that induced an estimated 55,000 more undocumented migrants to exit the country (Kalir 20I0; Willen 2007).

The shift in the Israeli approach towards undocumented migrants was the result of two main factors. First, while few undocumented migrants were deported, many increasingly settled down, establishing elaborate communities and networks. The evident settlement of nonJewish migrants rendered it unsustainable for the state to continue practicing a 'blind eye' policy. Second, from an economic perspective, around the year 2000, Israel needed less migrant workers. The strain in the construction sector eased after the housing crisis of Jewish immigrants had been largely solved. The more acute predicament facing the Israeli economy in the early twenty-first century was the persistently high unemployment rate among Israelis and a looming economic recession. The working assumption of Israeli policymakers was that by 
toughening the conditions for welfare benefits and deporting undocumented migrants, jobs would become available for long-term unemployed Israelis (see The Jewish Week Io October 2003; Haaretz I5 June 2005).

In its operations against undocumented migrants, Israel regularly ignored its own laws and resorted to illegal methods. In the following section, I highlight the actions that Israeli authorities have been taking in their treatment of migrant workers in general and in their fight against undocumented workers in particular.

\section{The Role of the State}

Different Israeli state and non-state actors repeatedly alerted the Israeli government about the structural and legal failings of the importation process, which led to the widespread exploitation of migrant workers. These actors included Israeli academics (Drori \& Kunda I999; Schnell I999; Kemp et al. 2000), NGOs, the State Comptroller (I996, I999) and the Bank of Israel, which asserted already in 2000 that 'the current system of granting work permits must be altered' (Press Release December 2000). Despite these repeated calls, the government did little to change the 'binding arrangement'. Israel's insistence on keeping the importation scheme intact reflects its general concern with providing the national economy with cheap labour as well as its particular bias towards the interests of Israeli employers in the construction and agricultural sectors. Israeli employers in these sectors have historically been well organised and exercise significant political power on any ruling government through powerful lobbies. It was indeed due to pressure from these lobbies that the exploitative 'binding arrangement' was applied by Israel in the first place (Bartram I998).

Besides doing little to amend the 'binding arrangement', the Israeli authorities assisted employers in both direct and indirect ways to exploit migrant workers. The following are a few illustrations of this type of assistance. Israel rarely enforced the living and working conditions that employers were obliged to provide migrant workers. As the State Comptroller (I996: 494) gloomily asserted: 'In practice, employers that accommodated foreign workers in improper conditions are not being penalised. There is a record of only three cases in which the work permits of guilty employers were cancelled'. The government also made little effort to enforce the Minimum Wage Law (1987) in the case of migrant workers. The Bank of Israel found that between 1996 and 2000 , an average of 56 per cent of migrant workers were unlawfully paid below minimum wage. Other labour laws like The Hours of Work and Rest Law (I95I) and The Severance Pay Law (I953) were also widely 
violated by employers, with no serious action taken by the authorities (Schnell 200I). The Ministry of Labour designated only thirteen supervisors for the enforcement of labour laws in sectors where migrant workers were employed, and these supervisors mainly focused their efforts on the detection of undocumented workers, while the actual enforcement of migrant workers' rights was seriously neglected (Yanay \& Borowosky i998).

Israeli employers often confiscated the passports of their workers in order to exercise even greater control over them. Confiscating passports constitutes a criminal offence in Israel that carries a penalty of up to one year in prison (Penal Law, article 376-a). Israeli NGOs assisted hundreds of migrant workers to complain about the confiscation of their passports; nevertheless, the police took little if any action to follow up on these complaints and to bring the violating employers to court. Israeli authorities actually collaborated with employers in this unlawful practice. Officials from the Interior Ministry who were responsible for checking migrant workers' passports upon arrival commonly returned the passports not to the workers but to their Israeli employers, who then kept them (The Association for Civil Rights in Israel I997: 55).

This more active manner in which state officials assisted employers instead of protecting exploited migrant workers became more evident in the case of undocumented workers. For example, Israeli employers often called the police to arrest their migrant workers who had been dismissed and thus lost their legal status. Employers sometimes used this method to get rid of workers to whom they owed several months' salaries. The police regularly arrested and deported workers before the dispute over their salaries could be resolved in court.

When the Immigration Police began its operation in 2002, it almost exclusively focused its efforts on the detention of undocumented migrants rather than equally targeting Israeli employers who contracted these migrants. Since employing undocumented migrants is illegal in Israel, tackling the phenomenon is arguably more effective when equally enforcing the law on Israeli employers. Yet even on occasions when the police inspected, found and arrested undocumented migrants in construction sites or factories, the Israeli employers were regularly spared from legal charges.

Techniques used by the Immigration Police for apprehending undocumented migrants included knocking down doors with heavy hammers and breaking into suspected undocumented migrants' apartments in the middle of the night, often without warning. Suspects were handcuffed and loaded on to vans or buses as if they were dangerous criminals. While the Immigration Police claims to always act strictly according to the law, the many cases that were reported by NGOs and the media, and at times brought to court, present a different picture - one 
of brutal apprehensions with little consideration for the traumatic affects that an arrest could have for the individuals involved. Reports by NGOs detail the recurrent mismanagement of authority by the Immigration Police and the general trampling on migrants' rights throughout the deportation process (see Hotline for Migrant Workers and Kav La'Oved 2003, 2004; The Jerusalem Report 2I May 2003; Dahan \& Gill 2006).

Once arrested, the legal procedures for treating suspected undocumented migrants were not always kept. From one report that surveyed the legal treatment of III detainees, it appears that in 46 per cent of the hearings that were held, there was no presence of a translator, and detainees could not understand what was said nor could they present their version to the court. Consequently, a number of detainees were sentenced for deportation because they allegedly refused to cooperate with the court. Some of these cases were reversed once a translator was found and it became clear that the detainees were very willing to provide their side of the story (Hotline for Migrant Workers 2003b).

The Israeli law stipulates that detainees must be brought to court within two weeks from the day of their arrest, or else they should be unconditionally released. The above-mentioned report documents many cases in which detainees were held in custody for longer than I4 days without seeing a judge. Appeals by NGOs to authorities in the detention centres as well as to officials at the Interior Ministry were never answered. Finally, the report also mentions numerous cases in which suspected undocumented migrants were deported before they were ever brought before a court.

\section{The Accountability Field for State's Actions vis-à-vis Migrant Workers}

The illegal manner in which Israel has conducted many of its operations against migrant workers raises the following question: how can the state of Israel get away with its illegal conduct vis-à-vis migrant workers? To attempt to answer this question, we must first delineate the accountability field in which the state operates. There are four potential fronts on which Israel might stand accountable for its conduct vis-à-vis migrant workers. In what follows, I address the influence of each front on the conduct of the Israeli authorities.

\section{Migrants' Sending State}

China could undoubtedly exercise some political and economic leverage on Israel to try to have its exploitative policies and illegal actions vis-à- 
vis Chinese migrant workers changed. It is nevertheless clear that China has chosen not to interfere with Israel's handling of its immigration process. I mentioned earlier the blind-eye policy that the central government in China adopts when it comes to the informal migration industry. I found much support for this official Chinese line in my interview with the Chinese consul in Israel. Here is the consul's general view on the system: 'In China, we call it a win-win-win situation. All sides win out: China is able to export workers, Israel is happy to receive cheap workers who are willing to do the jobs Israelis don't want to do, and the migrants can earn and save a lot of money for their families'.

When I politely asked the consul if he was aware of the widespread exploitation of Chinese workers by Israeli employers, the consul opined that 'Everything goes well if they [Chinese workers] don't do illegal things'. When I asserted that according to most independent sources, including NGOs and journalists but also some Israeli state institutions, the blame for the systematic exploitation of migrant workers lies with Israeli employers, unfair Israeli regulations and a lack of enforcement of workers' rights by Israeli authorities, the consul laconically reacted: 'If the problem is with the Israeli employer, we try to call him and solve it'.

When I asked about the informal fees that workers pay recruitment companies in China, the consul first dismissed my claim as sheer rumours, but when I insisted that my knowledge in this matter comes from interviews I personally conducted with Chinese in Israel, the consul had this to say:

Listen, in China we have now a free market economy. You probably know that lately we even joined the WTO. It is the market which decides if people will go abroad, not the government. So they pay these fees to agencies, but they still earn a lot of money, otherwise they wouldn't have come here, right? People know how much they have to pay and they can decide if it is good for them to emigrate. Usually, what they pay to agencies is equivalent to two years of work in Israel. But they stay here longer, often even five years, the rest of the time they work and earn money for their families. If they had to work four years to pay agencies they would probably not come here. Did they also tell you how much they save? You know what? It is not a win-winwin situation; it is a win-win-win-win situation. [Laughing out loud at his gag]. The agencies also win, but it is still a good deal for all sides.

This statement demonstrates that the consul is not only fully aware of the informal payment of fees but that he sees it as an unproblematic issue. 


\section{International Law, Treaties and Conventions}

Israel is a signatory to UN conventions that define and safeguard the working and living conditions of migrant workers, including those of undocumented migrants. Nevertheless, Israel has regularly ignored UN resolutions and violated international conventions whenever they seemed to interfere with what Israel perceived to be its national responsibility. Israel's immigration regime is closely tied to its aspiration to maintain a Jewish state in Israel, and it is therefore considered an internal affair not to be interfered with by other states or international organisations. Nonetheless, some of the changes that resulted from legal appeals to Israeli courts (see section below) were facilitated by an increased Israeli accountability to an emerging global regime of human rights anchored in international conventions to which Israel is a signatory. In these appeals, Israeli courts regularly recognised the responsibility of the government towards migrants as defined in international treaties.

\section{Israeli Courts}

The most effective way to influence changes in the Israeli policy vis-àvis migrant workers has proven to be legal appeals to Israeli courts. Such appeals were mostly filed by lawyers working for Israeli NGOs. The changes that Israeli NGOs managed to achieve through the courts include: temporary halts in deportation campaigns, a reduced period of time in which detainees must be brought before a court, regulated healthcare for migrant workers, the possibility for dismissed migrant workers to find new Israeli employers and thus keep their legal status and avoid deportation, an imperative to abolish the 'binding arrangement' and introduce a new employment scheme for migrant workers, and the permanent legalisation of status for undocumented migrants with children who were born and raised in Israel.

However, even when Israeli courts have given clear verdicts that obliged the state to amend related regulations and enforce the rights of migrant workers, the state often did its utmost to delay the implementation of changes by appealing such rulings to higher legal instances or by asking the court for a lengthy period of time in which to plan and prepare for the necessary amendments. In some cases, as mentioned in the previous section, the state simply disregarded the court's ruling and continued its unlawful treatment of migrant workers.

\section{Civil Society and Public Opinion}

Israeli NGOs have undoubtedly played a major role in challenging the exploitative Israeli 'binding arrangement' and in fighting more 
generally for the rights of migrant workers. Yet much of the leverage that NGOs exercise in trying to influence migration policy and the treatment of migrants by different state authorities depends on a wider public support that they are able to mobilise for their efforts. Israeli public opinion towards migrant workers can thus be seen as a larger context for the legitimisation of the state's policy and actions. While the state has acted in an illegal and often inhumane manner towards migrant workers, there has hardly ever been a public outcry over the legitimacy of such illegal actions. This leads us to the following question: why was the illegal conduct of various Israeli state authorities against migrant workers perceived by a majority of the Israeli public to be licit? ${ }^{\mathrm{I} 3}$

Before answering this question, I would like first to analytically situate it within the 'illegal but licit' framework as advanced by Van Schendel and Abraham (2005).

\section{Expanding the 'Illegal But Licit' Framework}

The 'illegal but licit' framework, while not avoiding the nation-state as a significant point of reference, attempts to relativise the absolute supremacy of the state in the analysis. It does so by calling our attention to the viewpoint of people who are involved in transnational flows. This viewpoint from 'below' can at times be out of sync with the formal view from 'above' - i.e. that which is represented by state laws.

To schematically explain their analytical framework, Van Schendel and Abraham (2005: 20) offer the following matrix of 'spaces of competing authorities', which I reproduce here in table I.I.

Table 1.1 Table of spaces of competing authorities

\begin{tabular}{lll}
\hline & Legal & Illegal \\
\hline Licit & {$[$ A] Ideal State } & {$[B]$ Underworld/Borderland } \\
Illicit & {$[$ C] Crony Capitalism/Failed State } & {$[D]$ Anarchy } \\
\hline
\end{tabular}

The competing authorities here are the formal political authority of states (legal-illegal) and the non-formal social authority of members in societies (licit-illicit). While states hold the capacity to define that which is il/legal under their jurisdiction, members in society can nonetheless perceive things/actions/flows to be licit, given their subjective viewpoint and position as actors.

While a complete overlap between the state's legal definitions and people's perceptions produces a utopian 'ideal state', a negative overlap produces a state of 'anarchy'. Yet the interesting insight and use-value of this 
matrix clearly lie in the mismatches it highlights. Cell [C] captures situations in which the laws of the state permit illicit corporative conduct, like money laundering in the Cayman Islands or an 'Enron stage of capitalism' in the US which allows close (and often corruptive and corrupting) ties between politicians and private businesses. In its extreme, cell [C] represents a state's inability to define and protect the 'legal' against the 'illicit', leading to a collapse of the state as a valid political unit of organisation. Cell [B] calls attention to situations in which people routinely and knowingly act not in accordance with the official law but in a way that they take to be - within their social and spatial context - justifiable and rightful. The two prime examples here are the underworld (as in markets for counterfeited goods) and the borderland (as in the illegal cross-border practices that constitute an integral part of the daily life and livelihood of people who reside in the vicinity of international borders).

Notwithstanding the usefulness of this matrix, it is important to carefully examine its contours. The matrix mostly treats the state in its capacity as the legislator, defining il/legality. The state's definitions of il/ legality then qualify the actions of people and either correspond to or deviate from their own perceptions of il/licitness. The matrix thus limits our conceptualisation of the state to its role as the producer of il/ legality, while it reserves for people in society the role of actors.

Obviously, Van Schendel and Abraham (2005) endow the state with agency in that it responds to people's perceptions and actions, and factors these inputs into a continuous process of renegotiation and amendment of laws. Yet defining il/legality is distinguishable - both theoretically and in practice - from the executive authority of states. Executive authority is manifested in and practiced through the actions of the personnel in various state institutions - i.e. policemen, ministers, judges, civil servants, etc. The state is, of course, not a monolithic entity, and it is not uncommon to find contradictions and ambiguities in and between the actions of different state institutions and functionaries.

We thus should examine the state as an actor in the realm of what it has defined to be il/legal. This exercise amounts to a reversal in the directionality of the relationship between the two protagonists in the 'illegal but licit' matrix. Consider the following matrix whereby the state (on top) is treated in its executive capacity while the public/society (on the left) is the qualifier of state actions (see table I.2).

Table 1.2 Table of legitimacy of state executive power

\begin{tabular}{lll}
\hline & Legal & Illegal \\
\hline Licit & {$[\mathrm{A}]$ Legitimate Rule } & {$[B]$ Undisputed Legitimacy } \\
Illicit & {$[\mathrm{C}]$ Crisis of Legitimacy/Authoritarian Regime } & {$[D]$ Occupation } \\
\hline
\end{tabular}


Just like in the first matrix, cells [A] and [D] are straightforward, and the interesting insight results from the odd intersections the matrix foregrounds. Cell $[\mathrm{A}]$ represents a complete overlap between the actions of the state and the view of the public regarding these actions, thereby producing an ideal legitimate rule. Cell [D] represents an illegal occupation of the state which is met with a total disapproval by the occupied society. This kind of illegitimate occupation of the state can be external when it is performed by hostile state(s) - or internal, such as when a coup d'état is led by a minority group that lacks support in society at large. Due to its inherent illegitimacy, occupation must rest on constant intimidation and the use of violence.

Cell [C] stands for a situation whereby the state acts in a legal fashion but the populace perceives it to be illicit. We are then faced with a crisis of legitimacy, which can be resolved in different ways. In a democratic regime, such a crisis can lead to new elections which can renew legitimacy in the elected government. When the crisis cuts deeper, encompassing the very type of regime, we face a potential regime change of the kind we recently saw in Georgia - from a one-party Soviet system to a multi-party democracy - or in Venezuela and Bolivia, where a Western-style democracy was replaced by a socialist system. If the crisis in legitimacy of a governing elite is not resolved, we can usually expect the regime to gradually become authoritarian, relying on coercion rather than consent.

Most relevant for my discussion in this paper is the case captured in cell [B]. This cell highlights the possibility for illegal state actions to be perceived as licit by the majority in society. In this peculiar situation of 'undisputed legitimacy', as I call it, the state can expand its actions beyond the restrictions of its own laws without suffering a major loss in its legitimacy. The most prominent example of this is when a state launches a military offensive against another state in an apparent violation of international law and/or its own constitution but nevertheless receives popular support internally for its actions. The United States' pre-emptive wars in Afghanistan and Iraq are a case in point. The passing of the Patriot Act is another, more sophisticated example whereby the state seeks to expand the existing law to encompass illegal actions it is already taking, and which have broad public support.

Indeed, situations that fit into cell [B] usually occur in times of national emergencies. In fact, the possibility for governments to declare martial law in acute situations is an institutionalised recognition of the need for the state elite to enjoy undisputed legitimacy in times of severe danger to the existence of the state. Given that cases captured in cell [B] mostly represent a state of emergency, it is rather peculiar that many of the actions that states take towards migrant workers also belong in the same category. 
Tellingly, states across the world tend to portray (perceived) oversized flows of immigrants - and especially undocumented migrants - as constituting a national threat. It is construed as a threat to the sustainability of the state's infrastructure (hospitals, schools) and resources (welfare), its national security as well as the integrity of its nation and 'culture' (whatever the latter stands for in the eyes of politicians). To combat undesired immigration, states often call for the deployment of means that are associated with an emergency situation: the building of physical barriers, the passing of draconian exclusionary regulations and the deployment of the army or special police force.

\section{Conclusion: Migrant Workers as Non-Subjects in Modern Polities}

I would now like to return to the empirical case of Israel and clarify the undisputed legitimacy that Israeli authorities have enjoyed when treating migrant workers in illegal and inhumane ways. The state of Israel has been internationally recognised (UN Resolution 1947) and legally established (The Declaration of Independence 1948) as a Jewish state that fulfills the historical aspiration of the Jewish nation to establish a sovereign state. Israel's declared purpose has been to serve as a 'home' for Jews worldwide. Inspired by the Zionist ideal of the 'foregathering of the diaspora', the criteria for the inclusion of immigrants as Israeli citizens were ethno-religiously defined to conform exclusively to people of Jewish origin.

Surprisingly, perhaps, public opinion in Israel was initially considerably supportive of, and tolerant towards, non-Jewish migrant workers (Bar-Tzuri 1996). While some Jewish Israelis clearly held prejudiced views about 'foreign workers', tellingly, those who came into contact with them held more positive views. Accordingly, the residents of Tel Aviv, where most undocumented migrants resided, displayed the most tolerant attitude towards non-Jewish workers (Nathanson \& Bar-Tzuri I999: I04, II5). This positive attitude was based not least on the cheap labour that migrant workers provided many Israeli businesses and ordinary citizens.

However, Israeli public opinion has proven to be highly responsive to the state's nationalistic rhetoric. Since the government launched its first deportation campaign in 1996 , it regularly alleged that non-Jewish migrants were corrupting the Jewish character of the state as well as increasing criminality and unemployment among Israelis (Willen 2007). As a result, support for migrant workers has steadily deteriorated among the general Israeli public (Nathanson \& Bar-Tzuri 1999) as well as among the residents of Tel Aviv (Schnell I999). 
It is fair to assume that some Israelis were influenced purely by the state's rhetoric and were not directly affected in a negative sense by the presence of non-Jewish migrant workers. Yet some Israelis, especially unskilled workers, might have suffered from competition with an increasing number of migrant workers. It has been demonstrated that the disadvantaged groups in Israel (those with low income and/or low education, the unemployed, and Palestinian citizens of Israel) were most likely to endorse economic discrimination against migrant workers (Semyonov et al. 2002). Disadvantaged Israelis clearly perceived migrant workers as a threat to their economic interests. However, it was further shown that Jewish Israelis expressed significantly more hostility towards migrant workers than did Palestinian citizens of Israel, although the latter were more prone to suffer from competition with migrant workers. It was thus concluded that the attitudes of Jews are also motivated by 'sentiments which are entirely exogenous to labour market competition ... [and are largely explained by] the ideological commitment (among Jews) to preserve the Jewish character of the State ... non-national workers are evaluated not only as economic competitors, but also as a threat to the very essence of the social and political order of the state and to its national (Jewish) identity' (Semyonov et al. 2002: 428). As we can see, public opinion in Israel is closely influenced by a firm endorsement of the need to maintain Israel's Jewish character and the idea that migrant workers pose a threat to this ideal.

Pierre Bourdieu (I996) argued that Weber's classic definition of the state as holding the monopoly over the legitimate use of violence should be supplemented by its dominance over symbolic power. With this, Bourdieu wishes to draw our attention to the power of the state in shaping the social categories through which members in the polity perceive their own experiences as well as the actions of the state. In other words, the state, according to Bourdieu, "is not only "out there" in the form of bureaucracies, authorities, and ceremonies. It is also "in here," ineffaceably engraved within us, lodged in the intimacy of our being in the shared manners in which we feel, think, and judge. Not the army, the asylum, the hospital, and the jail, but the school is the state's most potent conduit and servant' (Wacquant I996: xviii).

Israel has historically insisted on an overt representation of its Jewish character on a symbolic level (e.g. a flag with the Star of David, a national hymn that praises the return of Jews to Israel). Recognising the overall dominance of the Jewish citizenry, some academics have charged that Israel constitutes an 'ethnic republic' (Rabinowitz I997; Ghanem I998) or even an 'ethnocracy' (Yiftachel I997). These critics point to the legal framework that Israel put in place to safeguard the Jewish character of the state. Moreover, national belonging in Israel is overwhelming determined by one's ethno-religious identity - in other 
words, one's Jewishness. The validity of this ethno-religious criterion is naturalised by the state and internalised by most Israeli citizens via a particular understanding and teaching of the history of the Jewish nation, the Israeli education system, the army, the celebration of national festivities and Remembrance Days, and so forth.

This symbolic power, which is invested in shaping the perceptions of Israeli citizens, leads a majority to recognise non-Jewish migrants as invalid subjects in the Jewish state. Even when Jewish Israelis show sympathy towards migrants, they often conceive the bigger picture in a way that is neatly captured in the following quote from one of my Israeli informants:

I have nothing against them [non-Jewish migrants], many of them are very honest people who come here because they want to take care of their poor families in their countries. But when they come here they know they come to a Jewish state where they can never stay. They know and take the risk involved. So when Israel decides that they have to leave and deport them, what do they expect? They have to go back to their countries. I'm sorry but it's Israel's right. There are hundreds of states in the world and only one is a Jewish state.

According to widespread perceptions in Israel, non-Jewish migrant workers do not belong in Israel, and they are consequently never fully registered as 'real' subjects in the mindscape of Jewish Israelis. This dynamic is amplified in the case of undocumented migrants, who are often seen as transgressors that disregard the law and disrespect the national sovereignty of the state. In the eyes of many citizens, the illegal actions and status of undocumented migrants justify the hard-line approach of the state, including the 'right' to use illegal methods against them (De Genova 2002).

We can therefore conclude that the illegal but licit actions of the state against migrant workers are by and large the result of hermetic mental borders that are produced by the state with the use of symbolic power and imprinted onto citizens' mindsets. Migrants that cross the territorial borders of the state are often unable to cross the more impenetrable mental borders that are firmly held by many of the recognised members of the nation (see also Wong and Pok Suan in this volume). In this sense, the position of many migrant workers - both legal and illegal, as the case of the Chinese workers in Israel demonstrates - can be equated with the figure of the homo sacer, as advanced by the Italian philosopher Giorgio Agamben (1998). The homo sacer is a depoliticised human who is not a member of the political community and over whom the sovereignty of the state does not apply. Homo sacer can therefore be killed 
with impunity, but not sacrificed. It is the non-belongingness and exteriority of homo sacer that allows recognised members in the polity to reassure themselves (or hold to the illusion, as Agmben would have it) about the link between membership in a political community, a regime of rights, and territorial sovereignty.

The greater the overlap in the attitude towards migrants between the state's formal approach and people's social perceptions, the greater the chance that the state will enjoy undisputed legitimacy as it acts against migrants, even in an illegal and inhumane manner. Yet a total overlap hardly ever exists, not even in the extreme case of the Israeli state. Many Israeli civil society actors clearly managed to escape the symbolic power of the state and persistently fought to change Israel's exclusionary, exploitative and often illegal treatment of migrant workers. These actors used Israel's democratic characteristics, which included freedom of association, freedom of speech and the government's accountability to Israeli laws and international conventions. Astutely, civil society actors compared the Jewish history of ethnic persecution with the situation of many non-Jewish migrant workers in Israel. This dreadful contrast effectively touched upon the very sensitivity that had historically led most Israeli politicians to vigorously establish and closely protect the Jewish state. Consequently, it led many liberal as well as right-wing conservative politicians to amend existing regulations and to even support the legal incorporation of certain non-Jewish migrants as citizens of Israel.

\section{Notes}

I This work is part of the 'Illegal but Licit' research programme, which is financed by the Netherlands Organisation for Scientific Research (NWO). For my research project within this programme, I conducted a non-consecutive ethnographic fieldwork over a period of nine months among Chinese workers in Israel in the years 2006 to 2010 . During these years, I also made four field trips to China, each for a period of around two weeks, for visiting potential migrants to Israel as well as deportees and returned migrants from Israel.

2 http://www.chinaembassy.org.il/eng/ (accessed on I2 May 2007)

3 A small number of around Ioo Chinese 'chefs' are recruited for work in kitchens of Israeli-owned Asian restaurants. In this article, I do not refer to this group of Chinese, who are significantly different in their characteristics and employment conditions in Israel.

4 There are, however, several cases in recent years of mixed marriages between Israeli men and Chinese women.

5 For how this non-assimilative inclination led some Chinese to seek a conversion to Christianity - and not Judaism - while in Israel, see Kalir 2009 .

6 When speaking of an informal migration industry, one should not immediately envisage underground operations carried by the Mafia. As Thunø and Pieke (2005: 487) inform: 'no convincing evidence, however, exists that well-organised Chinese triads or 
gangs are the primary masterminds and main operators behind smuggling or trafficking of Chinese migrants' (see also Chin 1999; Pieke, Nyiri, Thuno \& Ceccagno 2004).

7 I disregard here a small number of Chinese who enter Israel as tourists and remain to work illegally, and an even smaller number who get smuggled into Israel from the border with Egypt.

8 See Internal Report for the Israeli Parliament 2002.

9 In 2006 , the law was amended to allow recruitment companies to charge workers a fee of up to US\$700.

Io The eagerness of the Chinese to go to Israel must be seen in the wider context whereby much higher prices (sometimes of around US\$ I00,000) are paid by Chinese in order to get to other, more attractive migration destinations like the US and the UK.

II Interview by author, Israeli Consulate in Beijing, China, December 2007.

I2 Some employers asked their workers to pay them as much as US\$ 500 for the renewal of visas each year.

I3 It might even be that the public does not overtly legitimise the state actions vis-à-vis undocumented migrants, but by not voicing contempt, expressing rejection or mobilising resistance, it nonetheless connives with these actions. 


\title{
2 Contesting the State of Exception in the Afghan- Pakistani Marchlands
}

\author{
Oskar Verkaaik, Sarfraz Khan and Samina Rehman
}

The so-called tribal areas in northwest Pakistan are in the international limelight due to its continuing significance for the political situation in both Afghanistan and Pakistan. Ever since the Soviet invasion of Afghanistan in 1978, these borderlands have been intrinsically connected to the war in Afghanistan. Millions of refugees have found a place to stay here during the last three decades. The Afghan resistance known as the mujahideen largely operated from these areas - both $\mathrm{Al}$ Qaeda and the Taliban as well as lesser-known jihadi groups were formed and trained from here, and it is widely believed that Al Qaeda leaders including Osama bin Laden himself had/have been hiding in this mountainous region. Today, the tribal areas are the arena in which the Pakistani army and militant organisations such as the Pakistani Taliban clash. The tribal areas have witnessed all this primarily because of its unique legal status as a part of Pakistan where the state has given up its formal authority to so-called tribal customary law. In effect, the region is ruled by what we will call the state of exception. ${ }^{\text {I }}$

Our concern in this chapter is not primarily with the tribal areas as an arena of international politics. We are instead interested in the effect of the unique legal arrangement on the local population, and especially the ways in which the state of exception is contested. Clearly this is related to the international politics that is being played out within the tribal areas, but it cannot be reduced to that alone. A growing number of people in the tribal areas are no longer satisfied with their special status. Because the state of exception is based on the notion of tribal culture, it is precisely this ideological foundation that has come under attack from various sides. There are at present three discursive alternatives available: I) Islam, 2) a redefinition of tribal culture in terms of Pakhtun nationalism and 3) references to modernity and the notion of universal civilisation. We will argue that these discourses are not just regimes of licitness in the sense that they depict existing power structures and cultural institutions as morally wrong or corrupt, but that they also endorse alternative legal systems - respectively, the shariat, a redefinition of customary law, and universal human rights or the Pakistani 
constitution. Each of these formations of licitness and legality legitimise certain power positions and contest others.

In this paper, we furthermore want to point out that the discursive traditions we will describe transect the analytical distinction between licitness and legality. Each of them is a moral language, derived from religious, cultural and civilisational traditions, but all of them also put forward a distinct legal system. The conservative notion of tribal culture validates customary law; Islamism promotes the shariat; progressive Pakhtun nationalism would like to see a combination of the state's rule of law with what is seen as grassroots democratic forms like the people's jirga; modernism endorses human rights. What is perhaps unique in the case of the tribal areas is the extent to which contesting discourses of licitness express themselves also in a legal language. This suggests that the state's right to formulate, exercise and defend its rule of law is fundamentally challenged. The reason for this, we think, is twofold. It first links up with a wider legitimacy crisis of the Pakistani state that can also be found outside the tribal areas. Pakistan's past, in which democratically elected governments were time and again dismissed on military orders, has seriously harmed the authority of both the democratic state and the army (Verkaaik 2004). What is unique about the tribal areas, however, is that the state has never claimed full sovereignty. There has, in other words, never been an undisputed system of legality that allows for zones of activities that can be tolerated as licit. In the absence of a hegemonic legal system, discussions about what is and what is not licit are not framed as criticisms within the parameters of the legal system but become debates in search of a legal system that authorises a moral position. The tribal areas do not suffer from a crisis of authority but from a proliferation of authorising discourses.

\section{The State of Exception}

In a recent book, Talal Asad points out the fundamental tension on which the authority of the modern nation-state rests. The bureaucratic rule of law is at once a system of legal arrangements and the ideological foundation of this system (Asad 2007). As Claude Lefort (I988), among others, has argued before, the bureaucratic rule of law does not recognise an external source of legitimation that justifies its existence. It legitimises itself; in that sense, it is 'post-foundational' (Euben I999). As a consequence, the power of the modern bureaucratic state is only limited by the rule of law itself. The notion of the trias politica, one could argue, has been invented to deal with that very tension. Of course, it was meant to curb the unlimited power of heads of state that was seen 
as an extension of the divine, but abolishing that divine legitimation does not in itself solve the problem of despotism, as the history of the twentieth century has made clear. Despotism is now justified in the state's own name instead of that of the divine. Some, notably Max Weber, conceptualised this tension by arguing that the rule of law is itself imbued with charisma, a point that has been taken further by authors like Philip Abrams (1988), Timothy Mitchell (1988, I999), George Steinmetz (I999) and Thomas Blom Hansen together with Finn Stepputat (200I). For others, the rule of law conceals the state of exception that forms the violent backbone of the modern state and which can be revealed when the rule of law is attacked, for instance by 'terrorist attacks' (Agamben I998; Hansen \& Stepputat 2005). For the radical left - from the Russian anarchists to the German RAF - this state of exception shows the 'real' face of the state. Whereas this argument surely is a violent essentialism of its own kind, recent responses to 'terrorism' indicate the extent to which states - be it the US, Russia, Israel or Pakistan - operate outside their own rule of law, thereby at once damaging their own source of ideological legitimation and enhancing their authority. Without defining the state of exception as the modern state's core, then, we cannot ignore this ideological vacuum if we want to understand the regimes of legality and licitness that surround, or contest, the modern state.

In other words, although the modern state defines itself in terms of legality and the rule of law, it actively creates moments and spaces where it can licitly operate outside the rule of law. As Diana Wong and Tan Pok Suan formulate it in this volume, while creating legibility, modern states also generate 'vast domains of invisibility' - that is, a range of arenas and activities that cannot be 'seen' and accounted for from a position of formal political authority. The modern state is not absent from these domains of invisibility but operates in them as an active agent. As Barak Kalir argues in his contribution to this volume, the "licit' is therefore not only a moral discourse of social groups challenging or bypassing the formal legal system on the basis of notions of licitness. The state itself can equally act in an illegal manner that is nonetheless considered 'licit' by state officials or others.

The so-called tribal areas in northwest Pakistan form an interesting case in point because they can be seen as the geographic incarnation of the state of exception. Since colonial times, the borderlands between Afghanistan and South Asia have been defined as areas ruled by tribal customary law, an arrangement the Pakistani state has adopted and endorsed since independence. The status of tribal territory as 'marchlands', first introduced by Lord Curzon in I899, has been around since then. The notion of tribal culture, in other words, has created a border region where the state has largely delegated its formal authority to tribal 
customary law and is therefore not bound to its own rule of law in its dealings with the local population or external forces. The notion of tribal culture gives the state a free hand in the Afghan-Pakistani borderlands. As a result, the tribal areas have become something like a permanent war zone, especially since the start of the Afghan wars in I978, where the Pakistani state operates in a Hobbesian world in which a large number of forces and militias operate, most of them foreign-sponsored. This is the area where the mujahideen, Al Qaeda, the Taliban both Afghan and Pakistani - and all sorts of militant organisations active in Kashmir have found their base. Not only the Pakistani state but also its sponsors, notably the US, have used the region as a training ground for several of these organisations and as a battlefield to fight them. The benefits of this arrangement are considerable: by containing these war activities within the tribal areas, for instance, the Pakistani state has so far managed to prevent the outbreak of a civil war in its major cities; foreign military and aid organisations have used the porosity of the borderlands to enter Afghanistan illegally; militias and the local population have benefited from large-scale smuggling activities. But the disadvantages are obvious, too: the region has remained extremely poor; basic services like clean water or education are scarce; women have no defence - legal or otherwise - against physical abuse; people in general lack the protection of the state and are instead victim of the state's partaking in corruption and violence; dominant readings of tribal customs and Islamic morality become more and more conservative; and so on (Hyder 2008). It is clear that the state of exception, starting in the colonial period and continuing today, has radically changed the region. To talk of traditional tribal culture or free tribes (azad qabail), as the population is officially known, is clearly a misnomer.

\section{The Tribal Areas}

The so-called tribal areas are officially known as the Federally Administered Tribal Areas (FATA) and are divided into seven agencies, all of which are located in the mountainous borderlands between the Indus Valley plains and Afghanistan. These seven agencies are Kurram, Khyber, North Waziristan, South Waziristan, Bajaur, Mohmand and Orakzai. Except for the latter, all of them border Afghanistan. Apart from these seven agencies, there are six so-called frontier regions that also share the same special status: Peshawar Frontier Region, Kohat, Bannu, Lakki, Dera Ismael Khan and Tank. In I998, the total population of the tribal areas was more than three million. Almost all of them belong to the Pakhtun qaum (an ethnic group), which includes various tribes (khel) such as the Afridi. 
According to the constitution, the FATA is officially ruled directly by the president of Pakistan, who, however, has delegated his authority to the governor of the North-West Frontier Province. Although the FATA is represented in the national assembly and the senate, neither the federal government nor the provincial assembly of the North-West Frontier Province can legislate for the tribal areas. Members of parliament from the tribal areas can legislate for the whole country but not for their own districts (Sial \& Yousufzai 2008). Real power lies in the hands of the so-called political agent of each tribal agency, who is assisted by a number of assistant political agents, and who is responsible for such matters as law and order, administration of development projects and the supervision of the tribal law system. The latter takes place according to the Frontier Crime Regulation (FCR), which was installed by the British colonial government in I90I. This regulation authorises the political agent to refer criminal cases - especially those considered to be cases of blood feud or honour-related issues - to a gathering of local leaders known as jirga. In principle, anyone living in the tribal areas can call for a jirga and present his or her case to this body of tribal elders. The jirga determines guilt or innocence and reports to the political agent, who then passes the sentence, which cannot be challenged. The Frontier Crime Regulation is furthermore based on collective rather than individual responsibility, meaning that the whole clan (khel) is considered responsible if a crime is committed in its area. If a person is convicted, it is considered the responsibility of the clan to hand him over. Failure to do so may be punished by collective fines or the confiscation or demolition of property. Neither the High Court nor the Supreme Court exercises any jurisdiction within the tribal areas.

This special status is a colonial construction (Bangash I996). When the British colonial army sought control over the main passes connecting South Asia with Afghanistan - mainly Khyber, Kurram and Bolan they found it difficult to establish and maintain power in these areas. The British seized control over government property and the main roads but made it clear that they had no intention of interfering in the internal affairs of the local population. Instead they formed the tribal agencies as we know today, installed a political agent in each agency and gave him full power and responsibility over the area, established the jirga system of today (known as sarkari jirga or government's jirga), and formed the international border between British colonial India and Afghanistan, known as the Durand Line, that still constitutes the border between Afghanistan and Pakistan. After I899, regular troops were withdrawn and replaced by special militias responsible for keeping law and order by punishing clans collectively when government property was attacked. The indirect rule system was also known as the maliki system because it relied on so-called traditional leaders (malik) who worked 
as middlemen for the government in return for which they received allowances and privileges. The title became a hereditary institution, imbued with the aura of tradition. Most members of the sarkari jirga are, and have been, malik. In colonial times, then, authority was officially in the hands of the political agent, who ruled by way of the guerrilla tactics of special militias and the colonial-tribal jirga system controlled by the malik.

In essence, the Pakistani government has kept this arrangement intact. In 1947, there was a real fear that the tribal malik would oppose the inclusion of the tribal areas into Pakistan and opt for the formation of an independent Pakhtunistan instead. Such separatist ambitions have been articulated up to the I970s and still exist today. By declaring that it would not change the special status of the tribal areas, the Pakistani state sought to prevent the tribal leaders from joining the Pakhtun nationalist movement. The continuation of the special status of the FATA was furthermore legitimised by the modernist notion - especially prevalent under the regime of Muhammad Ayub Khan (I958-I968) that the tribal population was neither interested in nor capable of the democratic rule of law.

Recently, there have been some attempts to reform the FATA's special status. Various reform committees have proposed changes in the jirga system to make its proceedings more formal, to incorporate the law of evidence and to make it more independent. As will become clear below, it has also been proposed that those traditions in the customary law system that violate individual rights, especially those of women, be removed or reformulated. The Frontier Crime Regulation (FCR) in particular has been criticised from various sides, and Prime Minister Asif Zardari has announced that he will abolish this I90I law. Some steps towards democratisation have been taken: the tribal population has been allowed to vote in national elections since 1997, although the parliament is not yet authorised to legislate for the FATA. The government of General Parvez Musharraf proposed the introduction of local government in 2002, with special seats for women in various local councils. However, the successful implementation of such reforms has been opposed and sabotaged by the malik and the state bureaucrats who work with them. Besides, the so-called war on terror has reversed this process, as the state is at present interested in strengthening its power by way of the office of the political agent rather than in democratisation and the introduction of accountability in the local political system. At the same time, the war on terror is only the latest trend in a recent history of the tribal areas being intimately connected to developments in neighbouring Afghanistan. More than three million refugees from Afghanistan have been accommodated in these areas. The region has seen large-scale militarisation, growing state interference, the intrusion of foreign aid 
and intelligence agencies, and the rise of several jihadi organisations. Some of these trends have benefited from and sustained the FATA's state of exception, whereas others have supported the demand for change and reform.

Our research on popular discontent with the FATA's special status focused on two of the tribal agencies: Khyber and Kurram. Khyber is named after the famous Khyber Pass connecting Kabul to Lahore and Delhi and largely consists of barren terrain with some fertile valleys. It is located west of Peshawar, the capital city of the North-West Frontier Province, and has a population of approximately half a million. Kurram, named after the main river, lies southwest of Khyber and is more isolated. It too has a population of approximately half a million, with a considerable Shia minority. Research in both agencies was conducted by way of group conversations and individual interviews with both men and women. The group conversations tended to be more formal in nature, whereas the interviews were of a more intimate character. Conversations and interviews were conducted by Sarfraz Khan (in the case of the men) and Samina Rehman (in the case of the women).

\section{The Maliki System}

In this section we analyse in greater detail the maliki system, the notion of tribal culture it fosters, the social and political inequalities it legitimises and its inefficiencies and excesses that have spawned the growing opposition against it. In the following sections, we will pay attention to the ways this growing opposition is framed in various discourses of licitness and legality and what alternative power arrangements they endorse.

It is by now common knowledge that the British colonial administration in the nineteenth and early twentieth century had an immense fascination with tribal culture and tribal politics. A substantial part of the British tradition of social anthropology has developed in tandem with this colonial interest. Many anthropologists working on tribal societies not only in Afghanistan and present-day Pakistan but also in the Middle East or Africa - have been interested in questions of political leadership in what was generally considered acephalous societies. According to this body of knowledge, tribal societies are organised according to a system of segmentation (Evans-Pritchard 1940); each segment is essentially autonomous, forming temporary alliances on the basis of equality but separated from other segments by an ideology of independence. At the same time, tribal society is highly patriarchal, generating heads of families, clans and sub-tribes who act like patrons to those who fall under their protection and like potential warlords to outsiders. When former 
British social anthropologists and colonial administrators talked about tribal leaders, they essentially had the patriarchal representatives of such tribal segments in mind.

The assumption that tribal societies were basically stateless ones has been criticised since then as a historical error and a reflection of the political bias of the British colonial enterprise (Asad 1972; Gilsenan I996). While the tribe can be taken as a technical definition of a group with a headman who is only the first among peers, in its Orientalist effort, the colonial anthropological discourse readily ascribed this political structure to many social groups that did not necessarily and completely fit the definition. There was particularly little attention for both royalty and religious leadership in such analyses because these political institutions did not fit well with the segmentary, acephalous character ascribed to tribal societies. Anthropological accounts of tribal societies tended to ignore the fact that the absence of kingdoms was the result of colonial conquest, which had often dethroned kings, rather than an intrinsic part of the political organisation of tribal societies. The history of today's FATA is a case in point, as large parts of it used to be part of the Afghan emirate prior to the British occupation by indirect rule. Insofar as colonial understandings of tribal society acknowledged the existence of religious leadership at all, it was widely discredited as irrelevant and fanatical; hence the colonial notion of the mad mullah or intolerant jihad. In his famous monograph on the Swat Pathans, Fredrik Barth, for instance, paid relatively little attention to religious leaders such as the saypid (Barth I959). Ernest Gellner, in his book on Morocco, did distinguish between religious leaders and tribal leaders but, following the segmentary logic, introduced the notion that religious leaders could only rise to power in times of crisis or outside threats, whereas in 'normal' times their position was a marginal one compared to those of the tribal leaders (Gellner 1969). Olivier Roy has reiterated this analysis in his book on the Afghan resistance (mujahideen) against Soviet occupation, explaining the fragmentation of the Afghan resistance in the I980s on the basis of tribal competition between various warlords, concealed by the feeble ideology of Islamic solidarity (Roy I986). If Muslim tribal society was in principle believed to be capable of two kinds of warfare - the religious jihad against the foreign infidel and the tribal conflicts in defence of autonomy - it was the latter that was taken to be much more common and characteristic for tribal political culture.

Although it would perhaps go too far to call Western knowledge about tribal culture purely fictitious, it was surely one-sided. As the dominant perspective behind colonial policy, however, it did influence and change the power structure in tribal societies. Identified as the main power brokers, tribal leaders were seen as the most natural 
representatives of society at large and therefore the most obvious party to deal with. In that sense, colonial occupations significantly restructured the political organisation of tribal societies. In the tribal agencies along the Afghan border, the power and status of the malik increased considerably during the colonial period and even after that. The malik represents his clan (khel) in the sarkari jirga. He deals with the political agent and his assistants with regard to development projects such as irrigation, infrastructure, education and health. He decides about jobs in the gradually expanding state apparatus in the tribal areas (development schemes, local bureaucracy), which are in high demand because of the difficulty of making a living in agriculture, traditionally the most important employer in the tribal areas. There are few legal alternatives, as loans to set up private businesses are hard to get for the inhabitants of the tribal areas, and businesspeople from outside the tribal areas do not consider the region safe enough for investments. Government jobs, therefore, are a precious scarcity in the tribal areas, even more so than elsewhere in Pakistan, and their monopoly position regarding these jobs significantly adds to the malik's power, status and wealth. Accusations of corruption and bribery, however, are also increasing, enhancing the notion of the malik as peons of politicians and bureaucrats and their reputation as stooges and informers of foreign colonial rulers. The fact that today many malik are absentee landlords, spending most of their time outside the tribal areas in the affluent city neighbourhoods of Peshawar or Islamabad, adds to the impression of moral corruption.

The malik have a powerful position within the backbone of the legal system within the tribal areas: the sarkari jirga. The prefix sarkari (or 'of the government') already conveys an implicit critique of the institution, as it is opposed to the ulasi or 'people's' jirga. Nonetheless, the institution of the jirga as such is seen as an important element of traditional tribal culture by virtually everybody in and outside the FATA, including those who are critical of tribal culture such as modernists and Islamists. The jirga is taken to be a crucial part of customary law, which does not recognise a neutral arbiter like a judge or a jury; it is rather a roundtable conference of sorts, a conversation among equals that reaches an agreement on the basis of social convention. The institution is said to express a tribal form of egalitarianism that differs from the egalitarianism of the modern legal system in that it does not delegate the authority of the people to a blind court. Like tribal culture, the jirga is sometimes called a form of primitive - perhaps even pure - democracy.

The reality, however, is slightly more complicated. The sarkari jirga is called a government's jirga because its members are appointed by the political agent of the agency. Its task is to decide on criminal cases and to report its verdict to the political agent. In principle, anyone can lodge a complaint with the political agent, after which the jirga will convene at 
the place of the aggrieved party. The latter is supposed to host the members of the jirga during the time of the meeting, which makes it a costly - sometimes too costly - affair for the complaining party. The women of the house are supposed to prepare large quantities of food, the failure of which will be interpreted as a lack of tribal hospitality. This makes it unattractive, sometimes even impossible, to call for a jirga. Besides, jirga members are said to be easy to bribe. Their links with the political agent and its bureaucrats are also believed to harm their independence. Jirga members and bureaucrats are all said to be involved in illegal activities such as smuggling, car lifting, forging documents or printing fake currency notes - either actively or passively by turning a blind eye to the activities of illegal organisations. To a considerable extent, the tribal areas function as a safe haven for illegal activities. Cars that are stolen in Peshawar or Islamabad, for instance, are taken to the FATA and return from there with fake number plates, to be sold as new. Such activities are believed to take place under the malik's protection. Rumours about their involvement in criminal activities harm their reputation of independence. As a result, tribal justice is not only beyond the means of the poorer segments of the population, its impartiality is also seriously contested.

In this context, the prefix sarkari is not simply a designation of its place in the FATA's legal system. Sarkari is today better translated as 'not-of-the-people' and illegitimate. In contrast, the ulasi or people's jirga is a gathering of locals discussing matters of a village or a clan. Such meetings, which have no formal authority, are generally considered just and efficient ways of dealing with disputes and complaints. Alternatively, there is the maraka (gathering in a mosque) or imam bargah, where representatives of the village families discuss collective issues.

The special status of the FATA, including the jirga system, is based on a notion of tribal culture generally known as pakhtunwali (or the ways of the Pakhtun). There is, however, considerable disagreement about what exactly constitutes pakhtunwali. It is a concept broad enough to include a range of cultural notions such as chagha (the collective responsibility of fellow tribesmen to support each other in cases of blood feuds), pagar (a similar responsibility to collectively cooperate in economic matters such as harvesting), melmastia (hospitality), panah (the responsibility to protect guests like one's family members), khegara (solidarity), nang (the responsibility to protect one's independence and respect somebody else's), badal (the obligation to take revenge for assaults on one's independence or honour), ghairat and tura (honourable, courageous conduct) in some situations, and nanawati (humbleness) in others. Sometimes, pakhtunwali is said to include a man's right to carry arms. With the widespread availability of firearms since the Afghan wars, this has indeed become a widespread custom and a right. For 
others, pakhtunwali also includes jihad or the right to trade freely in arms and narcotics. Some would mention the notion of pat (shame) and purdah (seclusion of women), or even swara (child marriage) and the payment of bride prices. The seclusion of women in particular, as well as the notions of honour and independence connected to it, is often said to justify the FATA's exceptional legal system. The modern court system would send a convicted woman to jail, whereas the combined values of purdah and badal require that the woman be punished by her own relatives. Allowing a woman to go to jail would harm the honour of her kin and clan. Few of the so-called tribal customs, however, are beyond dispute, and their interpretation often changes.

It will not come as a surprise that the Pakistani state has largely supported the maliki system and endorsed an interpretation of pakhtunwali that sanctions the special status. As already indicated above, however, it has at times also responded to calls for reform. Besides, over the last three decades it has also given considerable support to Islamist militias, first during the time of the Afghan resistance, and later in organising the Taliban or organisations operative in Kashmir. By doing so, however, the state has given support to an ideology that is largely critical of the notion of tribal culture. Islamism seeks to reform pakhtunwali along more orthodox Islamic lines. This is the first and, to some extent, most powerful critique of the maliki system that we will discuss.

\section{Jihad and Reform}

Whereas the Afghan-Pakistani border region is now considered a hotbed of the most zealous and militant forms of Islam one can imagine, it is perhaps necessary to point out that the kind of Islam associated with Al Qaeda, the mujahideen or the Taliban is a rather recent invention, directly related to the Afghan wars that started in I978. The more traditional, custom-laden Islam that was common prior to the I980s - and that continues to exist today - revolves around the village mosque and the shrines (dargah) of local holy men. Visiting shrines is still a major form of recreation for the women in Khyber and Kurram, although watching TV has become a powerful alternative. For many men, the daily visit to the village mosque is the most enduring aspect of their religious life. As Magnus Marsden (2005) has shown for the nearby valley of Chitral, such practices are not only surprisingly immune to aggressive reform, they are also a self-conscious if implicit critique of highly politicised interpretations of Islam, for which many have used the term Islamism.

The Islamism in the FATA is a mix of South Asian reform traditions, usually referred to as Deobandi, and Salafi and Wahhabi influences 
from abroad. They all tend to promote an inner-worldly form of Islam, seen as a permanent revolution (inqilab) against ignorance (jahilliyya) and moral corruption. Within that field, however, one also finds many disputes and disagreements. For our purposes, the main distinction is the one between the mujahideen and the Taliban, the latter being divided into Afghan and Pakistani branches. The mujahideen are the older of the two, originating in the I980s as a number of resistance armies that fought against Soviet occupation. The history of the mujahideen has been written extensively (Roy I986) and will not be repeated here; what is important in our context is their perspective on tribal culture. Insofar as the mujahideen were Pakhtun, they tended to reformulate rather than transcend pakhtunwali. They were to some extent inspired by the notion of jihad, but interpreted this type of warfare as part of Pakhtun culture and history rather than as an alternative to and a critique of pakhtunwali. As already mentioned earlier, this led Olivier Roy to conclude that their position was comparable, albeit not similar, to the place of sayyid, who in former times could call for a jihad that would unite all tribal leaders for the time of the holy war, without fundamentally harming the tribal political structure.

The Taliban, however, are much more radical and modernist in their rejection of traditional tribal culture. They tend to see tribalism as opposed to Islam and reject a number of tribal customs as un-Islamic. Most well known, perhaps, is the Taliban's condemnation of sexual relations with young, 'beardless' boys. Although of course not officially endorsed as part of tribal culture, some mujahideen quite openly saw a link between their skills as warlords and their libido for young men, thereby adding to the already existing popular notion of the Pakhtun as a sexually promiscuous lot. For the Taliban, such liaisons were as morally offensive and un-Islamic as extramarital relations between a man and a woman. The Taliban also seeks to abolish tribal customs that people would more readily recognise as part of pakhtunwali, as we will show below.

Whereas the Afghan Taliban's original raison d'être lies in its opposition to the mujahideen in the mid-I99os, the Pakistani Taliban is primarily a response to the war on terror and the Pakistani state's operation against Islamist militias in tribal agencies like South Waziristan. The umbrella organisation known as the Tehrik-i-Taliban Pakistan (TTP) was formed in December 2007 in a meeting of Taliban commanders from various tribal areas. It has managed to take control of areas such as Bajaur and Swat. Ideologically, it is concerned with introducing the shariat in Pakistan, starting with the replacement of the maliki system in the tribal areas. In doing so, they reiterate the anti-mujahideen ideology of the Afghan Taliban. Within the Pakistani Taliban, discussions about jihad, for instance, include the question of whether fighting a mujahid 
can be considered a form of jihad. They are as hostile to traditional tribal leaders as they are to Pakistani state officials or the former mujahideen. Like the Taliban in Afghanistan, they are also notoriously anti-Shia.

Apart from the war on terror which is to a considerable extent fought out in the tribal areas, there are other reasons for the rise of Islamist organisations. They tend to be attractive to young men who do not feel represented in the maliki system. There is no place for them in the sarkari jirga - nor in the ulasi jirga for that matter. The growing significance of Islam as a language of protest is also due to the fact that the mosque and the madrasa are the only places where people are allowed to come together and discuss political or social issues. In that sense, Islamism can be seen as an extreme response to an extremely antidemocratic situation. That, however, does not mean that the local population supports Islamist organisations in large numbers. In Khyber, for instance, the most powerful Islamist militia since 2004 is the Lashkar-iIslam led by Mangal Bagh. Exiled from Kurram agency by tribal leaders for inciting anti-Shia hostility, he has been campaigning - both as a journalist on his own radio station and as a paramilitary leader - to promote a Deobandi version of Islam in Khyber, which brought him in violent conflict with more traditional Barelwi religious leaders as well as the political administration. It is not uncommon for the local population to describe his efforts as goonda raj, or the rule of thugs.

Islamist leaders like Mangal Bagh and others are vigorously opposed to the power of the malik as well as to customs that they consider antiIslamic. In Khyber, for instance, the Lashkar-i-Islam has abolished and punished practices like child marriage (swara) and the payment of bride prices in the areas it controls. These practices are seen as selling one's daughter, which to them is not allowed in Islam. Lashkar has also criticised the tribal customs that prevent women from inheriting property. Because women potentially marry into another clan, the property that they own would automatically be transferred to the other party, which is why women in the FATA normally do not own land or material goods. Islamist parties have opposed this with reference to the holy Koran. Honour killings have been criticised for the same reasons. At the same time, Islamist parties are vigorously opposed to what they perceive as immoral behaviour like gambling, watching television or listening to music. They are also in favour of the strict seclusion of women from the public domain (purdah).

Politically speaking, the Islamist organisations tend to consist of relatively young men from tribal areas who are critical of the maliki system, which they consider to be morally corrupt and politically discredited (Abbas 2008). For them, it is no solution to abolish the state of exception, introduce the rule of law and bring the region under the legislation of the national parliament and provincial assembly, because they 
do not accept the authority of the Pakistani state either. They tend to see the maliki system as an illegal extension of the corrupt political system in Islamabad. Their solution is the introduction of the shariat, which would potentially put an end to political privileges that are legitimised with reference to tribal egalitarianism, possibly give women more rights in terms of marriage and property, almost certainly endorse an ultra-conservative take on moral issues and probably classify Shias as non-Muslims.

\section{A Different Kind of Tribal Culture}

Whereas the maliki system and Islamism of various sorts are highly ideological, based respectively on a conservative notion of tribal culture and reformist Islam, neither of them addresses the poor state of the economy in the FATA in any persistent manner. The maliki system is officially responsible for development schemes meant to improve the local economy and introduce basic services but is widely involved in nepotism, bribery, smuggling and other illegal activities that keep socialeconomic inequalities intact. Islamist organisations are primarily concerned with moral issues. The two discourses we will discuss in this and the following section do, however, take social inequality and lack of development as a starting point. Both the renewed formulation of Pakhtun nationalism and the language of human rights claim to be driven primarily by an agenda of social change and improvement.

The tribal economy is, indeed, in bad shape. And so is the provision of services like clean water supply, electricity, natural gas, health care, education and infrastructure. The legal trade with neighbouring Afghanistan has suffered from decades of war. Whereas the tribal areas accommodated up to three million Afghan refugees in the I980s, many young men from the FATA now cross the border to find employment in Afghanistan because there is none at home. Others work as migrant labourers in the Gulf. As already mentioned, banks are very reluctant to offer credit facilities to the FATA population because the state has no authority to recover the bank's money in the case of a failed investment. Only if two members of a sarkari jirga furnish surety are banks sometimes willing to give loans, a practice that increases the power position of the malik. Because of the lack of new irrigation schemes, agriculture is not capable of employing a large number of people. In fact, families sometimes sell their land to members of other tribes or clans and give up on agriculture. Petty trade and transport, along with illegal economic activities like smuggling, are the main economic assets.

Another issue on the social agenda is the position of women in the tribal areas. There is growing opposition - both from NGOs and local 
women themselves - to the subordinate role that women have in tribal society. Women embody the vulnerability of a family's or clan's independence and reputation and therefore play a minor role in public life, if at all. We have already seen that they do not normally own or inherit property. The custom to pay a bride price (volvor) - that is, a payment to the family of the bride by the family of the groom - is condemned not just for Islamic reasons but also because it establishes the status of the bride as property of her husband. The opposite custom of dowry - that is, an amount of money or property the bride brings with her into the marriage - usually gives her a relatively more independent position, because the dowry ideally remains her property and she will take it with her in case of a divorce. Although in some recent cases, bride prices have been replaced by dowries, the former is far more common in the tribal areas. It is practically impossible for women to divorce, and when her husband decides to divorce her, her children stay with the husband's family. Women complain about domestic violence and the refusal of the sarkari jirga to address such issues on the basis that domestic violence is a family matter and therefore beyond the jurisdiction of the jirga. Besides, the practice of punishing honour crimes much more mildly than homicide related to economic or political disputes makes women vulnerable; sometimes a woman is murdered along with an economic competitor or political opponent to make the crime look like an honour killing. In some cases, women have learned to use firearms to protect themselves, especially if a large number of the male's family members work abroad as migrant labourers.

Some women in Khyber and Kurram, however, also report some positive changes. Although they are not represented in the sarkari jirga, they do have the right to vote since I997. In the 2002 proposal to set up local government bodies to which the political agent will be accountable, such bodies will have some seats reserved for women. There is also a general impression that domestic violence is decreasing. More women go to school or have jobs outside the house than previously, although female employment and literacy remains very low. Some women say that they benefit from the fact that more and more men receive higher education in Peshawar or elsewhere, because they return with more liberal ideas about gender roles. Educated boys, they say, want educated brides. It is quite common for women to use contraceptives, which makes their role as mother less burdensome.

Benedicte Grima (2005) has pointed out the common practice among women of sharing their despondency (gham) with other women in rituals that establish social relationships and confirm their status as women of honour, a practice comparable to the poetry of Bedouin women in Egypt analysed by Lila Abu Lughod (I986). Whereas in Grima's analysis, these social expressions of misery primarily function 
as the female equivalent of male honour and therefore help maintain existing gender roles, the women's voice has also become more political recently. Especially younger women are critical about both the maliki system and the Islamist alternative. The latter, they feel, would lock them up, deprive them of the possibilities to work outside the house and take away their TV sets and satellite dishes. But they also contest the authority of the maliki system and the almost unbridled power of the political agent. As several women interviewed for this project said: 'The PA (political agent) is like a king' - a comment meant to be critical. They also disagree with the fact that women have no say in the sarkari jirga. To be sure, however, some women articulate much more conservative opinions. Especially older women complain about the lack of modesty of the younger generation of women.

It is not just women who oppose traditional tribal customs felt to be discriminatory to them. They also find themselves in coalition with leftleaning professionals, journalists, academics, social workers, politicians and others who demand the replacement of the maliki system with a more decentralised and grassroots form of tribal democracy. They reformulate tribal culture and pakhtunwali more in terms of solidarity (khegara) and mutual responsibility (pagar). They translate the notion of tribal independence in nationalist terms as Pakhtun autonomy. This is, in fact, an old discourse, quite powerful prior to the Afghan wars and the rise of the mujahideen. The Awami National Party (ANP), originally a left-wing Pakhtun nationalist party, represents this position within the political spectrum of the North-West Frontier Province and national politics. To be sure, the notion of Pakhtun autonomy does not necessarily entail a separatist demand for an independent Pakhtunistan; it is better understood as a form of ethnic nationalism found elsewhere in Pakistan, where ethnic parties like the Muhajir Qaumi Movement (MQM) or some Sindhi or Baluchi parties demand a bigger share of the national resources for the ethnic group they claim to represent. The ANP, for instance, does not demand full autonomy for the Pakhtun. Rather, they work for a more powerful Pakhtun province, to be renamed as Pakhtunkhwa - the preferred name for what is now known as the North-West Frontier Province, clearly a colonial name - and which will also include the tribal areas. The Pakhtun nationalist position, in other words, is in favour of abolishing the state of exception in the FATA. Historically, Pakhtun nationalism sees itself standing in the tradition of Khan Abdul Ghaffar Khan, the leader of the non-violent independence movement in the North-West Frontier Province. 


\section{Civilisation and Human Rights}

We will lastly discuss another discursive tradition that opposes the conservative notion of tribal culture, which is somewhat akin to the Pakhtun nationalist one we have just mentioned. Its main concern is with development, social equality, an improvement of the economy, progress, women's emancipation and the position of minorities like the Shias. The difference, however, is the discursive emphasis on universal civilisation and human rights rather than ethnicity and pakhtunwali. The state of exception of the FATA, in other words, is condemned because it violates some basic human rights, primarily translated as a sense of autonomy for women, the right to democratic participation and access to the High and Supreme Courts. Human rights are seen as an expression of some basic human civilisation that is not unique to any particular society or religion. Civilisation used in this sense has nothing to do with prefixes like Western, Islamic or South Asian. Its universalism, however, has a particularly strong modernist influence, articulated for instance in its clear focus on education. There is a firm belief that formal education brings about a civilised attitude that is opposed to, for instance, tribal gender ideology, honour killings or customary law. It is partly for this reason that the civilisationalist discourse stresses the importance of female education, for education makes for better mothers, and better - that is, more civilised - mothers are the starting point of all positive change.

The civilisationalist discourse is attractive for those who are more radically critical about tribal gender ideology and family organisation than the Pakhtunkhwa position described above. Particularly the legitimisation of honour killings and child marriage with reference to tribal customs is seen as backward, as is the practice of veiling and polygamy. The difference with the nationalist discourse is that nationalists do not consider such practices essentially Pakhtun. Instead, they define pakhtunwali in terms of egalitarianism and solidarity. For civilisationalists and modernists, however, these 'backward' practices are intrinsically part of tribal culture. One woman in Kurram, for instance, described pakhtunwali as essentially a strict obedience to tradition and tribal elders. Some of these traditions, she said, were positive, others negative, but the notion of uncritical obedience made it impossible to discriminate between them. Even in order to retain positive tribal customs, therefore, the basics of tribal ideology had to be changed. For another woman, a resident of the Khyber agency, the province of the Punjab was an ideal place of progress and prosperity, which, she felt, was largely the result of the fact that the Punjabis had left behind their tribal customs a long time ago. 
The modernist position is critical of the FATA's special status and demands that the tribal areas be merged with Pakistan and become full participants in national and provincial politics. It primarily stresses the need to abolish the Frontier Crime Regulation and wants to extend the jurisdiction of the Supreme and High Courts to the tribal areas. It also advocates the introduction of a modern education system. These demands are put forward not in the name of Islam or a reformulated tribal culture but in the name of civilisation and human rights.

\section{Conclusion}

In this chapter, we have described four discursive traditions related to political legitimacy in the tribal areas: I) a conservative, largely colonial notion of tribal culture, 2) an Islamist critique, 3) a redefinition of tribal culture in progressive and nationalist terms and 4) a modernist emphasis on human civilisation. We want to stress that these four are, indeed, discursive categories, not sociological ones. That means that none of these discourses can be ascribed to a particular social or political group, even though they do challenge certain power positions and legitimise others. They should rather be seen as possibilities or positions from which one can engage in a field of political contestation. That also means that it is possible for one and the same actor to switch from one position to another, or to combine elements from several discourses to make an original argument. To do so requires a level of multiple discursive competence (Baumann I996) necessary to creatively borrow from several discursive traditions in a meaningful way.

This, however, does not mean that all traditions can easily be combined. Some combinations are much more common than others. We have for instance found that, despite obvious differences, elements from the Islamist discourse often mix with elements from the modernist discourse. What they have in common, of course, is a radical critique of tribal culture as such. It is also striking to see that young men often easily move from radical Islamism to radical modernism. One of our informants, for instance, is a student and a private school teacher, as well as a local reporter for an Urdu newspaper. As a pupil of a madrassa in Landikotal, near the Khyber Pass, he became a member of the militant Harkat-ul-Mujahideen. He underwent tough military training in Kashmir. He left the organisation after some time and is now against any kind of politics or activism that is based on either religion or tribal culture. He promotes education and health facilities for both men and women, is as critical of the maliki system as he is about militant Islamist groups, and wants the tribal areas to be part of the Pakistani federation rather than of a Pakhtunkhwa province. Another example 
involves an ex-student from Jamrud College, west of Peshawar, who owns a medical store, writes poems and plays volleyball. He used to be an active member of the Tablighi Jamiat, a missionary movement, because he felt the inhabitants of the tribal areas adhered to tribalism rather than Islam. But he also condemns Islamist groups for their conservatism on moral issues and the Pakistani state for being corrupt, and believes that only a powerful and authoritarian secular modernisation can bring progress to the tribal areas.

We also found other discursive amalgamations. An obvious combination, already hinted at above, is the mixture of progressive Pakhtun nationalism and modernism, as both are critical of conservative tribalism and radical Islamism, and both favour developmental issues instead. It is also not uncommon for someone to position himself halfway in between the conservative and progressive definition of tribal culture - for instance by those who want to reform rather than abolish the mali$k i$ system. Modernist arguments, although often critical about the status quo, can also be used to legitimise the state of exception, for instance when arguing that the local population is not yet educated enough for full political participation. Islamism and conservative tribalism have been combined quite extensively by the former mujahideen in the Afghan wars, for whom jihad was a tribal custom. Much rarer, however, is a combination of Islamism and progressive nationalism.

We finally want to stress that, despite the violent and often deadly nature of these conflicts and the involvement of many foreign influences in them, these contestations take place among and between groups of people who know and understand each other's arguments. It is, in other words, not a fight between foreigners not speaking each other's ideological language. The tribal areas differ from other areas ruled by the state of exception - Gaza or Guantanamo Bay are recent examples - in that it is domestic territory; although outside the state jurisdiction, the tribal areas are not considered foreign soil. This makes it unclear what the status of the local population is. As people born and bred on Pakistani soil, they can be considered Pakistani citizens; as the population of tribal areas, they are considered free tribes and therefore not citizens. They are also Pakhtun, which can be translated as 'a member of an ethnic group in Pakistan' or 'a member of a nation without a state', like the Kurds. Besides, they are Muslims, which can have various meanings, too - from 'a Pakhtun' or 'a Pakistani citizen' to 'a member of a beleaguered umma'. Being a Muslim can also have a more secular or private meaning. No term of identification has a fixed meaning, but there is some consensus as to what the key terms are in these conflicts, and it is around these key terms - Islam, Pakhtun ethnicity, Pakistan, modernity - that the conflicts revolve. 


\section{Note}

I This work is part of the 'Illegal but Licit' research programme, which is financed by the Netherlands Organisation for Scientific Research (NWO). 


\title{
3 'Looking for a Life'
}

\section{Rohingya Refugee Migration in the Post-Imperial Age}

\author{
Diana Wong and Tan Pok Suan
}

\section{Introduction}

A refugee, according to Hannah Arendt, was a person who had no right to rights. Her statement was based on her own experience during the Nazi period of being stripped of German citizenship because she was a Jew. This definition of a refugee no longer holds true. In no small measure due to the lessons learned from that experience, a refugee rights regime - flawed and inadequate though it may be - has been established both at the transnational level and, in many Western liberal states, at the national level. This has enabled and legitimised substantial refugee flows and resettlements in the second half of the twentieth century. Less well known, however, are the substantial population displacements and settlements that are illicit and outside of any formal regulatory framework, which have been sustained not by the assertion of civil rights but by the 'paper citizenship' of weak states (Sadiq 2008) and the conditional 'hospitality' of shared cultural vernaculars. ${ }^{\text {' }}$

In this paper, we draw on ethnographic fieldwork and interviews with a refugee group in Malaysia - the Muslim Rohingyas from the province of Arakan in Burma - to make the following arguments. Far from there being a unified and homogenous space of global or transnational migration, represented by the contemporary Western European (and/or US) experience, it would be more appropriate to think of contemporary patterns and practices of border-crossing migration in terms of 'imagined worlds' (Appadurai I990) or 'overlapping zones' (Balibar 2003). Bowen (2004) has recently argued for the existence of a discursively constituted 'transnational Islamic space'. The information gleaned from our interviews with the Rohingya points to the existence of a contemporary transnational Islamic space or zone of migration governed by the practices of illiberal states and shared Muslim hospitality, and of a Muslim migrant world dwelling therein in the interstices of the illegal and the licit. 
At the same time, Rohingyas are 'persons of concern' to the United National High Commissioner for Refugees (UNHCR) and thus clients of a transnational human rights regime. This regime, anchored in the legal norms of the Western liberal state, with its validation of refugees as a legal category, does confer some degree of state-transcending protection to extra-territorial populations that fall under its care. The second argument made in this paper concerns the pattern of mobility that the morphology of refugee migration entails. Whereas the prevailing image surrounding the refugee is that of immobility (as in the Agamben trope of the camp) in contrast to the mobility of the labour migrant, we argue, based on the Malaysian material, that the obverse can also be true.

The standard distinction between the migrant and the refugee in terms of personal motivation (voluntary versus forced) is one designed purely for the purposes of the asylum-granting state. This distinction is an instrument for the conferment of legal or illegal status by the state and is conceptually flawed when trying to understand contemporary migration flows, which are generally mixed in character. What could be of analytical value, however, is a distinction between refugees and labour migration defined primarily, though not entirely, by their specific regulatory regimes. Whereas refugee migration is in large part politically driven and (partially) subject to a transnational regulatory regime, labour migration is market-driven and subject to the regulatory regime of the nation-state.

Since the termination of the guest worker programmes in the Western European states in the mid-I970s, organised legal labour migration in the form of Temporary Foreign Labour Programmes (TFLP) has shifted to destination countries in the Middle East and Southeast and East Asia. In these countries, the rotational principle is strictly maintained and enforced, and settlement and family reunion is not permitted. The result is the establishment of transnational migration corridors with a stable two-way flow of entry and return of successive generations of migrants. Mobility and settlement outside of this narrow trans-border corridor is limited.

The refugee form of migration appears to result in quite a different morphology. As Zolberg has pointed out, refugee migration is not market-driven, although refugees do end up as economic migrants in the labour market; it is the result of 'refugee-generating states' (Zolberg I983). As a consequence, return is difficult, thus hampering the emergence of the transnational corridor so typical of labour migration. On the other hand, thanks largely to the transnational refugee regime established since the end of World War II and expanded since the I978 Indochinese refugee crisis, refugee displacement has been subject to a more complex spatial architecture, including the possibility and practice 
of resettlement in so-called third countries in the West. For displaced Muslim populations, there is also an extensive Islamic zone of migration, as argued below. Large diasporas of far-flung but closely networked communities are the result. Compared with the tightly controlled corridor space of labour diasporas, the diasporic space generated by refugee migration provides for a high level of mobility for those plugged into its variegated web.

\section{Migration in the Post-Imperial Age}

Massive movements of the desperate and the despised across perilous state borders, generally known as refugee migration, were characteristic of the post-imperial age of successor nation-states in Asia. There was the partition of the Indian subcontinent, the Chinese flight to the offshore islands of Hong Kong and Taiwan, the division of the Korean peninsula, Dien Bien Phu and the creation of two Vietnams - the list could go on. The population displacements these cataclysmic state-making events generated were far from limited. Other than on the scarred victims and the internal constitution of the new nation-states, however, they left few traces on the international politics or the international academic literature of the day.

In Asia, newly minted post-colonial states were often inheritors of highly heterodox populations which the vast migrations unleashed by the capitalism of the imperial age had flung together. They were also, as nationalist claimants to the state, true believers in the anti-imperial notion of the territorially sovereign nation-state. One of the first acts of these new states was to put in place the state infrastructure - legal, administrative and policing - necessary for the protection of their borders, many of which had previously not existed. 'Nation-building' within the limits set by these borders was the order of the day. In the ensuing decades (from the I950s to the I980s) of what now seems in retrospect a 'short' post-imperial age, the populations of these post-colonial states remained largely confined within the borders of their territorial state. With some dramatic exceptions, such as the mass migrations from Bangladesh to India in I97I and the exodus from Sri Lanka in the I980s, mobility generally took the form of internal migration, often encouraged by the state concerned but visible to no other. The age of the great tropical migrations ceased; the dust had settled, it thus appeared, on the secure borders of the post-war, post-colonial world.

In Europe, the post-imperial age was absorbed by the post-war decades of economic reconstruction and growth, albeit in the shadow cast by the Cold War. The political competition generated by this new war, however, resulted in the freezing of territorial boundaries in the 
European heartland and the immobilisation of captive populations behind that ultimate instrument of territorial and population control the Wall. This brought two centuries of constant flows and movement across and beyond the European continent, culminating in the great population displacements of the various wars of the first half of the century, to an end (Bade 2000). Post-war Western Europe had succeeded, to a large degree, in having its internal population heterogeneity cleansed and its external borders sealed. Residual colonial populations from the Empire slipped in, especially to the Netherlands and Britain, but otherwise, the doors were shut. They were reopened in the I96os only for the import of temporary guest workers from the continent's southern Mediterranean fringe, but under conditions of strict and wellmanaged legality, and as a short-term measure for the management of the labour market.

Under such circumstances, refugees and refugee migration - and indeed migration issues as a whole - remained low on the national and international political and academic agenda, relegated to a small group of specialists who were marginal to the establishments of both. Migrants and refugees, legal or illegal (this distinction did not seem to have been of much salience in an earlier time), if allowed to stay, were constituted as ethnic minorities creating 'issues' internal to the respective nation-states and their specific national policies. As such, they were blended out of view from everyone but the state concerned.

The end to this post-imperial/post-colonial/Cold War age of population immobilisation was heralded by a series of unrelated events in I974 and their aftermath. The first occurred in West Asia. The I974 oil boom and attendant economic expansion in the Arab world led in the subsequent decades to millions of foreign workers flocking to the region on a scale reminiscent of the great tropical migrations generated by the colonial capitalist expansion of an earlier age. In Europe, the hike in the price of oil brought the long period of European post-war reconstruction and economic growth to an abrupt end. In I974, the recruitment of foreign labour was suspended and the European labour market was sealed off to the legal entry of labour migrants.

The Cold War continued, however, and gained fresh impetus from the I975 fall of Saigon and the 'loss' of Vietnam. The subsequent dramatic exodus in 1978 of Indochinese 'boat people' from Soviet and China-backed Vietnam appeared to vindicate America's recently lost war. For the first time in decades, the plight and flight of refugees became a matter of 'high politics' (Suhrke I993) in the international arena. The major Western powers mobilised existing international institutions such as the UNHCR, which had been set up to deal primarily with the messy population 'leftovers' of the great European wars of the first half of the twentieth century, to provide a solution for a population 
located in what had until then been part of the imperial periphery. In an unwitting concessionary move, they also committed themselves for the first time to accepting for resettlement, on a contingent basis, refugees who came from outside the traditional European-American cultural nexus of population exchange. This was to be a fateful landmark event with profound consequences for contemporary global migration.

Western Europe had shut its doors to labour migration from its poorer southern neighbours in I974. The floodgates to migration from even further afield were pried open with this 1978 intake of Indochinese refugees, for it set the precedent for the human masses that were to follow. The fall of Saigon in I975 was not the end of the Cold War; it had merely triggered the onset of its final phase, that of proxy wars between Third World countries in the so-called Global South - Afghanistan, the Horn of Africa (Ethiopia, Eritrea, Somalia), the IranIraq war - to name but a few. These 'refugee-generating' wars (Zolberg I983) sent, for the first time since the fifteenth-century global expansion of the West, waves of human migration to the West - desperate individuals who, through the claim of asylum, wrested their right to cross borders surreptitiously and remain.

The two decades that followed thrust the question of migration onto the centre of the national agenda of various European nation-states as well as the regional European agenda. With the Schengen Treaty of 200I, the European Union became a single immigration zone with stiffer barriers to entry. This zone and its immigration practices remain nonetheless tied to the mores and norms of political liberalism, 'which afford migrants a measure of due process and equal protection' (Hollifield 2005: 29). The right to asylum, to family reunion and to the acquisition of citizenship have remained professed, if not sacrosanct, practices of the state, upheld by a strong and independent judiciary even when denied by the executive or administrative authorities. As the effectiveness of border controls - undermined in the I980s through developments for which the Western liberal nation-state had been illprepared - is gradually restored through the effectiveness of supra-state coordination, the question of population control, of those who are already within, will become the defining migration issue.

The ascendance of the refugee and labour migration issue higher in the agenda of high politics has been followed by its recent entry into the debates of high theory. Once an issue mainly of marginal interest to demographers, labour economists and social workers, the figure of the refugee (and the migrant) has advanced to paradigmatic status in the work of leading social theorists. The influential concepts of 'bare life' (Agamben I998) and 'hospitality' (Derrida 2000) come to mind. Agamben's allusion to Arendt's 'We Refugees' (Agamben I995) gestures to the centrality of this figure in contemporary social thought. 
Conceived as counter-discourses to the way the state 'sees', and frames, unwelcome refugees and migrants through the lens of its legal institutions, high theory - while offering a different political vision of the refugee to that of the state - has nonetheless accepted its basic empirical premises. Refugee migration (as illicit labour) is cast as overwhelmingly directed at Europe's fragile borders; refugees are a category distinct from economic migrants; and refugee status is seen as one of immobilisation, a reduction to 'bare life'.

\section{A Rohingya Cartography of the Islamic Zone of Migration}

In I978, some 220,000 people crossed the Burmese banks of the Naaf river into Bangladesh, followed by a second mass exodus of some 250,000 people in I99I-92 (Grundy-Warr \& Wong I997). Viewed by the Burmese state as Bangladeshi illegal immigrants and therefore denied Burmese citizenship, these Rohingyas, as they called themselves, were recognised as refugees on a prima facie basis by the state of Bangladesh. The UNHCR, which recognised them as 'persons of concern', helped maintain the refugee camps set up by the Bangladeshi government and oversaw the two repatriation programmes under which substantial numbers (I87,250 in 1979 and 230,000 in 1993) returned to Arakan. Recently, it succeeded in resettling a handful of refugees in Canada (Phiri 2008). A residual population of some 27,000 people lives in the remaining two camps (Phiri 2008). Outside of the two camps, 'an estimated 200,000 , including many repatriated refugees who then fled for a second time, have settled in precarious conditions in villages and semi-urban slums ... with little or no access to humanitarian assistance and protection' (Lewa 2008: 40).

Flight and repatriation across the border, immobilisation in camp life, or precarious existence in border settlements - such is the standard cartography of refugee mobility, focused around the one immediate border of flight, with long-distance resettlement as an exceptional, residual solution. The actual cartography of Rohingya refugee migration appears to assume quite different contours. According to our key informant, $\mathrm{MN},{ }^{2}$ they are 'all around the world':

I think the biggest population outside Burma, Arakan, is in Bangladesh. Then in Saudi Arabia. The third would be in Pakistan. Fourth, not sure.

The literature on Rohingyas is exceedingly sparse, especially with regard to the countries mentioned above, all of which are to be found in the Muslim world. To begin with, the Rohingya nationality does not exist - 
except in the records of UNHCR programmes. Outside of these programmes, sanctioned by the legal norms underpinning a transnational rights regime of extraterritorial protection, the category Rohingya has no legal purchase. Officially, they do not exist. Yet scattered sources, largely from media reports, do provide evidence to corroborate MN's account.

A recent report speaks of 'I.5 million' constituting 'a very conscious Rohingya diaspora' in exile (Perera 2008). There are 'some 350,000 Rohingyas purportedly living in Pakistan' (Nyi Nyi Kyaw 2008: 3). In Saudi Arabia, 'an estimated 500,000 Burmese, most of them Rohingya Muslims, reside in Makkah region, and most do not have contacts with their mother country and have special residential status in the kingdom' (The Daily Star, 9 August 2010).

When the major exodus across the border to Bangladesh occurred in I978 (and even earlier, in I968), not all remained immobilised within the camps, waiting for repatriation back across the border. In crossing the border to Bangladesh, the Muslim migrants from Buddhist Burma had not merely entered the territory of a foreign nation-state in which personal status is defined by that of citizenship or its absence; they had also entered an Islamic world then very much in motion.

The Islamic world had begun as a world in motion in which trade, warfare and travel were key practices (Netton I993). The contemporary period of accelerated mobility began in I974, a watershed year marking the commencement of the oil boom in the Gulf states of West Asia. Labour from all over the world poured into these population-scarce oil economies of the Arab heartland of Islam, the vast majority coming, understandably, from the world of Islam itself. First came labour from the population-rich Arab countries such as Yemen and Egypt as well as displaced Palestinian refugees. Migrants from the neighbouring Muslim states of Sudan and the African Horn were quick to follow. A little later, toward the end of the decade, Muslim populations in Asian countries - Pakistan, Bangladesh, India, Sri Lanka, Indonesia and the Philippines - started becoming absorbed into this new Islamic zone of migration.

From Bangladesh, the initial intake of 6,000 Bangladeshis occurred in 1976; within two years, the figure had risen to 22,809 (Jahan 1993). The Rohingya exodus to Bangladesh in 1978 was thus well-timed for further emigration into the wider Islamic world. As Lewa notes, 'for decades, smugglers and traffickers have sent Rohingyas to Saudi Arabia, Pakistan and the UAE where many obtained a temporary permit to stay' (Lewa 2008: 40). Our informant $\mathrm{MN}$ is more specific: 'as you know, many different governments have many different regulations' (MN, I9 December 2008). 
In Bangladesh, official refugee status meant some degree of access to English education and other services provided by the UNHCR in the refugee camps. But as refugees, they had no access to the local institutions, especially of higher learning - 'so that's why their education is not so complete, not formal' (MN, I9 December 2008). Those who moved on to Pakistan, on the other hand, were 'really fortunate'. Instead of being absorbed into a system of refugee protection, they were integrated into an existing multi-ethnic Islamic state.

The people in Pakistan are really fortunate in terms of that. Because once they got there, they made an identity card. And they could easily go to schools and start to learn, become a citizen and start to learn - in those days. From I990, it became a bit difficult. Before that, it was quite easy. We can easily say that there are a lot of educated students in Pakistan, especially in the field of Islam. We call it Maulawi alim - in English, 'Islamic scholar'. Quite a number. (MN, I9 December 2008)

This account is corroborated by a recent study on citizenship practices in Pakistan. In the late I970s, Pakistan was an Islamic state under General Zia Ul Haq. It was also a state whose very formation had been predicated on the need to provide a territorial refuge for Muslim minorities. As such, 'Pakistan was a welcoming territory for any Muslim. A preferred outcome of such laws is that the majority of the claims to Pakistani citizenship have arisen from fellow Muslims - Afghan and Bangladeshi illegal immigrants' (Sadiq 2008: I3).

Muslim identity was key to the acquisition of Pakistani citizenship, and Muslim identity was key to the construction of Rohingya identity:

Rohingyas are very religious, that's one thing I can tell you. Why? You see, from ig 68 we were persecuted. From the ig6os until now - 2008. Thirty-four years. And you cannot see anyone - after so much destruction of houses and homes, being kicked out of the country, of poverty, no education, no living standards, no hospitals, no school, nothing - I still can proudly say, not a single Rohingya has actually converted to Christianity or Hinduism. That is how strong we are. (MN, I9 December 2008)

As Muslim villagers in Arakan, where the level of participation in the national schools was low (Aye Chan 2005: 404), a rudimentary religious education in the form of recitation of the Koran was very often the only education acquired. In Pakistan, religious education was readily available and eagerly seized upon. As newly-certified citizens of the state, integration was secured through participation in the institutions of local 
Islamic society, mainly the privately-run schools for Islamic education known as madrassas.

However, many Rohingya - now armed with their new identity as Pakistani citizens - chose to join the drove of other Pakistanis then making their way to the Gulf in search of employment. By the midI980s, when this temporary migration was at its height, there were an estimated 2 million Pakistanis in the Persian Gulf states. Thanks to the oil boom, this region became, by global standards, a major zone of immigration.

The migration regimes obtaining in this migration zone differ considerably from those in the West. None of the six Gulf Cooperation Council countries have signed any of the seven international instruments related to international migration, with the exception of the 2000 Protocol against the trafficking in women and children and the 2000 Protocol against the smuggling of migrants. Hence, neither the landmark I95I Refugee Convention (ratified by I44 countries) nor the I949 ILO Convention for migrant workers (ratified by 45 countries) set binding legal norms for the administration of the large foreign populations in these countries. Saudi Arabia for example, only permitted foreigners to apply for citizenship in 2004. Second- and third-generation children of long-established immigrants are not given access to tertiary education, which is reserved for citizens. Low-skilled contract workers are recruited under a sponsorship system - the kafeel system - amenable to widespread abuse, thanks in part to systematic work-visa trading and the resulting entrenchment of migrants with an irregular status (Shah 2005).

No borders, however, need to have been illegally trespassed. Most migrants enter into illegality within the borders of the country through visa irregularities. At the heart of the Muslim world, and Muslim mobility, are the sacred cities of Mecca and Medina, open to Muslims from all over the world. Every year, over a million pilgrims perform the haj. In 20I0, the number was close to three million. Thousands more perform the umrah (the minor pilgrimage) throughout the year. In both cases, the number of over-stayers is large.

So it was for the Rohingyas. In this emerging Islamic zone of migration in the late I970s, Saudi Arabia was the preferred destination for the Rohingyas (Lewa 2008: 40), with Mecca as a primary attraction. Many in the first generation arrived with an umrah visa and remained. $\mathrm{MN}$, like so many others of the second generation, was born in Saudi Arabia. Today, he says, there are 800,000 to $\mathrm{I}, 000,000$ of 'our community' living there.

The conditions for refuge and settlement there appear to have been quite different from those in Bangladesh or Pakistan. Unlike Pakistan, there was no provision in the Saudi constitution for the acquisition of 
citizenship by foreigners. Initially, as in Bangladesh, there was prima facie recognition of refugee status with the issuance of a Rohingya Refugee Card by the Saudi authorities (MN, I9 December 2008). Unlike in Bangladesh, however, this was done without reference or recourse to the UNHCR, which has not been allowed to establish a presence in the country. Later, in I994, Rohingyas in possession of foreign passports, mostly Pakistani or Bangladeshi, were accorded regularisation of status with a temporary permit to stay (and work) (Lewa 2008), in the full knowledge that 'paper citizenship' was a common practice on the Asian sub-continent (Sadiq 2008).

However, while no formal recognition was given to Rohingya nationality, the large Rohingya population in the country was clearly encouraged to organise itself as a self-administering community.

What they did was, they took some help from the government, and they opened their own schools only for Rohingya students, but using the syllabus of Saudi Arabian schools. So I'm also one of these students. We have so many schools there. These schools are fully, purely, for Rohingyas basically. There are no other nationalities at all. There are many schools like that. In the hundreds, not in tens or twenties. Almost every town has more than fifteen to twenty schools, every school has more than a few thousand students, and all of them are Rohingya. How they do it is that we have some top leaders, and they communicate with the government, and the government provides the funds for the books and the staff - a kind of charity. (MN, I9 December 2008)

The charity remains ambiguous and conditional. Those without papers are often raided and deported, with exceptional brutality displayed. ${ }^{3}$ Those with (false) papers are still without citizenship and hence with no official access to tertiary education, land or commerce. Life remains precarious.

\section{Rohingyas in Malaysia: Between Protection and Illegality}

Before Rohingyas became refugees en masse in 1978, there were already some who travelled to the neighbouring Muslim world - as pilgrims, traders, religious students - but they were few and far between. The solitary few who left often never returned, merging into the local Muslim society they visited - such as the 9o-year old father of one of our informants, who had been in Malaysia for over 50 years.

A Rohingya presence in Malaysia emerged with the 1978 exodus. Most Rohingyas living in Kuala Lumpur today, however, came much 
later - in I992, in conjunction with the second mass exodus out of Arakan (Tan 2008: 47). Apprised while in Bangladesh of this (cheaper) alternative to Pakistan and Saudi Arabia by the smuggling networks, the subsequent chain migration (also organised by smuggling networks) led to the establishment of a sizeable Rohingya population in Kuala Lumpur (a figure of I5,000 to 30,000 is often quoted by informants). The official 2007 figure registered with the UNHCR is II,277, of whom 23 per cent are women and 16 per cent children.

In a new policy initiative, the Malaysian state began registering Rohingyas in August 2006 for temporary work permits (known officially as IMM I3 permits). Since then, Malaysia has been turned into a 'primary destination' (Lewa 2008: 40).

Although the process was soon suspended due to allegations of fraud, rumours of registration and job opportunities in a booming economic environment spread like wildfire among Rohingyas in North Arakan and Bangladesh. Local smuggling and recruiting networks in North Arakan and Bangladesh swiftly emerged. Two deals are offered to prospective candidates: sea passage to the shores of southern Thailand for less than US\$ 300 or an all-inclusive package up to the final destination in Malaysia for between \$700 and \$ I,000. (Lewa 2008: 40)

Those who cannot afford to pay US\$ I,০oo have to settle for the cheaper but more dangerous sea passage. It is this recent wave that has earned the Rohingyas - 'Myanmar's forgotten people' (Nyi Nyi Kyaw 2008) - some political and media attention and the epithet 'Asia's new boat people' (Lewa 2008). However, unlike the I978 exodus of the Indochinese boat people which galvanised the international community' into action, this Rohingya attempt at escape will leave little trace on international politics or international migration patterns. Notwithstanding current attempts to address the issue at the ASEAN level, the Rohingyas must continue to rely on smuggling networks to bring them to other territorial and socio-legal spaces in which a new existence - individual and collective - can be wrung out of the vagaries of national and international law and the ambivalent hospitality of local societies. We shall use the stories of three Rohingya religious teachers, or ustaz, all registered with the UNHCR in Kuala Lumpur as 'persons of concern', to illustrate the texture of this existence.

Ustaz A (hereafter 'A') was born in I967 in Akyab, the capital city of Arakan. He became a Hafiz (a title for the ability to recite the entire Koran by heart) by the age of $\mathrm{I} 3$ and had his subsequent religious education in Chittagong in Bangladesh. He then returned to Akyab and 
worked as a mosque imam and taught at a local religious school before fleeing to Malaysia via Thailand in 1994 .

'A' first survived by tutoring the children of local Malay families in Koranic recitation. Due to constant harassment by immigration authorities, he went to work on a construction site, as illegal migrant workers there pay 'protection money' on a monthly basis to the local police beat to ward off raids and detentions. His wife and son subsequently joined him from Arakan, but his wife, unable to cope with a life of constant insecurity, returned to Arakan. In 2005, 'A' married a Rohingya woman in Kuala Lumpur who had lost touch with her husband ever since his detention by Malaysian immigration authorities several years ago.

'A' became a highly regarded 'elder' of the Rohingyas in Kuala Lumpur and helped found the Rohingya Ulama Council in 2005. In 2008, he and his family were finally able to leave Malaysia for resettlement in Sweden under a UNHCR programme. A total of 45 Rohingya individuals/families have been resettled from Malaysia since 2007 (United States Committee for Refugees and Immigrants I999).

Ustaz F, having lived here for nineteen years, appears to have decided to settle in Malaysia. Born in I968 in Maungdaw, a town bordering Bangladesh, ' $F$ ' studied at the local madrassa from age five to seventeen. In I985, after having participated in a student demonstration, he fled to Bangladesh and worked there for five years before returning to Maungdaw in I990. When he decided to leave again together with a fellow villager, this time it was to head for Malaysia.

A chance meeting with an old Malay couple led to an invitation to teach their grandchildren the Koranic recitation. He stayed with them for a while before moving to the southern state of Johore, where he first met an Urdu-speaking Malaysian Indian who helped him find a job, and then a local Malay ustaz whose tenant he became for two years. This family, with whom he developed a close relationship, subsequently arranged a marriage for him with a local Malay girl. The two children who issued from the marriage remained with their mother when it ended in divorce ten years later.

' $F$ ' has worked in a variety of jobs in Malaysia - as a factory worker, security guard, store assistant, car salesman, dispatch boy, driver and religious tutor. When he lost his job in the 1997 Asian financial crisis, he went to Saudi Arabia, where his brother was running a business. He stayed for two years. It was only in 2007 that ' $F$ ' finally secured a position with a stable income as an ustaz in a Malaysian-run hafiz school in Kuala Lumpur. After having spent time in Bangladesh, Thailand and Saudi Arabia, 'F' seems to have decided to make Malaysia his home. He has been applying for citizenship since I999, without success.

Malaysia is not a signatory to the I95I Geneva Convention. It has, however, recognised certain population groups - all Muslim - as prima 
facie refugees. Some degree of protection from the status of illegal immigrant has thus been accorded by the Malaysian state to the Muslim Rohingya migrants. As in Bangladesh, however, this state-accorded protection has been 'ad-hoc, arbitrary and discretionary'. It has also been erratic and confusing, with different positions taken at different times by different representatives of the state, from the highest to the lowest levels. The situation worsened considerably after 1997, when then Malaysian Prime Minister Mahathir Mohamad publicly referred to Rohingyas as 'illegal immigrants' whom Malaysia was having difficulty deporting because they were not considered citizens of Burma (United States Committee for Refugees and Immigrants I999). In the subsequent government campaigns to 'rid the country' of the huge population of illegal immigrants in the country - then estimated at I.5 million - Rohingyas, who constituted a fraction of this population, were not spared.

In I998, the Kuala Lumpur office of the UNHCR was approached by Rohingyas for protection for the first time. In 2002, the UNHCR began issuing Temporary Protection Letters (TPR) valid for six months to Rohingyas who were registered with them as 'persons of concern', and in 2005, the TPR was extended to be valid for three years (Mehrom 2007). Informants rate the usefulness of the UNHCR card at 50-50. It was no guarantee, but it was still better than being undocumented. They found that some police officers did show more sympathy when shown the UNHCR card.

In the shadow of discretionary state hospitality and limited UNHCR protection, three-generational Rohingya families are now settling in Malaysia's capital city. The surest sign of a process of localisation is perhaps to be seen in the recent establishment of a surau (in 2007) and several madrassas (the first in 2005) financed by, and for, the community. The Rohingya Ulama Council had been founded by Ustaz A in 2005. Under the stewardship of the Council, which remains an entirely unofficial organisation internal to the community, several madrassas catering to Rohingya youth have been set up.

The nature of local society has facilitated the settlement process considerably. When ' $\mathrm{K}$ ' was dropped off at the Malaysian border by his 'agent', having been told by him that 'Malaysia is a good place', he knew neither friend nor relative here. Like ' $A$ ' and ' $F$ ', he drifted away from the northern border toward the southern urban centres. Arriving in Klang, he went to a local Indian mosque and, seeing that they looked Indian (and similar to Rohingyas), attempted to speak to them first in Rohingya (a dialect of Bengali), then in Burmese, Urdu and Arabic none of which cut any ice. A few days later, he overheard the Rohingya language being spoken by a group of people during Friday prayers at the mosque. He has since established himself in Klang. 
Given the existence of a local Indian Muslim as well as Malay business community, many Rohingyas have found employment with these local businesses. Thanks to their religious education (there are over 200 Rohingya ustazs in Malaysia), many have also managed to establish close ties to local Malay families, often serving as Koranic tutors. Most Rohingyas speak fluent Malay, especially the younger generation. Nonetheless, relations with the local Malay society remain ambivalent, especially with formal Islamic institutions in the country. In one mosque, foreign Muslims were separated from local Muslims during Friday prayers, having to line up at the back. JAIS, the Islamic Affairs Department, has also disapproved of Rohingya attempts to get help from non-Muslim charitable organisations in Malaysia, such as the Christian Malaysia Care.

Localisation, however, does not mean immobilisation. In fact, settlement outside of a homeland (sans nationality) and outside of the camp (sans refugee status) has meant a life of constant mobility - shuttled from border to border, either in flight or deportation, and relocation from country to country, depending on the uncontrollable vagaries of the labour and political markets. In any event, life without a nationality remains difficult. In distinguishing himself from an undocumented labour migrant, Ustaz $\mathrm{K}$, who is currently running one of the Rohingya madrassas, said:

I am not looking for money, I could look for money anywhere. It's not that I cannot live - I am looking for a life. More than that, I want a life for my children. I hope that I will not die before getting a nationality. (Interview with K, 30 November 2008)

\section{Conclusion}

The Rohingya experience suggests that refugee migration may be characterised as being open to both the possibility of settlement and resettlement (an option generally not available under guestworker labour regimes) and a life-world of hyper-mobility on the other. This mobility, in contrast to that of labour migration, is over-determined by a marked lack of directionality or low level of control over the destination and ultimate settlement. The loss of directionality stems from the vicissitude of flight from a persecuting state, aggravated by vulnerability to the actions of destination states. Notwithstanding these enormous legal barriers to the mobility of the 'unwanted' (Marrus I985), a long-term consequence of such arbitrary dispersion has been the emergence of structures of opportunities for further mobility, as social and familial ties are established 'all over the world'. Contemporary refugee diasporas tend to be 
more extensive in geographical scope for connected families than labour diasporas, and the mobility - legal and illegal - within the space thus generated is extremely high.

Refugee migration, with its inherently stateless and hence lawless i.e. outside of the transnational rights regime - character, thus throws into even greater relief the tension between the illegal and the licit, as well as the academic perils of 'seeing like a state' (Scott I998). As importantly, perhaps, it draws attention to what the modernist state (and its academics) does not and cannot see, as the space of the undocumented and the economy of the illicit remains, perforce, hidden from its administrative and hence enumerational order. In creating legibility, the state and its enumerational practices have also generated vast domains of invisibility - inaccessible not only to the eyes of the state but also to those of the academy which relies solely on the information gathered and made available by the state.

The Rohingya story also suggests that not all states see alike; in fact, with respect to the management of foreign populations, they may see very differently. The formal template of the nation-state has been adopted as the sine qua non for political existence in the modern world. Whilst taken to be paradigmatic, the modern nation-state - which frames its relations with the population within its territory (citizen and foreigner) entirely in terms of a legal orde - is more of an exception than the rule among the I92 member states of the United Nations. The new post-colonial states of the post-imperial age may have developed the formal institutions of the modern nation-state, but their substantive behaviour has often remained substantially different.

Central to the vision of the modern nation-state is the distinction between the citizen and the foreigner, ideal-typically located in territorially distinct spheres of jurisdiction. Citizens were to remain within the 'embrace' of its territorial borders, while foreigners were to remain on the outside of them (Torpey 2005). More than just a physical artefact, the territorial border was a legal construct validating the right of the state to keep its people in and others out. Territorial control became the mode of governance par excellence of the modern state. As market and society grew beyond the territorial reach of the state, however, especially since the Great Transformation (Polanyi I944) of the last century, the strict homology between people and territory has been irrevocably breached.

The modern liberal state, governed by the rule of law, continues to use legal instruments in the management of its foreign population, raising legal barriers to entry on the one hand, but providing legal space on the other for those who have been allowed to enter. A handful of Rohingyas have been allowed to enter under this legal regime. In illiberal states such as Saudi Arabia, where less legal space is accorded to 
local civil society and in particular to non-citizens, a form of autocratic management laced with notions of 'charity' appears to have been put in place. The concern of the Saudi state seems to have been less with (violated) control of territory as with the effective control of population within its territory.

We must therefore problematise the way the state sees. Different types of states 'see' differently, and in looking at the interplay between the illegal and the licit, it may be necessary to look beyond the empirical acts of migrant trespass to the question of the construction of law or legality by the state itself - and the various norms and institutions with which this is done. 'Bringing the state back in' should include a reflection at this conceptual level on the differential making of law and legality by contemporary states.

A final comment may be in order. In the age of empire, heterodoxy of population and control of population mobility were not issues. The post-imperial age of the new post-colonial states witnessed, given the paradigmatic status of the territorial nation-state, the reassertion of state anxiety regarding the territorial control of population. The system of apartheid introduced in South Africa in the I960s was the ultimate manifestation of this desire to identify populations with territory and to encapsulate homogenized populations within territory. With the great migrations of the last three decades - labour as well as refugee - this age would now appear to be coming to an end. To be able to trace its passing and the shape of the future to come, it would be necessary to see beyond the zone of European immigration and the way the state there sees.

\section{Notes}

I The use of the term 'hospitality' here references its use by Derrida (2000). However, as will be seen from the text later, the hospitality is not the absolute hospitality of Derridean provenance. 'Vernaculars' refer to shared mediums of communication such as language or religion.

2 MN was an IT student at a private college in Kuala Lumpur at the time of the interview, and is currently running a computer business in Kuala Lumpur. Both his parents were born in Arakan and trekked across Bangladesh and India into Pakistan in the early I970s, where they stayed for a couple of years before moving on to Mecca and settling there. MN was born in Mecca in I980. He spent several months in Pakistan before coming to Malaysia for his studies in I992. Whilst in Malaysia, he worked for several years for the UNHCR as a translator for Rohingya refugees. $\mathrm{MN}$, interview by authors, 8 August 2010. 


\title{
4 Smuggling Cultures in the Indonesia- Singapore Borderlands
}

\author{
Michele Ford and Lenore Lyons
}

The smuggling will never stop. As long as seawater is still seawater and as long as the sea still has water in it, smuggling will continue in the Riau Islands.

Tengku Umar, owner of an import-export business

Borders are lucrative zones of exchange and trade, much of it clandestine. Smuggling, by definition, 'depends on the presence of a border, and on what the state declares can be legally imported or exported' (Donnan \& Wilson I999: IOI), and while free trade zones and growth triangles welcome the free movement of goods and services, border regions can also become heightened areas of state control that provide an environment in which smuggling thrives. Donnan and Wilson (I999: 88) argue that acts of smuggling are a form of subversion or resistance to the existence of the border, and therefore the state. However, there is not always a conflict of interest and struggle between state authorities and smugglers (Megoran, Raballand, \& Bouyjou 2005). Synergies between the formal and informal economies ensure that illegal cross-border trade does not operate independently of systems of formal regulatory authority. Smugglers are frequently subject to a system of unofficial 'rules of law' developed through tacit agreement among trading parties, which operates in parallel to regulations imposed by the state (cf. Chang 2004; Walker I999). The existence of these parallel regulatory systems creates a situation where smuggling can constitute a form of informal power in opposition to state power while at the same time being integrated into state apparatuses. Indeed, studies of smuggling demonstrate that collusion by state authorities is almost always essential for illegal cross-border trade to occur (Chang 2004; NigerThomas 200I; Van Schendel I993). Like many other forms of illicit cross-border exchange, smuggling thus reveals the paradox of the border: even as illegal cross-border trade works to undermine the state, it also works to constitute it (Donnan \& Wilson I999: Io6).

In this chapter, we examine the unauthorised movement of goods across the border to and from Indonesia's Riau Islands from the 
perspective of the individuals who smuggle and consume them, and from the perspective of local agents of the state - individuals whose stories demonstrate the multiple meanings associated with cross-border flows across the straits and, in doing so, shed light on how state practices intersect with competing ideas about legality and licitness. ${ }^{\text {I }}$ The first part of the chapter examines this nexus between the historical formation of the border and cross-border flows of goods in the colonial and post-colonial periods. ${ }^{2}$ Here we show that although many individuals who live in the Riau Islands experience the border as a boundary and as the imposition of state rule, it also represents a resource that can be exploited. The second part of the chapter demonstrates how the often contradictory processes of bordering have shaped not only the ways that Riau Islanders imagine the border but also the state's changing definitions of, and responses to, smuggling. In particular, our study of the Riau Islands reveals that local state involvement in 'illegal' acts (such as corruption that supports smuggling) can be seen as a legitimate response to local needs and the perceived failures of the national government and legal system - a fact that points to the need to explore local ecologies of licitness (and illegality) not just in terms of community perceptions but also in terms of different levels of the state.

\section{Local Responses to Evolving Practices of Bordering}

Smuggling has been an integral part of life in the Riau Islands since the British and Dutch began to carve out spaces of economic interest in the Straits of Malacca. Since the late I80os, cross-border flows of goods (and people) have been shaped by efforts to create borders through the establishment of colonial territories and then new sovereign states. The Straits of Malacca, which divide Singapore and Malaysia from Indonesia, have long been the site of a flourishing economy of smuggling (Trocki I979, I990). In fact, the history of the border is a history of attempts to control the flow of people and goods across the straits. The Anglo-Dutch Treaty of I824 gave the Malay Peninsula and the island of Singapore at its tip to the British, and Sumatra and the Riau Islands to the south of the Straits of Singapore to the Dutch. At that time, the Dutch were much more interested in establishing and policing the border between Singapore and the Riau Islands than the English (Tagliacozzo 2007) - an interest that reflected their desire to control the movement of contraband across the Anglo/Dutch frontier and to regulate the flow of taxes into the colonial coffers. Attempts to do so were only partially successful, and a booming cross-border economy (much of it deemed illegal by the Dutch) developed that led to the 


\section{Map 4.1 Map of Riau Islands}

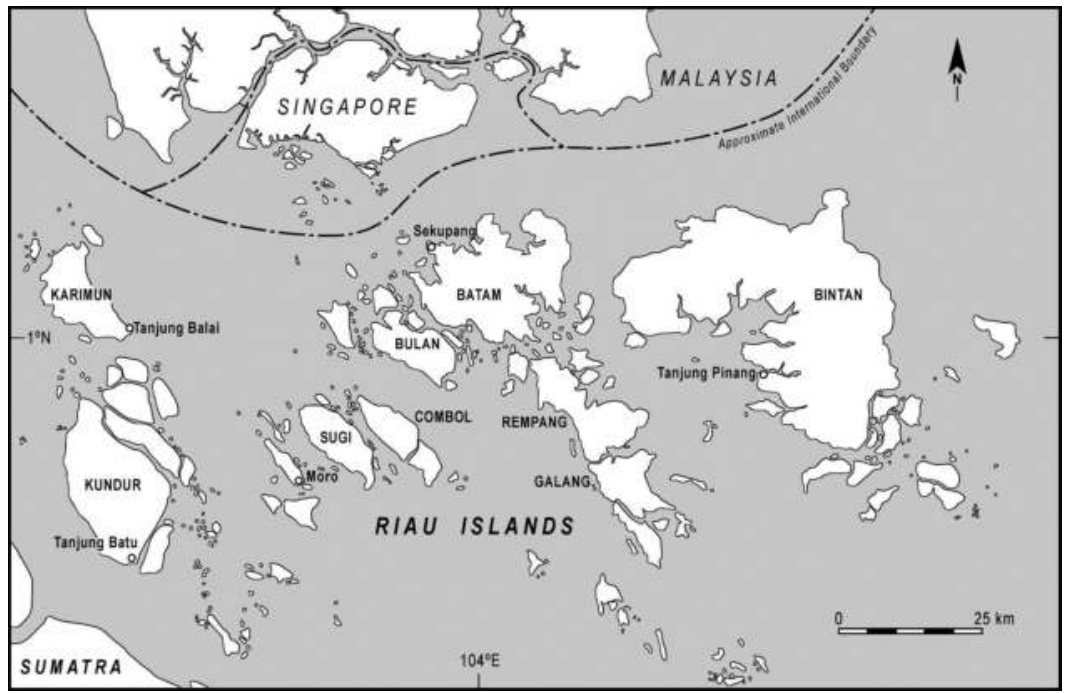

Riau Islands becoming far more closely integrated into the Straits economy than they did with the rest of Dutch East Indies. ${ }^{3}$

During the Second World War, the boundary between the Dutch and British spheres was even further weakened with the creation of the Japanese 'co-prosperity sphere'. Administratively, Malaya and Sumatra were ruled by the $25^{\text {th }}$ Army, which encouraged civilian maritime trade, and the Riau islands fell under the administration of Syonan (Singapore). The Japanese occupiers played a central role in facilitating smuggling across the Straits through the setting up of kumiai (co-operatives) engaged in cross-Straits trade. Shortages in food and other products provided opportunities for a new form of smuggling to emerge danbang trade - a type of business conducted by self-employed itinerant traders (Twang I998: I3). The brief period of Allied Occupation that followed was heralded a 'golden age of smuggling' (Twang I998: 2I4), but this changed when the Dutch colonial authorities returned. Because smuggling was vital to sustaining the economy in Republican areas, the Dutch were determined to control the flow of goods across the Straits (Yong 2003). However, danbang trade continued and other firms involved in anti-Dutch smuggling mushroomed, leading to the founding of import-export associations in Singapore and Penang that were directly involved in cross-border barter trade (Twang I998: 13). Using a combination of naval blockades and increased regulation, including the introduction of a new banking system that controlled foreign exchange, the Dutch succeeded in controlling the trade by the end of r947. The 
more determined smugglers, however, were harder to eliminate, and the smuggling trade continued, albeit on a much smaller scale and no longer openly backed by the British. As a consequence, it became more covert (Twang 1998: 240).

Cross-border trade remained the mainstay of the islands' economy in the immediate post-colonial period due to strong demand in Singapore for items from the islands, including coconut, copra, rubber and fish. ${ }^{4}$ Islanders in turn relied on a range of products 'imported' from Singapore, including fresh vegetables, rice and clothing. This was the 'Era of the Dollar' (zaman dollar) when islanders frequently travelled to Singapore to purchase goods and services. Our informants recounted that the islands were 'flooded by Singaporean goods' and even local officials were paid in Singapore dollars or 'KS' (Kepulauan Riau dollars). Not only were dollars used to buy and sell goods, but price differences between Singapore and the Riau Islands were quite stable: local regulations put in place in the I950s required ships bringing in goods from Singapore to present a purchase receipt to Indonesian trade officials on arrival into port. The official would then determine a selling price that took into account transportation costs.

In addition to this regulated trade, there was also a considerable amount of what the new Indonesian government regarded as smuggling. Some of this trade was highly organised and visible. Awang, a Malay teacher from Tanjung Balai Karimun, recalls that during the I950s he was one of the richest men in his community because of the high prices his copra attracted. He would ship coconuts from Sumatra to the islands and manufacture copra, which was then sent by ship to Singapore. Other cross-border trade activities were conducted on a much smaller scale. Sugiyanto, a Javanese day labourer who has lived in Tanjung Pinang since I959, recalled that going to Singapore was 'just like going to the market', as islanders would regularly row over to Singapore to sell a few kilograms of chillies or rubber. He recollects that 'there were no obstacles and no-one bothered us'. Hamzah, a 62-yearold Bugis fisher living in the north of the island of Bintan, recalls that he and his brother-in-law regularly traded dried coconut and fish in Singapore and bought rice, sugar and clothes in return. None of these islanders regarded their business as a form of 'illegal' activity but rather a form of 'unregulated' cross-border trade.

All this changed with the period of military brinkmanship and associated low-level skirmishes between Indonesia and the Malay Federation in 1963 , known as Confrontation. ${ }^{5}$ Although Confrontation did not turn the islands into a war zone, its impact on local communities was nevertheless dramatic and abrupt, as the movement of goods and people across the border became more restricted (Ng I976). As a result, Riau Islanders were cut off from 'their paddies and fields' (sawah 
ladang) in Singapore and Malaysia. There was little agricultural production in the islands and they relied on the importation of fresh vegetables and staples such as rice, so when their traditional trade routes were cut, supply dried up and food became extremely expensive, as they had to rely on shipments of foodstuffs from Java. The goods were first sent to Tanjung Pinang and from there they were transported by boat to the outer islands. As Hamzah remembers it:

During Confrontation it became really hard to get to and from the islands, so it was very difficult to keep our relationships with Singapore going. As a result, we really suffered economically. It was very difficult to get even basic necessities. Sometimes we'd have the money to buy food, and there'd simply be none that we could buy.

According to Rizki, a 65-year-old retired civil servant, islanders 'did it tough' during this period because all their official connections with Singapore were cut; although it became more dangerous to do so, 'the only thing people could do was to become involved in smuggling'. Confrontation affected different ethnic groups in different ways. While Malays like Rizki and Hamzah suffered, Bataks and Chinese itinerant traders were able to take advantage of their connections in Medan and Jakarta to continue trading (Ng I976). During this period, older generations of Chinese businessmen in Tanjung Pinang also suffered, but a new group of businessmen emerged and, using their connections with Indonesian officials, were able to establish lucrative smuggling businesses (Ng 1976: 51).

Remote communities suffered the most in the aftermath of Confrontation because of the time and distance it took to deliver food and other commodities to the islands. Raja Ali, a Malay who lived in Natuna before moving to work in Tanjung Balai Karimun in 1964, recounts that shipments from Tanjung Pinang took several days to reach their destination. The quality of rice and sugar shipped from Java was 'terrible'. However, he considered himself relatively lucky because as a school teacher, his family received io kilograms of rice per person. Other people received only 200 grams. This did not mean that Raja Ali's family was spared from hunger. They shared their rice with a large number of relatives and mixed it with cassava to make it last longer. However, his relatives were worse off because they had almost no rice at all, and were forced to eat cassava and sago and considered themselves lucky if they could mix in a spoonful of rice.

The end of Confrontation did not signal the end of hardship. The rupiah finally replaced the Singapore dollar, and mainland Riau began to dominate the trade of primary products. Food and other goods 
continued to be shipped from Jakarta. Government wages were lower as a result of the change in currency, and many public servants turned to smuggling to supplement their income. Then, as Zamri, a school principal in Tanjung Balai Karimun, recalls:

In I965, we faced a new problem with the Communist rebellion. Suddenly everything had to come from Jakarta and our wages just weren't enough. Lots of teachers were involved in smuggling. In those days, all the government officials had two functions (dwifungsi). On weekdays they sat in their offices, but on Saturday they'd catch a boat straight to Singapore or Malaysia and buy stuff to smuggle back. That's what my family did.

While small-scale, petty smuggling became almost routine during this period, large-scale shipments across the border became more difficult to secure. Awang continued to sell his copra in Singapore, smuggling about five tons a week, but the situation became more and more difficult.

It was not until I968, when relations between Singapore and Indonesia were normalised, that things began to improve again as a result of restored cross-border mobility. Ethnic Chinese and Malays resumed their movements back and forth across the Straits, although now the process of border crossing had become more formal with the imposition of immigration controls. Older residents recalled that islanders entering Singapore did not carry passports but were required to have their photograph taken and were given a stamp from the Singapore immigration post that would allow them to stay in Singapore for 48 hours. Although by this time the rupiah had long been the official currency of the islands, a large proportion of economic transactions were again being conducted in dollars. A flourishing culture of smuggling ensured that islanders evaded import duties and continued to have access to cheap products from Singapore.

In the I970s and I980s, most traders operated as they had before the border was regulated. During this period, Raja Ali recalled, 'All the armed forces were here, but not because there was a war. They were here to trade'. In the I970s, a 'floating market' ship from Singapore was moored in the Malacca Straits and people from Karimun would take their goods to barter at the market. Raja Ali claimed that the direct involvement of the Indonesian armed forces in smuggling activities like the floating market helped to improve the quality of life in the islands from i968. Awang also commented on the armed forces' active engagement in smuggling during the Suharto years: 
When Suharto was in power, the generals owned the ships. They flew a yellow flag so if they were caught by customs, the customs officers would know who owned them. It was a good arrangement though, because it meant that it was possible for people in Balai to do business in Singapore and Malaysia, and that benefited everyone.

The use of the Singapore dollar for everyday trading and the continued culture of smuggling meant that - in contrast to most Indonesian communities at that time - many residents of Tanjung Pinang on the island of Bintan had access to television sets (watching Singapore channels) and a range of electronic goods (Ford \& Lyons 2006).

A decade later, Dasril, an ex-smuggler from Karimun who now has a vegetable stall in the local market, travelled to Singapore regularly:

My brother and I would go to Pasir Panjang to sell rambutan. We'd use the profits to buy second-hand goods to bring back to Karimun, like foam mattresses, armchairs and electric appliances. It wasn't difficult in Suharto's time. We used to make a good profit out of the goods we brought from Singapore. You could make a really good living from smuggling.

Some locals became involved in grand clandestine schemes. One former teacher from Tanjung Balai Karimun recounts his induction into the smuggling culture in the mid-I970s after he was approached by the son of an Indonesian general. He couriered thousands of watches from Singapore to Jakarta for almost a year, earning five dollars per piece, stopping only when he was detained by officers of the national intelligence agency and recruited as a spy to track illegal money and drugs coming in from Singapore. However, most smuggling was conducted on a much more modest scale, targeting local consumption. According to Kifli, a middle-class public servant from Tanjung Pinang, in the midI980s, 'everything in Pinang was from Singapore'. In recollecting the culture of smuggling in the I980s, Raja Khaerudin, an ex-teacher and former member of the local parliament and now a high-ranking official within the local branch of the Golkar Party, claims that it was considered 'just to be a form of trade that had grown out of local practices'. Not only was smuggling considered to be a lucrative form of trade, it was also considered to be normal. While some foodstuffs and luxury items were cheaper than their Indonesian counterparts, their most desirable characteristics were the convenience and speed of delivery and the inherent 'quality' characterised by superior performance, durability or taste. Faced with the choice between Indonesian products and 
smuggled Singaporean or Malaysian goods, many islanders chose the latter.

Things had changed considerably by the late i980s, as the border began to play a much stronger symbolic role in marking out the differences between a developing Singapore and a backward Indonesia, even though physical movement across the border by traders and smugglers continued as it had for decades. At the same time, improved transport routes between Sumatra and Java made smuggling less attractive for some traders. For Zaki, a Chinese businessman originally from Tembilahan, the improved flow of goods from Pekanbaru and Jakarta meant that he began to buy mostly Indonesian goods, although if he wanted high-tech products he continued to source them from Singapore. However, shortages continued to be inevitable because of delays in delivery from Java, and when goods arrived they were frequently damaged because of the distances travelled. By contrast, goods coming 'from across the water' (dari seberang) arrived in perfect condition in a matter of hours.

The establishment of the Indonesia-Malaysia-Singapore Growth Triangle (IMS-GT) in I990 brought a new twist in the relationship between the state and the community with regard to cross-border trade. The IMS-GT aimed to reduce Singapore's reliance on foreign investment and overseas markets and make the economy more resilient in times of recession (Yeung I998). The underpinning philosophy of the IMS-GT was economic complementarity in which Singaporean capital would be combined with Indonesian and Malaysian labour and land to facilitate cross-border regional growth (Sparke, Sidaway, Bunnell \& Grundy-Warr 2004). As a direct result of the growth triangle initiative, industrial manufacturing zones and tourism projects were established on Batam and Bintan. ${ }^{6}$ Despite the rapid industrialisation that followed, the promise of economic growth that underpinned the IMS-GT initiative was not entirely fulfilled.

Yet despite the limitations of the IMS-GT, our respondents perceived the early I990s as another time of prosperity. For Jali, a Bugis man born in Tanjung Pinang, the early I990s was a period of opportunity. He would buy damaged second-hand electronics in Singapore and rebuild them for sale in Tanjung Pinang. He describes his activity as 'a form of smuggling. You could say we were "playing behind the scenes" (main belakang), on the black market'. He would charter a small boat in Tanjung Pinang and load it with mangrove wood. The wood was dropped at an unofficial port in the mouth of a small stream near Jurong, where he would buy second-hand goods to smuggle back. The entire transaction occurred at the illegal port and although he took money with him in case he needed to pay off an official, it was rarely required. According to Jali, 'The Singaporean customs guys didn't care 
what we brought in, but the Indonesian customs boats patrol the straits. The most that ever happened though is that they'd ask for one of the TVs'.

Smuggled goods became much less attractive in the wake of the Asian Financial Crisis of 1997-98, when weak exchange rates made it more difficult for smugglers to make a profit. Singaporean and Malaysian products were still available but were now much more expensive than products brought from Java and elsewhere in Indonesia. However, entrepreneurial traders were able to take advantage of the growing size of the middle classes in the islands. Topan, a Batak man living in Tanjung Pinang, started smuggling clothing and electronics from Singapore in 2002 because of the strong demand for international brands. He trades in second-hand goods, which he claims are discarded by rich Singaporeans who constantly seek to have the latest products. In spite of the unfavourable exchange rates, Topan claims that he is able to buy goods at a reasonable price and make much more money selling them in Tanjung Pinang than if he sold brand-new, Indonesian-made products. As Domartin, a former journalist and party official from the Karimun branch of the Peace and Welfare Party (Partai Damai Sejahtera), says, 'It's not that middle and lower class people in the islands really want second-hand goods, but they're a great bargain. Even the bureaucrats will buy them. They're often $90 \%$ as good as new'.

The evolving political context in the post-Reformasi period had an even more dramatic impact on cross-border trade than changes in the exchange rate over the same decade. As Hendri, a hotel worker employed in the Bintan Resort Zone, observed:

Things have gotten really tough since SBY [Susilo Bambang Yudhoyono] became president in 2004. In the past, there'd be a bit of a shake-up when a new official was appointed, but it only ever lasted a month or two. A new police chief would be appointed and things would tighten up for a month and then go back to normal. This is the first time it's been like this. Lots of people are really unhappy about it.

One immediate effect of the new political regime has been a crackdown on smuggling. According to Leo, a middle-class Malay from the town of Kijang on Bintan, once Yudhoyono became President, 'the only people brave enough to bring in rice without paying tax were Chinese businessmen'.

In our interviews with active and former smugglers, many claimed that the central government's policy on smuggling had seriously affected them. Tengku Umar, a Malay from Tanjung Balai Karimun who runs an import-export business, asserted that the customs duties 
imposed under the new regulations are designed to make particular items more expensive in the islands. While some items continue to be easy to smuggle, others have become more difficult. For example, the timber and furniture industry has experienced a significant reduction in the availability of building materials. According to Nanang, a Javanese from Tanjung Pinang, for example, the strict new laws meant it became difficult to buy wood: 'Lots of shops just don't have any anymore. And when you ask them why they're out of stock they say it's difficult to get it in. What they mean is that they can't get it in illegally'. But smuggling continued despite attempts by the central government to stop illegal cross-border trade. For example, Lini, a Chinese furniture shop owner in Tanjung Pinang still mostly sells furniture from Malaysia, travelling there every week or two to buy stock.

\section{Local Ecologies of Licitness}

Just as illegal logging generates direct or indirect employment for many people in the local community in Aceh (McCarthy 2002: 880), smuggling - along with other illegal or legally marginal industries like gambling and commercial sex - plays a vital role in the local economy of the Riau Islands. ${ }^{7}$ As our discussion suggests, communities like those located on Indonesia's borders with Singapore and Malaysia regard smuggling as a natural part of life in the islands and consider their involvement in it, or their purchase of smuggled goods, as legitimate acts that reflect the special character of border life. Abraham and Van Schendel (2005: I7) use the concept of licitness to take into account this gap between the state's understanding of illegal activity and the understanding deployed by individuals within borderland communities, calling for the need to identify the origins of regulatory authority and to distinguish between political authority (whether something is legal or illegal) and social authority (whether it is licit or illicit). In their study of smuggling between the Gambia and Senegal, Golub and Mbaye (2009: 597) argue that smuggling is a 'natural outcome' of long trading traditions in Africa which, along with pervasive poverty, creates a drive to obtain goods at the lowest possible cost and to earn a living. NigerThomas (200I) also invokes the concept of licitness (although she does not use this term) in her discussion of smuggling along the border of Cameroon and Nigeria, arguing that women traders "perceived their activities as just another business enterprise and saw themselves in a favourable light, as entrepreneurs taking risks' (Niger-Thomas 200I: 46).

While different state responses to cross-border trade have resulted in some of these goods being deemed at one time by at least one state to 
be 'illegal', many Riau Islanders also regard these unauthorised flows of products to be a form of licit commerce between traditional trading partners. As in Nunukan (see Bakker \& Crain in this volume), they are both an important source of livelihood and an integral part of the dense web of relationships that bind them to friends and kin on either side of the international border. Small-scale smuggling by individuals continues to represent an important means of making a living or earning a little extra income, and the Chinese and Malays who visit family members in Singapore and Malaysia routinely purchase consumer goods like clothes and jewellery, which they smuggle back into the islands for sale. Despite the crackdown, there also remains a 'systemic synergy' (Passas cited in Antonopoulos 2008: 275) between businesses in the formal sector (such as supermarkets, furniture shops, electronics retailers, hardware shops and clothing stores) and those that engage in smuggling.

We propose that smuggling, along with other illegal and semi-legal industries, in fact sits at the core of a kind of 'local ecology' in which some forms of illegal activity associated with the borderlands are clearly licit. This in part reflects the fact that at different times, the same crossborder flows have been designated as 'trade' or 'smuggling', and the goods themselves as 'legal commodities' or 'contraband'. As Aseong, a former customs officer and fish exporter, observes:

It usen't to be called smuggling. That term didn't exist then. But now it's there in a law. If we bring goods in without the proper paperwork, that's called smuggling. It just didn't exist before. In fruit season, everyone used to take fruit from here in fruit season - mangoes or rambutan or pineapples or coconuts - and trade it in Malaysia or Singapore for other kinds of food. People would see their family at the same time. The law has made it more difficult but it hasn't destroyed that trading relationship. It's a necessary part of life.

While locals recognise the authority of the central government to issue laws on smuggling and to impose taxes on cross-border trade, they insist that such laws unfairly disadvantage islander communities. In the Riau Islands, we were repeatedly told by people from all kinds of backgrounds and walks of life that without smuggling, the islands simply could not survive. Many Riau Islanders argue that they should have special permission from the central government to import staples from Singapore and Malaysia. As Gusril, the computer trader, commented:

To my mind - to the mind of an ordinary person - it doesn't make sense to ban imports of things like sugar and rice because we need those things and it's difficult to get them from Java. 
They have to go to Batam first and then they sit around in a warehouse for months before they make it to Karimun. If you want staples from Singapore, you just need to make a phone call and they arrive the next day.

According to Amunidin, who works in a large private firm in Tanjung Balai Karimun, 'We'd be much better off if they let us trade freely'. As Hendri, a second-hand clothes seller in Tanjung Pinang, argues, 'We're on the border here. We should be given a special exemption'. Importantly, even in the absence of such an exemption, Gusril doesn't regard his 'importation' of computers from Singapore as a form of smuggling. He and other local business owners who sell illegally imported goods do not see themselves as smugglers. Rather, they see themselves as entrepreneurs seeking to maximise their profits through clever strategies to import cheaper, better-quality products from Singapore and Malaysia.

There is considerable public support in the islands for this view. These claims for the licitness of smuggling rest on a range of intersecting discourses about the proximity of the Riau Islands to Singapore and Malaysia, and the price and quality of goods from other parts of Indonesia. In our interviews with members of the community who purchased smuggled goods, many claimed that the local economy would suffer enormously if smuggling stopped because Indonesian products are much more expensive. The 'moral status' (Tremblay, Cusson \& Morselli I998) of smuggled foodstuffs and consumer goods is thus very high. ${ }^{8}$ Not only are smuggled goods often still cheaper than similar items produced in Java, they are also considered to be of a better quality. Riau Islanders acknowledge that the quality of products from Java has improved dramatically since the I970s but still consider the vast majority of them to be inferior. As Awang observed:

Sometimes domestic products look the same, but after a week or so they start disintegrating. So even though imported products are more expensive now, we still try to buy them. We only buy domestic products if they're the only ones on offer.

Shopkeepers actively promote the qualities of Singaporean products, often displaying foreign products next to Indonesian products and encouraging their salespeople to demonstrate the differences in quality. This technique is commonly employed in shops selling foreign items that are considerably more expensive than local products. As the Javanese day labourer Sugiyanto says, 'Even if the imported stuff is dearer, I still buy it. It might cost more, but at least I'm satisfied'. 
There are, however, limits inherent in the moral discourse of licitness. For example, Gusril asserts that unregulated cross-border trade becomes smuggling when large-scale operators try to sell their products outside of the islands. ${ }^{9}$

The problem with the fancy businessmen is that if we ordered ten they'd bring in I,०00 and smuggle the 990 others out. I'm not sure how they were doing it. So that's when all the fuss blew up and importation of electronic goods was banned. And we're the ones who suffer. We just want to trade to make a living for our families, we're not looking to get rich.

Many other importers similarly blamed this kind of behaviour on 'outsiders' who break the unwritten rules of cross-border trade in the islands and try to make a profit by selling on goods to other parts of Indonesia, ruining things for local residents.

The community also invokes its local ecology of licitness when assessing state engagement in illegal cross-border trade, rejecting unreasonable levels of corruption such as that perceived to be characteristic of the new layers of local government, but at the same time recognising the role that local agents of the state play in ensuring the welfare of borderlanders. In the literature, the actions of a central government are often contrasted with those of its officials, many of whom benefit from smuggling through the taking of bribes. As Niger-Thomas (200I: 46) has observed in another context, 'official corruption is an integral part of all smuggling operations, thus grafting informal activities onto the formal sector'. However, central government officials are not always in opposition to smuggling, as many of these accounts imply. As Sugiyanto observed, 'Groups of officials who came from Jakarta to stop smuggling don't apprehend any of the smugglers. They get given smuggled goods as gifts!' Importantly, also, local state authorities are not only involved in supporting smuggling through corrupt practices; government agencies are also frequent customers of smugglers, both individually and as institutions. For example, a senior officer in the Police Intelligence and Security Unit interviewed in 2010 acknowledged that his wife purchases contraband Milo and sugar from a Chineseowned shop, arguing that there was no reason why they or other local people should purchase expensive, inferior Indonesian products. ${ }^{10}$ Meanwhile, some of the smugglers of high-tech goods that we interviewed reported that government agencies were among their best customers.

This systematic engagement of agents of the state in the economy of smuggling is reflected in the extent to which the industry is regularised. As Zainul, a civil engineer and contractor working in Tanjung Balai 
Karimun, observed, 'When goods are smuggled, the person selling them only has to pay 'administration costs'. They don't have to pay tax, so they can keep the prices down. The costs referred to by Zainul are usually paid by the boat owners or those who hire the boats. These costs are then passed on to local entrepreneurs who engage the boat owners to 'import' their goods. Gusril sums up the sentiments of the local business community:

I don't think too much about whether the goods I buy in Singapore come through official channels. All I need to know is that the goods I buy can be shipped to Karimun. What happens on the way here doesn't concern me. It's up to the people who own the boat to deal with that. All I do is pay the bill and get the goods. It's no big deal.

As with the scale of smuggling operations, however, there are limits to this routine and institutionalised support for what could be called 'mundane' smuggling. For example, Anai Oi, a Chinese vegetable trader from Tanjung Balai Karimun, openly brings in vegetables from Malaysia. He does not pay taxes on the import of the vegetables but instead pays an informal fee to the people who own the boat. He claims that this arrangement has been successful because local officials 'don't care too much about veggies. It'd be different if I was trying to bring in meat. Then I really would have to have the right paperwork to get my stock in'.

Equally, the community imposes moral boundaries on state interference in cross-border trade in ways that are recognisable in other contexts. For example, Prokkola (2008: 67I) argues that in the context of smuggling between Sweden and Finland, 'the border does not separate people but marks a confrontation between state governance and the local way of life'. Similarly, in her account of the Benin-Nigeria border, Flynn (I997: 318) claims that for the Shabe:

[B]orderland marginality is made ever clearer by the hovering, hoarding, commanding presence of the state, the perceived purpose of which is not to help border residents but to hinder their advancement by stifling what was once their promising path to development - lucrative transborder trade.

Regional autonomy and the creation of a new province (Propinsi Kepulauan Riau, Kepri) has resulted in a proliferation of government agencies and added a new dimension to state corruption in the islands. Local communities have begun to complain about rent-seeking by different arms of government, particularly in Karimun, where new layers 
of administration were added when it became a Regency in 2000 , creating a range of new positions with the result that smugglers who used to have to pay one set of bribes now have to pay two. ${ }^{\text {II }}$ The increased presence of the police and navy has also dramatically affected the flow of goods across the border. For example, Ahui, a former customs officer in Tanjung Balai Karimun, complained to us that suddenly the navy and the police began to interfere with the work of customs officials and began to extract additional 'fines' from smugglers. Not only did this reduce the profits of smugglers, it also undermined the 'side incomes' (penghasilan sampingan) earned by customs officials.

Ahui's views should not be seen simply as a response to increasing competition for pay-offs. He expresses the sentiments of many local officials who argue that these new agents of the central government do not appreciate the importance of smuggling to the local economy. Similarly, a common reason given for rejecting the post-2004 crackdown on smuggling to and from the islands is the view that the central government, which is believed to be synonymous with Javanese interests, is working to protect Javanese industries. According to Amunidin, a Malay who works for a large private business in Karimun, the government does not let Riau Islanders import products from Singapore 'because the Javanese produce these things and have trouble selling them here if we're not forced to buy them'. In response to pressure from businesspeople, local authorities have lobbied the central government to introduce special laws for the islands that would allow them to import foodstuffs from Singapore and Malaysia. Mukhlis, a former head of what was then the sub-district of Karimun, also argued that changes to the regulations governing the import of food stocks from Singapore had an enormous impact on people living in the district, asserting that, 'Sure, there can't be room for large-scale trade, but restrictions on the importation of basic needs like food and clothing has a terrible effect on local people'. When still in power, Mukhlis approached the Minister for Trade to allow basic necessities such as rice and sugar into the islands without taxes, but the Minister refused on the grounds that it was not possible under the existing laws. ${ }^{\text {I2 }}$

Local politicians and officials like Mukhlis both criticise the central government's policy and at least in part condone local smuggling activities, which they too see as a necessary part of life. This view is summed up in the following observation from Kartini, a former member of parliament from the Indonesian Democratic Party of Struggle (Partai Demokrasi Indonesia-Perjuangan, PDI-P):

People at the centre think that those of us who live in the borderlands should go to Jakarta to buy and sell things. But if you think about a small island on the border of another country, it makes 
sense to sell its products there. They shouldn't be taxed. Take our little islands close to Singapore, for example. The people who lived there just needed a sampan to sell their goods in Singapore. Why should they be taxed? There's no way they can get to Jakarta! They shouldn't be penalised for smuggling even if it does hurt the national economy. Rice, oil, that sort of stuff, all comes illegally from Singapore. But what made people around here get involved in smuggling is the fact that the national law doesn't take account of local conditions. The regulations just don't make sense. I understand that Indonesian law applies to the whole of Indonesia. But it's not fair for the people of Kepri ... People in Kepri are penalised because we live on the border of a country that doesn't have a border with anywhere else in Indonesia. So who do you say is creating corruption in Kepri? It's the central government!

These ongoing conflicts between legal processes imposed by the central government, official corruption and local discourses of licitness may in part be resolved by the fact that decentralisation has allowed locallybased state agents to pass regulations that permit locally licit (socially accepted) but formally illegal practices, sometimes even in contravention of national laws. ${ }^{\mathrm{I} 3}$ Where resolution in this way is not possible or perhaps desirable, local ecologies of licitness may continue to provide moral sanction for illegal state activity. What we are talking about, therefore, is not a gap between the state's understanding of criminal activity and individuals' understanding of criminal activity, as proposed by Abraham and Van Schendel (2005: I7), but rather a situation in which the agents of local state structures act in ways that defy centrally defined notions of legality but conform to the local community's understandings of licitness.

\section{Conclusion}

Smuggling relies on a two-way flow of goods, and therefore the importation of unauthorised products goes hand-in-hand with the sale of produce from the Riau Islands in the markets of Singapore and Malaysia. Farmers, fishers and small-scale manufacturers depend on the regular passage of boats across the straits to reach their markets. For the boat owners and transport companies involved in shipping goods across the straits, smuggling is a state-imposed term to describe their involvement in the reciprocal flow of goods between trading partners. Although they pay the special 'shipping charges' involved in bringing goods into the islands, the businesses that use their transportation services are 
generally not interested in knowing about the techniques used to evade customs officials, the police or the military. The 'naturalness' of smuggling is attributed - by smugglers, their customers and by those who purchase smuggled goods - to the unique characteristics of island life. These special features include the geographical proximity of the littoral states to the border, pre-existing kinship and trade ties, and economic complementarity that arises between the trading partners. Smuggling is thus an integral part of a reciprocal trade process that has evolved over centuries and is so embedded in the local economy of the Riau Islands that it is almost meaningless to try and differentiate between the for$\mathrm{mal} /$ legal and informal/illegal sectors.

As we have argued here, the experience of the Riau Islands demonstrates the importance of exploring how local ecologies of licitness and illegality are shaped by intersecting perceptions of community members and local state officials of cross-border trade. In Kepri, the licitness of legitimate but illegal cross-border trade and local government corruption is juxtaposed against the repressive actions of the central government as it attempts to control the border. As our interviews with current and former local government officials and politicians revealed, many of these actors view local state involvement in corruption that supports smuggling to be a legitimate response to the perceived failures of the national government and its lack of appreciation for the special character of border life. In other words, distinctions between the legal/licit and the illegal/illicit are complicated by local state practices deemed by the community to be a legitimate response to bad laws. According to officials and ordinary citizens alike, then, a certain level of local government corruption is a legitimate response to the perceived failures of the central government, which is located far away in Java and thus unresponsive to the needs of Riau Islanders.

\section{Notes}

I The account that follows is based on interviews conducted between 2004 and 2010 as part of a larger study of citizenship and identity among borderland communities funded by an Australian Research Council (ARC) Discovery Project grant In the Shadow of Singapore: The Limits of Transnationalism in Insular Riau (DPo557368). We thank Nick Long for his insightful comments on an earlier version of this chapter and Wayne Palmer for his assistance with interviews conducted in 20 Io.

2 Donnan and Wilson (I999: IOI) have noted that much of the scholarship on smuggling gives attention to the smuggling of goods into a country rather than out of it. Although Indonesian authorities have given much more attention to the flows of goods into Indonesia than they do to flows out of the islands, one exception to this is the Singapore government's involvement in the 'illegal' (from the Indonesian perspective) importation of sand. By contrast, the Singaporean government has taken little 
interest in the flows of goods into and out of its jurisdiction, with the main exceptions of people smuggling, contraband cigarettes and alcohol and illegal drugs.

3 The Dutch also imposed regulations on trade between the Riau Islands and Mainland Sumatra.

4 The islands were incorporated into the Republic of Indonesia after the Dutch finally granted independence in 1949 .

5 For an account of the background to Confrontation, see Hindley (1964) and Mackie (I974).

6 For details of major IMS-GT projects, see Peachey et al. (1998) and Pereira (2004).

7 For an account of the sex industry, see Ford \& Lyons (2008).

8 Wiltshire et al. (200I: 206) found that smokers in the UK expressed a similar view about contraband cigarettes. They expressed a positive attitude towards smuggling in view of the high taxes imposed on legal cigarettes, as summed up in the following quote: 'to me, they're doing you a favour ... They're doing people a service'.

9 In her study of the Swedish-Finnish border, Prokkola (2008) makes a similar distinction between the ways border communities viewed 'traditional' and 'modern' forms of smuggling. Traditional smuggling was not regarded as a crime but simply as an activity carried out by 'local heroes' designed to benefit the local community. In contrast, modern-day smuggling (e.g. of drugs) is seen to be a form of criminal activity.

Io According to the officer, there is no tolerance for smuggled luxury goods like televisions, which robs the Indonesian government of substantial amounts of tax revenue, but crackdowns on daily commodities only occur when prompted by directives from Jakarta.

II Kabupaten Karimun was formed with the passing of Law No.13/2000 on the Alteration of Law No.53/1999 regarding the Formation of Kabupaten Pelalawan, Kabupaten Rokan Hulu, Kabupaten Rokan Hilir, Kabupaten Siak, Kabupaten Karimun, Kabupaten Natuna, Kapubaten Kuantan Singingi and the City of Batam.

I2 This is not to suggest that the view that the islands should receive special dispensation is not shared by all local officials. Leo, an economic adviser to the Bupati, claims that goods from Jakarta are more expensive than foreign products because the local government hasn't 'cracked down hard enough' on smugglers. In his view, local authorities should close the border so that smugglers are unable to sell foreign goods more cheaply than locally-made products.

I3 Ford and Tjandra (2007) observed similar struggles for control in the labour sphere in Surabaya and Batam. According to Agung Pambudhi, the Director of the Committee for Regional Autonomy Implementation Monitoring (KPPOD, Komite Pemantauan Pelaksanaan Otonomi Daerah), a large proportion of the local regulations dealing with labour passed in 2007 were later annulled because they contravened national labour law (interview by Michele Ford, I6 May 2007). 


\title{
5 Trade, Transnationalism and Ethnic Infighting
}

\author{
Borders of Authority in Northeast Borneo
}

\author{
Laurens Bakker and Jay Crain
}

Nunukan, the northernmost district of the Indonesian province of Kalimantan, is literally on the outskirts of the Indonesian state. Its long and narrow territory stretches from the Sulawesi Strait in the east to the rugged mountainous interior of the highland plateaus of northern Borneo's interior in the west. The district shares a very long international border with the Malaysian states of Sabah (to the north) and Sarawak (to the west). Nunukan has a long history of trading with close and more remote partners, a market that was rather hampered by the incorporation of the area first into the Dutch East Indies and then into the Republic of Indonesia, and Nunukan's subjection to the laws of both regimes. For most of the twentieth century, Nunukan's official status was hence no more than that of a remote, sparsely populated and underdeveloped territory incorporated into the far larger district of Bulungan. All this changed after the fall of Suharto as president of Indonesia and the ensuing reform of the nation's administrative organisation.

Our approach to realms of authority in Nunukan is concerned with three essential points of departure. Our first issue is the source of authority. Official law, as a major and obvious source, gains meaning from what it authorises as much as from what it forbids. As such, the law and its negation are opposites that define and construct one another. The existence of the one gives shape to the other, making the possibility of transgression a property inherent to all law (Anders \& Nuijten 2007: I2). The existence of state law thus gives rise to an interest in its counterparts (Heyman \& Smart I999: I), which may be seen as more just, reasonable or simply more profitable. Second, authority is therefore not limited to official law. As Moore (1973) argued in introducing the concept of the 'semi-autonomous social field', multiple sources of authority may exist and co-exist in various spheres of influence. Official law is among those, but its authority may well be challenged by - or even overlap with - other sources of authority. Moore thus refers to social space as a metaphor for the realm in which an authority has 
validity, but he does not equate that realm to actual, physical territory. Our third premise is therefore that, as a field of authority need not be limited to physical territory, neither do its borders. The validity of authority may be inscribed into the status of persons or objects that can be moved and that are therefore unrelated to a specific territory (Von Benda-Beckmann, Von Benda-Beckmann \& Griffiths 2005).

Authority, then, is a dynamic and fluid property that can move, expand and retract. Popular acceptance of a state monopoly on authority, as official law presupposes, is no foregone conclusion. Where multiple authorities coexist, a smooth functioning of affairs is likely to require an inter-authority cooperation that exceeds the normativity of individual parts - state as well as non-state - thus giving rise to state authority straddling a legal-illegal divide, in the making of which the state is complacent (Abraham \& Van Schendel 2005). Abraham and Van Schendel (2005) identified societal and official legal mores as the two main sources of normativity in distinguishing between the (il)legal and the (il)licit in the analysis of authority, resulting in a quadripartite matrix of possible situations of authority. As they point out (2005: 19-20), social science theorists assume that people least favour a combination of the illegal and the illicit and strive to attain a state of authority in which the legal and the licit combine. Nonetheless, as the above propositions by Anders and Nuijten (2007) and Heyman and Smart (I999) make clear, the clarity of authority suggested when the legal and the licit combine is not favoured by all. It lacks the dynamism of authority that all other combinations retain, and although it is favourable to the imposition of the state-centred rule of law, some prefer to add their own laws to the ruling.

In our case at hand, authority is situated beyond the ideal combination of the legal and the licit. For over three decades, Indonesia was ruled by President Suharto's quasi-democratic New Order regime in which crony capitalism and patrimonialism combined in policies that were, as MacIntyre notes, 'largely unfettered by societal interest' (I99I: I7). Whereas the New Order regime had maintained centralised control over Indonesia, its fall was followed by the administrative empowerment of regional governments. These, in turn, where confronted by local customary leaders, religious authorities and others who had been silenced under the New Order but who used the power vacuum to regain their voices. Although many Indonesians aspired to a more open and democratic civil society, others distrusted the power of the state as a tool for the furthering of elite interests, as had been the case during the New Order. Local leaders, rather than faceless and 'foreign' bureaucrats, were considered the best option.

Throughout Indonesia, district populations aspire to become economically developed and to increase their wealth. Nunukan became an 
independent district in I999. Its government was bent on following a course of internationalisation through a revitalisation of trade and the provision of cheap labour and resources to lure foreign capital. The local government and the business community - which have a considerable overlap - actively promoted the possibilities of trade across borders as the district's future. Immigration and trade have been conducted in ways that are illegal according to the unyielding and anonymous rules of state law yet are considered legitimate in the local context, as they refer to continued practices and established traditions. The authorities regulating life and business in Nunukan hence are plural, comprising the authority of the state as well as local normativity. Each has its specific functions and limitations. The international border - a defence mechanism curbing foreign threats according to official law but an obstruction to regional networks in the local context - forms an arena in which these systems clash. Differing local and national interests subject the border's stopping powers and the impact of its enforcers to the countering forces of cross-border social and economic relations. The borders of authority go beyond the borders of the nation, just as authority itself goes beyond the state.

In this chapter we discuss the borders of authority and the fashioning of 'licitness' (Abraham \& Van Schendel 2005) by the authorities involved in the Indonesian border district of Nunukan. In this young district, local traditions, new trade opportunities and the remnants of New Order power structures make authority in the local economy and politics a coveted and profitable goal. Here the circumscribing framework of the Indonesian state is adapted to a local setting in which border-crossing actions and contacts are essential. From a state perspective, this is unsettling. This does not mean, however, that state authority is irrelevant. Nunukan's population is no united mass homogeneous in its actions and norms. Diverse and divided, population groups deploy state law and government authority in support of their own argument whenever this proves opportune. For the government, the possibilities of international trade could well make Nunukan a major economic hub in northern Indonesia. To the business community of the lowlands, the border represents a potential source of wealth. For poor Indonesian labour migrants, the border is a barrier to a (hopefully) better life abroad. For the Lundayeh community in Krayan, the mountainous western part of Nunukan, the border is a grey zone that offers opportunities for development and wealth but that has also led to a reshuffling of inter-Lundayeh power and economic strife. By comparing these two settings - lowlands and highlands - we aim to show the diverse usages and hindrances that the border poses as well as to discuss the discourses that sustain and oppose the border's authority. 
Whereas the border is an opportunity for the state to delineate and control access to its territory and obtain revenue through taxes, it also divides local communities, traditional territories and trade systems. To these, the border is a hindrance that urges parties to redefine transnational contacts and that alters the power relations between partners at respective sites. In the preceding chapters by Kalir and Ford \& Lyons, this powerful characteristic of national borders was all too clear. Whereas Kalir shows how Israeli nationalism and politics combine to prevent Chinese migrant workers from gaining a legal foothold in Israel, Ford and Lyons show how trade restrictions threatened to break up a well-established trading network between Indonesia's Riau Islands and nearby Singapore. Yet, like a big rock thrown into a small stream, the border does not halt the flow - it simply alters the course, speed and volume of it and possibly influences what is carried along, but the rock does not stop the water from passing. Kalir shows how a wide network facilitating and supporting illegal Chinese workers developed both outside and within Israel. Ford and Lyons show that the trade network has all but disappeared, even if the state defines these activities as smuggling. The passing of certain people and goods may be illegal according to official law; it is licit by local standards. But like leaves and branches that flow with the water in the stream, other things are carried across borders as well. Not all of these are licit or illegal, and their passing requires the constant attention of the authorities. Taking the international border between Nunukan and Malaysia as our point of focus, our attention lies with the manifestations of authority that the border generates. As the cases of the Chinese workers in Israel and the smuggling across the Singapore Strait illustrate, border crossings by people or goods perceived as licit by locals may overrule officialdom's definition of such crossings as illegal. We hence look for the authority that governs border crossings in Nunukan. We seek manifestations of its power and the discourses legitimising this power, in order to come to an understanding of the actual impact of the authority or - possibly authorities governing border crossings.

\section{Different Spaces of Authority}

Nunukan's I999 designation as a separate district inspired high hopes in the population for its ensuing development. The newly appointed district head, a well-known local businessman, saw a future for the district as a trading port focussing on the nearby Philippines, Malaysian Sarawak and more remote nations like China and Taiwan. Nunukan could export East Kalimantan's palm oil, coal, petroleum and especially timber to these economies. Also, the district government believed that 
Nunukan's ethnographic position as the Indonesian part of an economic triangle comprising Indonesia, Malaysia and the Philippines could make the district an attractive location for international firms and industries. Indonesia's large reserves of workers willing to work for low wages and the nation's flexible labour and environmental laws could make locating plants just across the border highly attractive for foreign firms, as the close economic ties between Singapore and the Riau Archipelago illustrate. Preferably, Nunukan's government would like to see a free trade zone established to facilitate such developments, but if this is not feasible, it feels the central government should grant the district special economic status in order to boost its chances of attracting foreign investment.

Nunukan's coastal and lowland area is largely focused on the regional capital of Nunukan city, situated on an island off the district's mainland coast a mere forty minutes by ferry from the Malaysian harbour town of Tawau. The population here is, in contrast to the highlands in the west, highly diverse. Representatives of East Kalimantan's major ethnic groups as well as substantial migrant communities live in this area. No community is sufficiently numerous to control all others, so social divisions run along the unifying lines of religion (Christianity and Islam, roughly a fifty-fifty division) rather than through the maze of entangled ethnic relations. This has two immediate consequences: first, religion became the balancing point in government. Both major religions need to have representatives in the regional parliament and among regional leaders. Too large a difference in the influence of one is bound to generate tension. Second, the absence of a majority ethnic group means that little attention is given to customary or traditional normativity in the lowlands. While there are groups that claim indigenous status and the ensuing privileges with regard to land or rights to natural resources, they are quite small and unable to exert sufficient influence.

The westernmost part of Nunukan consists of the Krayan plateau, a highland area that is bisected by the border between Indonesia and the Malaysian state of Sarawak. Krayan can only be reached from Nunukan's coast after arduous overland travel or, in recent years, by aeroplane. Krayan's population consists almost completely of ethnic Lundayeh - a collection of highland groups known commonly by this name to their lowland neighbours. The Lundayeh are an interior and mountain people. No roads reach Krayan and no river is sufficiently navigable. Krayan's population is largely governed by a customary social order which in the past was periodically reset by the competitive energies of families who organised large-scale mortuary and other construction projects. These events were often celebrations of successful headhunting raids on lowland peoples. 
The traditional social organisation of the Lundayeh has several specific characteristics of importance to us here: I) they emphasised common life over prestigious ritual occasions, 2) their system of social stratification was less rigid than that of many neighbouring groups, 3) the freedom to move away from a longhouse meant that chiefs had to compete for followers by sponsoring competitive feasts of prestige, 4) this made wealth important for the maintenance of status differences, 5) ambitious commoners could obtain wealth by capturing slaves, and 6) the plateau dwellers did not participate in the system of river-based politics and trade that characterised much of the rest of the island.

Prior to the arrival of Christianity, Lundayeh communities of northcentral Borneo maintained social distinctions through marriage, farming and language practices. Once missionaries introduced Christianity in the I930s, individual Lundayeh preachers brought the Christian teachings to communities throughout the Krayan Plateau, joining people together in a common, unifying practice. While the adoption of Christianity helped create community, allowing some more voice and agency, Christian practice also became another means by which to negotiate social distinctions.

In contemporary Lundayeh communities, people maintain forms of social practice of considerable antiquity. Social inequality is negotiated through a series of practices that are being adapted to fit within the cultural framework of modern Lundayeh society. The pre-Christian practice of slavery, for instance, continues to stigmatise unfortunate individuals who inherited this social status over succeeding generations. Careful attention to genealogies upholds class distinctions preserved through appropriate marital choice. Lundayeh in the Krayan plateau distinguish themselves as lun tana lun, lun nan ba', and leng ilu', labels referring to dialect, place and - in the recent past - farming practices. These distinctions have been expanded by those who migrated from this area to Malaysia in earlier times - using such terms as lun lod and lun bawang to denote place and dialect. Further distinctions are made according to one's social standing within communities - lun do' (for aristocrats), lun tap-tap (for common people) and, although not mentioned in public, demulun (slave). ${ }^{\mathrm{I}}$ Rather than a strongly unified and defined ethnic group, as lowland perceptions see them, 'Lundayeh' thus connotes a wide variety of ethnic sub-groups living on both sides of the Indonesian-Malaysian border.

Slavery was both a cause and a consequence of inter-community hostilities. These hostilities were driven by the attempts of some individuals to elevate themselves over others. In the past, the lun tanah lun, lun nan ba' and leng ilu' raided each other's communities as well as those of outsiders, practices that were only brought to an end by the imposition of colonial control. Capturing slaves, while always a sign of 
increased status of the owner, had different implications for the various sub-groups. The lun nan $b a^{\prime}$ were a social group farming permanent wet rice fields. ${ }^{2}$ In these communities, slaves were an essential part of the agricultural system that enabled slaveowners to grow crops on very large fields. ${ }^{3}$ The lun tanah lun were swidden farmers, whose hill farms required less labour. When the slaves were freed in the years just before the outbreak of the Second World War, the different economic importance of slaves in the lun nan ba' and lun tanah lun communities led to different choices by those who were set free. While most of the slaves of the lun tanah lun chose either to return home or to migrate to places in Malaysia, most of the lun nan ba' slaves elected to remain where they were, as they were given ownership of some of the fields they had worked.

Not long after Indonesian independence and some twenty years after the creation of the original highland church (KINGMI), a disgruntled church leader led the leng ilu' - the last converted communities - to form a separate church, Gereja Pemencar Indonesia (GPI). This church is viewed by the old guard lun tanah lun who control the KINGMI as 'a drinking and smoking church', practices frowned upon by these stern clergymen. The KINGMI is a largely lun tanah lun organisation. The last lun nan ba' leader, who served from I989 to I995, was evicted from his post over a scandal involving an adulterous relationship. In I998, he led Indonesian lun nan ba' communities into a new church organisation, the Gereja Bethel Indonesia (GBI). The GBI - a Pentecostal church - encourages clapping, emotional displays and speaking in tongues, all practices not accepted in the fundamentalist KINGMI. The GBI church has received spiritual support from the $b a^{\prime}$ dialect communities just across the border in Ba' Kelalan, Sarawak. These communities have been most active in the contestation over the direction of the Sidang Injil Borneo (SIB) church of Sarawak, the most influential church in the area. In Ba'Kelalan, SIB services began to include charismatic practices from the I970s onwards. These Christians are referred to as SIB baru, or new SIB. Those who continue to follow the more evangelical practices are referred to as SIB lama, or old SIB.

Lundayeh society is thus strongly divided by various churches' authorities and, as a result, by border-crossing tensions and alliances. The Sarawak SIB lama is aligned with KINGMI in Indonesian Krayan, while the SIB baru is comparable with the GBI. The tensions resulting from the schism of the KINGMI church in 1998 were expressed in very direct concerns. The Lun tanah lun feared that the lun nan ba' would rape their daughters, whereas the Lun nan ba' feared poisoning by the Lun tanah lun. ${ }^{4}$ To some degree, these tensions still exist in Krayan.

Whereas the ethnically and religiously heterogeneous lowland population largely looks towards the state as a main source of authority, the 
ostensibly homogeneous Lundayeh in Krayan are divided by a heritage of stratification that resulted in a plethora of church denominations. This fragmentation along sub-ethnic and religious lines suggests that the Lundayeh unity supposed in the lowlands of Nunukan is imagined. This suggestion, however, is quite far from the truth, as the Lundayeh are able to exert considerable authority over Nunukan society.

\section{State Regulation}

As in other parts of Indonesia, old animosities between communities have been exacerbated by the widely-held perception that the army and police have lost their authority, or at least their will to enforce it, following the end of Suharto's presidency. In Krayan, the state is represented by a number of police officers and army personnel. Their positions in Krayan are markedly different from the positions these authorities usually hold in Indonesian society. Police tasks and authorities are largely encapsulated in the domain of traditional Lundayeh leaders, the adat authorities. This means that the police are expected to respect and support the adat leaders rather than act as an independent authority. On the whole, the small and non-Lundayeh local police force has accepted this situation. For the most part temporarily stationed in the area, they see little point in upsetting the peace. A local officer told me how, in the I980s, a freshly arrived chief of police refused to comply with this arrangement and arrested wrongdoers while insisting he would not hand them over to the adat councils. The matter came to a head when rumours circulated that a Lundayeh detainee was about to be airlifted out of Krayan to stand trial at the district court. An angry mob removed the prisoner and torched the police station. The chief wanted his officers to resist, but the men, living in Long Bawan with their families, refused. Ordered to fire warning shots, the officer told me 'if we did, the people would think we were shooting at them, and while we have guns, so do they. They make guns themselves or have kept them from the konfrontasi [Confrontation] with Malaysia'.5 Police in Krayan thus have a pragmatic approach to their role. As official peacekeepers, they are asked to lock up drunks for the night and assist in settling minor misdemeanours if necessary, yet popular opinion keeps a tight rein on their authority. The station lies deserted after lunchtime, and it is rare to meet an officer in uniform in the afternoon. The officer referred to in the above situation explained that the population frowned upon an overzealous display of police identity, and wearing a uniform in the afternoon would solicit inquiries of 'whether one is up for promotion or just a show-off, to the merriment of all around. 
At Pa' Betung, the last village on the trail north from Krayan to southern Sabah, Malaysia, stands one of Indonesia's most remote poskamling, a type of security post set up by the government. A small, run-down shed, the poskamling stands vainly alongside the path just beyond the sign announcing the village of Pa' Betung. The Siskamling, an acronym for sistem keamanan lingkungan, 'environmental security system' was a programme begun in I980 designed to give police the responsibility for supervising village/neighbourhood security in order to extend state control over local security practices (see Barker 200I). Originally implemented to deal with security issues in Javanese cities, it was dutifully replicated throughout the provinces of Indonesia. By 2000 , the Pa' Betung post stood empty and crumbling, suggesting that the police policies of the regime had perhaps begun to erode at the margins long before they collapsed at the centre; or, more likely, they had never taken hold in villages such as these. ${ }^{6}$

The influence of Lundayeh adat leaders is surprisingly strong throughout Nunukan. With religious zeal, a strong appreciation of education came to Krayan. Many Lundayeh have received at least a primary education, and thanks to church and other funds, Lundayeh students are found at many of Indonesia's major universities. Upon the establishment of Nunukan as a district in I999, educated Lundayeh took up positions in the district administration as well as in its government. In 2006, Nunukan's vice-district head was a Lundayeh, as well as three members of its 25-member district parliament and several senior officials in the district administration: a strong position for an ethnic minority of less than ten per cent of the population. Lundayeh influence in official government was applied to obtain state recognition of the authority of adat leaders in Krayan and of Lundayeh control over most of the land in that area. ${ }^{7}$ For Indonesia, such legislation is very nearly unique. $^{8}$ It implies government permission for nearly autonomous non-state governance in an otherwise highly government- and stateoriented system of administration. The Lundayeh ensured the continuation of their customary authority as well as Lundayeh - rather than state - control over affairs in Krayan by the appropriation of administrative authority and its consecutive legal application. Such autonomy creates a position from which the width of the obtained authority may be further explored. For the Nunukan Lundayeh, the international border separating them from relatives and kin in Sarawak and the state authority that upholds it is a major focus. Along this material state border, the immaterial border of Lundayeh authority is sought and, where possible, expanded. 


\section{Exploring the Borders of Authority in Krayan}

Trade, intermarriage and social contact between the various Lundayeh communities on the Indonesian and Malaysian sides go a long way back. That an actual international border existed in the midst of Lundayeh society was made painfully clear during the military conflict of konfrontasi, which made 'Indonesia' as well as 'Malaysia' very real and absolute identities in the local imagination (Bala 2002a).

The border could not be closed. The first reason for this was because cross-border economic and social relations were of major importance to the Lundayeh communities on both sides - notably the economy on the Indonesian side was oriented towards Malaysia due to a lack of infrastructure down into Nunukan. The second reason was because enforcement of such a closure against the wishes of the population would require strong authority. The local police were not in a position to do so, and neither church nor adat leaders could support a measure that would isolate them from part of their support. Third, the remote and rugged terrain simply did not allow for it. As Poline Bala (2002b: I06), a Malaysian Lundayeh scholar, observed:

I still remember my first visit in I980 to the Berian area when I was about II years old. I went with one of my sisters and a few other children from my village ... We hiked up high mountains and climbed down deep valleys. When we reached the peak of Raan Mekang, a man in his 50 s pointed to somewhere on the peak and said ... 'That is the boundary line between Indonesia and Malaysia'. But all I could see were trees.

A 1967 border agreement between the Indonesian and Malaysian governments allowed local residents to cross the border for 24 hours and travel as far as five kilometres inland to trade, to work or to visit friends and family. They must report to the immigration authorities of both nations and are given a pass needed to re-enter their own country. ${ }^{9}$ As Lundayeh autonomy increased, however, the impact of this control system has seriously diminished. Amster (2006: 222) narrates how the two immigration officers on the Malaysian side were aware that 90 per cent of the Indonesians crossing the border would not register at their office or bother with a pass but that, as outsiders excluded from and unfamiliar with the local society, there was little they could do about it. The local population, border authorities on both sides know, feel that they have a right to cross the international border and will take it badly if, for whatever reason, this right is denied to them. Moreover, the rugged terrain and the unfamiliarity of the officials with the terrain make illegal crossings very easy. 
In Krayan, the international border is thus a mark of state authority that is largely ignored by the local population. Trade, labour and people pass under the supervision of adat authorities, a system that is deemed far more efficient and just and, moreover, a customary right of the population.

For decades, rice farmers on the Malaysian side have been dependent on assistance from relatives in Krayan, for whom the strong economy of Malaysia provided enticing possibilities. This was noted by Ahmad Bintoro, a journalist for Ambon Nasional Newsletter sent to Krayan to report on a passenger plane crash on I4 July 2002. ${ }^{\text {IO }}$ Bintoro titled his piece Richest People in Indonesia? and constructs an image of Krayan through what Soja (I989) calls a geography - a spatial and social distribution of wealth, power and point of view. Bintoro described the villagers as using aeroplanes everywhere they go, even to buy cigarettes. The high costs of basic necessities did not bother these people, as they use the strong Malaysian ringgit rather than the Indonesian rupiah, and they frequently cross the international border to go shopping in Ba' Kelalan, a Malaysian border village he imagines having paved roads and a shopping centre. In their isolation, the 'flying everywhere' people of Krayan can only receive Malaysian radio and television, and whereas they know the names of Malaysian politicians, they do not know the name of the governor of East Kalimantan. He concludes by quoting the headman of Long Midang, Krayan's border village: 'for us, they [the Malaysian relatives] are no foreigners, rather we all feel like foreigners in our own country'. From the article, it appears that Krayan is too far from Indonesia and too close to Malaysia. This tongue-in-cheek article by a lowland Indonesian captures the essence, if not the actuality, of a region whose economy is Malaysian, not Indonesian.

Krayan exports rice and buffalo to Malaysia, while Krayan villagers (including school teachers and other civil servants) supplement their income through seasonal labour in Malaysia. This brings considerable sums of ringgit into Krayan, a hard foreign currency that makes the area quite wealthy by Indonesian standards.

Yet whereas established, customary relations used to govern these cross-border relations, these relationships are being put under increasing pressure from a non-traditional authority. In 2003, a road was constructed that connects the Malaysian town of Ba' Kelalan to Long Bawan, the capital of Krayan. Ba' Kelalan is the major market town for Long Bawan and in the past, people from Krayan would come here to sell their surplus rice and buy supplies. Krayan's fine grained and aromatic mountain rice is much in demand throughout Malaysia. As Ba' Kelalan is connected by road all the way to the coastal area, traders would sell the rice to coastal buyers at a handsome profit. The new road, however, allows coastal buyers to drive all the way up to Long 
Bawan, passing the international border by the authority of Krayan adat leaders, and buy straight from the source, thus cutting out the middlemen. Lundayeh at Ba' Kelalan responded by setting up toll gates and levying a fee on everyone wanting to pass using a motorised vehicle, regardless of whether they are Malaysian coastal traders or Lundayeh from Indonesia. Moreover, Indonesian Lundayeh are required to leave their motorbikes or cars - needed to transport the rice - before crossing into Malaysia or risk being denied access to the village's shops. This was a measure the Ba' Kelalan community introduced as an additional safeguard to maintain their rice trade. Obviously, this has caused much chagrin among the Indonesian Lundayeh, who consider it humiliating to be made to drag their purchases, which may vary from foodstuffs to plastic piping or other building necessities, through Ba' Kelalan's main street in what they see as a wanton abuse of power by the Malaysian Lundayeh.

As adat authority did not suffice to solve this problem, Indonesian Lundayeh appealed to official authorities on their side of the border to assist in settling the problem (Ardhana, Langub \& Chew 2004: I70I73). Yet both Indonesian and Malaysian officials maintain the stance that it is preferable for parties to reach an agreement without government intervention.

Solutions to the trade dispute are being sought in the establishment of alternative border crossings which, however, is largely drawn up along sub-ethnic lines. Lun tanah lun actors envision a road that would connect Long Umung, the largest lun tanah lun village in Krayan, with Long Pa' Sia' in southern Sabah. The largely lun nan ba' populations of Long Bawan and the villages surrounding it favour improved road connections to Ba' Kelalan, notwithstanding the present difficulties. Krayan's leng ilu' imagine a road linking southern Krayan with the Kelabit communities in Bario, Sarawak. Each ethnic sub-group sees the potential of running the rice trade as well as the dangers of other subgroups snatching this economic opportunity.

Similar exercises of the imagination are occurring across the border in Malaysia, where the various Lundayeh counterparts are taking an avid interest in development. A Malaysian coastal contractor invited to start work on the Long Umung - Long Pa' Sia' road by Indonesian adat leaders with the agreement of Krayan's government authorities found his access to the area barred when the lun nan ba' population in Ba' Kelalan refused to allow his heavy equipment into Indonesia for fear of losing their market position. After interference by adat and official authorities, the path into Indonesia was cleared, yet work on the road is progressing slowly.

In recent years, an increasingly secure Lundayeh autonomy in Krayan has led to local perceptions of police or military authority 
changing from being potential threats to adat authority to protectors of local security. The various Muslim terrorist bombings that have hit Indonesia have caused unease in Krayan, which is staunchly Christian. Whereas Nunukan's seaport and lowland border receives extra police attention, the long highland border is difficult to guard given the forested and hilly nature of the terrain. Although the likelihood of foreign terrorists undertaking the difficult and far-from-anonymous journey through Borneo's interior seems remote, rumour in Krayan has it that regional Muslim government authorities are unwilling to allocate resources to guarding Christian areas. Long Bawan's police have risen to the occasion, emphasising their role as protectors of the local population. A close screening of all non-local, non-Lundayeh individuals entering Krayan from Malaysia is maintained, giving these state authorities a more prominent role. The fact that they, rather than the adat or church authorities, are given this important task implies an increased role of state authority. As Krayan's sub-district head argued, cross-border kinship values are decreasing under the pressure of trade competition and church differences. This opens up space for new allies, and the state whose authority Lundayeh officials in Nunukan's parliament have shown to be able to harness - is a welcome candidate. When ties to Nunukan prove secure, what is to stop the Lundayeh of Krayan from leaving their soured relations with Malaysia's Lundayeh and expanding their business network beyond traditional authority?

\section{Material Uses in the Lowlands}

Even though both areas are part of a single district, Krayan's customary governance is a world apart from the practice of authority in the lowlands. A number of Lundayeh politicians represent the interests of customary authority in parliament, but they discretely refrain from arguing its importance in lowland multi-ethnic society. Authority in lowland Nunukan is therefore presented as a government affair, but some shading is in order. Nunukan's regional government advocates an official reduction of the limitations posed by the international border in order to boost the district's economy, a decision that is to be made by higher government. Unofficially, however, the border's limiting abilities are already decreased and generate substantial financial profit.

Frequent ferries run between Nunukan and the nearby Malaysian city of Tawau. Indonesians in search of work regularly use this route to enter Malaysia using visitor visas, to be subsequently engaged as cheap labourers in Malaysia's plantations, which is illegal without a working permit. Authorities in East Malaysia regularly round up illegal Indonesian workers and deport them to Nunukan (Tirtosudarmo 2005: 
I72-I80). In 2002, Malaysian authorities surprised Nunukan's authorities by deporting thousands of illegal Indonesian workers through Tawau in a few days' time (see Kompas, 20 August 2002). Arriving destitute, many with only the clothes they wore, this wave of people engulfed the district government's capacities to provide food and shelter. Because national aid arrived too late, at least 85 deportees died and outbreaks of various diseases in the emergency camps were barely contained (see Tirtosudarmo 2004). Although such Malaysian reactions have had Nunukan's migration officials step up their control of Indonesians wanting to pass the border, illegal border crossings still take place.

The Sebuku river is one of Nunukan's major traffic arteries. It runs almost parallel to the border for much of its course. On the Malaysian side, a road follows the border and at long stretches road and river are separated by nothing but a stretch of forest. Pathways - some just footpaths, others allowing for small trucks - known as jalan tikus (mouse trails) connect road and river (see also Kompas, 30 August 1999). When migration controls in Nunukan's harbour were intensified, illegal crossings moved inland. These illegal crossings are arranged by IndonesianMalaysian teams from both sides of the border and are a profitable business. As a migration officer pointed out in 2005, many officials are willing to look the other way in exchange for a bribe. Aspiring migrants pay substantial sums to touts offering work in Malaysia. If a group of migrants gets caught by Malaysian police and deported back to Nunukan, they would rather incur greater debt with local touts and try to cross again than return home empty-handed. This means that Nunukan's authorities would need to escort illegal immigrants back to their areas of origin to effectively counter illegal immigration - a costly affair that is in Malaysia's interest but not in Nunukan's interest.

Not only migrants move along the mouse trails. Logging is a major industry in Nunukan and the proximity of Malaysia's insatiable industries has given rise to an extensive problem of illegal logging. The smuggling of illegally logged wood from Indonesia to Malaysia is a well-known problem throughout Kalimantan's border areas (Wadley 200I; Obidzinsky, Andrianto \& Wijaya 2006). Logs are smuggled along the mouse trails, although local authorities believe that the majority of smuggling is carried out by using the extensive coastal delta of waterways, islands and inlets that separate Nunukan from Tawau (see Jakarta Post, 7 April 2004). Nunukan police and customs officials have confessed that they are practically powerless due to a lack of personnel and equipment (Tempo, 2I September 2005) as well as the smugglers' backing by government officials. ${ }^{\text {II }}$ According to Nunukan's chief of police, illegal logging was the most common crime in the district in 2007 , and 
strong countermeasures were direly needed (Radar Tarakan, 2 January 2008).

Research indicates that most illegal logging is carried out not by bands of log pirates roaming Northeast Kalimantan's forests but by official logging operations working beyond their concessions or working the area on the pretext of carrying out other work (Barr et al. 200I: 2527; Obidzinsky et al. 2006, 2007: 528-530). ${ }^{\text {I2 }}$ In Nunukan, the practice is quite common. Hidayat (2005: 245-247) has shown that Nunukan visibly exports extensive quantities of logs, but its government books show virtually no income from logging. Where, he wonders, does the money go? Officials maintain that the smuggling concerns Malaysian intrusions in which teams of loggers enter Nunukan by way of the mouse trails, log as many trees as they can move and retreat across the border with their prize. Malaysians are suspected of a substantial encroachment on Indonesian soil as well. In a recent report, the National Planning Agency (Directorat 2006: 22) points out the need to reorganise the border to guard against further intrusion:

Slack control of the national border allows specific parties from national or international origin to move border markers. At various oil palm estates managed by Malaysians, movements of border markers are often carried out to expand their territories. This situation is possible because the area on the Indonesian side is a protected area that cannot be utilised or managed by the local people and hence is not felt to be territory of the Republic of Indonesia. ${ }^{\text {I3 }}$

The National Planning Agency therefore argues that the border area should be turned from a cluttered forest zone into a long gird of palm oil plantations (Direktorat 2006: 53-60). Orderly arranged plantations will bring employment opportunities and be easier to patrol and guard against clandestine Malaysians entering Indonesia than the present forest border is. The scheme has the consent of the local business elite who would likely be the main beneficiaries of the logging concessions in the protected forest area as well as the plantation concessions.

The official discourse here positions the present porous state of the border as a threat against Indonesia's economic and territorial welfare that is being exploited by Malaysians. ${ }^{\text {I4 }}$ Indonesians, the discourse implies, would do no such thing, which clears Nunukan's elite of any involvement in illegal actions. Yet if we accept Hidayat's observation mentioned above, it seems fair to assume that not all logs are purloined by raiding Malaysians and that local involvement and patronage do exist. Likewise, relevant officials could probably reduce the number of 
illegal immigrants considerably if enticements to do otherwise were absent. That such enticements exist is no secret.

Located on the outskirts of the Indonesian state, the demonstrations and riots leading to the end of Suharto's presidency passed over Nunukan relatively unnoticed. What did change, however, was the structure of power. Upon becoming a district, Nunukan's major government positions were initially occupied by individuals with local administrative experience acquired during the New Order or by persons from the local elite. The anti-New Order activists and opposition leaders who came to the fore in many other parts of Indonesia were absent in Nunukan's government, which was mainly formed out of local bureaucrats, rich traders and other members of the New Order-era local elite. The patrimonial style of government characteristic of the New Order is therefore quite visible in Nunukan's arrangements as well. The district head is one of the richest traders and landowners of the district and is involved in all major business developments that take place. Should the border indeed be converted into a strip of oil palm plantations, it is this local elite that will profit. It seems highly unlikely that illegal immigration and wood smuggling could take place if local government really sought to combat it but, as police and immigration officials alike pointed out, these 'businesses' enjoy protection from powerful local individuals. The elite, it seems, seeks profits, and a government position is one way of ensuring the arrival of these. The New Order may have fallen, but its authority structure still echoes in this rich but remote part of Indonesia.

\section{Concluding Remarks}

Nunukan serves as an example of the conditions in regions throughout Indonesia where the fall of the strong and centralist New Order regime created a power vacuum that could be filled by local authorities. In Nunukan, the New Order has not been replaced as thoroughly as in other areas. An initial reason may be the fact that Nunukan did not exist as an individual district until after Suharto stepped down. The district therefore had no high-level government officials clearly associated with the regime. As New Order officials were absent, so were their opponents. As a result, the group best positioned to arrogate government authority - Nunukan's lowland trading elite - implemented government authority along New Order lines with an emphasis on personal interest and a certain level of immunity from the law for high officials' illegal activities. This appropriation of state authority protected elite interests but also deprived potential opponents from its usage. 
Nonetheless, state law is not the exclusive legitimising domain of the lowland elite. Krayan Lundayeh have likewise applied the state's authority to substantiate the autonomy of their own competitive non-state authorities - those of the adat and church leaders. Although these authorities derive their power from non-state sources, they are nonetheless strengthened by state legitimation.

In Nunukan, the international border is crossed by a multitude of goods, people, labour, cash and power, often as part of non-official, formally illegal exchange systems more profitable, practical or longer established and more widely accepted than state-prescribed rules. These conditions accentuate the weak position of the state in directing and controlling flows. When the borders of state authority gave way, its powers were absorbed to strengthen other spaces of authority. The various authoritative systems that appropriated the government authority that was invested in the district of Nunukan in the name of the Indonesian state thus exist in a symbiotic and benevolent relation with this national authority. Illegal and illicit smuggling in the lowlands is transformed by the cleansing power of government-associated protection, while far-reaching claims of indigenous autonomy and the harnessing of local state power in Krayan are considerably strengthened by official government approval.

What our findings indicate is the importance of the temporal dimension in studying licit-illicit and legal-illegal constellations and the authorities governing them. As is the case in the chapters by Kalir and Ford \& Lyons in this volume (although not the main focus there), we see shifts in the power of authority as well as in actual discourses of authority taking place over time. These changes are important in understanding the present state of authority over border crossings in Nunukan, but they also may serve as an indication of the potential strengths and weaknesses in the authorities' current positions. Local positions of authority must be maintained with an eye on larger developments, such as the fall of the Suharto regime. As state and non-state discourses drift apart or merge to form new alliances, local-level authority has shown itself to be capable of dynamism, absorption and change in order to maintain or strengthen its position.

\section{Notes}

I However, in the context of contemporary Christian discourse, the term is used to refer to hamba tuhan, slaves of God.

2 For various discussions of the relationship between slavery, hierarchy, debt and obligations, see Reid (1983).

3 For descriptions of the lati ba', see Padoch (1983) and Crain \& Pearson-Rounds (I999b). 
4 These fears mirror the perceptions of each group of the other. The lun tanah lun see the overtly emotional qualities of the GBI as reflecting the unfettered sexuality of the lun nan $b a^{\prime}$. The lun nan $b a^{\prime}$ ascribe knowledge of magical poisons (whose origin is in the forest) to the lun tanah lun, whose traditional economy placed them in the forest.

5 See Conboy (2003: 99-I03, II5-I7) on konfrontasi - an unofficial border war between Indonesia and Malaysia between 1963 and 1966 - and on events in Long Bawan. Conboy (2003: 175-176) cites an Indonesian army officer who reports that local militia and volunteers were very willing to hand in arms distributed by the Indonesian military. Yet several informants confirmed (and proved to me) the police officer's statement that guns are present among the area's population. These seemed to be local products, however, rather than professional military arms.

6 By 2005 , the post had all but disappeared.

7 District regulations 3 of 2004 and 4 of 2004 were passed by Nunukan's parliament to this end. See Bakker (2008) for a more extensive discussion.

8 Only one other example of such legislation - the Badui in the district of Banten - is known to us.

9 See Bala (2002a: 8I-85) for a detailed discussion of the border agreement.

Io See Crain and Pearson-Rounds (2005).

II The following anecdote may serve by way of illustration. While in the village of Pembeliarang, halfway up the Sebuku river in 2005 , I was surprised one morning to see a military landing craft passing by. Local authorities told me the landing craft was manned by immigration, forestry and police officials on their way to confiscate a bulldozer and other heavy equipment used in illegal logging further upriver. When I asked how these had gotten there, way up in the middle of nowhere, I was told that they were brought by possibly the same military landing craft and that it was common knowledge that they were there. Locals suspected that the district elite was reshuffling its internal power relations and that the seizure of the equipment was part of this.

I2 Before being convicted for corruption because of his role in a scandal related to illegal logging and a planned one-million-hectare oil palm estate, East Kalimantan governor Suwarna Abdul Fatah called for illegal loggers to be given the death penalty (Kompas, 2 August 2004).

I3 'Protected area' (kawasan lindung) refers to a status designated to forest by the Ministry of Forestry. Logging, other permanent economic activities and habitation are not allowed, thus making all such activities stand out as obviously illegal.

I4 The extradition of illegal Indonesian workers to Nunukan is explained in a similar vein by emphasising their helplessness and the need for elementary human necessities which Malaysian customs and police denied them. 


\title{
6 Bamboo Baskets and Barricades
}

\author{
Gendered Landscapes at the India-Bangladesh border
}

\author{
Malini Sur
}

\section{Introduction}

My contribution argues for plural engagements with undocumented border crossings. I posit that trans-border mobilities, especially in regions where borders divide similar societies, are located at the intersection of sovereign violence and social legitimacies. This paper explores such intersections by following bodies in motion, and bodies that are selectively intercepted and deported at the heavily patrolled and militarised India-Bangladesh border. I advance that borders have lethal yet fluid dispositions. The aggressive policing of borders coexists with local and trans-border legitimacies that accommodate undocumented border crossings.

Illustrations from the highly secured United States border with Mexico expose how border controls enhance the visibility and performance of policing rather than actually reducing clandestine migration and smuggling. State visibility at borders induces more sophisticated ways of moving people and commodities, often escalating the risks involved by dependency on brokerage and dangerous journeys (Andreas 2000: 8-9; Nevins 20I0: I4). Often because borders and border crossings are projected as lethal, migration laws impede women's transnational mobility under the guise of protection. For instance, women's labour migration is frequently restricted or prevented by framing them as infantile, victims or docile citizens. Such restrictions compel women to undertake dangerous forms of migration (Kapur 2005: II8; Kodoth \& Varghese in this volume).

That militarisation and border violence provoke scholarly engagements with migrant deaths, bodily abjection and the sexual oppression of women is not surprising. These are global border conditions. The India-Bangladesh border is no exception. India is constructing a new high security border fence with Bangladesh, a neighbouring country that is increasingly imagined as a shelter and conduit for terrorism. In the past decade, at least one unauthorised border crosser on average has 
been shot to death by Indian border guards every third or fourth day at the India-Bangladesh border (Human Rights Watch 2010). Scholars have called this a 'killer border' (Van Schendel 2005: 296) and depict this region as a liminal zone of 'exception' (Jones 2009: 889). Several stretches of the India-Bangladesh borderland function as a source and transit area for sex trafficking. Endemic poverty, social imbalance, political violence and militarisation marginalise women, especially those belonging to minority communities (Banerjee 20IO: II5).

Set against this violent landscape, this essay argues that body politics at borders have expansive connotations and are not only confined to the sexual oppression of women. My contribution compares the border crossings of women traders and men labourers who navigate India's partly constructed new border fence and armed border guards. While I do not question existing depictions of the India-Bangladesh border as gruesome and violent, I depart from and challenge the concomitant framing of militarised borders as spatially and socially liminal and sexually predatory zones for women. This paper illustrates how local and trans-border legitimacies sustain the circulation of commodities and labour flows at the India-Bangladesh border. These legitimacies are informed by historical and material ties as well as overlapping social affinities. Trans-border mobility is only occasionally influenced by bilateral agendas and by India's security centric discourse that officially equates all undocumented migration from Bangladesh with threats to national security.

My contribution straddles the theme of border violence and the production of licitness (Abraham \& Van Schendel 2005) that link this collection of essays. If scholarly engagements with border violence draw attention to borders as zones of danger and emphasise the excessive use of force at borders (Van Schendel 2005; Jones 2009), engagements with legitimacies expose the fluid and shifting dispositions of militarised borders. Abraham and Van Schendel (2005) argue that spaces like borderlands facilitate and cushion what is mostly tainted as 'illegal' flows, and that states often project such flows as politically subversive. They also posit that notions of illicitness are ephemeral and frequently change (2005: 23-24). In this essay, I argue that licitness that facilitates undocumented trans-border mobility creates its own genre and logic of violence. Such ecologies of licitness, generates conditions in which border violence is not protested.

Engagements with local and trans-border permissiveness and the unequal power relations between border guards and trans-border travellers challenge two dominant representations of violence on the IndiaBangladesh border. First, it unsettles the representation of women's bodies at militarised borders as sexualised, dehumanised and exploited. As Pattadah and Moors remind us in the following chapter, academic 
discourses remain content to frame men as economic migrants and women as unwilling and disempowered migrants who are sexually exploited by unscrupulous traffickers. Therefore, broadening the scope of women's transnational mobility and understanding how and why women are able to negotiate a militarised border region are imperative. Second, this essay advances that the India-Bangladesh borderlands are zones of non-deportations and selective deportations. National security and border-enforcement agencies in India constantly underscore the challenges and the near impossibility of deporting 'illegal Bangladeshis' who are imagined as arriving in India surreptitiously and taking advantage of ethnic, religious and linguistic affinities to acquire citizenship. However, I show how border patrolling and deportation agendas are led by a specific profiling of 'illegal' Bangladeshis that is informed by ethnicity, religion and gender as well as local demands for cheap commodities and labour. Selective deportations at the India-Bangladesh border reflect the convergence of aggressive border policing and militarisation with local legitimacies, labour extraction and commodity circulations.

My main claim is that the production of social legitimacies that accommodate undocumented labour and commodity flows is intertwined with border violence in complex ways. My assertion rests on the transborder lives of adivasi 'indigenous' Bangladeshi Garos who trade, labour and transit through a border town in Northeast India that I fictitiously call Domachi. ${ }^{\text {I }}$ At present, the town has a population of a little over eight and a half thousand people, including the demographically significant Indian Garos. Domachi is located in the state of Meghalaya in Northeast India. Northeast India is a region that is connected to mainland India through a narrow corridor and has been labelled a zone of political dissidence by India. It shares international boundaries with Burma, Bangladesh and China (Map 6.I depicts the border region that includes Domachi).

In India, the presence of 'illegal' Bangladeshi foreigners is politically explosive. It is tied to issues of land loss, demographic imbalance and the fraudulent acquiring of Indian citizenship. ${ }^{2}$ The image of the 'illegal Bangladeshi' in Domachi (Northeast India) is male, Muslim and Bengali, similar to pan-Indian discourses. However, Domachi's historical and material affinities with the Mymensingh district in Bangladesh make the borderlands of Northeast India and Bangladesh a fluid zone for non-Muslims. Thus, concerns about 'Bangladeshi infiltration' and 'Islamic terror' in many states of Northeast India co-exist with the everyday transnationality of 'indigenous' groups, who are non-Hindus and non-Muslims (Hindu and Muslim being the two majority religions of India and Bangladesh respectively). ${ }^{3}$ The trans-border lives of traders and labourers as everyday and occasional commuters also unsettle the 
Map 6.1 Map of Northeast India and Bangladesh

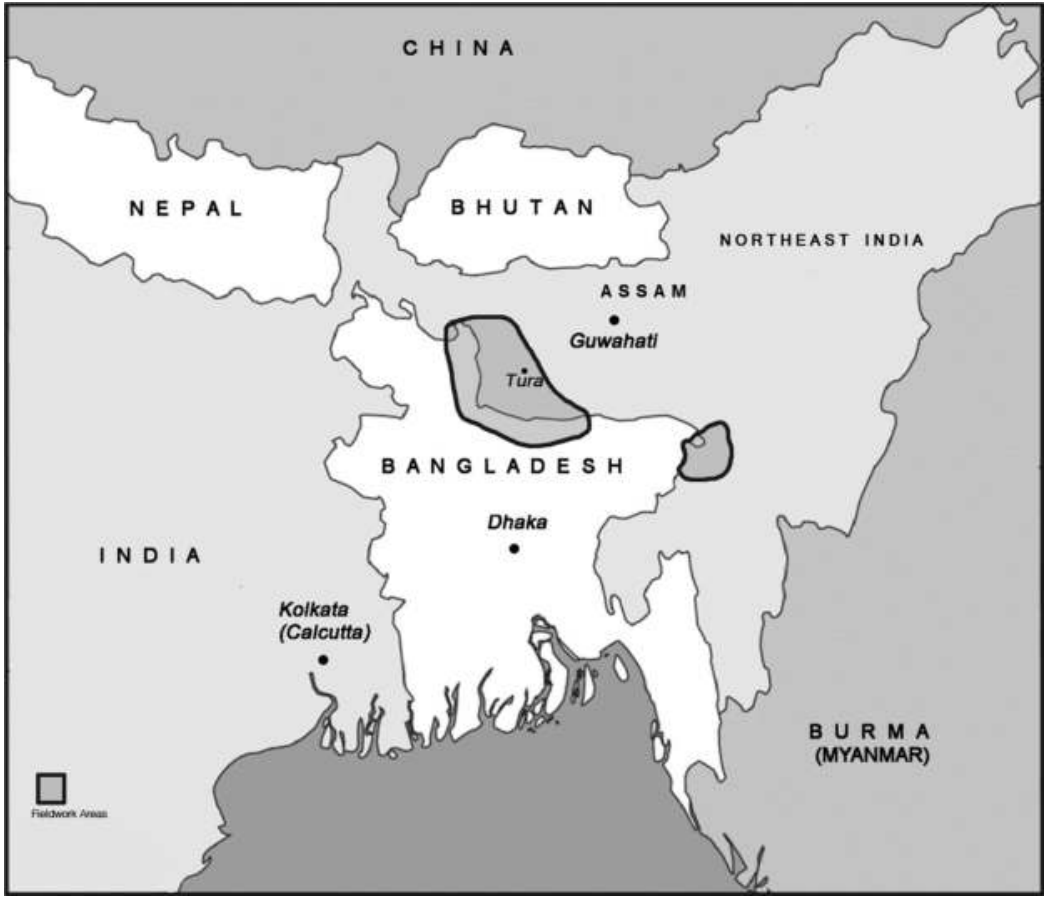

mostly well-established links between migrant claim-making and political membership and citizenship.

The trans-border mobility of the Bangladeshi Garos in the region must be seen against the overall declining male mobility of Bangladeshi Muslims and Hindus to Northeast India, who remain policed as 'Muslim terrorists' and poor low-caste Hindus who desire to settle and acquire citizenship, respectively. Bangladeshi Garo women's trans-border lives, which I contrast with Garo men in this paper, must also be viewed against the overall declining role of Hindu and Muslim women in trans-border trade and travel in this hilly and forested border landscape. The following sections of this paper offer insights on gender, borders and transnationality through the trans-border journeys and lives of Bangladeshi Garo traders and labourers. By comparing the border crossings of subsistence traders, daily wage workers and coal miners who travel from Bangladesh to Domachi, Northeast India, this paper exposes how religion, gender and ethnicity influence border controls. Though this paper is geographically limited to one specific zone, mundane border crossings and selective deportations are widely prevalent in the Northeast India-Bangladesh borderlands. ${ }^{4}$ 


\section{Gender, Borders and Transnationality}

More than twenty years ago, in an important collection of essays, Yuval Davis, Anthias and Campling (1989) argued that women's roles as biological reproducers of ethnic groups and national groups ensured that they remained integral to nation-building (I989: 8-9). The brutal abuse of bodies, especially women's bodies, in political formations as objects of community and national honour and as victims of sexual slavery convey why discussions about borders cannot escape engagements with the body. These attune to Donnan and Wilson's claim that 'forces that demarcate geographical and political space as lines on a map simultaneously inscribe the body's topography' - hence their apt framing that 'border maps are also body maps' (I999: I29).

The horrors of partitions and wars in South Asia led to sexual violence. The bodies of religious and ethnic 'others' - men and women were transformed into objects of mutilation and torture. Political formations and state-building were accompanied by large-scale rape and forceful religious conversions (Menon \& Bhasin I998; Butalia 2000; Bagchi \& Dasgupta 2003; Mookherjee 2008). The appropriation of women's bodies did not end with new state formations. Rather, their violent recoveries and ambivalent rehabilitations became a part of nation-building and modernity rather than human emancipation (Menon \& Bhasin I998: I24-I26; Mookherjee 2008: 48-49). Furthermore, the marking of zones of political dissidence like Northeast India by India and the Chittagong Hill Tracts by Bangladesh has been accompanied by sexual violence directed against women of minority communities (Banerjee 2010; Amin 2004; Guhathakurta 2004).

Research on gender, borders and sexual violence needs to be complemented with other narrations of bordering, especially with ones that locate women's undocumented mobility in partitioned and militarised landscapes. The consequences of the partition of India in 1947 and border-making in more recent years have been different for non-Hindu and non-Muslim border communities like the Garos. Unlike many communities who experienced the partition as a one-time displacement and relocation followed by a rapid sliding into formal legal citizenship, several others - especially those who lived close to the border - experienced political transformations and border-making through multiple displacements and relocations for many decades (Van Schendel 2005: 46-49; Bal 2007: I60-I7I). Partly as a consequence of these displacements and relocations, and despite border militarisation, the Garos who live along what is today the borderland of Meghalaya in Northeast India and Mymensingh in Bangladesh lead transnational lives (Sur forthcoming). 
Especially the everyday commuting of women in the heavily militarised India-Bangladesh border, counter narrates the strong association between women's bodies and borders as sexualised. My claim is not that partitions and wars did not lead to the sexual oppression of Garo women (of which there has been little investigation). Also, I am not disputing that Garo women do not experience sexual harassment and the threat of rape at borders. Instead, what follows aims to demonstrate that even heavily patrolled borders where the threat of rape and sexual oppression is never out of context are gendered and more fluid than conventionally imagined. In militarised landscapes where men are profiled as 'terrorists and infiltrators,' their trans-border mobility shrinks. Militarisation curtails men's undocumented mobility and disciplines their labour. Simultaneously these political conditions create new possibilities for women's unscripted journeys.

Border control in this partly forested and agrarian landscape illustrates the careful screening and the highly selective deportations of 'illegal Bangladeshis'. In India, deportations of 'illegal' Bangladeshis are mainly directed at impoverished Muslims. There are many historical and contemporary precedents of deportations in India, which remain haunted by 'cartographic anxieties' (Krishna I994). India has a history of deportation drives against 'Pakistani and Bangladeshi Muslim infiltrators and spies' since the I950s. Hindu-Muslim riots in the I96os also provoked fresh rounds of deportations of Muslims from many states in India, including states in Northeast India aided by special legislations (Sur forthcoming). In the decade of the I990s a programme of aggressive eviction and deportation known as 'Operation Pushback' was devised. It was mostly directed at Bengali-speaking Muslims and Bangladeshis living in squatter settlements in New Delhi (Ramchandran 2003: 325-326). These deportation drives landed many 'suspected Bangladeshi' immigrants in the 300 yards border zone between the two states and also entailed the harassment of impoverished Indian Muslims (Ramachandran 2002: I8, 2003: I50; Roy 2009: I7). Along the international boundary in India, are ad-hoc deportation checkpoints called 'push-back' centres. Though lacking legal basis, they have been institutionalised and reflect normal bureaucratic functioning.

As a response to India's 'push-back' strategy, Border Guard Bangladesh, the state-led border organisation in Bangladesh, has developed 'counter push-in' functions. Bangladesh refuses to accept people stranded on no man's lands as Bangladeshi citizens. The country condemns the frequent physical pushing out of people labelled as 'Bangladeshis' into the border zone between the two countries. The physical pushing out of suspected Bangladeshi foreigners from India and Bangladesh's strategy of refusing them entry into Bangladesh lead the politics of territoriality at the India-Bangladesh border zone at an 
official level. These struggles also reflect the ambiguity of border identities at the India-Bangladesh borderland, where neither citizenship nor migrant illegality can be easily established (Sur forthcoming). Meanwhile, political elites in Bangladesh are not concerned about impoverished Bangladeshis in India. This is because they are seen as lessskilled and bringing in little remittance as compared to Bangladeshi immigrants in the Arabian Gulf and Southeast Asia (Khan 2010: 9I).

It has been established that Muslims - as a religious minority and as border residents in India - face threats of deportation and border violence. As De Genova and Peutz remind us, deportations are not just functional acts of states but reflect a complex socio-political regime, inter alia, resting on dominant notions of sovereignty, citizenship, national identity and racial purity (20I0: 2). While for De Genova and Petuz, it is pertinent to locate how deportation regimes become a universal marker of exclusion and brings with it extreme violence and erosion of rights, my concern is with the gendered and highly selective nature of deportations at the India-Bangladesh border. I analyse the politics of non-deportations and selective deportations that guide the transnationality of the Garos. Such forms of border politics reflect the gendering of border controls, the fluid disposition of militarised borderlands for some borderlanders and the non-condemnation of border violence that falls outside negotiated arrangements. Abraham and Van Schendel's formulation of the 'illegal but licit' as a framework captures how social life operates simultaneously at many levels and scales is especially relevant to the study of trans-border flows and selective deportations (Abraham \& Van Schendel 2005: 22-25).

The border crossings of many non-Hindu and non-Muslim groups who inhabit this border region draw from notions of shared histories and geographies, where moving from one part of the borderland to another despite the imposition of new border fences and heavily armed border guards is not an aberration for either states or for borderland communities. As the subsequent sections of this paper make evident, Domachi remains a relatively quiet region of mobile and disciplined bodies within a larger zone of terror and dissidence.

\section{Domachi}

The Domachi market bursts into commotion twice a week. An otherwise sleepy border town then transforms into a bustling hub for trade and socialisation. In the early mornings, trucks carrying cement and gravel from the district headquarters come to a screeching halt at the entrance of the market. Daily wage labourers, mostly migrants from other states of northern India and Bangladesh, anxiously crowd around 
contractors and brokers. At frequent intervals, Indian border guards with guns and wireless radio communicators stride in and out of the market. They look out for 'suspects' and 'infiltrators' and occasionally negotiate for grocery purchases for border outposts where they reside. Meanwhile, Indian and Bangladeshi subsistence traders squat in designated places and spread out their merchandise. As foreigners, Bangladeshi traders cannot own or rent stalls. Since Indian Garo traders own and rent stalls in border markets in Meghalaya, they seldom travel to Bangladesh to procure goods. However, like Bangladeshi Garos, Indian Garos frequently travel to Bangladesh for shopping and maintaining kinship ties.

From the southern end of the market, a new border fence is visible. In Domachi, the construction of India's new border fence with Bangladesh started in 2006 . The hilly landscape is intersected with metal pillars and new roads. The border, partly a mud path and partly tarmac, remains congested with labourers, engineers and border-patrolling officers who oversee the construction work of the fence. In their midst, women with bamboo baskets and cloth bags and men with shovels and sickles cross the international boundary. They pass by the border outposts in Bangladesh and India.

India's border fencing project with Bangladesh, led by the federal government of India, was initiated in I986 (Van Schendel 2005: 212) to contain threats to national security and prevent smuggling. Of the total length of the India-Bangladesh border that Indian proposes to fence (3286.87 kilometres), almost half passes through Northeast India. Fencing has not been undertaken in other areas on account of low-lying areas or river borders, villages located within I50 yards of the border, and land dispute cases between the federal government of India and states in Northeast India (Ministry of Home Affairs India 2005-2006). ${ }^{5}$

The India-Bangladesh border is a legacy of the partition of India. In I947, the partition of India placed the international boundary between India and Pakistan (East) through Domachi. The partition of the Indian subcontinent into a 'Hindu' India and a 'Muslim' Pakistan resulted in an ad-hoc boundary (Map 6.2). The partition boundary disrupted the everyday life of rural communities and criminalised what were customary transactions (Chatterji I999: 225-226). Domachi was cut off from a regional economy that had formerly been linked to the Mymensingh district. In I947, Mymensingh was located in Pakistan (East). Like other towns and villages at the time that were close to the new border, Domachi experienced significant population movements. Bengali-speaking Muslims left Domachi for Pakistan (East), while Garos, Hajongs, Dalu, Koch, Banai ('indigenous' communities) and Bengali Hindus from northern Mymensingh relocated to Domachi in 1947 and in the subsequent decades. In I97I, during the Liberation War of Bangladesh, 
the town was a transit destination for refugees fleeing the war. In I97I, the India and Pakistan (East) border became the India-Bangladesh border (Map 6.3). Within another four years, following the death of the founder president of Bangladesh, Domachi offered sanctuary to political dissidents known as Kader Bahini, who challenged the imposition of military rule in Bangladesh. Many Garos fearing conscription relocated from Bangladesh to the state of Meghalaya. ${ }^{6}$

The partition resulted in multiple displacements and relocations in the socially diverse agrarian frontier of what is today Northeast India and Bangladesh (Van Schendel 2005: 46-49; Bal 2007: I60-I7I). Meanwhile, the region that is known today as Northeast India (and comprised of seven states) was appended to India in I947 (Map 6.4). The ad-hoc partition boundary resulted in regions of Northeast India becoming a part of the new state of India, though being geographically and socially isolated from mainland India.

Though Bangladesh and India mutually agreed that that migration without passports would be considered illegal after 25 March I97I, this date remained inscribed in legal and official documents only. Kinship ties and cross-border marriages persisted, in Domachi as well as in towns such as Chandpur and Kalipur in Bangladesh. New families and citizens were created. ${ }^{7}$ Though passports are officially required, they are seldom used by borderland communities, especially those involved in trans-border trading and labouring.

Border markets in Domachi have temporary stalls and newly constructed permanent shops. The combination of makeshift stalls with plastic sheets, bamboo poles and concrete structures reflect Meghalaya's border policies. The state of Meghalaya persistently demands that the

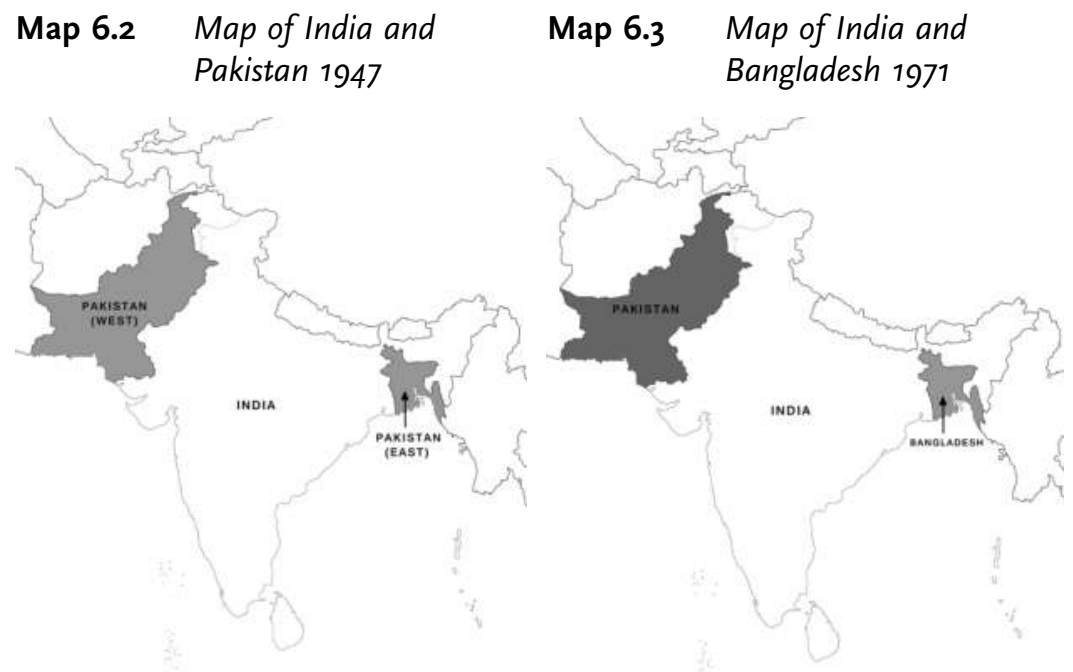


Map 6.4 Map of Northeast India

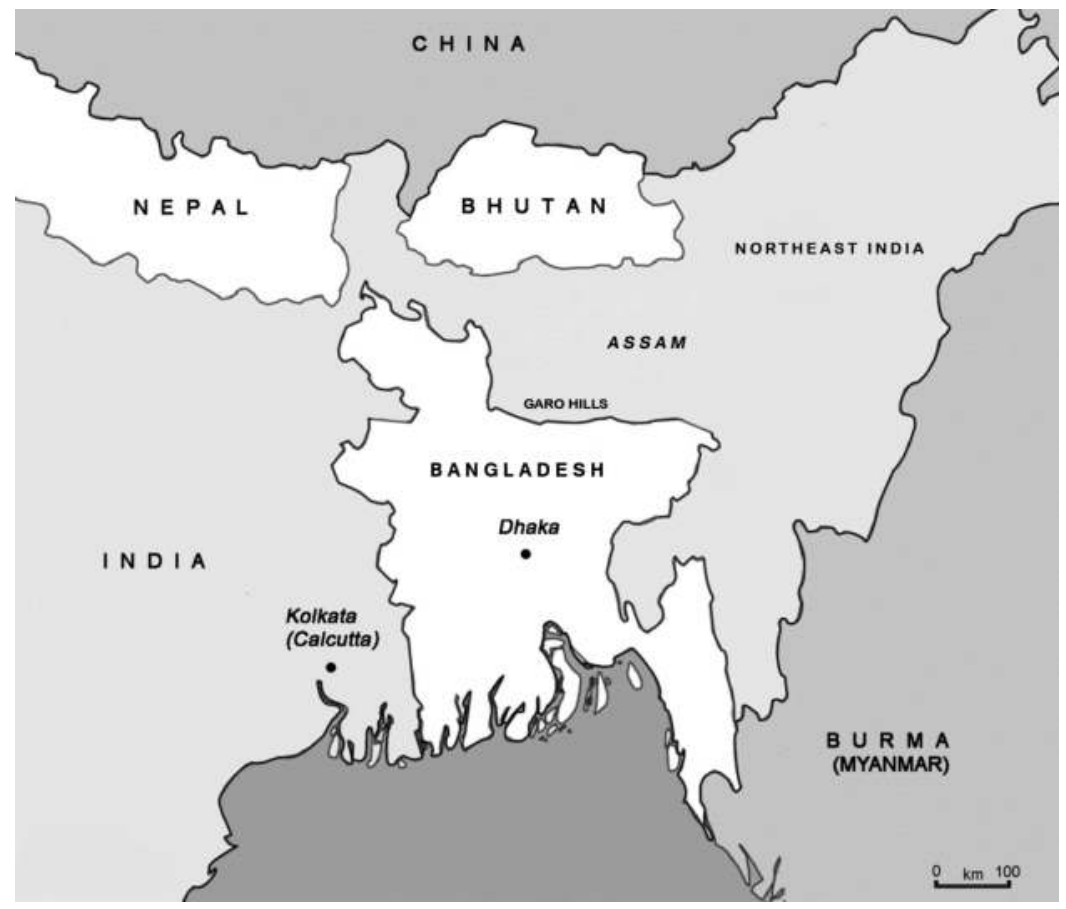

travel of traders and low-value commodities from Bangladesh up to \$50 per trader be allowed without passports and permits. ${ }^{8}$ Though only one experimental market was set up in July 20II, small-scale trade between border markets in Bangladesh and Meghalaya occurs without legalisation and is not prohibited. Furthermore, it hones women's entrepreneurial capacities. All traders rotate between various border markets in Meghalaya. Located at a distance of a few miles from each other and scattered on either side of the international boundary, these markets take place once or twice a week in sequence on specific days in a variety of set locations. Taken together, they ensure trans-border trading and labouring for a week.

The permanent shops in border markets in Domachi reflect Meghalaya's priority of developing border infrastructure and trade. India's border development policies have different implications for the state of Meghalaya. The central government of India funds the construction of border markets under schemes for border development. Unlike the state of Assam in Northeast India, which demands the speedy construction of India's border fence, the state government of Meghalaya halted construction work of the fence on grounds of illegal land 
acquisition. In 2006 , the state stopped the construction work of India's border fence in several parts where land acquisition for fence construction had been contested. There are multiple narratives that oppose the fence, including the central government seizing tribal land to build the fence, narratives of neglect and the contested meaning of Indian citizenship in Northeast India (McDuie-Ra, forthcoming). Even as these struggles over the acquisition of lands for border fencing persist, the construction of India's border fence gallops ahead in other areas where lands have been acquired for fence construction. Meghalaya expresses concerns about Bangladeshi 'infiltration'. Further, Meghalaya has set up 47 'infiltration check posts' manned by the police to deal with 'infiltration' from Bangladesh. The state also proposes to set up a new security battalion to deal with unauthorised migration from Bangladesh that would assist the Indian Border Security Forces that patrol the international boundary with Bangladesh. ${ }^{9}$

In Northeast India, the presence of unauthorised Bangladeshis is linked to questions of land loss and illegal participation in elections. In states of Northeast India - as in the rest of India - the image of the 'infiltrator and terrorist' is closely associated with being Bangladeshi, Muslim and male. The circulation of Muslim men of Bengali origin in the border regions of the state is aggressively policed and watched over, whether Indian or Bangladeshi. Bengali-speaking Muslims labourers are frequently inspected for identity cards, especially those engaged in mining and construction work. Muslim traders who travel without passports cross the Northeast India-Bangladesh border under conditions of guaranteed passage by bribing border guards or at risk of their lives. Furthermore, the migration of low-caste Hindu men from Bangladesh who desire to settle in Meghalaya and claim Indian citizenship has also come under increasing scrutiny.

A significant outcome of escalated militarisation in India has been the strengthening of community vigilance towards 'suspected foreigners'. Village defence committees, set up following the partition of India in I947 and dormant since the I970s, received new life with India's new border fence construction in 2006. In Domachi, the members of these vigilante groups proudly display their blue volunteer badges; they identify newcomers who seek to settle and acquire Indian citizenship and report them at once to the police as 'suspected foreigners'. Also, escalated patrolling has discouraged cross-border marriages. The migration of Garo men from Bangladesh who seek to be in India for marriage and residence (matrilocal) have declined.

However, when citizenship and settlement is not on the agenda, Bangladeshi goods and labourers are preferred in Domachi. Border guards remain embedded within the transnational and shared history of the region and the need for a docile workforce. Today, as a district 
headquarter and a border town, Domachi is a hub for town planning and border infrastructure development. Spatially, Domachi functions as an extended space - its needs and attractions for labour stretch far beyond its geographic contours. Domachi is better imagined by its proximity to Chandpur and Kalipur in Bangladesh. In such stretched zones, the circulation of permissible foreigners is as commonplace as the presence of citizens. ${ }^{\text {IO }}$ Thus, border infrastructure building overlaps mundane transnationality in Domachi. The somewhat truncated and yet trans-border geography of Domachi that accommodates on the one hand India's new border fence and on the other hand many kinds of trans-border flows, reflects the outcomes of strange partition boundaries. Escalated militarisation leaves small-scale commodity and labour flows relatively untouched. Such trading and labouring do not require immigration checkpoints or customs depots, as border outposts monitor travel, functioning as official ports of entry mediating travel without papers and permits.

\section{Bamboo Basket Trysts}

Bangladeshi Garo women traders who congregate at the Domachi market convey a sense of timelessness to trans-border trading: 'this trade has been eternal - for many generations'. The borderlands of Meghalaya and Bangladesh are built on older patterns of migration and trade connections, reflecting the connection between the hills, the foothills and the plains. ${ }^{\text {II }}$ Women traders posit that trading existed long before the international boundary was imposed in this region.

Garo women traders bypass the gaze of escalated militarisation at the India-Bangladesh border. They arrive in Domachi from the south (Bangladesh) after crossing the international boundary. Indian traders arrive from the north (Meghalaya, Northeast India). Both groups converge at the market. Tee shirts labelled with American flags, colourful leggings, striped brassieres, woven stoles, ornate melamine crockery, vegetables, edibles and soaps manufactured in Bangladesh lie next to piles of ginger, tubers and oranges grown in Meghalaya. All items find eager consumers in Domachi, which is fifty miles from the district headquarters.

Sorola, a Bangladeshi Garo trader in her thirties, is a part of the bamboo basket tryst. She occasionally wipes her child's sweaty forehead in the afternoon sun as it peeps in through the tin roofs of the grocery shops. She places a hand to partially cover her face from the sun as she speaks to me. Like other villagers who live in the borderland, life is tough, as she generally walks two miles between her house in Bangladesh and the market at Domachi. Although there is always 
Photo 6.1 The India-Bangladesh border: A Garo trader crossing the river boundary

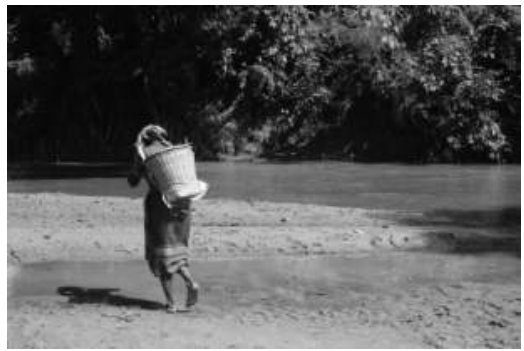

Photo 6.2 Garo traders at a border market

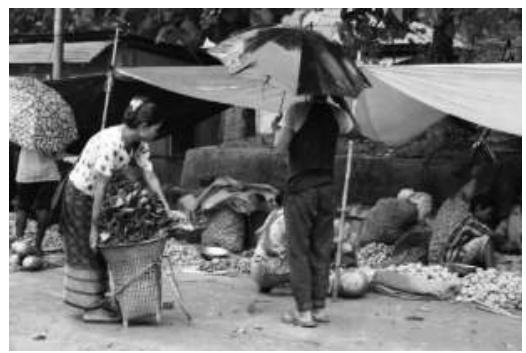

income, some days are better than others. Normally, traders like Sorola earn US\$ I per day, although earnings increase during festival season.

Although Bangladeshi Garo men's movement for daily wage labour is desired, their travel with commodities is not. Over the years, the role of Garo and other adivasi ('indigenous') men in subsistence trade have considerably declined. Garo men help women in carrying goods to the border. But they do not cross over with commodities. Since the region has been defined in the past and in the present as a refuge for rebel peasants, communist exiles and political activists, men are imagined to be political dissidents and alcohol smugglers. Protests about women's cross-border mobility and travel to border markets have also subsided. These protests were linked to cases of intermarriage among Garo women and Bengali men. Furthermore, the creation of Meghalaya in I972, a homeland for the Garos among others, had important implications for this border region and trans-border travel for the Garos.

Since demands for independent homelands and political struggles in Northeast India have led to the labelling of this region as a zone of political dissidence by the Indian state, men's border crossings with commodities are aggressively prohibited by the Border Guard Bangladesh and the Indian Border Security Forces. Their presence is threatening, and so are the commodities that they are imagined to be trading in arms and alcohol, both dealing with 'bad' substances that threaten national security. In Bangladesh, 'going to India' is still seen as a 'crime' when it comes to Bangladeshi Garo men, especially young men who are intercepted by Border Guard Bangladesh. Garo men are labelled as alcohol smugglers, carrying cheap alcohol from the state of Meghalaya to Bangladesh where, being an Islamic state, alcohol consumption is prohibited. 
Photo 6.3 Products displayed at a border market

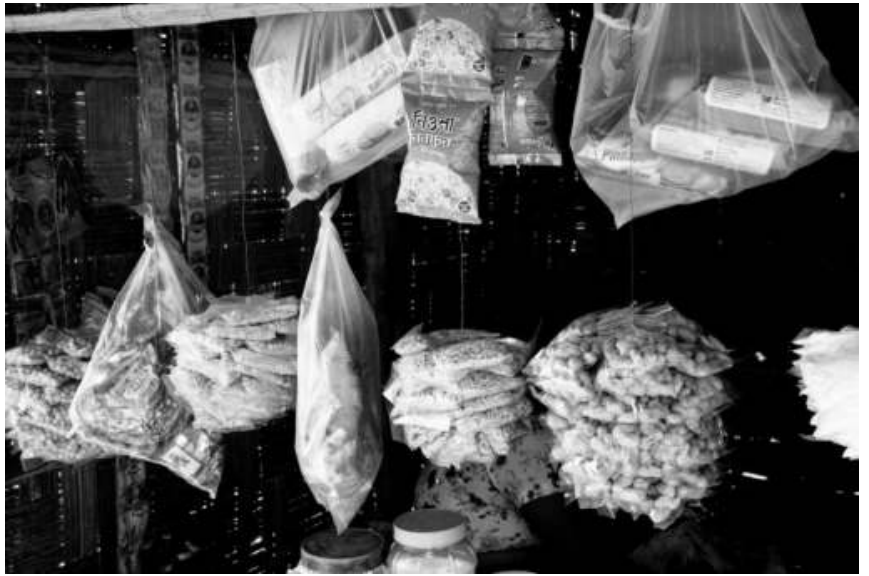

Photo 6.4 The border market at Domachi

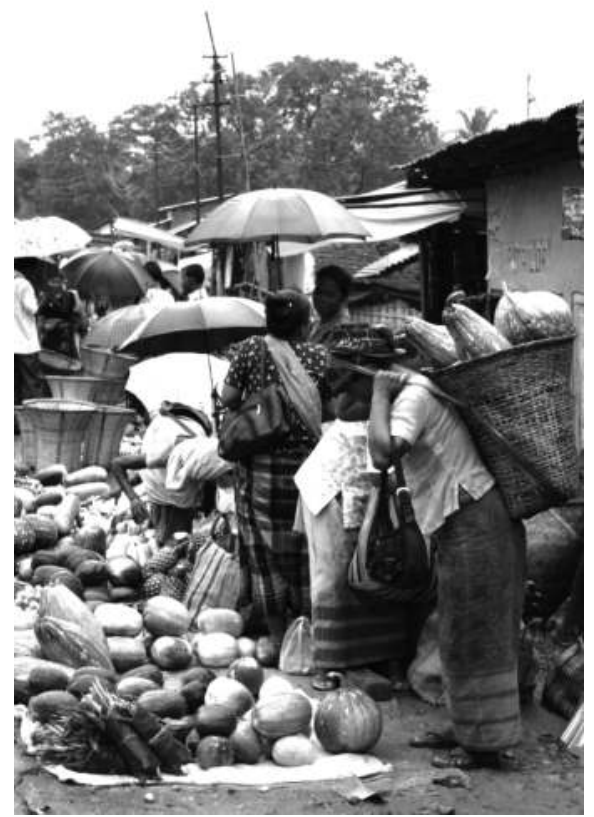


As contrasted, the routine passage of Bangladeshi women traders with bamboo baskets and small cloth pouches is as matter of fact as that of Indian Garo women traders. Bangladeshi women arrive every morning walking across the border and depart at dusk. Border outposts that are colloquially known as border camps function as immigration checkpoints, occasionally searching baskets and offering travel advice during high-security alerts. Because women are neither discouraged nor prohibited, when questioned about their passage from one country to another, women respond in annoyance that travel is always allowed, as they are not 'smugglers'. Travel for small-scale trading is socially sanctioned in the borderland. This is called kacha bebsha (perishables) and it is sharply distinguished from pakka bebsha (high value and often contraband) trading in drugs, arms, precious metals, etc. Border communities shun the latter, as it involves dealing with 'bad' substances. Border passages for subsistence trade are negotiated by politicians and priests with border outposts in India and Bangladesh.

During their afternoon break at tea stalls near border markets, Bangladeshi Garo women traders express their surprise at and even brush aside my questions about borders being dangerous. Traders emphasise that despite India's new fence and the 'gathering' of border guards (implying escalated patrolling), hardly anything has changed for women traders. The border is safe for women who are regular. Minoti, a Bangladeshi Garo trader, avers that 'no one will stop us, there is nothing to fear'. 'When no one does any harm, where is the need to fear?', most say. Monju, a young trader who travels with her son strapped to her back, remarks: 'the border guards look the other way when we cross, but there is nothing to fear'. A few others chip in: 'they sometimes check our bags and baskets, but no one has ever prevented us from trading'. Jonaki and Minoti, elderly traders in their sixties who trade in garments, assert: 'but why fear? We are Banglar manush.

Translated from Bengali, Banglar manush implies people from Bangladesh, but in this context the invocation is more specific to the regional and ethnic context. It indicates that Garos are able to travel across the foothill, hill and partly forested landscape between Bangladesh and Meghalaya. Banglar manush indicates the fluidity with which Garo women navigate the partly fenced Northeast IndiaBangladesh border. Therefore Banglar manush is not about emphasising difference and Bangladeshi nationality. Though only one experimental market was set up in July 20II (that permits travel without passports), small-scale trade between border markets in Bangladesh and Meghalaya occurs without legalisation and serves to hone women's entrepreneurial capacities. In Domachi, the inconsequential and unthreatening status of adivasi ('indigenous') women is critical in granting passage. Despite fences and border outposts neatly dotting the international boundary, 
the small-scale trade in border markets between Domachi, Chandpur and Kalipur flourishes. The circulation of women traders from Bangladesh to Domachi, without passports and permits, is as regular as the movement of border guards who stride through Domachi with guns swinging over their shoulders. With every change in border patrolling, new guards are inducted into an older history of movement along this borderland that does not challenge national sovereignty.

\section{Conditional Passage and Selective Deportations}

During the monsoons, the rushing waters of the river Singsong cause the small wooden bridges that connect Domachi to the district headquarters to collapse. This disrupts vehicular traffic. Buses and trucks of potatoes and cement fail to arrive in Domachi. In the local imagination of the borderlanders, the Singsong River, which is known as Surma in Bangladesh, breathes life into Domachi. The fast current of the river speeds up timber traffic from Northeast India to Bangladesh. Logs of wood line the national highway, and traders are seen guiding timber rafts in the river. As the water recedes in the winter, boats ferry oranges from India to Bangladesh. The backs of Bangladeshi labourers remain hunched throughout their journey, to maintain balance. Office workers in Bangladesh, who also use these ferries, glare disapprovingly at the labourers and oranges. Sometimes they irritatingly question their companions to verify if the oranges were indeed from India. India's new border fence unsettles old equations between India and Bangladesh as friendly neighbouring states. The fence is a marker for distinction, a spatial barrier to prevent Bangladeshis from travelling to India. It denigrates Bangladesh. Perennial flows of Indian goods in this region, such as sugar, kerosene and oranges, now meet with some disapproval, even in border villages of Bangladesh.

Despite spatial barriers, questions of access to borders are complicated. The use of borders as resources reflects both regimes of permissiveness and violence. Like Bangladeshi goods that arrive in Domachi, Bangladeshi workers are preferred to local workers in Domachi. Unlike lazy locals, who are seen as argumentative and demanding, the Bangladeshi migrant workforce is hardworking, unprotected by legislation, and docile. Their docility is prized, as more work gets done in an eight-hour day by paying US\$ 2, the uniform rate for all labourers for construction work. Like several others in Domachi, Mr. Sangma, an assistant engineer with the public works department, prefers to employ Bangladeshis for road construction and repair. Arriving near the border, his bright red car is at once surrounded by a few men. A damaged culvert needed repairing. Soon, six young Bangladeshi Garo men are 
recruited for four days of work. Leaning on his car, Mr. Sangma vouches for the sincerity of Bangladeshi labourers. The car always stood out in the almost non-existent vehicular traffic behind the Domachi market, appearing and disappearing on the border road.

The Domachi market acts as an employment hub for daily wage workers. All labourers congregate here and rush in when they see contractors and brokers. While migrant labour from other parts of India and Northeast India are registered with the local trade union at the Domachi market and the union protects their working conditions, Bangladeshi migrants remain unprotected by legislation. The trade union ignores the presence of these workers. However, Bangladeshis are not discouraged to seek work nor are they prevented from working in the marketplace. There is an agreed-upon division of labour among migrant workers at the marketplace. The task of loading and unloading goods is reserved only for members of the trade union.

Unlike the discounted passage of women traders, Bangladeshi daily wage workers need to purchase their border passage. The arrangements under which Bangladeshi Garo men have been allowed to seek employment in Domachi and elsewhere in Northeast India merit analysis. Bangladeshi labourers purchase border passage through labour bondage in Indian border outposts. Such arrangements are widely prevalent in the hill and foothill regions. Every Sunday, under the supervision of Indian border guards, groups of Bangladeshi labourers toil in outposts. They engage in physically demanding tasks such as clearing thickets, loading and unloading heavy goods and cleaning and sweeping the compound of outposts. By engaging in tasks that are deemed lowly, undignified, and not done by local Indian labourers, Bangladeshi Garo labourers are able to purchase a week of border passage. On their way back to Bangladesh, they gather and collect fuel wood for border outposts in Bangladesh. Thus, states exploit the docility of trans-border labourers and appropriates their labour in specific ways. Like questions of livelihood, the requirements of maintaining border outposts transcend national boundaries.

Though these regular travel arrangements entail the colonisation of labour and bodies of Bangladeshi adivasi men by Indian border guards, the leader of one such Bangladeshi labour group Khogen articulates these arrangements in a very matter of fact way as he rests and chews on betel leaves in the house of a relative in Domachi, Northeast India. That afternoon, a group of seven labourers had completed work at an Indian border outpost and were resting along with Khogen before their return to Bangladesh. These arrangements are not protested as abusive and violating human rights, they are seen as an exchange of labour for border passage. The bonded labour of men also exposes the conflating 
body politic at borders, with the male subjugation of female bodies as partial. Rather, in Domachi, male bodies bend, hunch and squat.

Along with the discounted passage of Bangladeshi women and the conditional and labour-dependent passage of men, there are occasional border traffic interceptions in Domachi. Unlike the circulation of permissible foreigners, mobility that falls outside regimes of permissiveness is violently intercepted. Large groups of Bangladeshi miners, who join Indians in coalmines scattered around Domachi, are intercepted and deported as they travel from their workstations in India to Bangladesh during their annual journey back. The excitement of reaching home, often once every year, adds urgency to their travel. The presence of Bangladeshi migrants in large numbers and unfamiliar faces in Domachi trying to navigate a partly fenced border leads to deportation. All of a sudden, their status as Bangladeshis and the lack of official authorisation to work in India becomes critical and threatening. These concerns guide the hurried deportations of Bangladeshi labourers. Bundled Indian currency strapped into bodies is confiscated and the data entered into registers. Most miners forego their yearly earnings. The sheer volume of seized Indian currency adds to the 'glamour' of deportations for Indian border guards. Although the coal miners are also Garos, these travellers are not cushioned by states, localities and trans-border arrangements.

Unlike passages mediated by discounts for women traders and purchase through free labour, seizures of Indian currency from large groups of Bangladeshi foreigners and their subsequent deportation reinforce India's official narrative of controlling 'infiltration' and 'smuggling' from Bangladesh. Selective deportations that often lead to detention and torture expose how violence is unexceptional to social life at borders. Border patrolling suddenly takes on a national colour. Official vigilance escalates on both side of the international boundary. India's new border fence becomes significant and the most obvious presence is of border guards patrolling the international boundary. Upholding the spirit of bilateral cooperation, Bangladesh intensifies border patrolling along the Domachi-Chandpur sector. Near Chandpur in Bangladesh, Christmas festivities become subdued for the families of miners who were detained in India. Long after sundown, when families had more or less given up hope of news that the miners would be handed over to the border-patrolling officers of Bangladesh, a relative of a deported coal miner cursed that the 'whole lot was foolish'. A Bangladeshi Garo woman in her fifties, she ran a rice canteen in the same coal mining area where the men worked. She had travelled without a passport just a day before this group was intercepted.

Even though India's new border fence may appear forbidding for those such as the coal miners, arrivals and departures persist in 
Domachi. Especially Garo women traders - imagined as a mass of 'indigenous' women and different from Hindu and Muslim women, wearing sarongs and striped shawls - are not prevented from trans-border trading. Unlike Bangladeshi Garo men, women traders are not seen to be devious or potential smugglers. They walk with gunny bags and bamboo baskets and carry children on their backs. They are also not subjected to forms of discipline or labour extraction. Unlike Bangladeshi Garo men, women do not toil for Indian border guards in outposts or carry back logs of wood for border outposts in Bangladesh. Women traders are seen as helpless, deprived and harmless and their trans-border commuting is unhindered, as poverty and childlikeness define their border crossings.

By the late afternoon, vehicular traffic dies down in Domachi. Slowly, shopkeepers shut their wooden shutters and lock up as women traders gather their belongings. Indian traders tie vegetables and seasonal fruits in bamboo baskets and walk back home. Bangladeshi traders rush to a small go-down behind the market and dump their plastic sheets. They rush out again, usually purchasing sugar, rice and kerosene oil, to be sold in Bangladesh, placing their belongings in bamboo baskets. Then they walk across the international boundary.

\section{Conclusion: Licit Bodies and Lethal Borders}

My engagement with traders, labourers and state agents in Domachi illustrate that legitimacies are produced when state and borderland vocabularies of transgression and permissiveness are coeval. State agents at borders discern some border crossings as benign and others as threatening. This kind of screening is not seen as compromising state sovereignty. Border outposts in India and Bangladesh, even those that are not mandated with official immigration functions, are better imagined as official ports of entry and exit. Mobility that contributes to a regional market economy, does not involve settlement and Indian citizenship or compromise goals of national security, remains permitted. I have argued before that the spectre of migration from Bangladesh haunts Northeast India and the Indian state, as it touches on questions of land use, displacement and electoral politics. These politically volatile agendas, therefore, remain relevant for border screenings in Domachi.

The circulation of foreign commodities and labour in Northeast India provokes engagements with the politics of space and consent as social conditions in borderlands. As unauthorised border crossings continue to be conflated predominantly with rights violations, and trans-border migration with political membership, an entire gamut of consensual regulatory practices remains underexposed. Therefore, Abraham and 
Van Schendel's (2005) formulation of the 'illegal but licit' is a very timely and apt reminder of the politics of consent, especially when new security regimes since $9 / \mathrm{II}$ and narrations of border violence eclipse other understandings of militarised borders. In the absence of labour migration frameworks that take into account the requirements of transborder daily wage labour, opportunities of access are critical. Militarised borders that are navigable address questions of sustenance in relatively deprived regions. People move from one part of the borderland to another for daily sustenance - border passages ensure small scale trading and daily wage labour. These passages provide sustenance in a region of fragmented agricultural lands, both between agricultural seasons and during lean agricultural seasons. Women, in particular, prefer to trade and travel with infants and young children rather than work as agricultural labourers.

The fluidity and relative safety with which women traders navigate the India-Bangladesh border, the labour extraction of daily wage workers, and the selective deportations broaden the scope of border violence and body politics at borders. Body politics in Domachi does not entail male subjugation of female bodies. Women's bodies are hurried, but not out of fear. Men's bodies bend and hunch in bondage once a week. The traffic of bamboo baskets at the India-Bangladesh borderland erodes the fleshy intimacy of body politics that normally draw on genres control and abjection to explain women's border crossings.

Precisely because such border crossings happen as if India's new fence and armed guards did not exist, they expose the limitations of thinking about women's migration only in terms of legal protectionism. I concur with Kapur's persuasive claim that women's transnational migration needs to be legalised and protected and with her astute observations on how stringent laws push women towards clandestine migration. But Kapur assumes, far too soon, that women are perennially excluded and unsafe as transnationals (2005: I09). Without disputing Kapur's position on the predicament of the postcolonial migrant, the alien and the refugee, this chapter has offered other constructions of gendered subjectivities in border crossings. Proponents of legal protectionism fail to take into account social, trans-regional and gendered identities that enable women to cross borders without passports and in relative safety. They also fail to account for the varied ways in which women are able to negotiate even highly militarised borders and use them as resources (see Pattadah \& Moors in this volume).

The bamboo basket trysts in Domachi show another face of an otherwise violent border. The circulation of Bangladeshi Garos in Domachi is inconspicuous and unthreatening to the new fence and escalated military presence. The moral outcries against women's bodily subjugation, the calls for resistance against rights violations and the claims of political 
membership are challenged in Domachi. At borders, the state apparatus is hardly a guarantor of rights or a protector of individual freedoms, but by screening and permitting benign passages, states partly address issues of deprivation. At the same time, it is also evident that border development in India is sustained by labour extraction and bondage. Furthermore, border outposts in India replenish and sustain themselves by consuming local and trans-border resources. Patterns of labour extraction and selective deportations at the India-Bangladesh borderlands show how discourses of terror and political dissidence remain gendered and directed at Bangladeshi men. The contrasting cases of small-scale traders, daily wage labourers and coal miners in Domachi expose that men's border crossings remain far more regimented and violent.

Licitness creates its own genre of violence. I argued that social legitimacies are tangled with questions of violence in complex ways, which Abraham and Van Schendel's (2005) 'illegal but licit' framework fails to adequately locate. In their formulation, states are projected as generating a very specific form of violence by labelling all unsanctioned transnational flows as politically subversive and criminal. The systems of regulation, through which borders are guarded and protected, often stand apart from official mandates, and take varied forms. Therefore, the importance that Abraham and Van Schendel give to the official/legal context and the gaps between state and social legitimacies is mitigated. The same border patrol that facilitates the mobility of women traders colonises the bodies of men and violently deports others. Furthermore, border violence is not protested by border communities lest opportunities of access to the border and livelihood cease. The trans-border mobility of Garo women reflects their dismissal as citizens of Bangladesh and as foreigners in India. Their lives continue to be transnational not just due to social overlaps and demands but because they are neither complete citizens nor threatening foreigners. Despite border militarisation, they continue to lead trans-border lives, as their location in the borderland is defined by their political insignificance.

The mobility of Bangladeshi Garos in a militarised border demonstrate how everyday comings and goings and violent expulsions co-exist and are accommodated within the social fabric of the borderland - what Samaddar calls the 'dynamics of the production of the natural' (I999: 20). Samaddar argues that the uncertainty and the frailty of borders emerge, as it situates itself on a hazy demarcation between the external and internal. Though borders are unconditional markers of the state system in South Asia, it is their uncertainty and frailty that unsettles state authority. The author advances that in border zones, transnational affiliations and the sheer struggle for survival override national affinities. The border then remains a permanently fragile phenomenon, 
and oscillations between the inside/outside and the citizen/alien generate and accommodate paradoxes (Samaddar 1999: 19-20).

Though borders and fences are planted to mark out people and places, they counter intuitively induce transnational spatial practices and propel regions and people to be more interconnected. Protecting and guarding national territory and disciplining border populations remain coloured by gender, ethnicity and religion. It is precisely the imagined transience of everyday border commuters and their actual permanence as silent and cheap contributors to transnational economies that make it a compelling arena for investigating border legitimacies and violence.

\section{Acknowledgements}

This work is part of the 'Illegal but Licit' research programme, which is financed by the Netherlands Organisation for Scientific Research (NWO). An early version of this paper was presented at the conference, 'Labour Migration and Trafficking: Policy Making at the Border' under the aegis of the ANRC (Australia Netherlands Research Collaboration) and CAPSTRANS (Centre for Asia-Pacific Social Transformation Studies at the University of Wollongong) Kuala Lumpur 2009. I thank the organisers and the participants for their comments and observations. Sapan Adnan, Itty Abraham, Sara Hossain, Rakesh Kumar, Atreyee Sen and Diana Wong's suggestions helped me rethink many aspects of this paper.

\section{Notes}

I Domachi is a fictitious name. The names of traders and workers in Domachi have been changed to protect their identity. The term adivasi is only partially translated in English as 'indigenous'. I place it within quotes. The Garos of Bangladesh use the word adivasi or upojati to refer to themselves. The Garos live in the Garo Hills region of Meghalaya, in Assam and West Bengal and northern Bangladesh. I prefer the term adivasi to the word 'tribe' which is vague, paternalistic and pejorative. Willem van Schendel's critique of the term 'tribe' in his discussion on the Chittagong Hill Tracks in Bangladesh is especially useful. The author shows how the term 'tribal' is invoked by post-colonial states in a sense of guardianship over 'primitive' people. See Willem van Schendel, "The Invention of the "Jummas": State Formation and Ethnicity in Southeastern Bangladesh,' Modern Asian Studies 26, no. I (1992). The Garos of Bangladesh are also a distinct group from the Garos of Meghalaya in Northeast India. See Ellen Bal 'They ask if we eat frogs: Garo ethnicity in Bangladesh' (ISEAS Publishing 2007:6). The term 'indigenous' that I use to roughly translate the word adivasi is also partial. The word is analytically ambiguous. It is also understood as a transnational implant in the Indian context. See Kaushik Ghosh, 'Between Global Flows and Local Dams: Indigenousness, Locality, and the Transnational Sphere in Jharkhand, India,' Cultural Anthropology 2I, no. 4 (2006). The meaning of the term 
'indigenous' also varies; it is used differentially by the Garos in India and Bangladesh. See Ellen Bal and Timour Claquin, '(Re) interpreting the indigenous peoples' discourse in different spaces: A case study of the Garos of India and Bangladesh', Asian Borderlands: Enclosure, Interaction and Transformation Chiang Mai, Thailand 5-7 November 20I0. I thank Ellen Bal for a very enriching discussion on these terms.

2 Sources in India estimate that there are to to 20 million Bangladeshis who reside in India without official authorisation. These numbers are rough estimates. Indian projections of unauthorised Bangladeshis often lack an empirical basis. The Home Ministry of India is cited by one report as estimating the number of "illegal Bangladeshis" as of December 200I at I2 million, residing in I7 Indian states. However, the report also states that in February 2009, the Home Ministry withdrew these data as "unreliable" and based on "mere hearsay." Daniel Naujoks "Emigration, Immigration, and Diaspora Relations in India," Migration Information Source: http:// www.migrationinformation.org/Profiles/display.cfm?ID=745\#I6 accessed on June I2, 20II. See also Walter Fernandes, "IMDT Act and Immigration in North-Eastern India," Economic and Political Weekly 40, no.30 (2005), 3238 and Hiranya K. Nath and Suresh Kr. Nath, "Illegal Migration into Assam: Magnitude, Causes, and Economic Consequences," SHSU Economics \& Intl. Business Working Paper No. Io-o6, December 20I0.

3 As Van Schendel points out, these communities were not mapped onto the two dominant religious classifications - Hindu and Muslim - that were the basis for the partition of the Indian subcontinent. Nor were these communities linguistically or culturally Bengali. The author exposes how non-Bengalis who were neither Hindus nor Muslims and people who use borders as resources have been marginal to partition scholarship in South Asia. Like Assam, Bengal and the Punjab, Northeast India experienced partition pangs and state-building. But partition unfolded in other ways in Northeast India, as the region represents a multi-ethnic mosaic blending - both topographically and socially - with other hill regions. See Van Schendel, The Bengal Borderland, 2005: 44-49.

4 Cross-border trading of this kind is common to many other parts of the Northeast India-Bangladesh border. For instance, such trade is common between the state of Mizoram in India and the Chittagong Hills Tracts of Bangladesh. There are also indications of Mizoram wanting to resume border trade with Bangladesh, like the state of Meghalaya. K. Anuraj 'Mizoram enjoys peace but clamours for progress', Sinlung July 27, 20II, accessed on Io November 20II, http://www.sinlung.com/20II/07/mizoramenjoys-peace-but-clamours-for.html

5 For the status of border fence construction in Northeast India, see Ministry of Home Affairs, Government of India, Annual Report 2009-20I0 (page 28-30), accessed 3 January 20II http://www.mha.nic.in/pdfs/AR(E)ogIo.pdf

6 Interview, K Rongdi, Lengura, Bangladesh, 3 January 2008.

7 Interviews: T. Nokrek, Mymensingh, January 2008; M. Toju, September 2007, and B. Momin September 2007, Meghalaya.

8 In July 20I0, India and Bangladesh signed a Memorandum of Understanding announcing that two border markets would open to small-scale trade of up to US\$ 50 without taxes and levies, and that travel without passports would be allowed within a fivekilometre radius on an experimental basis. Susanta Talukar, 'India, Bangladesh revive border haat', The Hindu, 23 July 20II, accessed Io August 20II, http://www.thehindu. com/news/article2288272.ece. Even as negotiations between India and Bangladesh on small-scale trading are being formalised in $201 \mathrm{I}$ on an experimental basis for more border markets, cross-border trading in Meghalaya has been routine. 
9 'Northeast CM's want border security tightened' August I8, 2009, Headlines India, Shillong, Agartala,http://headlinesindia.mapsofindia.com/defence-news/border-issues / northeast-cms-want-border-security-tightened-200Io.html.

Io On borderlands as expanded zones including two sides of an international boundary, see Michiel Baud and Willem van Schendel, 'Towards a comparative history of borderlands', in Journal of World History 8.2 (I997): 2II-242.

II Writing about the oldest segment of the border between what is today Meghalaya and Bangladesh, David Ludden states that even though waves of Hindu, Mughal and European colonisation of these frontiers imposed many borders, mobility was the defining feature of this region. Inhabited by many non-Bengali people, communities (like the Garos) with their matrilineal kinship were objects of curiosity and disdain for Hindus and Muslims. Despite European colonisation of the region that imposed settled cultivation and taxation as a way of sedentarising these communities, mobility was an essential social condition. David Ludden, 'Investing in Nature Around Sylhet: An Excursion into Geographical History', in Economic and Political Weekly 38, no. 48 (2003): 4-5, 49. 


\title{
7 Moving between Kerala and Dubai
}

\author{
Women Domestic Workers, State Actors and \\ the Misrecognition of Problems
}

Bindhulakshmi Pattadath and Annelies Moors

\section{Gender, Illegality and Licitness}

Mobility across international borders as well as state attempts to curtail this are facts of life for women such as Seena, Suja, Mariyam and Hussaiba $^{\mathrm{I}}$ who have worked for up to twenty years as foreign domestic workers in the Gulf. ${ }^{2}$ They are part and parcel of the large number of impoverished women from Kerala who leave their native lands and arrive in Dubai. Some had first worked elsewhere - Hussaiba in Saudi Arabia, Seena in Oman, and Mariyam in Oman, Bahrain and Ajman (another Emirate) - but at a certain moment they all had come to Dubai, where they joined the large contingent of foreign women who engage in domestic work. After some years of work, they would return to Kerala, but quite often they would then come to work in Dubai again. In the course of these multiple migrations, these foreign domestic workers have engaged at various moments in acts and activities that state agents would define as illegal. They leave India without a clearance, reside in the UAE with non-work visas, overstay their visa or abscond and then often have to make do without a passport and a residence permit. They engage with a network of agents in order to get duplicate passports and other fake documents. In some cases, they do so because they have no other options, yet some also go through illegal channels because they consider it easier and quicker than when they would go through state bureaucracies. ${ }^{3}$

There is a strong dissonance between debates on gender and illegality on the one hand and the narratives of these foreign domestic workers about their problems, fears and aspirations on the other. In academia and beyond, men tend to be defined as economic migrants, willing to pay smugglers considerable amounts of money in order to reach their desired destination, while women are mostly projected as unwilling, powerless victims of unscrupulous traffickers who intend to exploit them in the sex trade. ${ }^{4}$ Such images of men as economic actors and 
women as sexual victims are also commonly present in mediated debates on global human rights and are actively employed in efforts to push for the state regulation of poor women's migration. It is certainly true that there are cases of sexual exploitation of migrant women. However, such a unidimensional perspective jars against the needs and desires that Malayalee domestic workers themselves express. Many of them consider working in Dubai as the best option available, and their worst fear is to be prevented from returning to the Gulf.

This paper, then, focuses on how Malayalee domestic workers deal with state attempts to regulate their migration to and employment in Dubai. Their narratives point to the blurred boundaries of 'illegality' and 'legality', as they weave in and out of such statuses and engage in activities that some state officials would consider illegal, while others would not. One issue that needs to be addressed is the relation between (il)legality and (il)licitness. In general, as other contributions to this volume indicate, those involved in 'illegal activities' - including their families and the wider social circles they are a part of - often consider illegal activities as licit. These foreign domestic workers, however, have to deal with a situation that, at times, resembles the opposite; they are confronted with the fact that even when they adhere to state regulations, a wide range of actors may consider their work illicit. ${ }^{5}$ However, a focus on the acts - legal or illegal - in which these women are engaged is insufficient to understand the normative evaluations of these acts. The backgrounds of the persons involved must also be taken into consideration. The word 'background' depicts the complex trajectories women migrants undergo and their subjectivities based on the intersections of class, nationalities and the particularities of their labour in domestic work. Moreover, in order to gain a better sense of the meanings and effects of (il)legality and (il)licitness on the lives of Malayalee women domestic workers in Dubai, the perspectives of the women concerned need to be foregrounded. In this chapter, we first describe the rapidly changing relations between Kerala and Dubai. Next, we discuss how state actors in Kerala as well as Dubai have attempted to deal with the growing numbers of Malayalee domestic workers who come to work in Dubai. Our contribution foregrounds the narratives of Malayalee domestic workers in Dubai in order to understand their experiences of engaging in domestic work in Dubai. Analysing what this means in the context of their life stories reveals how state actors misrecognise their problems. Rather than helping to solve these, they may well put them in a more insecure position. 


\section{Kerala in the Gulf: The Transformation of a Longstanding Relationship}

The movement of people and goods between Kerala and Dubai has a long history. For centuries, the port of Dubai has attracted traders and immigrants from the coastal areas of Iran, Baluchistan and India, while Arab traders established themselves on the coast of Kerala, with persons and goods moving across the Arabian Sea. ${ }^{6}$ The I970s represented a substantial rupture in this pattern. The movement of people not only accelerated tremendously but also became far more uni-directional. In I97I, Dubai, together with six other Emirates, declared its independence as part of the United Arab Emirates, a federative state that was soon to become the world's second largest oil exporter. The enormous wealth acquired after the oil boom of I973 resulted in a huge increase in immigrant labour and a dramatic change in demographics. While in I968, local Arabs still made up 64 per cent of the population in what was to become the UAE, by 1975 nationals (citizens) had already become a minority of 36 per cent of the population, and by the I990s this had further decreased to less than 25 per cent. They formed an even smaller minority in the labour force, which by then was over 90 per cent expatriate. This demographic transformation was even more extreme in Dubai, a major trading hub in the region, with free trade zones, major investments in tourism and finances, and the development of high-tech media (Khalaf \& al-Kobaisi I999; McMurray 1999).

Amongst expatriates in the UAE, Indians are prominently present; estimates are that about 40 per cent of the migrant labour force in the UAE is Indian. They can be found at all levels of employment, including unskilled and semi-skilled workers, traders and shop owners, clerical workers and hospital staff, technicians and highly skilled professionals. Many of these Indian migrants in Dubai are from Kerala, which was rapidly becoming India's main labour-exporting state to the Gulf region. Whereas the population of Kerala is only 3.5 per cent of the total Indian population, in 1998 about 50 per cent of the migrants to the Gulf region came from there (amounting to I.4 million migrants). ${ }^{7}$ About ten per cent of these migrants are women who either accompany their husbands as dependents or move to the UAE on their own. ${ }^{8}$

Studies on migration to the Gulf have mainly focused on male migration (Prakash 1978, 1998, 2000; Zacharia, Prakash \& Irudaya Rajan 200I, 2002, 2004). For men, migrating to the Gulf not only means an escape from unemployment but is also a move toward full adulthood, defined by the combination of marriage, fatherhood and showing one's ability as a 'provider' (Osella \& Osella 2000). The work done on female migration is by and large limited to those in the position of 'Gulf wives', the women whose husbands are migrants to the Gulf (Gulati 
I993; Zacharia \& Irudaya Rajan 200I; Kurien 2002). Those studies that do deal with Malayalee women who migrate independently to the Gulf tend to focus on those employed in one particular profession - that of nursing. ${ }^{9}$ Whereas nursing was previously considered a lower status profession in which mainly Christian lower-middle-class women were engaged, the lucrative opportunities for employment in the Gulf have rapidly turned it into a far more attractive profession (Percot 2006).

Still, the UAE experienced not only an influx of female nurses but also, from the mid-I980s, a strong increase in foreign domestic workers. By I995, their numbers greatly escalated. ${ }^{\text {IO }}$ Although statistics are hard to come by, some have argued that I50,000 Emirati families employ between 250,000 and 350,000 domestics, while half of the 300,000 non-national families also employ domestic workers (Janardhan 2004). ${ }^{\text {II }}$ Malayalee women are prominently present amongst migrant domestic workers. Existing networks have not only facilitated the employment of Indian domestics in the households of Emirati families, a substantial number of Malayalee middle-class families also prefer Malayalee domestic workers. Whereas considerable research has been done on the international migration of Filipina and Sri Lankan domestic workers and on Indian domestic workers employed in India itself (e.g. the contributions of Tolen and Dickey in Adams \& Dickey 2000), no studies have as yet focused on Malayalee domestic workers in the Gulf. State agents, the media and the wider public have, however, noticed their presence.

\section{Controlling Mobility, Producing Illegality}

Illegal border crossings and residency turned into a matter of concern when the newly formed UAE started to develop laws of nationality, citizenship and residency. This became more pertinent when the UAE became a welfare state for its (very small number of) citizens. Throughout the years it has become very difficult, if not impossible, to gain UAE citizenship. This means that also Indian middle-class families who have spent decades of their lives in the UAE are not entitled to Emirati citizenship.

Most Indian workers hired after the oil boom are, however, contract workers employed on a temporary basis (often two years), with only those above a certain income level who are allowed to bring their family members or to change employers. They not only need a national sponsor - contracts are granted under the kafil system, with a national citizen (or a company) acting as the guarantor/sponsor for the worker but in addition, a host of middlemen are involved and take a cut (Willoughby 200I). Because of longstanding networks of kinship, trade 
and labour, many migrants from Kerala are employed in the informal sector, with many employers and managers of Keralite labour in Dubai hailing from Kerala (Kurien 2002).

Migrant domestic workers find themselves in a particularly vexed position with respect to legal systems. As other workers, they need a sponsor and are temporary contract workers. But because they are employed in the 'private household', they are not covered by the labour laws, and their employer - who is also their visa sponsor - is responsible for them and usually holds their passport (Sabban 2002: I8). If the employer decides to break the contract for whatever reason, their visa is cancelled and they are obliged to leave the country.

Over time, both the UAE and the Indian state have attempted to further control and regulate migration. Amongst UAE nationals, the tremendous dependency on foreign labour has created a general sense of being 'under threat'. As a result, the state has started developing disincentives for the employment of expatriate labour (in an attempt to 'Emiratize' the labour force) while simultaneously endeavouring to diversify the labour force in terms of its national origin (Sabban 2002, 2004). Indians are a major target of this policy, both because of the large numbers involved and because of their longstanding presence.

Whereas Emirati families, even those on welfare, consider the employment of foreign domestic workers not only acceptable but also a necessity, in the public discourse there are strong views about this form of employment (Moors, Jureidini, Özbay \& Sabban 2009). The women concerned are seen as the cause of children being insufficiently socialised as nationals in terms of such crucial markers of belonging as language and religion. At the same time, the state is caught in a dilemma, as it needs national women to join the labour force for its programmes of Emiratization, which further encourages the employment of foreign domestic workers to take care of their households and their children. Since 1996 , therefore, officials have started to implement a number of measures explicitly aimed at restricting the number of domestic workers amongst non-nationals. Emirate nationals are entitled to sponsor three domestic workers. There are no income requirements and the visa - valid for two years - is free; they only need to pay a refundable security deposit of 5,000 AED (US\$ I,362). Non-nationals, in contrast, can only employ one domestic worker per household and need to earn a minimum salary of 6,000 AED (US\$ I,634). They do not only have to pay the same security deposit as nationals, they must also pay an annual fee of 4,800 AED (US\$ 1,307 ) to the ministry of interior, and they are not allowed to employ a domestic of the same national origin (Sabban 2002: IO). Not surprisingly, this system has encouraged a highly profitable system of visa trading in the UAE, with nationals selling their visas to visa traders. 
At the same time, India has also made some attempts to regulate labour migration, focusing on particular categories of migrants. Debates in Kerala have mainly centred on the legitimacy of sending women abroad as domestic workers, with some state officials in favour of a complete ban. Arguments about banning migrant domestic workers are part of a nationalist political discourse that can be summarised as 'we do not want our women to serve Arabs'. Stories about the harassment and ill treatment of female domestic workers have certainly contributed to such an attitude favouring a complete ban. Weiner (I982) points out that the Indian government had already been considering a ban on the migration of single low-educated women to Kuwait when there were reports that domestics were being mistreated. In I983, an emigration clearance on the basis of level of education was introduced that was limited to specific - mainly Arab and Muslim-majority - countries. ${ }^{\text {I2 }}$ In the I990s, the Indian state started to restrict the migration of women as domestic workers to the Gulf because of reports about their bad treatment (Lim \& Oishi I996). In I999, there was a prohibition on housemaids migrating to Kuwait, but this was soon lifted again due to protests from Goanese and Malayalee families. ${ }^{\mathrm{I3}}$ In 2002, a minimum age of 30 years was introduced for domestic workers wanting to work in the Gulf countries, a move much applauded by the National Commission of Women, which wanted this measure extended to all countries (Varghese 2008). ${ }^{\mathrm{I}}$

\section{Domestic Workers Narrating (II)legality and (I)licitness}

What, then, are the effects of regulations such as the Indian age restriction for migrant domestic workers and the Emirati measures to discourage non-nationals from employing foreign domestic workers? In contrast to popular and academic writings that consider foreign domestic workers either as a threat to the integrity of the nation or as victims of unscrupulous men, the narratives of domestic workers present a different take; their experiences and the fears and desires they express point to other horizons. Although they follow diverse trajectories, certain common patterns become discernible.

Women who are already in Dubai on a dependent visa (usually through their husband) sometimes work as part-time domestics to earn an additional source of income. Whereas their employment is illegal and such work has a low status within the Indian community, the fact that they are living with their own families makes their work far less controversial than other forms of paid domestic work, legal or illegal. Take, for instance, the case of Leela, who migrated with her husband on a dependent visa to Dubai and works as a cook for a number of Indian families. 'I am not a domestic worker', she emphasised, 'I am just 
working because I get bored sitting at home. I only do cooking. If someone speaks harshly to me, I will leave that job immediately'. Leela clearly felt the urge to make sure it was understood that she did not need to do this kind of work. Yet, although such employment is considered far more licit than that of live-in domestics who have come by themselves to Dubai, it still is a grey zone of doubts and ambiguities, as becomes evident in the words she added: 'Nobody in my family knows my profession except for my husband. Had I told my children, they would not approve of it'.

Most Malayalee domestic workers, however, come to the Gulf on their own. Once there, they engage in a variety of employment relations and living arrangements. Many are live-in, while some 'live out'. They often work for one employer, but a smaller number of them work part-time for a number of households. Some work for Emirati, others for Indian families. In the course of their migration trajectory, they straddle a variety of positions of (il)legality, starting from the moment they leave India and enter the Emirates and including the time spent working and residing there, up to when they return back home (Moors \& De Regt 2008). To understand the 'moments that matter' and, more specifically, the ways in which illegality and illicitness structure their migratory trajectories, we need to turn to their narratives.

\section{Leaving India: The System of 'Pushing'}

The large majority of migrant domestic workers leave India without an emigration clearance. The term 'pushing' is used for such illegal border crossings, a method in operation in most of the airports in India. Amongst the women under thirty years of age, this is particularly prevalent. Their only other alternative would be to forge their birth certificate. 'Pushing' - a system of bypassing emigration clearance - is facilitated by officials at certain airports. Going through 'pushing' is also common amongst migrants who do not have an employment contract and travel with the help of illegal agents.

Suja, for instance, came to the UAE in the late I99os through an Indian agent. Although her Emirati sponsor had actually paid for her visa and ticket, she herself had to pay 29,000 INR (US\$ 6Io) to him as commission. The agent told her to come to Bombay airport, but initially things seemed to go very badly. 'I had sold my gold ornaments and given the money to the agent. But when I reached Bombay, the sponsor said that they did not want me anymore and the agent decided to send me back. I was upset. I had lost all my money. I told the agent that at least I should get my ornaments back. But then there was a call from the sponsor in Dubai to send me immediately. That was a great relief. 
About leaving India without a clearance, Suja explained, 'They sent me through 'pushing', using the Malayalam term çhavitti kayattuka. 'I stayed in Bombay for seven days; there were another two women and two families in our group'. When she arrived in Dubai, an agent was waiting there for her at the airport. 'He came to the airport to pick me up, holding a sign with my name. I went to the agent's office and he informed the family about my arrival'.

Mariyam had already worked in Oman and in Bahrain and had returned to Kerala but now needed to work in the Gulf again because her husband had become an alcoholic. She had given 30,000 Indian rupee (US\$ 630) to an agent who had promised to arrange everything. She also left the country without clearance. In her words:

I have seen many women like me when I came to the airport for boarding the flight. I had to stay there almost one week. After the agent had given bribes to the officers, they allowed us to go, when there was no checking at the airport; they call that 'pushing'. Many women were staying near the airport without any documents. They all come from very poor families.

While employers pay for the ticket, the visa costs and so on, local Indian agents often demand large amounts of money as commission from women who want to work in the Gulf, as both Suja and Mariyam mentioned. Such amounts are even higher when women travel with an (illegal) 'free visa', which is provided through large Emirati-Indian networks of visa traders. Seena, for instance, had first worked in Oman for four years. When she had become very tired of working there, she decided to quit and to return to Kerala, but she knew her return would only be temporary. In order to return to the Gulf, she then bought a private visa from an agent for 40,000 Indian rupee (US\$ 842).

\section{Moving Between Legality and Illegality in Dubai}

Having left India by illegal means, many of these women quickly acquired the status of 'legality' when they entered the UAE with a contract and other required documents. Many of them have been sponsored by nationals who employ them as live-in domestics in their own household, while others had been brought with a contract to Dubai by Indian middle-class families. In the latter case, they often receive a lower salary and less benefits due to the high costs involved in employing foreign domestic workers for non-nationals.

But the fact that they entered the country by legal means does not necessarily imply that they are able to hold on to this status of legality. 
Some of the women who entered the UAE legally later absconded because of bad treatment or very low wages. The moment they leave the household, they find themselves in a position of 'illegality'. Their position is further aggravated by the fact that employers often hold the passports of domestic workers; this means that they also end up without identification papers. Others abscond because they fear that their employer may want to end the contract, which would oblige them to leave the country immediately. And there are those who more actively opt for illegality, as they expect to do better when they are no longer tied to one household and have the possibility to work as a part-time, freelance domestic.

Absconding, then, is not always an indication of a position of subjugation. Although many women abscond because of extreme conditions of violence and exploitation, absconding also requires skills, resources and support networks. After Mariyam had arrived in the UAE, she first started to work in Ajman (one of the other Emirates) for an Emirati family, but as she said,

They did not pay me, so I left that house and tried to search for the agent. I could not trace him, but a family I knew here gave me refuge and put me in another Arab household. But they were poor people. I got my food and accommodation, but how long can one stay like that? I started meeting people and through the network I got a job in a Malayalee household. This family now pays me I,IOO AED [United Arab Emirates dirham]. ${ }^{15}$ I start working at 5:30 am and come back only by $6 \mathrm{pm}$.

Although she had found employment, Mariyam did not have her passport, which worried her a great deal:

When I ran away from the first employer, he gave my passport to the emigration department and also complained that I had stolen their things. Also, my visa is from Ajman, so I am staying in Dubai illegally. The run-away factor adds up to that. Because there are many charges against me, they will punish me and put me in jail. I will have to face it. As soon as I have a house of my own in Kerala, I will try to leave. I am worried, living without documents. There may be a raid and I might be caught then. If I am arrested now and sent back to Kerala, there is nothing in front of me other than death. I have nothing there to make me survive.

Hussaiba, who had first worked in Saudi Arabia, later had a visa arranged for the UAE through a family in Kerala where she worked as a 
domestic. Having arrived in Dubai, she first started to work for an Emirati family, but the workload was very heavy. Then a Malayalee man working in the neighbourhood who had noticed her plight helped her:

He told me that he could help me to get better employment somewhere else. At that time, my employers were thinking of cancelling my visa. I had no choice. Going home was not an option. One day I ran away. I started doing part-time domestic work in various households. I worked for three years without any documents. The man who befriended me gave me support throughout during this period.

Then Hussaiba was arrested; having neither a passport nor a visa, she was sent to a women's jail. She explains:

My boyfriend used to come and visit me in jail. After 45 days of jail term, I was allowed to go. It helped that he had arranged for an airplane ticket. When I reached Kerala, I stayed there only for 22 days and I came and landed in the same airport from where I was deported with a duplicate passport and started to work again.

When Seena came back to the UAE, she was employed by a large Egyptian family. She found it a very difficult job and finally decided to run away and to start working as a part-timer. However, she had once again not been able to take her passport and other documents. 'I found out that the sponsor had given a runaway complaint against me, but he did not hand over my passport at the emigration office'. As Seena wanted to go home, her first priority was to try to get her passport back. Rather than approaching the Indian consulate for help, Seena decided to negotiate with her former sponsor. 'If I go with an out-pass (emergency exit pass), it is difficult for me to come back. But if I can settle everything here, it is easy to come back with a renewed visa'. Seena managed to get her passport back from her earlier sponsor by paying 2000 United Arab Emirates dirham (US\$ 545). She did not need to pay a fine but instead paid a bribe to the officials concerned. 'You have to pay a bribe to each and every one. Then things will be OK. If I didn't pay them, they might have put me in jail since my visa is expired'.

In addition to women who enter the UAE with a contract, there are also those who come with a 'private visa' (a visa bought from an agent), which in itself is illegal. Still, some women prefer to come with a 'private visa' because then they are not obliged to work for their sponsor but free to work anywhere. Large networks of visa traders and middlemen are active in this burgeoning visa business. Often, nationals sell 
their free visa to these traders who, through middlemen, recruit women from Kerala to Dubai for sums of up to 150,000 Indian rupees (about US\$ 3,60o); moreover, they often also have to pay considerable sums of money when their visa needs to be renewed. In spite of this, many women sell off their property, if they have any, or take loans from local moneylenders in order to be able to get to the Gulf. Such indebtedness becomes yet another reason why they feel they cannot return home emptyhanded.

Suja luckily negotiated a direct arrangement with her sponsor. After working for four years for the family that had sponsored her originally, Suja had to leave to return to Kerala for an operation, where she stayed for one year. 'My former sponsor then agreed to sponsor my visa for a second time and to allow me to work for others,' she said, but she had to pay 3,500 United Arab Emirates dirham (US\$ 953) every two years for renewing it.

Both the women coming with a 'free visa' and the 'runaways' are a particularly attractive source of labour to Indian middle-class families who in this way can avoid the complicated process of bringing someone from abroad and do not need to pay the high non-national fees for employing a foreign domestic worker. Sometimes these domestics without legal status work as a live-in for one employer only. Many, however, prefer to work as live-out, often as part-timers for a range of families, including nationals. Working as a live-out gives them more bargaining power, they are able to make more money, and they have more freedom. But there are also serious drawbacks, especially the fact that these women then need to organise their own accommodation. They usually share bed spaces in villas, where they are exposed to raids by officials from the Criminal Investigation Department (CID) as well as harassment from the landlords. Renting such bed spaces is not only very expensive (at least 450 United Arab Emirates dirham or US\$ I22 a month), such villas also have a bad reputation.

Suja had been confronted with such problems. She had set out to work as a part-timer in a number of houses, but she did not really like it. She explains:

If you work part-time, you will earn more money. But there are lots of expenses also. You will have to find your own accommodation. You have to pay for electricity and water. You cannot save much money. You need to share a bed space with others, and you never know with what type of people you are mingling.

So she found herself an Indian family where she could live-in and work full-time. This was not an ideal situation either, but Suja managed to find her way. 
By contrast, Mariyam, although working for one family only, lived out and therefore needed to arrange accommodation herself. Explaining her living conditions, she said, 'For the bed space I am staying in, I have to pay 450 AED [United Arab Emirates dirham, or US\$ I22] a month. There are eight people in one room: three housemaids, three women working in a hair salon and another one in some office'. She was worried because raids by the CID and police were common in this area. Compared to Mariyam, Hussaiba found herself in a far better situation, not in the least because she had found a new, supportive husband. Having married her boyfriend, she had become quite successful working at a number of houses as a part-time live-out worker, earning 30 United Arab Emirates dirham an hour plus five more for transportation. As Hussaiba said, 'my hardship is almost over'.

\section{State Regulations, Acts and Actors}

As these narratives indicate, Malayalee domestics in Dubai are in multiple ways involved in illegal activities, and the boundaries between legality and illegality are indeed porous. This does not mean, however, that being in a position of illegality is inconsequential. The idea that illegal activities are often considered licit from the point of view of 'the people' (Abraham and Van Schendel 2005) too easily poses a dichotomy between state officials on the one hand and non-state agents on the other. Contextualising the narratives of migrant domestic workers within the wider field of women's employment brings to the fore that people's interpretation of acts - be it legal or illegal - strongly depends on the backgrounds of those engaged in these acts.

It is evident that state regulations produce conditions that make it attractive for a wide range of actors to engage in illegal activities. The Indian ban on domestics under thirty years of age leaves younger women no other option but to migrate through 'pushing'. The Emirati regulations differentiating between nationals and non-nationals make it highly attractive for the former to become involved in the visa trade and the latter to hire women who are already in the UAE. As Kodoth and Varghese elaborate (in this volume), the state's regulation of migrant domestic labour turns the issue into female sexual security and, as a result, one of morality. They note that this ideology of protection underpinned by the gendered conception of citizenship and sovereignty produces what they call 'controlled informality', generating a parallel economy based on the exploitation of the poorest segment of workers. This raises the question whether these regulations were ever intended to limit the number of Indian domestics in the Emirates or whether they are examples of 'symbolic regulations' that present a concerned Indian and 
Emirati public with the impression that the state is acting and taking their concerns seriously. The main point here, however, is that, even when regulations do not have the desired effects, they may well have unintended consequences. Defining migrant domestic workers as powerless victims of their Arab employers or of unscrupulous men who try to traffic them into the sex trade amplify media debates that already label these women as a category 'at risk'. As a result, rumours and doubts about the sexual morality of migrant domestic workers circulate more widely and become cemented in the ways in which they are perceived, also in their own social circle. When Mariyam eloquently expressed her strong opposition to any kind of government ban, she also felt the need to directly address the issue of sexual danger:

There are women living 'badly' here. Even if they get everything from their employers, they are not satisfied. They want to make more money and live a life without any values. The problem is that lots of poor women suffer because of that. Women like me come here to make money to survive and protect their families. But the government does not allow these women to come here because even if they make money in a decent way, they are still considered as bad. So they do not allow these women to come to the Gulf. That is really sad.

Hussaiba explained what she had done to counter the effects of such rumours and doubts that had affected even her relations with her son. 'My son is married by now and he has a child. I brought him here. He did not know what kind of work I was doing. Everybody in my family thought that I was making money through some bad means. Only after I brought him here did he realise that it is money earned with hard work'.

The projection of female domestic workers as victims of sexual and other forms of harassment has given their labour the stigma of illicitness. It is this stigma that they refer to time and again, such as when they weigh the advantages and disadvantages of staying in bed spaces. It is then ironic that many Indian domestics in the Emirates, and especially those with illegal status, do not work for Emirati families but are employed by their Indian middle-class compatriots.

It is evident that a host of actors are involved in a wide range of illegal activities to keep this system working. Foreign domestics can only engage in illegal activities because there are Emirate nationals who are willing to take part in the visa trade and function as their 'sponsor', Indians who supply fake passports and other documents, a host of shady agents who arrange for leaving the country illegally and residing in the UAE under false pretences, state officials who accept bribes, and 
employers who do not hesitate to employ women with an 'illegal' status. Yet, whereas these multiple parties are all involved in providing possibilities for poor Malayalee women to migrate to Dubai through illegal means, many of them simultaneously condemn them.

Looking at the wider field of women's employment, it has also become clear that state regulations are not only gendered but also highly biased in other respects. Women's work as domestics is not considered problematic as long as they work in India; it only becomes an issue of public debate and moral panic when women do the very same work abroad. ${ }^{16}$ This is then yet another case of women being seen as an embodiment of the nation, while men are considered the real citizens of the state. Their employment abroad transgresses not only the boundaries of conventional notions of femininity - which centre on morality, motherhood and sexuality - and of masculinity, with men as the maintainers and protectors of women, it also puts the Indian nation as risk, since the state is hardly able to protect these women when they are working in households in the Gulf. ${ }^{\text {I7 }}$

There is also a striking contrast in the normative notions about the Gulf migration of Malayalee domestics on the one hand, and of nurses on the other. As Percot (2006) points out, rather than being seen as a 'category at risk', Malayalee nurses are seen in their own communities as shining examples of upward social mobility, evident by the fact that they have become highly desired as marriage partners. The approach of both the media and the state has also been very different in the case of these nurses. Whereas domestics are an embarrassment and put the nation at risk, nurses are involved in 'branding India' in a highly positive way. The Indian media have started to compare these nurses with the computer workers from Bangalore as a source of foreign remittance, and the Indian state intends to compete with the Philippines as an 'exporter of nurses'.

\section{To End With: Misrecognised Problems}

These regulations have such negative effects because they are based on incorrect assumptions. As Kapur (2005) already argued, the law often considers women as 'victims' incapable of agentic power while failing to address the factors that compel women to opt for such 'unsafe' border crossings. The narratives of migrant domestic workers indicate that state actors misrecognise the very problems these women are facing and by doing so further contribute to their precarious living conditions. The assumption that these women move from communities where they are 'safe' to foreign lands where their lives are at risk stands in stark contrast to their everyday experiences. In spite of the positive reputation 
of Kerala as a state with high literacy rates for women, low fertility rates and other indicators of women's well-being, many of these women leave Kerala in order to survive.

Suja, for instance, who was married at eighteen, was abandoned by her husband two years later due to 'the dowry problem', as she said. Soon after their marriage, he had started to harass her by asking for more money as dowry. But Suja's family could not afford to pay more. As a result, she had suffered continuous violence from him; once he had even tried to kill her. It was poverty that brought her to the Gulf. In her words, 'My financial condition forced me to come here as a domestic worker, I had one daughter, and there was no income at home. My father had passed away. My mother is an old woman. Back in Kerala, I used to go for daily wage labour. That was not enough'.

Mariyam's family had become indebted when her second child turned out to have a heart condition; they spent lots of money for her treatment, but the girl did not survive. By then, her husband had stopped working and had started to drink. Because of the domestic violence she was facing and the pressures of the accumulated debts, Mariyam left home to seek employment elsewhere. She first worked in Muscat as a live-in for an Emirate family. Able to save money there, she sent 50,000 Indian rupee to her husband, asking him to repay the loan, but when she contacted him later she realised he had not paid off the loan but had spent the money on alcohol. After that, she stopped sending him money and instead sent it to her mother. 'Whatever little I saved while working in Muscat was used for building a house for my mother,' she said. 'She did not have a proper house. They were staying in a thatched hut and I rebuilt it into a proper house. Later I helped to rebuild my husband's house also'. But things did not change for the better, and his habit 'became worse day by day'. Again she found herself without a house of her own. Leaving her daughter in the care of her mother and sister, she decided to come back to the Gulf to work as a domestic.

But whereas Suja and Miriyam are still struggling, Seena and Hussaiba point to their accomplishments. For Seena, her situation improved significantly after she started to work in the Gulf. She emphasised that she was the breadwinner of the family, even if her husband was also working in Kerala. As she said,

My husband is not very clever, he works as a daily worker, and you cannot earn much that way. But after I worked here, I was able to buy a rubber estate and ornaments, I repaid all my loans, rebuilt the house and sent my children to good schools. Things are better here. You can never earn this much money if you stay in Kerala. 
Hussaiba had started from a more difficult situation and had a life with ups and downs but had by now also managed to become quite successful thanks to work in the Gulf:

I got married when I was just $\mathrm{I} 3$ years old. My husband left for Saudi Arabia when I was pregnant and came back after the child was born. He arranged a visa for me and took me to Saudi Arabia, while my child stayed with my mother. I was I5 years old then. We only returned from Saudi Arabia when my son was four years old.

Once back in Kerala, the savings were used to build a house. But then her husband decided to sell the house and took all her money and gold. 'He told me he wanted to get a private visa, but he left and did not return. I ended up having to pay the rent and there was no money. So I started working as a domestic in neighbouring houses. Then one of the families where I worked for arranged a UAE visa for me'. Hussaiba left her son again with her mother, and did not even tell her where she was going.

The narratives of many other women who travel to the Gulf as domestics indicate that they find themselves in a situation of great poverty and indebtedness. Often their husbands are not able to provide for them or have left them (sometimes marrying another woman without divorcing them). As a result, many domestics in Dubai had previously been forced to work in Kerala as local domestic workers, as daily labourers or as workers in tea and coffee plantations. Sometimes their husbands had also become severely abusive, often in combination with an addiction to alcohol; in one case, a woman explained how her own husband had attempted to sell her into prostitution. Some women themselves were married at a very young age, and dowry problems were also mentioned. Their families usually had not been able to support them either.

Because they often live in such insecure environments, the measures restricting their migration - which are ostensibly meant to protect them - may actually put them in greater jeopardy, as they are pushed into illegal acts, disabled from leaving a sometimes unbearable situation or doomed to put their reputation at risk. Whereas the state sets out to ban younger women from working in the Gulf, it does little to protect them from poverty and 'their own men'. Moreover, it is remarkable that in Kerala, women are not only at risk in their own homes but also in public spaces, with very little action taken against sexual exploitation locally. ${ }^{18}$ Hence, in spite of the Emirates' shaky reputation in the field of human rights, the greatest fear of these women is that they will not be able to go or return to Dubai. As Mariyam had said before, 'If I am 
arrested now and sent back to Kerala there is nothing in front of me other than death. I have nothing there to make me survive'. And Seena was furious about the age requirement, exclaiming: 'Who wants you here when you have become old? At a young age, we are taking responsibilities for families, getting married and having children. Then why can't we leave and work there?' Although foreign domestic workers suffer hardship and injustices in the Gulf, given their life trajectories it is understandable why Seena ended her narrative with: 'Please, don't write that all women suffer here. I did not suffer. I am happy with my life here'.

\section{Notes}

I Pseudonyms have been used to protect the privacy of the women concerned.

2 In addition to ethnographic fieldwork, Bindhulaksmi Pattadath conducted in-depth interviews with $6_{5}$ women in 2007 for six months in Dubai and for six months in Kerala. Although the four women whose narratives are referred to here should not be seen as representative, the themes they bring to the fore are central concerns that regularly came up in conversations with other Malayalee domestic workers.

3 This work is part of the 'Illegal but Licit' research programme, which is financed by the Netherlands Organisation for Scientific Research (NWO).

4 For a critique of this dichotomy, see Schrover et al. (2008).

5 As Hansen (I99I, 2000) has argued, although in many settings, household work is automatically seen as 'women's work', there is nothing 'natural' about women leaving their own families and children behind to take care of others.

6 In the first half of the twentieth century, an Indian souk emerged in Deira, now part of Dubai; by the I930s, immigrants already made up nearly 25 per cent of Dubai's 20,000-strong population, and in I94I an Indian association was already created there.

7 Christians and Muslims, both about 20 per cent of Kerala's population, are overrepresented amongst migrants (Percot 2006). The long history of interaction between Arabs and Mappila Muslims - in part descending from Arab traders - has been the impetus for the latter's migration (Kurien 2002).

8 According to Percot (2006: 42-43), over I50,000 women migrate. Her estimation is that 40,000 to 60,000 of them are nurses.

9 On Malayalee nurses in Italy, see Gallo (2005), and in the US, see George (2005).

Io This is part of a wider pattern of increased female migration to the Gulf. Whereas up until the I980s, the large majority of labour migrants to the Gulf consisted of men, by the late I980s the number of women migrating started to increase rapidly. Many of them were employed as domestic workers. By the late I990s, there were between I. 3 and I.5 million Asian women working in the Middle East. Whereas in the I970s, women formed about I5 per cent of the migrant labour force, in the mid-I990s almost 60 per cent of the Filipino migrant labour force was female, and women constituted approximately 80 per cent of the Sri Lankan and the Indonesian migrant labour force (Gamburd 2000: 35).

II Others have put the number even higher - at least equal to that of the national population (Sabban 2004).

I2 Emigrant workers intending to migrate to countries such as the UAE, Saudi Arabia, Qatar, Oman, Kuwait, Bahrain, Malaysia, Libya, Jordan, Yemen, Sudan, Brunei, 
Afghanistan, Indonesia, Syria, Lebanon and Thailand are required to get emigration clearance before their departure from the Protector of Emigrants (POE). Getting emigration clearance through the POE is a tedious procedure.

I3 There also was a ban imposed for male domestics, but that was lifted again in 2000 .

I4 Finally, in 2007 a number of other regulations were introduced: a direct contract between worker and employer (not through agent) is needed with a minimum wage of US\$400, and a pre-paid telephone and a bank guarantee of US\$2500 are to be provided. Very quickly, however, the minimum wage and the security deposit were again withdrawn.

I5 Most Malayalee domestic workers who are live-in earn no more than 600 United Arab Emirates dirham (US\$ $\left.{ }_{1} 6_{3}\right)$.

I6 This contrasts with the view of migrant domestic workers themselves, who prefer to work as domestics abroad rather than for local employers. In the Gulf, some also prefer to work for Emirati families rather than for Indians.

I7 Labour officers employed at embassies in the countries of employment often argue that they are afraid to complain too much about the treatment of domestic workers because they then run the risk that domestics from less demanding countries will replace their nationals. There are, however, clear differences in the ways in which states and their embassies deal with migrant domestic workers. The Philippines, for instance, is a country where migrant domestic workers are also considered 'economic heroes' and where the state is far more actively involved in protecting them.

I8 A verdict of the Kerala High Court in 2005 January acquitted all of the 35 accused in the Sooryanelli serial gang rape case. The Sooryanelli incident involved a minor girl who was held captive and sexually assaulted by a string of men for over 40 days. This incident highlighted the frightening reality of the organised sex racket in the state. 'Sooryanelli' stands for the many episodes of organised sex rackets that have been unearthed over the last decade. The other incidents of organised sexual crimes in Kerala include the Vithura 'case' (I996), in which a minor girl was sexually abused from October 1995 to July 1996. None of the guilty was punished. In the Pandalam 'case' (1997), a college girl was physically abused. There are many more stories of unaddressed cases of organised sex crimes against women in Kerala. The most recent ones added to this endless list are the Poovarani 'case' (2008) where a fourteen-year-old girl died after being sexually abused by an organised sex racket and Alappuzha (2008) where three girl students committed suicide in their classroom after being sexually abused and blackmailed. All these incidents were reduced to mere 'cases' in the sensibilities of modern Kerala, which is failing to address the everyday lived experiences of women. 


\title{
8 Emigration of Female Domestic Workers from Kerala
}

\author{
Gender, State Policy and the Politics of Movement
}

\author{
Praveena Kodoth and V.J. Varghese
}

In January 2006, at a workshop on Social Protection of Migrant Workers at the Centre for Development Studies (CDS) in Trivandrum, a senior scholar of international migration recommended a total ban on the movement of women domestic workers to the Gulf region, citing extremely harsh working conditions. This was in accordance with the strong sentiment at the workshop that the severe exploitation of women migrant domestic workers warranted measures to control their movement. Puzzled by this course of reasoning, a middle-aged woman - a teacher from a local college - pointed out that women emigrate as domestic workers because they need work with relatively better returns than is available at home and not because they expect a life of comfort in the host country. Why then should poor women be prevented from seeking work abroad? Responding to this, a trade union representative cited an International Labour Organization survey which, according to him, had found that over 60 per cent of women domestic workers in the Middle East experienced sexual abuse. Were these appropriate conditions for women to seek work in? The question virtually silenced middle-ground voices such as that of the teacher by turning the issue into one of female sexual security and, as a result, one of morality. The workshop had already encountered the thin dividing line between migration for domestic work and illegal recruitment and trafficking, an issue that had served to mobilise opinion in favour of controls. This restrictive perspective on women's mobility is underscored also by Pattadath and Moors' research (in Chapter 7).

Government of India's restrictions on the emigration of women in 'unskilled' categories such as domestic work are framed as measures intended to protect women from exploitation. State protectionism of women is held together by a social framework that constitutes marriage as the principal axis of a woman's identity. Marriage is expected to protect women, and mobility outside it (by single women or without the husband) is perceived as potentially transgressive. This protectionism is 
elaborated through gendered conceptions of citizenship and sovereignty and is implicated also in the approach adopted by an influential strand of scholarship on international migration from Kerala. ${ }^{\mathrm{I}}$ The exchange of views narrated earlier exemplifies the gender politics that is routinely played out in fora that inform policymaking, but the mode of validation of restrictions on the movement of women is crucial. For instance, the same senior scholar who made the extreme recommendation of prohibition revealed later that he was prompted to do so by firsthand observation of the working conditions of women in the Gulf region. Struggling for words to describe the nature of exploitation, he admitted that it was no different for male workers, and yet he did not think that there should be similar restrictions on them. The easy conflation of a problem of exploitation (sexuality being an important aspect) and a problem over movement in the case of women belies acknowledgement that women's mobility is constantly under the social scanner and takes us to unexamined assumptions that are at the core of patriarchy in the state.

The 'illegal but licit' (IBL) research agenda draws our attention to the difficulty in the social sciences to fully understand movement linked to a preoccupation with the state and its ways of seeing. Abraham and Van Schendel (2005) call for a shift towards a focus on the participants in international movement. As 'moving people are typically characterized in relation to fixed social formations', scholars of international movement have struggled to understand 'why people move', more often than not directing attention to the economic motivations underlying migration theories (Abraham \& Van Schendel 2005: IO-I2). They propose that 'movement by itself should not be seen as a primary marker of social distinction but needs to be relocated within an ensemble of social practices which are mobilized at different times for different purposes'. The key methodological move is a change in the analytic demands of the study of mobility, "moving away from questions of "why move" to how movement takes place and what meaning is attributed to movement, especially by those who are moving' (Abraham \& Van Schendel 2005: I3). This move is underpinned by a shift in focus from the domain of state-sponsored legality (the political) to that of the licit (the social), where participants in movement negotiate, strategise and generate meanings.

As state restrictions on women domestic workers have the benefit of social endorsement, it may seem surprising that the state has not been able to enforce restrictions effectively, with the restrictions serving to promote the use of informal/illegal channels of emigration. What prompts the state to espouse protectionism on the one hand and facilitate a permissive polity on the other? Intermediaries, including recruiting agents and government officials, profit from the use of informal/ 
illegal processes by prospective emigrants and hence they have an interest in rendering them more effective than formal processes established by the state. We argue that the gender politics around movement provides an enabling condition for both state restrictions and the burgeoning of informal/illegal processes. The gender norm as an expression of power relations is elaborated importantly through control over women's mobility/sexuality. In this context, protectionism by the state reflects its investment in the gender norm but also contributes to the production of a form of 'controlled informality' in the emigration process - i.e. a shadow institutional space that may be seen as deliberately sustained through legal restrictions and ambiguities or a fallout of them, but one that nevertheless animates the emigration process and enables poor women to aspire to work opportunities that are difficult to access through legal means. Thus, the social and the political, the legal and the licit, coalesce in substantial ways to constitute the gender problematic in the context of emigration.

Emigrant women domestic workers from Kerala confront the dilemma of pursing a livelihood in defiance of protectionism - i.e. one that presumes mobility and compromises the gender norm - but their resistance and agency are directed substantially towards achieving the means to conform to the gender norm. In this context, it is imperative to spell out the challenge of addressing the dominant gendering of social class. The existing scholarship on migration from Kerala has not risen to the challenge, sharing as it does some of the assumptions of protectionism towards women. Framed until the late I990s by demographic and developmental perspectives, this scholarship has sought to direct state policy. ${ }^{2}$ Cutting across disciplinary orientations and perspectives, narratives on international migration from Kerala tend to prefix the category of migrant as essentially prosperous, overlooking questions of subalternity. Women appear foremost as wives of migrants who are transformed through a process of painful separation into industrious managers of family fortunes (Gulati I993: Zachariah, Mathew \& Rajan 2003). ${ }^{3}$ Formal estimates with respect to women domestic workers are lacking, even though informal efforts suggest a concentration of women workers in the segment (see Shah I994, 2004; Pattadath 2009; Esim \& Smith 2004). ${ }^{4}$ Because of the overwhelming male domination of the process, the choice of high-intensity migration areas for surveys is likely to underestimate women's migration. ${ }^{5}$ For instance, we found concentrations of emigrant domestic workers in the coastal stretch, which are more prone to poverty than the midlands (see also Pattadath 2009; Saradamoni i994).

This paper is in three parts. The following section seeks to historicise government policy on emigration and focuses on its deployment of gender to control women. Section three engages with the gendered 
meanings of movement that underpin protectionism and shape gendered conceptions of citizenship and sovereignty.

\section{Protection by Exception: Constituting State Policy}

Government attention was drawn to emigration when its economic importance became evident with the Gulf oil boom in the I970s. Since then, it has been involved increasingly, at the central and state levels, in promoting the process and developing networks to support it. ${ }^{6}$ Current policy restrictions on women derive from the Emigration Act of I983 which enables the Indian government to subject women to special protection/scrutiny, and administrative measures taken by the state from time to time through government orders, which give specific form to the protection/restrictions. The Act of $\mathrm{I}_{983}$ is administered by the Protector General of Emigrants (PGE) through eight field offices, known as Protector of Emigrants (POE), across the country that regulate overseas recruitment practices and grant emigration clearance. The Act does not exempt any citizen from getting emigration clearance, ${ }^{7}$ but it is administered by a logic of 'protection by exception', which bifurcates the status of citizenship, distinguishing between those who do not require an emigration check (emigration check not required, or ECNR) i.e. those who are technically qualified, specially skilled or possess a minimum specified level of education - and those who fall below a specified educational level, currently Class so, thereby requiring an emigration check (emigration check required, or ECR). Though the legal framework generates two classes of citizens through a promise of protection, the emigration clearance system offers nothing substantial to the ECR category. It turns out to be a document verification exercise which, in the absence of mechanisms to test the validity of documents, relies on the 'common sense and experience' of the POE (Rajan, Varghese \& Jayakumar 2009). ${ }^{8}$

Of late, the government has realised that the institutional framework sustained by the Emigration Act of 1983 is ineffective and lacks coherent legal, administrative and policy structures necessary to implement it. ${ }^{9}$ But there is no acknowledgement that the existing framework discriminates against 'low-skilled' emigrants from the country in general and 'low-skilled' women migrants in particular. The Government of India not only maintains a prohibition on women under 30 years of age from seeking employment in the ECR category; in the recent past (since 2008) it has also made efforts to enforce the age requirement through a series of advertisements in the print and visual media warning the public that it is dangerous to disregard the age requirement. The Ministry of Overseas Indian Affairs (MOIA) maintains that the 
restriction on women is based on the recommendation of the National Women's Commission, a government body set up with a mandate of protecting and promoting the interests of women, and is to "prevent exploitation of Indian nationals' ${ }^{\text {Io }}$ However, while the Ministry of Labour set the 30-year minimum age limit only for housemaids in the Gulf countries back in July 2002, ${ }^{\text {II }}$ the intervention of the National Commission for Women extended it in 2003 to all foreign countries. ${ }^{\text {I2 }}$ The effort here to 'prevent exploitation of Indian nationals' by prohibiting the movement of only specific categories of women - single, uneducated domestic workers - suggests that citizenship and sovereignty are expressed in a gendered idiom. The assertion of control over space through legal measures restricting women's movement reflects cultural values and differentiates them from men as gendered citizens.

The rationale underlying the current regime of protection/discrimination in government policy has roots in the colonial era. The passport of colonial India, which offered its holder the protection of the British Crown, was available to only a privileged few; it was an official attestation of civility open to men of means or of 'education and respectability' (Mongia I999; Singha 2006; Lake \& Reynolds 2008). The emigration regime devised for indentured migration was more at the service of the empire, and it bore an uncanny resemblance to the regime currently in place. The colonial office of the 'Protector of Emigrants' was in charge of determining the eligibility of coolies to emigrate based on the production of documents, especially the 'contracts on free will' or the 'coolie agreement'. ${ }^{13}$ It was 'to safeguard the rights of the ignorant, defenceless natives against illegal recruitment, to grant certificates of embarkation, and to see that all rules and laws governing the embarkation of transports were observed' (Erickson I934). Though it was expected to exercise a degree of control over recruitment practices, it had effectively little control (Lal 2006). '[I]t was not unusual that a trustworthy emigration agent [appointed by the labour-receiving country/colony to supervise the recruitment of natives as required by the colonial Indian government] to serve also as protector of emigrants'! (Erickson I934). Further, the 'coolie agreement' did not ensure protection due to the vagueness of the local laws in the destination countries; but the documentation served disciplinary purposes - binding the coolie to a five-year contract with one plantation owner and to stagnant wages - and made breaches of contract a criminal offence (Singha 2006). Subsequently, in response to the growing demand from the nationalist elite in India for nationalisation of labour and for the protection of unskilled emigrant coolies, the government attempted to stop the outward labour flows (Singha 2006). Calls to prevent the movement of Indians with 'hard hands, healthy bodies, ample chests and muscular limbs' animated the 
context that shaped the Emigration Act of 1922, the Passport Rules of I9I7 and the Passport Act of I920 (Singha 2006; Metcalf 2007). ${ }^{\text {I4 }}$

The gender-related discourses and practices of the colonial era find strong resonance today. Indentured labour migration from colonial India not only involved significant numbers of women but also witnessed not-so-successful efforts to regulate the sex ratio of migrants. The colonial government, though reluctant initially, encouraged indentured women's emigration through measures like a quota rule and rewards to recruiting agents for female emigrants (Mohapatra I995; Shameem I998). Measures promoting female migration - mainly at the behest of planters and the governments in the receiving locations coincided with a colonial discourse that portrayed women emigrants as 'low' in caste and in character (Mohapatra I995). Colonial administrators, planters and missionaries shared the position that 'respectable' women and single women of the 'honest and decent class' would be reluctant to emigrate (Shameem I998). This brought to the fore family migration as a moral strategy for the colonies endangered 'by the scarcity of honest women and want of family life' (Sen 2004). The nationalist discourse also shared this perspective on individual women migrants, suggesting that the indenture system enslaved men, made women prostitutes and destroyed the family and brought shame to Indians as a nation (Mohapatra I995).

Since 1947, emigration to the West and the early streams of migrations to the Middle East occurred with little regulatory attention from the newly formed Indian state but broadly within the framework of the Emigration Act of I922. Throughout the I980s and I990s, workers were moving without formal contracts and valid visas (Nair I998: 274). The rapid rise in emigration in the I980s was facilitated by ECR 'suspensions' obtained from the POE, making it legal to emigrate for work on visit visas (Nair I998: 274). ${ }^{\text {I5 }}$ The movement across international borders portends a loss of control over people - the everyday sense in which state control over territory is expressed - and is therefore resented by states (Abraham \& Van Schendel 2005: I4), but the Indian state has been remarkably reluctant to assert control. The Emigration Act of I9 $_{3}$ - brought in at the behest of the Supreme Court of India filled the gap created when the Union Government suspended the operative part of the earlier legislation so as to remove barriers against the emigration of unskilled workers (Nair I998: 273; Weiner 2007: I7I). With the economic stakes running high, the Indian government is also 'willing to tolerate conditions for Indians in the Gulf that it would not tolerate for its citizens elsewhere and its interventions on their behalf are likely to be in a subdued and less public fashion' (Weiner 2007: I43). The Indian government has intervened when there have been threats of repatriation. In I980, when 60 illegal immigrants expelled 
from the UAE arrived in Kerala, an alarmed Chief Minister, fearing a deluge of returnees, urged the Indian government to intervene. Subsequently, an Indian delegation was sent to the Gulf and, as it turned out, the number of Indians repatriated was small (Wiener 2007: I35, I7I). ${ }^{\text {I6 }}$

The Indian government has imposed restrictions on the movement of women workers on several occasions. When it prohibited the movement of single, uneducated women to Kuwait in the I980s following reports that domestic workers were being mistreated there, it faced protests 'from Goanese and Malayalee families', and 'Indian officials quietly permitted resumption of the migration' (Weiner 2007, emphasis added). Since the late I990s, there has been a more targeted effort to restrict this category of workers (Varghese 2008). In I999, the government banned the deployment of Indian workers as housemaids or male domestics in Kuwait, citing the post-war turmoil in Kuwait and the resultant harassment of foreign workers, especially those working in the domestic sector. ${ }^{\mathrm{I}}$ While the Ministry of Labour went on to lift the ban on male domestics subject to the attestation of documents by the Indian embassy in Kuwait, it made 'no change in the decision regarding the deployment of housemaids in Kuwait'. ${ }^{\text {8 }}$ Through a subsequent order the Ministry reiterated its decision, citing violations that had come to its notice. ${ }^{\text {I9 }}$ The age requirement of 30 years was put into place following this. Notably, such 'protection' positions emigrant women domestic workers as outliers both among the low-skilled emigrants and among women emigrants and illustrates the working of governmentality or the exercise of power through seemingly benevolent institutions (Foucault I99I).

The Ministry of Overseas Indian Affairs (MOIA) came into being in 2004, and in one of its first orders with respect to women workers, it lifted the prescribed minimum age criterion for all household service workers in the case of ECNR countries, permitting the relaxation of the rule with the approval of the Joint Secretary in deserving cases. ${ }^{20}$ However, it was forced to make a hasty retreat seventeen days later, when it directed all the POEs that 'women below the age of 30 years may not be granted emigration clearance, who seek any kind of employment including employment as housemaids, domestic workers, hair dressers, beauticians, dancers, stage artists, labourers, general workers, etc. in any foreign country'. ${ }^{2 \mathrm{I}}$ Its next move reiterated that, in the interests of women and for their protection, the age requirement of 30 years was mandatory in respect of all women emigrating on ECR passports, irrespective of the nature/category of employment. ${ }^{22}$ The order made it mandatory for prospective women emigrants to produce a direct employment contract between the worker and the employer which provided not only a minimum monthly wage of US\$ 400 but also a 
pre-paid mobile facility to the worker. Further, every foreign employer recruiting a female Indian emigrant is required to deposit a security of US\$ 2,500 in the form of a bank guarantee with the Indian Mission concerned. The POE may seek a copy of the bank guarantee duly attested by the Indian Mission before granting emigration clearance. Faced with stiff opposition from all stakeholders soon after, the Ministry withdrew its order on the minimum wage and the security deposit, which is seen as most unrealistic by many in the prevailing conditions. ${ }^{23}$

The repeated instances of the state stepping back from extreme forms of restriction on women workers and from the removal of restrictions altogether suggest that state intervention bolstered by social regulation has served to produce a form of 'controlled informality' in the emigration process that promotes the use of 'informal', largely unauthorised agents and procedures and indirect routes of acquiring clearance. The space for the manipulation of prescribed legal methods is produced systematically in the interests of people other than the prospective migrant - the unauthorised agents and the people in government who profit from it. ${ }^{24}$ Controlled informality renders informal processes more effective than formal processes established by the state, thereby attracting even those aspirants who may have the necessary qualifications or documentation. It facilitates a parallel economy by making way for services that replicate that of the polity. The parallel space is animated by agents with an extensive network across India and the Middle East who act, necessarily, with support from government officials. It enables the provision of several kinds of services. Where the applicants do not have the required qualifications/documentation, agents organise emigration clearance in association with officials at the POE and organise 'pushing' - i.e. sending women workers through without the requisite clearance, with support from officials at the airports. ${ }^{25}$ Agents take recourse to the 'Kasargod embassy', an operational network that 'produces' documents in place of those provided by the Indian state. ${ }^{26}$ Runaway female domestic workers in the UAE whose documents are in the possession of their former employers ${ }^{27}$ or others in search of documents are routinely referred to the Kasargod embassy, but their acquaintance with it is limited to an agent. $^{28}$ In the Gulf States, this network is engaged in establishing contact with poor women workers, enabling them to run away from demanding employers and providing support to find alternative employment and accommodation (Pattadath 2009: I76). ${ }^{29}$ Not surprisingly, female domestic workers from Kerala evince greater faith in these networks as being more approachable, friendly and supportive than the government mechanism. But also recruiting agents with some reputation at stake tend to withdraw from recruiting unskilled women for overseas jobs - they consider it an 'indecent' segment that could be 
touched only 'at the cost of our reputation'. ${ }^{30}$ In this context, controlled informality is a liminal condition that neutralises a stricter formalinformal dualism and gives space for fluid practices within a seemingly definite structure. The dilemma/ease of simultaneity as represented by controlled informality is either something conceded by institutional gaps or something negotiated by concerned stakeholders to serve their interests.

\section{Gender and the Politics of Movement}

In Kerala, the notion of economic mobility is deeply interwoven with the notion of spatial mobility such that the latter is a precondition for achieving the former; but strikingly, groups like low-skilled women emigrants are not present in such a sub-national common sense. The gender norm shapes the boundaries of what is socially acceptable for women and has fed into the state's and scholarly positions on international migration. Normative constructions of womanhood in Kerala are bound by restrictions on mobility. Imbued with gendered meaning, literally and metaphorically, movement is said to be arrested when a woman fails to get married - ninnu poyi or erunu poyi are local usages that mean 'to come to a standstill'. Marriage not only allows a woman to move ahead in life substantively - i.e. to achieve the positions of wife and mother, the principal identities she is socialised for - it also decrees access to a greater degree of physical mobility than she may previously have had. Thus, a woman who has failed to enter into a marriage is viewed as 'weighing down the house' through her immobility - pura niranhu nilkkuka.

Marriage is expected to protect women and to 'secure' their movement and hence is the social framework within which women are expected to pursue their livelihoods. Only one of several emigrant domestic workers featured in Pattadath and Moors (the previous chapter) is abroad with her husband on a dependent visa. And it is notable that even when she acknowledges the stigma associated with domestic work, she emphasises her difference from other domestic workers in terms of having an exit option and is therefore, it would seem, not susceptible to the murky deals that could come with the job. In fact, quite consistently, the narratives of domestic workers present the failure of marriage - through a breakdown or the husband's failure to provide for the family - and consequent poverty as the compelling reason for migration.

The prohibition or special 'protection' accorded to women below 30 years of age assumes that they are more prone to material, especially sexual, exploitation than women over 30 years of age or men of the 
same age group. By the time they are 30 years old, women in Kerala/ India are more likely than not to be married. As young men are not subject to similar concerns, and as there have been instances of single, uneducated women being barred from emigration for work, the underlying tension seems to emerge from the social priority accorded to the protection of the sexuality of young, unmarried women. As there is nothing to suggest that older women are free from exploitation, sexual abuse or sexual desire, do we then understand from this that marriage is expected to endow women with a level of social maturity and ensure that they observe existing standards of morality?

To probe how the gendered meanings associated with movement determine the position of emigrant women domestic workers, we discuss the experience of two low-status segments of women migrants - emigrant nurses, who enjoy a relatively higher status than domestic workers, and out-migrant fish-processing workers who are positioned at a similar level as, or worse than, domestic workers. In the case of women, low-status jobs - especially menial jobs that entail proximity to men and physical contact with them - carry a stigma. Despite demonstrating good economic prospects, nursing remains a choice undertaken under economic compulsion and social pressure to tap financial returns, and girls from well-off families are likely to be actively discouraged from taking it up (Nair \& Healy 2008; George 2000). Yet, there are no stateimposed restrictions on the emigration of nurses. On the contrary, as we elaborate later, there has been considerable investment in their training in ways that enable nurses to garner emigrant jobs.

The manner in which sexual morality inflects the discourse on Malayalee nurses is reminiscent of colonial discourses. Young emigrant nurses 'who live alone abroad' are castigated as 'easy women' (Percot 2006: 166). Nurses in turn associate the stigma on their profession with the nature of work it involves, and they shun many of the tasks of cleaning that are part of care work (Nair \& Healy 2008: I8). 'Twenty years ago, there was no respect for nurses. They used to say we were no more than servants. People were gossiping because we have to touch men in our job and they used to give us a bad reputation' (nurse cited in Percot 2006a: I53). The social position of emigrant nurses has been leveraged by their worth on the marriage market, linked to the opportunities it offers for the emigration of men. Matrimonial advertisements in newspapers and internet sites indicate their preference for nurses: 'nurse wanted' or 'nurse working in the Gulf will be preferred' appeared frequently (Percot 2006a: I66, 2006b: 49; Nair 2007: 150). But extreme forms of stigma still operate against nurses in the immigrant community in the US, where upper 'caste' or upper-class Christian families, looking for matrimonial matches, discriminate against nurses' children and even against families with nurses (George 2000: 154). 
Domestic work is not only considered inferior to nursing but is also burdened with being at the root of some of the stigma on nursing for involving the tasks of cleaning. Further, the economic returns to emigrant domestic work are uncertain at best; the household context in which it is performed and the 'invisibility' of the worker only heightens the possibility of sexual abuse as well as the suspicion of sexual transgression. ${ }^{3 \mathrm{I}}$ Emigrant domestic workers bear the full brunt of the stigma in sending and receiving countries (Sabban 2004: 9I; Pattadath 2009). A successful emigrant domestic worker is likely to be the subject of rumours that read success as suspect - the result of 'indecent' ways of moneymaking overseas. In this, their position is comparable to fishprocessing workers from impoverished families in Kerala working in other coastal states. Our own fieldwork shows that these are alternate livelihood options for women in the coastal villages in Trivandrum.

Women workers from Kerala in the fish-processing units of other coastal states are subject to inhumane working and living conditions (Saradamoni I995; Joseph I999). ${ }^{32}$ In the fish-processing units, migrant workers are considered more skilled than local workers but paid less. There have been reports of the sexual abuse of workers, sometimes even leading to their death. Owing to the uncertain nature of livelihoods in the coastal fishing sector, women and sometimes young girls under twenty years of age were recruited by agent-contractors and remained in their control in the destination state (Saradamoni 1995: 194). Not surprisingly, these workers and their families were the subject of gossip, the general perception being that parents were selling their girls into sexual servitude (ibid. I84). ${ }^{33}$

The case of low-status women workers illustrates the gendering of citizenship and sovereignty in the relation of states and societies to 'their' own people. When the exploitation of fish-processing workers was the subject of policy discussion in I984, two alternative measures were suggested: I) to provide work to migrant workers in fishing or allied occupations in Kerala, and 2) to improve living and working conditions of migrant workers in Gujarat. ${ }^{34}$ Whereas an action plan was drawn up to implement the second measure on which, however, no further action was taken, the first of these measures was ruled out categorically, citing the inability of the state to create employment for these women (ibid. I92). It is pertinent here that the prohibition of women's emigration for domestic work - supposedly to protect them from exploitation and sexual abuse - is devoid of concern for their security within the country. Indeed, prohibition may well be forcing women into even more hazardous and less-paying occupations within the country. And though many of these workers are young, the state does not see the need to regulate out-migration or create better work opportunities. 'In 
fact, the possibilities of migrant work are regarded with relief and as matters best left to be decided by individuals' (ibid. I94).

Crucially, relinquishing control over poor women out-migrants does not agitate state policymakers, nor does it pose a threat to sovereignty. In this context, women are rendered symbolic of a notion of national honour/shame that constitutes exploitation only outside its boundaries as a violation. The position of the state and public opinion in the country is echoed - if anything more vocally - by Malayalee civil society groups in the Gulf countries. For instance, a team of researchers who visited Kuwait in 2009 to study the impact of the global recession were particularly exercised over reports of the condition of migrant women domestic workers and convinced that they should be prohibited from going. ${ }^{35}$ Their narration of their experience showed that the Indian Association in Kuwait had made a spectacle of women workers - who had found their way into shelter homes after being battered and sexually abused - in order to argue in favour of a prohibition of such migration. Emigrant civil society groups in the Gulf countries evoke a sense of national shame that reflects the angst of the middle-class emigrant in having to share the emigrant social space with women workers whose mobility and nature of work threaten dominant standards of sexual morality and transgress the gender norm. In this context, a gendered conception of sovereignty impacts on citizenship, rendering the security of poor women particularly fraught - i.e. particularly subject to state scrutiny/protection and particularly open to abuse at one and the same time.

Despite the risks involved, women aspirants seek to emigrate to take up domestic work because they see it as more remunerative than similar work within the country. In this context, the restrictions on their movement demonstrate the collusion on the domains of state legality and social regulation and underscore the viciously gendered and debilitating character of social regulation. Women emigrants and their families are known to resist and violate legal restrictions and other rules for getting clearance from the state. Further, women workers - including domestic workers and nurses - have expressed their 'agency' in the process of migration in categorical terms including a sense of adventure, desire to travel and most of all to escape the conservative confines of Kerala (Percot 2006a: I7I; Pattadath 2009). ${ }^{36}$ However, it is much less clear that they are contesting the gender norms or social perceptions of their activities back home. In fact, nurses and domestic workers seek to legitimise emigration in terms of socially acceptable aspirations such as earning for their families and saving money to be able to pay for the marriages of their daughters, which would include substantial dowries. This mode of legitimisation underlines their investment in the dominant patriarchal conception of womanhood. 'There does not seem 
to be any kind of attempt to change the situation [on dowry]; the nurses save every paisa that they earn by even sacrificing the quality of their diet' (Nair 2007: 150; see also Percot 2006b: 49). ${ }^{37}$

State and social regulations have relegated domestic workers to a social and economic underbelly. The position of foreign domestic workers in the labour market in the UAE is linked to the status of women in the sending countries (Sabban 2004: 89). Up to the I970s, immigrant domestic workers in the UAE were mostly from India, drawing on a long history of cultural and economic relations, but since the late I970s and I990s, the Philippines and Indonesia respectively have grown as source countries. More recently, the numbers of Filipina and Indian domestic workers was 'not growing at the same pace as before', beginning a trend of Indonesians replacing Filipinas in the middle- and upperincome households and Ethiopians replacing Indians in the lowerincome households. Ethnicity and nationality are significant determinants of wage rates of domestic workers in the Gulf States. 'A collegeeducated foreign female domestic worker from the Philippines [in the UAE] is paid the same wage as a high school graduate or a middleschool-educated Filipina, but would earn much more than a foreign female domestic worker from India, regardless of the latter's skills' (Sabban 2004: 95; see also al-Najjar 2004).

It also bears recognition that emigrant women's security and rights depend strongly on appropriate and enforceable legal frameworks in the receiving countries (Chammartin 2004: 22). Labour laws in most Arab League States do not cover women migrant domestic workers, and 'the specificity of their employment relationship is not addressed in national legislation' (ibid. I7). ${ }^{38}$ Further, the kafala (sponsorship) system renders the domestic worker at the mercy of the sponsor/employer, as legally she cannot change her job unless she leaves the country, thus depriving her of bargaining power. Even so, the Indian government has turned away from measures that could alleviate the position of emigrant domestic workers. There is no recognition even of the need for training programmes to upgrade their skills and to orient them towards the higher-end market in destination countries. ${ }^{39}$ While such measures could set off improvements in workers' social profile and serve to challenge popular perceptions of them, the Indian government's restrictions have only strengthened the pejorative way in which domestic workers are perceived. In contrast, the Philippines has been intervening actively to upgrade the skills of workers and to move them out of the domestic work category, while the Indonesian embassy also offers training (Sabban 2004: IO2). ${ }^{40}$

A lack of concern for domestic workers is also apparent in the sharp differences in perspectives when compared to nurses. Emigrant nurses from Kerala benefit hugely from government efforts to promote 
training and to improve the quality of nursing 'by trying to meet the exact international standards in training institutions. Nursing schools are being transformed into colleges, and this sector is being opened to foreign investment' (Percot 2006a: $155^{-156)} \cdot{ }^{4 \mathrm{I}}$ Further, nurses find specific mention as a group not required to take emigration clearance if they have qualifications recognised under the Nursing Council Act of I947. Pertinent here is the economic clout that emigrant nurses wield in the form of financial remittance, which distinguishes them from domestic workers. Thus, restrictions on the movement of domestic workers strengthens a vicious circle of poverty involving low social status and low skill and generates perverse incentives to resort to illegal means of migration.

The Indian government also needs to provide effective safeguards against exploitation and abuse alongside incentivising legal emigration through social protection cover. Problems with the legal framework generate illegal migration and related difficulties, even where sending states are strongly supportive of migrants, as is the case with the Philippines and Indonesia. Nevertheless, in Bahrain for instance, the Philippines embassy mediates in disputes, refers cases to the courts and bears the expenses of litigation and, where possible, attempts to find new employers in association with recruiting agencies. In contrast, the attitude of the Indian embassies towards domestic workers is described as 'negative', 'passive' or 'reluctant'. Al-Najjar (2004: 38) suggests that their attitude stems partly from the Indian government's lack of a clear policy on domestic workers and the embassy's reluctance to confront local families in Bahrain, where a majority of Indians work for influential families. In the UAE, due to the large number of regularised male workers and the decreasing number of foreign female domestic workers, the Indian embassy 'does not give the issue of female domestic workers priority’ (Sabban 2004: IOI).

\section{Conclusion}

In occupations at the lower end of the skill/education hierarchy such as domestic work, there is no dearth of procedural hurdles for aspiring women migrants. Further, policymakers are either unwilling or unable to confront the implications of protectionism. Prohibition as a policy tool pushes the process underground, endangering the security of the women involved and rendering their livelihoods uncertain. It also enables the state to abdicate responsibility towards its citizens who are illegal migrants in another country. If restrictions on movement are supposed to protect women from exploitation, they assume that women (in this case domestic workers) are not subject to similar forms of 
exploitation within their own country or that exploitation within the country is not equally important. In this context, we have argued that protectionism underpinned by gendered conceptions of citizenship and sovereignty participates in the production of controlled informality, driving the emigration process underground and generating a parallel economy based on the exploitation of the poorest segments of workers.

The question of policy-level clarity on domestic workers is clearly important. Measures announced by the government of India in recent years suggest a move towards a more repressive regime. The ability to resist such moves is weakened by the lack of specialised research on this category of workers that is directed at engaging with and informing policy. We also need more efforts to probe the implication of gender in the prevalent understanding of citizenship and sovereignty. To return to another discussion at CDS, more recently in 2008 , on a draft migration policy for India (which is still in the process of preparation), the initial position articulated by the committee in charge of formulating the policy was that gender was not a matter of serious concern because: a) women's migration had gained momentum in the higher-education categories, and b) the flow in depressed categories such as domestic work was on the decline. The latter statement was substantiated by the decline in the number of women emigrating in the ECR category despite evidence that their number is most likely being underestimated due to the use of illegal channels. Further, a survey of domestic workers in Kuwait in 200I showed that I4 out of 43 Indian women workers had an education of up to high school or above (Godfrey et al. 2004), indicating that they may migrate in the ECNR category as well. After some debate, the committee made way for a background note on gender to inform the process of policy formulation. ${ }^{42}$ Whether the policy will respond to the challenges posed by poor women workers in search of livelihood options is an open question.

\section{Notes}

I Regulation of emigration is under the jurisdiction of the central government or the Indian state, hence reference to the state is to the Indian state. As a state/province within the Indian union, Kerala may influence interventions by the Indian government in this regard but cannot frame rules. In this paper we are concerned with the social context in Kerala and the Indian regulatory context.

2 For a sample, see Mathew \& Nair 1978; Nair 1987; Prakash 1998; Zachariah, Mathew \& Rajan 2003; Zachariah, Prakash \& Rajan 2007; Zachariah \& Rajan 2009. There are at least two other significant strands of literature on migration from Kerala. One of these offers a counternarrative on the voluminous flow of remittances and foregrounds its negative consequences for the goods-producing sectors of the state (Harilal \& Joseph 2003). The second strand of literature draws upon ethnographic research to suggest that migration and remittances have reconfigured ethnicities and 
the social fabric and have paved the way for the emergence of a new a class-cum-caste category of cash-wielding people (Osella \& Osella 2000; Kurien 2004). More recently it has been argued that migration has contributed significantly to the 'turnaround' in growth witnessed by Kerala's economy in the I990s (GoK 2006).

3 Allegiance to the gender norm allows this scholarship to present Kerala in a favourable light in comparison with Sri Lanka or the Philippines, where the predominance of women in the emigration process has made visible a 'domestic chaos' emerging from the relative neglect, even abuse, of children and alcoholism among men. In the case of the Philippines, the recent references are mostly to the 'social costs' of migration, a reference here to the consequences of the absence of women as wives and mothers from their domestic responsibilities, which is in contrast with the earlier studies that emphasised how the absence of the husband gave women more decisionmaking power (Ogaya 2006: 126-27).

4 In dealing with women as emigrant workers, the tone of policy-oriented scholarship is set by the quantum of their participation. Kerala is the largest sending state within India, and the most recent survey shows that I4.6 per cent of emigrants from Kerala are women (significantly up from 9.3 per cent in 1998 but down from I7 per cent in 2003) but only about half of them move as workers (Zachariah \& Rajan 2009).

5 Nair (I99I: 24) notes that the total absence of women in his sample of return migrants chosen from the high migrant intensity areas of the state appears to be because 'women from Kerala in employment in the Arab countries - mostly as nurses and other paramedical personnel - are quite few in number and have yet to be repatriated'. However, the same author found in a later study with a sample from Trivandrum alone that one out of six return emigrants were women and that most of them were engaged in menial tasks (Nair I999).

6 The Overseas Development and Employment Promotion Consultants Ltd. (ODEPC) was set up by the government of Kerala way back in I977 as a public-sector recruiting firm for overseas work (http://www.odepc.org). Non Resident Keralite's Affairs Department was set up in 1996 to network, build a data bank and guide aspiring migrants. 'Roots' was set up in 2002 to interface between non-resident Keralites and the government (www.norkaroots.net). Besides, in Kerala, feeder organisations of the government such as the Bureau of Economics and Statistics have conducted studies on migration and the utilisation of remittances (GoK 1987, I994). Numerous conferences have been held by the state government to discuss the issue.

7 The Emigration Act of 1983 , Section 22 (I).

8 Emigration clearance is provided on the basis of valid documents like work contract, employment visa, insurance policy, etc. and an affidavit that s/he is emigrating on his/her own free will and is aware of the details.

9 This recognition underpins the ongoing attempts on the part of the Indian government to enact a new emigration law and formulate a national policy on international migration.

Io See pre-departure training manuals for various countries prepared by CDS for the MOIA, accessible on the websites of both these organisations.

II Office Memorandum no S-IIO25/57/2000-Emig, dated 9 July 2002, Emigration Division, Ministry of Labour.

I2 This order also directed all the POEs to accept the date of birth mentioned in the passport as proof of age for the purpose; Office Memorandum dated 20 November 2003, Emigration Division, Ministry of Labour.

I3 Protectors of Emigrants were appointed by the colonial Indian government in response to increasing reports of ill treatment of indentured workers in the destination countries and outcries that indenture represented yet another form of slavery (Tinker 
I974). The first Protector of Emigrants was established at Calcutta in I843, and Bombay and Madras also established offices subsequently (Vetcha and Bhaskar 2003).

I4 The Passport Act of 1967 tightened the passport regime, and the individual discretion to decide whether to migrate with or without a passport as allowed by the Passport Act of 1920 was removed.

I5 ECR suspension allows ECR passport holders to visit countries requiring emigration clearance. This channel has been used to emigrate for expatriate work on visit visas. However, the ECR suspension has been repealed with effect from I October 2007, making it possible for people to 'visit' without a 'suspension'.

I6 Significantly, in this context, Malayalee social scientists even exude a sense of expansionism, recommending in one instance that the geography and culture of the Gulf region should be included in the school syllabus in Kerala, as it is likely to be more relevant to students here than learning about other, more distant regions of India. Comment at an open seminar, 'The Gulf Revisited' at the Centre for Development Studies on I5 July 2004. See also Zachariah and Rajan (2004: 7).

I7 Letter of Under Secretary, Ministry of Labour, to all POEs, dated 4 June I999.

I8 Letter of Under Secretary, Ministry of Labour, to all POEs, dated 29 May 2000.

I9 Office Memorandum with the Subject 'Clearance of Indian citizens for deployment as housemaids in Kuwait', Ministry of Labour, dated 26 February 2002.

20 Office Memorandum with the subject 'Measures for protection of Indian emigrants', dated 4 May 2007, MOIA, Emigration Policy Division.

2I Letter by Under Secretary to the Government of India, MOIA to all POEs, dated 2I May 2007.

22 By that time, the qualification for getting an ECNR passport had been lowered to Matriculation pass. Letter by Under Secretary to the Government of India, MOIA, Emigration Division, dated I August 2007.

23 Letter by Under secretary to the Government of India, MOIA Emigration Section, to all POEs, dated I2 September 2007.

24 There has been a spate of news reports in recent months on illegal recruiting agents and the nexus of corruption involving state officials. In a recent incident shrouded in mystery, following the arrest of the POE Chennai and a subsequent raid of the PGE's office and residence by the CBI, the PGE killed several members of his family and committed suicide, leaving a note saying, 'I am innocent. My simplicity betrayed me'. ('CBI arrests Protector of Emigrants, two agents on corruption charges', in The Hindu, 2I July 2009; 'CBI to check antecedent of emigrants at random', in The Hindu, 22 July 2009; 'IAS officer, four family members found dead', in The Hindu, I August 2009; 'Probe into multiple murder case begins' in The Hindu, 2 August 2009).

25 Newspaper reports of a recent instance of 'illegal migration' from Kerala to Israel referred to the mode of circumvention of state procedures. Deportees said that 'a woman emigration officer at the Chennai airport had initially refused to clear them for travel. However, the agent who was with the group had then spoken to two other officers who ushered the woman away and gave them emigration clearance' ('Visa Racket: Kerala Police order Investigation', in The Hindu, I6 October 20I0). There are numerous reports of the circumvention of emigration ('No end to illegal recruitment of women for the Gulf, in The Hindu, 28 May 2005; '4I Kuwait-bound women arrested by Hyderabad Police', in www.rediff.com, 2I September 2000; 'Kuwait-bound woman arrested', in The Times of India, I5 May 2008;). Owing to the increasing number of complaints against POE offices, they are now under the scanner of the Vigilance and Anti-Corruption Bureau ('Role of Emigration Officials under Scrutiny', in The Hindu, I August 2009).

26 This term is familiar to Gulf migrants and to people in the northern coastal region. It came into the media limelight in the wake of an air crash in 2010 in the southern city 
of Mangalore that involved a passenger traveling on a passport in the name of another migrant who was at that time safe and in the Gulf. There were at least ten passengers travelling on fake passports in the ill-fated aircraft (Radhakrishnan 20I0). The production of fake passports entails information sharing by travel agents regarding authentic passport holders. Other practices are to acquire passports through theft or at a price from desperate people and replace the photograph on it with a new one (referred to as thala vettal or chopping off the head) or simply to sell the original passport of one person to another person who bears a strong resemblance. The IG (Intelligence), Kerala Police, who is in charge of immigration at all the three international airports in the state, notes that a passport can be bought for anywhere from 65,000 to 70,000 Indian rupees and is usually bought by poorer migrants. With new technology that can detect tampering, there has been an increase in the seizure of false passports. An official is quoted as saying that 42 cases were detected between May and June 2010 alone (Radhakrishnan 20I0).

27 The employer usually also takes possession of her legal documents (Godfrey et al. 2004; Sabban 2004).

28 Police officials note that they are unable to make headway in investigations of fake passports because the users know nothing more than the name of the agent from who they purchased it (Radhakrishnan 20I0).

29 This ostensible 'rescue' also serves as a mode of recruitment of users of the parallel network in the Gulf, whose agents may strike up emotional ties with women workers and use them to access the earnings of women workers (Personal conversation with Bindulakshmi Pattadath).

30 In a recent survey of recruiting agents in India, only 4.7 per cent admitted that they recruited housemaids for overseas employment (Rajan et al. 2009).

3I Within the Indian context too, women domestic workers struggle to maintain their sexual integrity in the face of constant suspicion from their husbands and harassment from male employers (Kaur 2006: 209).

32 The studies were prepared by the Institute of Social Studies Trust, New Delhi and Indian Institute of Management, Ahmedabad.

33 Despite this depressing scenario, women valued the opportunity of a livelihood offered by migration, which allowed them to contribute to their families and to save for their own dowries. But more importantly, they spoke of not wanting to go back and live under the restrictions they were subject to in Kerala (Joseph 1999), which says volumes about the nature of social regulation in the state.

34 This was at a roundtable discussion in Trivandrum in the wake of a study undertaken for the Ministry of Labour by the Institute of Social Sciences Trust, New Delhi, following publicity over the death of a young worker from Kerala.

35 Personal conversation with $\mathrm{M}$ Parameswaran and $\mathrm{K}$ Pushpangadan, Centre for Development Studies, Trivandrum.

36 Emigrant housemaids have the mobility and freedom to socialise in ways that are restricted in Kerala. 'The ayahs are a particularly conspicuous part of the local scene in several Gulf States. In Kuwait, for example, a thousand or more Indian ayahs can be seen on a Sunday evening in front of the city's Catholic Church talking and strolling with one another and with young Indian boys' (Weiner 2007: 138; see also Sabban 2004).

37 Further, nurses who returned after a stint of migration were observed to withdraw from work when there was no economic compulsion unless they could move into higher status work (Percot 2006a: I62).

38 Within India too, there is a lack of clarity regarding the status of the domestic worker, and domestic work remains unregulated and is not even covered under the minimum wages act. In the wake of media reports of exploitation of tribal girls by placement 
agencies and employers in Delhi, efforts were initiated in 2008 to legislate for the protection of domestic workers, but the Bill drafted by the National Women's Commission is still pending (Neetha 2008: 28).

39 Ironically, when the Kerala State Women's Development Corporation announced plans recently to launch a finishing school, it was to impart personality and communication skills for nursing graduates seeking jobs outside the state (The Hindu, I6 July 2009). An array of finishing schools funded by the state government under the eleventh plan (2006-II) to augment women's chances of employment also did not include domestic work (Government of Kerala 2009).

40 It is notable that in these countries there has been government support for these workers despite considerable criticism by non-governmental organisations and religious groups (Ogaya 2006).

4I It is also notable that more than a third of nursing schools are located in Kerala. Moreover, Malayalee women go in large numbers all over India to study nursing (ibid. I58).

42 CDS, Background Report for National Policy on International Migration 2009 (www. cds.edu). 



\title{
9 Mainland Chinese Migrants in Taiwan, 1895-1945
}

\author{
The Drawbacks of Being Legal
}

Leo Douw

In Taiwan, a population of migrant workers from mainland China came into being during the period when the Japanese colonial regime was in power, from I895 to I945. In the I930s, their numbers rose to at least 60,000 . These migrants worked and lived in the rapidly developing big cities of Taiwan, where they supplemented the labour market. Before the Japanese occupied the island, migrants from mainland China had worked and settled continually in Taiwan over a period of more than two centuries. This had never given rise to problems concerning their legal status, because they remained subjects of the Chinese empire just as they had been on the mainland. After 1895, however, the Japanese occupation caused them to suffer from the contradictions inherent in the legal status that the colonial regime imposed on them. This was in the first place because the migrants were officially categorised as foreigners without a right to acquire citizenship rights, whereas in actual fact they were in the process of settling permanently, as their predecessors had tended to for centuries. As a consequence, they did not acquire access to state resources which their actual status would have justified. Furthermore, they were also more easily discriminated against and exploited. Their categorisation as foreigners was defective for yet another reason. Most of the migrants came from the same districts in the Fujian and Guangdong provinces in South China from where the native Taiwanese also hailed from, and were linguistically and culturally close to the latter. Often, they also had family or friendship ties with them. Therefore, Chinese immigrant workers were only foreigners in the strictly political and legal sense of the word.

For both reasons, the Taiwanese colonial immigration regime is a good example of one central object of research in this book - namely how states may represent and categorise people in a certain way but 'fail to capture the very phenomena they manifestly aim to order' (see introduction). By allowing the migrants to stay on despite their formal temporary status, the Japanese colonial state created a 'regime of 
permissiveness' for the migrants, which in turn generated a 'zone of licitness' for them in Taiwanese society (see introduction). It would not be precise to say that this 'zone of licitness' was located outside the law in a literal sense because the migrants' presence in Taiwan in itself was formally legal. But since permanent settlement found itself clearly outside the official discourse on immigration, it would have required additional legislation on naturalisation in the longer term. The only reason why this did not come about was the Japanese colonial state's interest in maintaining the status quo. It did so for compelling social and political reasons, which will be explained in the subsequent paragraphs. Of course, the spatial and cultural closeness of mainland China added to the difficulty of achieving this for the Japanese colonialists, because it made cross-border traffic and assimilation easier (see introduction). Under these circumstances, the rift between the migrants' legal status and the actual situation in which they found themselves became even deeper. This fundamental ambiguity lasted throughout the colonial period.

The special situation of this group of migrant workers enables us to critically engage with some of the basic contentions of the present book. It seems, in particular, that the great relevance that the editors of this volume allot to the position of migrants between legality and illegality, and which they consider as 'dim', needs to be qualified. The Taiwanese case shows that migrants need not be illegal in order to suffer from an inadequate legal status and all the ensuing disadvantages: the mainland Chinese migrants in colonial Taiwan were not represented in politics, had no access to regular facilities such as education and social care, suffered from all kinds of economic exploitation, could not change their profession and were liable to being removed from the country in case of a criminal offense. All this was possible despite their being formally legal. It seems justified to consider their position to be just as 'dim' as the position of the migrants, whose status can be circumscribed as 'illegal but licit'. In other words, legality may work against migrants just as much as illegality may. The immigration regime in colonial Taiwan was similar to that in present-day Singapore in its high measure of elaborateness and the rigidity of its implementation. Yet, as in the case of Singapore, it could not prevent a 'zone of licitness' from emerging where the state did not act according to its own professed intentions (see introduction). In colonial Taiwan, this was not so much a matter of officials who bent the rules according to their own interests but rather one of officials and businesspeople who had a stake in a system that in itself was consistent but at the same time was fundamentally wrong and unjust. As a result, the migrants simply ignored it or used it discursively to advance their own interests. It is the purpose of this chapter to describe how this worked and how the migrants went about it. ${ }^{\text {I }}$ 


\section{The Emergence of a 'Zone of Licitness' in Colonial Taiwan: How to Become a Foreign Settler}

\section{The immigration regime}

The migrants from mainland China became foreigners in Taiwan as a consequence of the Treaty of Shimonoseki following China's defeat in the first Sino-Japanese War (1894-95). By this treaty, China ceded Taiwan to Japan. Before I895, mainland Chinese migrants had been settling in Taiwan as Chinese subjects for more than two centuries. In fact, until at least the I86os, Taiwan had been a Chinese frontier area which had become populated gradually by migration, mostly from a limited number of rural districts in South China. The Treaty of Shimonoseki stipulated that the inhabitants of Taiwan would formally become Japanese subjects on 8 May I897, exactly two years after the signing of the treaty, unless they applied for Chinese nationality before that date. Afterwards, all migrants from mainland China would automatically be treated as foreigners. In state documents, they were referred to as 'people from China' (shinkokujin or, after I920, shinajin, see Wu I99I: I4) and in common parlance they were called 'Chinese overseas in Taiwan' (Taiwan huaqiao in Chinese or Taiwan kakyō in Japanese) (Wu I99I: I, 83; Xu I99rb: 99-I00). Since the early twentieth century, the term 'Chinese overseas' was applied to all Chinese migrants in foreign countries all over the world, of which the migrants to Taiwan thus became a part. For the same reason, the previous pattern of assimilation into local society was interrupted, and full assimilation had become nearly impossible. Naturalisation was only granted to Chinese subjects of outstanding merits for the Japanese colonial state, who therefore came from elite families, whereas practically all migrants were of modest origins. Despite these impediments, the number of migrants grew quite steadily from zero on 8 May I897 to 60,000 during the I930s, which is usually mentioned as having been the peak (Wu I991: 23-24).

The migrants' foreigner status was reflected in the manner in which their stay in Taiwan was institutionalised. First, control was exercised by licensing one company with the monopoly over the recruitment of the migrants. This was the Nanguo Company, headed by a Japanese director; it was established in I904 and survived until its demise in 1940. A maximum of I०,000 immigrants each year was set, and a fee was made payable to the state (Wu I991: 45-46). The Nanguo Company was responsible for the migrants' behaviour until they checked out again and returned home. Secondly, the Japanese thought it appropriate for the migrants from China to organise themselves in huiguan - associations based on kinship, profession or, as was usually the case in Taiwan, regional origins or hometowns (qiaoxiang). This was how the Japanese perceived Chinese migrants to organise themselves whenever 
they resided abroad, including Japan. At the beginning, during the Igoos and I9IOs, these associations were usually initiated by the Japanese and were led by businessmen (Wu I991: 46). They were part of the control mechanisms imposed on the migrants, which just like the Nanguo Company's monopoly, was deemed necessary during this period. This was mostly because insurrections against the colonial regime by the native Taiwanese population were common. Uprisings were only slowly suppressed and the Japanese feared that support might be provided by insurrectionists from mainland China, who might penetrate Taiwan through the migration channels. Lastly, control was exercised through the incorporation of the migrants into the hoko system (Chinese: baojia system), which was established during this time for the Taiwanese population as a whole and served as a taxing apparatus and as a policing devise (Ts'ai 2009: 93-II8; Wu I991: 46; Xu I993: 69, 74). Contrary to their connections with the Nanguo Company and the hometown associations, which marked them clearly as foreigners, their incorporation into the hoko system may seem to have made the migrants part of the native control system, because all native Taiwanese equally were involved in it, and foreigners were excluded in principle. But this was not how the migrants experienced it, as will be shown below, as it helped articulate their foreigner status rather than attenuate it.

These institutions were part of a much broader-ranging set of regulations which were intended to restrain the flow of migrants from mainland China. Legislation began at the onset of Japanese rule and ended in I920 with an elaborate system of control which, according to the existing literature, barely left any space for illegal migration to Taiwan (Wu I991: 146). Their main purpose was to guarantee a steady flow of workers into Taiwan, who were needed to relax the tensions on the labour market and who always made up some 80 per cent of the total number of migrants. Aside from the workers, however, there were others too who wished to visit Taiwan or settle there, mostly from the middle classes and the professions. Until I9I9, there was a lively trade in passports allotted to the workers, who sold them at a profit. A distinction was therefore made between 'workers from China' (huagong) and others, so that the latter could no longer slip into Taiwan on passports sold to them illegally by the former. The corollary of this strict regulation was that migrants were free to work and reside wherever they liked upon crossing Taiwan's borders (Wu I99I: I5, I45-I46). Apparently this regime worked so well that it wasn't changed for the rest of the colonial period. 


\section{The state's interest in a foreign labour force}

Taiwan's 'zone of licitness' and its 'regime of permissiveness' originated from similar public concerns that usually underlay migrants' 'illegal but licit' condition. In colonial Taiwan, economic motives stimulated immigration, whereas political and social ones impeded it. Immigration was needed for the rapidly developing Taiwanese economy, an important project for the colonial state. The orientation of the Taiwanese economy towards the Japanese market, which took off from the outset of colonialism, was only one part of this. Aside from providing commodities such as rice and sugar for the Japanese market and making big investments in industries and harbours which could make Japan more competitive with the other colonial powers, the Japanese also considered the development of Taiwan as a model project that served to enhance its status as a modern nation. Finally, from the I920s at the latest, Taiwan increased in importance as a strategic vantage point from which to advance southward and penetrate South China and Southeast Asia (Ka 1995; Lin 1997).

The aims of the highly ambitious colonial state were helped by the permanent wage differential between South China and Taiwan, and both together motivated most of the continual migration flow to Taiwan. Wages could be up to three or five times as high in Taiwan as on the mainland, whereas the cost of living was lower (Wu I99I: I44, I47; Xu I99Ib: II4). The Japanese state benefited because it wished to lower the costs of its ambitious modernisation programme, but employers, who increasingly came from the Japanese colonial elite, profited as well. Wages for migrants amounted to four-fifths of Taiwanese wages and one-third of Japanese wages (Wu r99i: 46, I64). The colonial government never even considered liberalisation of the market for migrant labour, mainly for political reasons but probably also because it profited sufficiently despite the restraints of the current immigration regime.

One should even wonder whether migration controls interfered much with the size of the migration flow. It is clear that the yearly number of Chinese migrants to Taiwan deviated rather significantly over time from the maximum of Io,००० set by the Japanese, either by exceeding it or by being lower. Despite intense efforts to regulate immigration from mainland China, its size and patterns had a life of their own. Until the I920s, immigration was consistently lower than the legal maximum of I0,000, whereas during the latter half of the I920s it was consistently higher, and also return rates were lower. During the I920s and I930s, the deteriorating political situation in Fujian province (located in mainland China, where most of the migrants came from), was a major push factor for immigration, in addition to the economic stimulus. In accordance with these data, the Taiwanese historian Wu 
Wenxing claims that the size of the migration flows fluctuated with migrations to other parts of the world from the same districts in South China where the migrants to Taiwan came from (Wu I99I: I47). In this context it is noteworthy that during the colonial period as a whole, the number of migrant workers as part of the total workforce declined from two to one per cent if one calculates from the official data; but even if higher estimates are used (see below), their number was at a stable two per cent.

These data throw a peculiar light on debates that took place in the Taiwanese public media and in the Japanese parliament in Tokyo on the desirability of labour migration from China (Wu I99I: 9-I0). The debates began in the late I89os, when immigration was prohibited for a number of years, and continued until the early ig20s when questions were raised in the public media as to whether Japanese and Taiwanese labour would not suffice for Taiwan's needs. Like in China, wages in Japan were lower than in Taiwan, yet for non-economic reasons Japanese workers were unwilling to relocate. Public opinion resented the inflow of migrants from mainland China on grounds of social and political undesirability. Also, Taiwanese workers feared the competition from the migrants, a factor that continued to play a role even after the I920s when a general consensus had grown that labour migrants were needed for solid economic reasons (Xu I99Ib: II4). It also made the cooperation of the migrants in the Taiwanese labour movement difficult at times, as will be shown below. In actual fact, however, the available data indicate that migrant workers were a supplementary workforce and fears that a liberal immigration regime would undermine the bargaining position of the native Taiwanese workers, was largely unjustified. Apparently, the domestic motivation for the restriction of immigration was mainly socially motivated: an irrational fear of competition, invigorated by a social aversion to the immigrants who on account of their condition in Taiwan formed an underclass. Because of the pervasive economic motive, but also because liberalisation could be supposed to have limited effects, it is understandable that labour contracts were not legally limited to a fixed period of time and migrants were effectively allowed an unlimited stay in Taiwan. But as the following paragraphs will show, this observation also validates the many statements made by the migrants' organisations claiming that the immigration regime was just another closed circuit from which a limited number of state officials, businesspeople and the Nanguo Company profited at the expense of the migrants.

The international scenario added greatly to this situation. It was predominantly determined by the ever-increasing political tensions between China and Japan, and provided a particularly strong motive for migration control in the Taiwanese case and thereby determined to a 
large extent the conditions under which the migrants from mainland China lived. Maybe the best example of this is the scare that the Japanese military invasions of China of I93I and I937 caused: a huge number of migrants left Taiwan instantaneously; after I93I, they returned and kept growing in number, but after I937 their numbers remained at the same level until the end of the war ended their status as migrants (Wu I991: I50; $\mathrm{Xu}$ I993).

From the perspective of the Japanese colonialists, political agitation among workers by insurgents was to be feared throughout the I920s and I930s also by the increasing confidence of the Nationalist and Communist propagandists, who could have infiltrated easily into the island from mainland China if migration had been left unchecked. By the late I920s, new migrants were recruited over a vast area in Central and South China. The mainstay still came from the Fujian and Guangdong provinces, but the Jiangxi and Zhejiang provinces also contributed (Wu I99ז: I59-16r). This may have encumbered the migrants' possibilities to unite, at a time when their organisation as an interest group was at its high point. There was no reason, however, for the Japanese government to withdraw the allotment of special status to them.

In short, there was sufficient reason for the colonial state to keep Chinese migrant workers separate from the native population, despite the fact that they were ethnically akin. They were made subservient to the colonial economy of Taiwan, which in the course of time became less integrated than before with the Chinese economy and more with Japan's. Combined with the distress in their home country, the migrants had strong motives to settle in Taiwan. Of course, many of them kept their connections with the home base: they sent remittances back home and found a refuge there in times of distress. Yet the tendency to settle was so strong that serious problems in their social status resulted for this population of migrants and continued to bother the colonial state.

\section{The migrants' interest in settlement}

Despite their thoroughly institutionalised foreigner status in colonial Taiwan, permanent settlement became more normal for Chinese migrants as time passed by. During the first decades of colonial rule, most migration from China was still circular or had a temporary character. The return rate of migrants was at a stable average of 90 per cent until around I920. Customs registration show an average surplus of around I,O०० immigrants over return migrants who settled for longer periods, and may have opted for permanent settlement. In this way, their numbers reached around 25,000 by the early I 220 s against around I0,000 
yearly returnees. This means that by that time they had become substantial in number and also that settlement of longer duration had overtaken temporary migration in size (Wu I991: 45).

There are no records of individual wishes, life experiences and political attitudes of the migrants either from archives or personal memoirs (see note I). Yet the trend towards permanent settlement is not difficult to establish. From the I920s onwards, when the return rate declined to 80 per cent, there was indeed a distinct trend towards settling in Taiwan. The clearest sign of this trend is that the length of the migrants' stay in Taiwan increased substantially after I920. In I940, twothirds of the migrants had stayed longer than five years in Taiwan. Of these, about half - more than one-third of the total - had stayed longer than ten years; the fact that II.2 per cent had stayed longer than twenty years indicates that the trend towards settlement had intensified after I920. The remaining one third of the migrants had stayed for one to five years; only 6.9 per cent can be considered as definitely temporary workers: they had stayed shorter than one year (Wu I99I: I54-I55).

The nearness of the migrants' hometowns also plays a role in this. The rate of return among Chinese migrants to Taiwan was higher than the average of 70 per cent calculated by McKeown for Chinese emigrants worldwide (20I0: III). This was because traffic back home was easier and links back home were easier to maintain. For the same reason, families could easier cross over to Taiwan and join the male migrants. This is indeed what happened from the beginning and their number increased over time; after I920, accompanying families were registered as such. Unfortunately it is impossible to distinguish women and children in the statistics, but a fair estimate is that the proportion of women in the migrant population increased from five per cent in I905 to one-quarter in the mid-I920s. It further increased to one-third in the mid-I930s. This means that married migrants had overtaken unmarried ones during the same span of time when their numbers rose to their highest point (Wu I99I: 23, I5I-I53). The fact that the number of marriages with native Taiwanese women also increased (Wu I99I: I5I) confirms the solid trend towards settlement.

The continually booming labour market does not provide much of an argument for why migrants wouldn't wish to settle. The push and pull factors that motivated migrants in South China to migrate towards Taiwan changed somewhat over time, but as we saw, they were basically determined by the vastly different wage levels of both areas; these continued from long before 1895 all through the colonial period (Wu I99I: I44 ff). Taiwan had been in an economic upsurge during the second half of the nineteenth century, when markets for Taiwan's main export commodities - rice and sugar - expanded. Tea and camphor were also important, especially after the I880s when Taiwan was made into a 
province from having been a prefecture under Fujian province and the governor Liu Mingchuan began to aggressively modernise Taiwan's economy (Long I99I: 20-22; Ka I995: 33-35; Katz 2005: 28). Both the general economic situation and Liu's concerted activity did much to increase the flow of migrant workers to Taiwan (Wu I99I: I43). The Japanese modernisation effort kept the flow going and directed it mainly to the fast-growing urban centres, especially Taipei, Tainan and Kaohsiung (Wu I991: 163). ${ }^{2}$

During the I920s and the I930s, the differences between the South Chinese and Taiwanese economies increased further. The shift of the Taiwanese economy from an orientation toward Chinese markets towards integration with the Japanese imperial economy was completed, and rapid growth followed. This kept the flow of migrant workers going at a higher pace than had been the case before 1920. As we saw, during the I920s and early I930s, the legal maximum of I0,000 immigrants per year was exceeded a number of times, and new sources of labour were explored and used, especially for work in the mines newly opened up by the colonial government after 1928 . This added some 3,000 to 4,000 miners each year, mainly from Wenzhou in Zhejiang province, nearly doubling their numbers to about 46,000 in the early I930s (Wu I99I: I47-I48). These numbers may even have been higher, since the precise number of settlers is subject to some debate. A number of I00,000 for the I930s were usually claimed by the Chinese associations and by the Chinese Consulate. The numbers that are commonly quoted are based on the Japanese Customs registration (Wu I99I: I48-I49) and on the official household registration system (Wu I99I: I5I-I53). By somewhat different methods of counting, however, Wu Wenxing finds a possible total of 140,000 to I50,000. This estimate includes people with a Chinese and a Japanese nationality, who in the Japanese counting were omitted (Wu I99I: I5I), as well as children of migrants, whom the Japanese registered as 'without nationality' until I920 (Wu I991: I53). Wu also argued that illegal migration could not always be prevented no matter how tough controls were, mainly because the island was geographically sufficiently open to the mainland (Wu 199I: I47-I48; personal interview with Wu Wenxing on 27 April 2006).

By its continuing contrast with the mainland Chinese economy, the pull of Taiwanese economic development therefore did nothing to prevent Chinese migrants from settling. The migrants' occupations were not clearly of a temporary character either nor very distinct from the occupations of the native Taiwanese, such as carpenters, barbers and prostitutes. Certainly there were sectors where they really found an exclusive niche, such as mining from the late i920s, when Japan's militarisation took off, or rickshaw pulling during most of the period (Wu 
I99I: 156-I57). But in most other sectors they supplemented the existing native workers and small businesses. One-third of the immigrants registered their profession under 'various services', because if a circumscribed occupation was chosen, this could not legally be left afterwards (Wu I99I: 22-23). Moreover, the visa label 'worker from China' included all kinds of artisans and handicraftsmen who would not normally be classified as workers. This made the labour force quite diverse and predominantly urban. There was a wide array of typically urban occupations such as the above-mentioned rickshaw pullers, barbers and prostitutes. Work on plantations and in mines was a relatively small part of the total, with the former declining during this period and the latter increasing, as we saw. Also, many migrants worked in the foreign, predominantly Japanese, export sector (Wu I991: 156-163).

The colonial authorities allowed this drive among the migrants to settle and only outwardly restrained it through legislation. This peculiar 'regime of permissiveness' thus allowed a 'zone of licitness' to emerge in which state officials, employers and labour brokers - including the Nanguo Company - were free to exploit the migrants, who were legally prevented from fully integrating with the local society.

\section{The consequences of being legal foreigners}

Economic exploitation was possible, first, by the numerous fees that had to be paid to the labour brokers on both sides of the borders and to the Nanguo Company for passage to Taiwan. Informal amounts were often added to the official fee in various ways (Wu r991: 45-46; on the payment of informal fees by Chinese migrants in our times, see Kalir and $\mathrm{Li}$ in this volume). The Japanese colonial state profited from the fee that the Nanguo Company paid per migrant and from the special fee for migrants due upon enlistment in the hoko system. Secondly, because of their special status, wages could be kept low, also because the migrants were supposed to look after their own social care. Their children were also not allowed to attend schools, which also saved state expenditure. Their literacy rate was distinctly lower, and their knowledge of Japanese noticeably less than was the case among the native Taiwanese population (Wu I991: 46). Small wonder, then, that many of the migrants landed in an underclass position and that the mainland Chinese migrants as a whole suffered from a bad press: their criminality rate was higher than average, and they were widely accused of using drugs and prostitutes (Wu I99I: I64-I68; Xu I99Ib: II2-II8). Pressure could be mounted upon the migrants because they were liable to be expelled in case of a criminal offense. They were also the object of crude and discriminatory treatment by officials: they were quicker to be beaten and tight-roped by the police than native Taiwanese were (Wu 
I99I: 46). Finally, as we saw, they were not allowed to change the profession they had registered with Customs which, just as the lack of educational facilities for their children, impeded their mobility and prospects for the future (Wu I991: 22-23).

In view of these conditions, it is not surprising that the migrants' organisations began to articulate a political demand for equal treatment during the I920s and I930s. By that time their numbers had risen sufficiently, especially in the cities, and their political awareness was growing. Because of their separate legal status and the disadvantages these brought with them, they felt that they were treated as third-ranking citizens, behind the Japanese and the Taiwanese, and claimed equal opportunity in education and representation with the colonial state (Wu I99I: 48, 64-66). Their other demands were mostly in line with this but at the same time reflected their foreigner status: they included access to educational facilities, liberalisation of the immigration regime including the abolition of the Nanguo Company, withdrawal from the hoko system and the establishment of a Chinese Consulate (Wu r99r: 26-28, 48-49, 52-54, 64-66; Xu I993: 73-8r). The former two demands, if met, would have created far better conditions for assimilation into Taiwanese society. The withdrawal from the hoko system and the establishment of a Chinese Consulate came straight from the migrants' foreigner status and their status as 'Chinese overseas in Taiwan' but should be interpreted as measures to improve their situation locally and thus support settlement rather than sojourning. Being incorporated into the hoko system entailed payment of a special tax, for which the system was considered as one form of exploitation just like the Nanguo Company's monopoly (Wu I99I: 64-66; Xu I993: 69, 74). ${ }^{3}$ The establishment of a Chinese Consulate could certainly be interpreted as a sign of allegiance to China; at the same time, however, it was one way to be better represented with the colonial state and try and acquire some measure of leverage over it.

Obviously, their official foreigner status made the mainland Chinese migrants a disadvantaged social group. At the same time, however, contrary to the condition of most migrants elsewhere, it provided them with the institutional and discursive implements to articulate their interests.

\section{The Migrants' Discourse: Being Chinese and the Quest for an Equal Status}

It is evident that the labels 'Chinese overseas in Taiwan' and 'people from China' were incorrect if one considers the cultural and linguistic affinity that existed between the migrants and the native Taiwanese, and 
their linkages through family and friendship ties. Yet these labels provided the migrants with a discourse that could be used to become organised and vent their social and political demands, in a situation that allowed them preciously little manoeuvring space otherwise. The colonial state remained repressive throughout its reign in Taiwan, despite the comparatively open political atmosphere of the I920s and early I930s. On the basis of their status as Chinese descendants, the migrants legitimately sought allies in China but found little support. This is remarkable because discourses of Chineseness had been purposely created and developed by successive Chinese governments in order to gain the support of Chinese descendants abroad, as will be shown below. At the same time, of course, the open enmity between China and Japan grossly hindered Chinese state activity in Taiwan. For this reason, the migrants relied mostly on their own efforts and on the stimulants provided by the Taiwanese native opposition movement. The opposition found a motive to make the migrants join its actions in the unique Chinese descent they shared.

\section{Self-organisation}

The main vehicles for social action by the migrants were the workers' friendship associations (gongyouhui), organised on the basis of professions, and the above-mentioned hometown associations. The friendship organisations had been established as mutual aid societies in the absence of provisions for health and social care by the employers and the state (Wu I991: 48-49, 53). Originally, they were explicitly apolitical and only served to support members who got into trouble, but when the political climate changed in the course of the I920s and the migrants had become self-confident and large in number, they quickly proliferated and became one channel for the mobilisation of the migrant workers. During the period I924-I93I, they were actively involved in the organisation of strikes (Wu I99I: II, 53). Their independence appears clearly from the fact that they were quicker to organise than the native Taiwanese labour movement, with whom they collaborated despite the fact that differences also existed and sometimes resulted in conflicts. One important binding factor was the activity of the People's Party, especially its leading member Jiang Weishui - to whom we will return shortly - which mobilised the native opposition against Japanese colonial rule. The migrant workers were on their way to establishing an island-wide labour union right before the labour movement collapsed (Wu I991: 53, 56-59, 68-69). Their concrete results were meagre, and the migrants' degree of organisation was relatively low (Wu I99I: 5354), but their persistent actions over a relatively long period of time attest to their significance as participants in a social movement. They 
were important also because their organisations were widely spread over the main sectors in which migrants worked (Wu I99I: 54), and because their activity linked up with the initiatives of the hometown associations: these became more vocal too during the I920s (Wu I991: 48).

We have mentioned that the establishment of hometown associations was stimulated by the Japanese colonialists in collision with businesspeople as a means to control the migrant workers (Wu I991: II, 46). This did not work very well, but the associations stayed on and when the political climate became more open during the I920s, they turned into independent organisations that learned how to organise on a national, island-wide basis and become a mouthpiece for migrants' interests. In the second half of the I920s, they were relatively successful in transcending the localised character of most hometown-based organisational principles. Since the associations were based on the province or district of provenance of their members, regional antagonisms impeded collaboration. Contradictions remained but were at least nominally overcome when the Chinese General Association (Zhonghua Zong Huiguan) was established in 1927. Its chairman, Gao Minghong, became the most vocal and well known among the representatives of migrants' interests (Wu I991: 49-50, I59-160; Xu I992: 18-22; Xu I993: 68-69).

It is not clear from the existing sources how exactly the associations liaised with the migrant workers among their constituency. As a percentage of the total number of migrants, the number of members of the hometown associations was limited, declining from a high of I2 per cent in 1926 to a much lower three to five per cent after the political turning point of 193I. Its members belonged to the middle-class section of the migrants rather than the workers, properly speaking. The membership fee was mentioned as an impediment to membership for most of the workers but was also contested for that reason (Wu I99I: 50; Xu I993: 67). Nonetheless the associations addressed the problems of the migrant workers very explicitly and therefore can rightfully be considered as their most important mouthpiece. The Chinese General Association took the lead in all the struggles for the improvement of the migrant workers' fate and maintained relations with the Japanese colonialists. At the same time, it was tightly supervised. Its chairman Gao Minghong received invitations for receptions by the Japanese but also had to register with the local police office on a weekly basis $(\mathrm{Xu}$ I992: 32).

\section{Lacking support from China}

It is noteworthy how little support the associations received from governments in mainland China. Since the beginning of the twentieth century, these governments had successively made efforts to line up with 
communities of Chinese descendants outside China and remind them of their blood ties with China, which through the validation of ius sanguinis entailed Chinese citizenship. By calling them 'Chinese overseas' (huaqiao), or literally 'Chinese sojourners', they encouraged them to return to China and let their country benefit from their knowledge and earnings abroad (Zhuang I989; Duara 1999). This fabric of Chinese overseas bureaus and diplomacy, based on the Chinese sojourner discourse, was maintained throughout the twentieth century and still exists nowadays (Ong \& Nonini 1997; Douw 1999). Before the Second World War, China's influence was greatest in the colonial empires of Southeast Asia, where the majority of Chinese descendants lived, but due to China's weakness it could barely pose a threat to the colonialism of the contemporary Western big powers who reigned there. At times, however, it could inspire a wave of patriotism and inspire confidence among Chinese descendants whenever China seemed on the rise or stimulate feelings of allegiance whenever it was in jeopardy.

In Taiwan, the increasingly inimical relationship between China and Japan made the situation even less congenial to supportive relationships with the 'Chinese overseas' there than it was in pre-war Southeast Asia. The anti-insurrectionist attitude by the Japanese persisted throughout their rule and intensified in the late I920s, when Communist agitation spread and might have linked up with the native Taiwanese opposition and workers' protests. These were at their high point at the time. The Chinese General Association applied for help several times, but the only support provided was by a delegate of the so-called Beiyang government in Beijing, who helped build up its organisation in I926 (Wu I991: 49; $\mathrm{Xu}$ I992: II-I2; Xu I993: 67-69, 7I-73). Afterwards, from I928, correspondence with the Nationalist government in Nanjing was conducted, but to little effect. First, in I928, Nanjing held off a request for the establishment of a Chinese consulate in Taiwan, and subsequently, in I929, it refused to follow up on a request for help with the establishment of educational facilities for migrants' children, allegedly because the bureaus for the implementation of Chinese overseas policies had not yet been fully established (Xu I993: 76). When in 1931, the Consulate was finally there after a struggle of five years, the quick outbreak of hostilities and the subsequent occupation of Manchuria compromised any smooth collaboration between the Taiwanese migrant organisations and the Nanjing government. In the course of the I930s, the situation would only become worse. Despite the reinstalment in I929 of measures by the Nationalist government to encourage Chinese overseas investment back in China, efforts by the Chinese overseas in Taiwan to invest in China were stranded, at least in part because political suspicions could easily be mobilised against them. This happened to Gao Minghong's business venture in Fuzhou in the early I930s, after 
he had stepped down as chairman of the Chinese General Association (Xu I992: 32-38; Xu I995).

\section{Support from the Taiwanese opposition}

The main support for the migrants' protests came from inside Taiwan. Just like in the case of their potential for domestic mobilisation, this support was discursively connected to their status as Chinese overseas. The Chinese sojourner discourse was productively promoted by Jiang Weishui, one of the most prominent leaders of the Taiwanese opposition movement, but was also prominent in the public media (Wu I99I: 48). The opposition had organised itself in I92I under the Taiwan Cultural Association (Taiwan Wenhua Xiehui), the establishment of which in itself was the clearest sign of the enlivening of the Taiwanese public space from the beginning of the I920s (Wu I991: 47-48, 52-54, 56-57). Its most conspicuous political instrument was the yearly submission of a petition to the colonial government, which requested full citizenship rights for the native Taiwanese population; it lasted for fourteen years (I92I-I934) and was known as the Petition Movement. Jiang thought that Taiwanese society as a whole should serve as a bridge between China and Japan. In the familial ideology that he used, Japan was the fatherland and China the motherland of the Taiwanese ${ }^{4}(\mathrm{Xu}$ I99Ib: I20, n. I78). In this sense, all Taiwanese could be identified as Chinese overseas and share with them the potential of mediating between Chinese and Japanese interests (Itō 2005: I72-I73). In addition to this, the South Chinese coastal provinces had a growing expatriate Taiwanese population which was also involved in this scheme. The Taiwanese could play a special role not only because of Taiwan's strategic location but also because of their gradual adaptation to their Japanese colonisers. They did play an increasing role as representatives of Japanese interests in South China and Southeast Asia during the colonial period, to which was added a similar role in Manchuria after its occupation by Japan in I93I (Gotō 2004).

This form of mobilisation was remarkable, also because this was about the last thing the Japanese colonials envisaged when they decided to treat the migrants from mainland China as a species of Chinese overseas. In fact, when an alliance between the Taiwanese opposition parties and the migrants' organisations came up, the much-feared combination of an ethnic alliance of mainland Chinese migrants and native Taiwanese on the one hand and Communist influence on the other could be suspected. The Japanese retaliated with intense police action (Wu r991: 53, 56-57).

Unfortunately, with the present state of research there is no way of knowing precisely which political identifications the Chinese overseas 
in Taiwan made (see note I). Recent migrants, such as those in Taiwan, are usually supposed to have identified most easily with their Chinese background, if only because they were expected to return home and often had no intention of settling in the host country. But even among these, one may doubt whether a full national Chinese consciousness had matured at all (Duara I997), especially in cases when they developed an ambition to settle abroad. This was stronger in Taiwan: because of its history of migration from the mainland, it was natural to identify with the native population and - given the political situation in Taiwan - less with the newly emerging Chinese nation and very little with the colonial elite (Wang I98I; Suryadinata I98I). It seems quite probable that many among the migrants simply ignored the political pressures upon them as much as their immediate environment allowed them and assimilated into the local society just as their predecessors had done for centuries.

\section{The results of migrant action}

The results of migrants' actions were meagre. Equal status with Taiwanese citizens - or something even approaching - was out of the question. In the field of education, virtually nothing was achieved. The Chinese General Association managed to take over several of the tasks of the hoko system and abolish the special fee for migrants, but failed to achieve anything in the sense of liberalising migration or abolishing the Nanguo Company and taking over its functions. The establishment of a Chinese Consular network was achieved in I93I, after five years of struggle, but only just before the Japanese invasion of Manchuria crippled its efficacy. The results of the strikes were meagre (Wu I991: 67-68), and the degree of participation in workers' organisations remained stagnant at seven per cent even when they were most active (Wu I991: 54). One might argue that these are indications of the weakness of the migrants' organisations. One author pleads for their significance, partly on the basis of Gao Minghong's business venture in China: the Chinese General Association helped him out in his lawsuit against his adversaries in Fuzhou (Xu I995: 77-8I). It should be noted, however, that there was a notoriously strong representation of Taiwanese interests by the Japanese consulates on the mainland, which may have helped at least as much.

The results of migrant action may appear slight but should be weighed against the heaviness of Japanese repression. The split into two parts of the Taiwan Cultural Association, after it began to lean to the left in the late I920s, didn't help to invigorate the migrants' main ally in Taiwan, let alone the position of the migrants themselves. The opposition died down in I93I-I934, and the Petition Movement, which 
had been the main symbol of Taiwanese opposition to colonial rule, ended in I934. The General Chinese Association followed suit in I937, after the second Sino-Japanese War had begun and the repatriation of migrants occurred on a large scale. With the war a new situation came into being in which the Chinese General Association was reorganised and, in I940, the Nanguo Company was replaced by another staterelated enterprise (Wu I991: I6, I50; Xu 1997). The debates on the function and status of migrant workers returned in the late I930s, however, and underlined the continued importance of labour migration from mainland China for the colonial state in Taiwan (Song 1937, I943).

\section{Conclusion}

Being legal does not differ from being illegal in its consequences for the migrants' position in society as long as legal status is based on the assumption that the migrants' sojourn is temporary. This is because an illegal status similarly implies the temporality of the migrants' sojourn, and this temporality may be said to be one of the core elements of both statuses. The fact that in important respects the mainland Chinese migrants were not really foreigners, combined with the enmity between their home and destination countries, meant that an illegal status would not have sufficed to keep them in the position of temporary workers: assimilation was relatively easy and fear of penetration by insurgents could easily be justified. In the Taiwanese case, therefore, strict regulation was the obvious solution, whereas in other cases a deficient regulation may work better. The important thing to note, however, is that both arrangements work to the same purpose: i.e. the profitable exploitation of migrant labour. For this reason, the Taiwanese case of legal migration helps us to understand the workings of its illegal counterparts elsewhere, and thereby also helps to conceptualise cross-border movements of people as an instance of why 'state categories often fail to capture the very phenomena they manifestly aim to order'.

\section{Notes}

I This chapter is based mainly on the writings of the Taiwanese historians Wu Wenxing and $\mathrm{Xu}$ Xueji, published during I988-I997. Some information is also taken from popular historical overviews by Chinese historians, such as Tang Cimei (2002), who devotes several sections to the Taiwan huaqiao. Wu focuses on the period I895-1937 and describes in great detail the formation of colonial Taiwan's migration regime, the migrants' social and regional backgrounds, their living conditions and professions, and their organisations and socio-political activity. $\mathrm{Xu}$ has intended to supplement 
Wu's work by including the relationships between the migrants' organisations and the successive mainland Chinese governments, and by going much deeper into the war period and the late I940s, when the migrants' political attitudes during the war had to be accounted for (Xu I99Ia). Both writers emphasise the difficulties encountered by the migrants under the repressive Japanese colonial rule, and take their loyalty to the mainland Chinese governments for granted. Their writings are based on policy reports written by Taiwanese and Japanese academics around I940 (from which the author has also made use), local gazetteers, journals, memorial publications and official documents in the colonial archives. Xu pleaded for collecting and making more extensive use of locally produced literature in mainland China and interviews with descendants of the migrants, in order to get an insight into their individual lives. She made a start with this herself (Xu I991a: 44), but much more can still be done here. At the moment of writing, a project has just begun by Chen Xiaochong (Xiamen University) to this purpose. Wang Xuexi (Taiwan Academia Historica) intends to begin the translation into Chinese of the documents relating to the Taiwan huaqiao in the colonial archives in the course of 2012.

2 On migration from mainland China during this period, see Li in this volume.

3 On the monopolising of migrant labour recruitment in our times, see Li in this volume.

4 This may be considered the positive imagery as compared to the negative imagery famously used by Wu Zholiu, which portrays Taiwan as being an "Asian orphan" with no parents at all. See Wu (2006). 


\title{
10 'Playing Edge Ball'
}

\section{Transnational Migration Brokerage in China}

\author{
Li Minghuan
}

In Chinese, 'playing edge ball' is a popular saying meaning an activity intended to challenge the existing rules and avoid punishment. Originally, 'edge ball' was a term used in table tennis. If the on-coming ball hit only the edge of the tabletop, it would be almost impossible for the receiver to return the ball; thus, the player who successfully hit the edge ball would win the point. It is a great challenge to both hit and receive an edge ball. Therefore the term 'playing edge ball' is often used to connote people who try to gain profit at the edge of the law or regulation while avoiding punishment. In today's China, the transnational migration mechanism is just like a field where the relevant people play edge ball on purpose.

The current trend for emigration from mainland China to the developed world has attracted the attention of Western scholars. Relevant studies have focused on motivation and social networks as well as criminal trafficking and smuggling (Kwong 1997; Smith 1997; Chin 1999; Skeldon 2000; Nyiri \& Saveliev 2002; Liang \& Morooka 2004; Pieke, Nyiri, Thuno \& Ceccagno 2004). However, little has been written in detail about how the Chinese authorities manage ongoing emigration flows. One paper, written by Biao Xiang, focused on exit control by Chinese authorities (Xiang 2003). Although his general systematic review is enlightening, the author does not detail how illegal labour export agencies are able to function successfully and continually while the Chinese government has been trying to exercise control and strictly regulate these agencies.

This paper focuses on the emergence and development of emigration brokerage and explores the trends of current Chinese emigration from perspectives that are relatively less investigated. My contribution proposes to trace the historical trajectory as well as the function of emigration in weaving migration networks, chronologically. First, it will trace the early emergence of the transnational migrant brokerage from the late Qing Dynasty to the early period of the Republic of China. The contrasting social memories of this group of people will be noted. The 
second period covers the I950 to the I970s as a special model of transnational labour migration under the government's comprehensive umbrella. The important part is the third, which is to study how emigration brokerage has re-emerged and functioned during the last three decades. I advance that brokerage is a key node functioning between the state and the individual and that it therefore becomes an indispensable agency in pushing and expanding the trend of transnational emigration. The concluding section notes how transnational brokerage has functioned between legal and illegal approaches and how it has acquired contradicting social images.

\section{Emergence of the Transnational Labour Brokers: A Byproduct of the Authorities' Migration Policy (from the Late Qing to the Early Republic Period)}

Transnational labour brokers are not new in China. Although there is a dearth of actual transnational labour broker records, many documents concerning migrant workers have touched upon the subject to some degree. The emergence of these brokers was a byproduct of the institutional barriers to migration.

Chinese migration to the South Sea - today's Southeast Asia - is a process that began long before the national border was set up. It was in the seventeenth century, however, that historical records started to report on how Chinese people were shipped abroad in groups to work. After the first Opium War (the first Anglo-Chinese War, I839-1842), the colonial expansion in China entailed bringing harbour cities along the south coast of China - such as Xiamen (Amoy, an important harbour city of Fujian), Shantou (Swatow) and Guangzhou (Canton) - into the early colonial globalisation process. The exportation of a significant number of Chinese coolies to meet the demand for cheap labour in newly developing areas overseas increased at the beginning of the nineteenth century and reached its peak in the mid-nineteenth century. At that time, worldwide efforts to abolish slavery had given rise to an indentured labour system.

The regime that dominated China in the nineteenth century was the Qing authority, which maintained a negative policy towards emigration, not only to control the labour force but also due to fears of military resistance from overseas. In the early decades of the Qing Dynasty, the authorities meted out tough punishment for any emigration activity. In the eighteenth century, when the Qing had consolidated its power, the relevant tough punishments gradually came to be maintained only on paper and not in practice. As Western power became a new challenge, labour recruitment for working abroad emerged once again. 
In the nineteenth century, China was a country rich in human resources and thus one of the leading countries sending indentured labourers abroad. It is worth noting that one result of Western influence in China at the time was a social evil in the form of the coolie trade; thus in southern China, the first group of Chinese labour brokers were involved in trade. The term 'coolie trade' is negative and connotes recruiting indentured labourers for the plantations or mines abroad for owners who were often Western colonists.

The first record of Chinese migrant labourers going to Malaya was from I785, when dozens of Chinese workers were recruited by the British Indies Company in Guangzhou and sent to work in Malaya. Since then, more relevant records are available, although the Qing authority still maintained official legal punishment for emigration. In I805 and again in I820, two cases are documented of a British company engaging in the undisguised recruitment of Chinese labourers to work abroad. The recruiters escaped punishment simply by bribing the relevant Qing officials (Yuan 2002: 22-23). However, from records located outside China, it is apparent that there was widespread famine in south China, which drove thousands of Chinese people each year to leave the country and to make their living in Singapore, Kalimantan, Penang and other areas under colonial development (Barth 1964). Soon, the cheap and lucrative Chinese labour resource became an important 'commodity' traded and was bargained by both Western and Qing authorities.

In I860, after losing the Second Opium War (1856-1860), the Qing regime was forced to sign a new treaty with the British in which the latter was given the freedom to recruit labourers in China. Following this example, new treaties were signed between the Qing government and France (I86o), Holland (I863) and the United States (I868), all of which included a similar clause. More precisely, by the late 1860 s, all Western powers had the right to recruit labourers in China.

Subsequently, Western traders established labour agencies in Xiamen, Shantou, Guangzhou and other southern harbour cities, one by one. The earliest labour brokerage for colonial industries abroad was carried out behind the facade of a Western foreign trading firm or their representative agencies set up in China. Inasmuch as the majority of potential coolie resources were in rural areas, the Chinese brokers who were familiar with the local situation and could speak the dialect were indispensable for the functioning of the foreign recruitment agencies. As with the materialisation of the labour market in China, commercial labour brokers became overt businesses. In Chinese, the earliest labour brokers were usually called by names such as ketou (head of guests), shuike (guest coming by water), ${ }^{\mathrm{I}}$ baotou (labour contractor), 
zhuzaitou (head of piglet) or renkou fanzi (trader of labourers) - the last two being very negative.

By the mid-nineteenth century, Chinese labour brokers could be roughly divided into two groups. One was composed of the earlier Chinese indentured coolies whose contracts had expired and who had settled abroad. These men were adopted and sent back to China to recruit new coolies and bring them back for their employers who were, in general, Western planters or mine owners. The brokers in this group were often called ketou or shuike. ${ }^{2}$ The second group was composed of Chinese in China's provincial areas. They were directly or indirectly employed by the Western agencies that had been set up - illicitly or openly - in China. Walking around the countryside, these brokers attempted to induce parents to send their sons abroad or potential adults to sign a contract to work abroad. Some brokers earned high profits from recruiting labourers.

A study shows that, from the 1840 os to the 1850 s, recruiting a Chinese coolie normally cost the broker eight Chinese dollars, given to the coolie's family as a 'family allowance'. However, the broker could receive about too Chinese dollars when 'recruiting' one 'healthy coolie' to the relevant foreign agent (Chen 1999: 59). The profits earned for recruiting females was even higher. ${ }^{3}$ For instance, Xieyitang, a Chinese association in name but functioning as a labour agency, had earned 200,000 Chinese dollars as a result of recruiting 6,000 Chinese females in Guangzhou and selling them to go to San Francisco. It was reported that the cost of recruiting one female labourer in Guangzhou was about 50 dollars but the price of 'selling one Chinese female in San Francisco' was as high as I,000 dollars (Liu I981: I23).

Most coolies, however, were deeply disappointed after arriving in their destination. Their lives in either Western colonialist-owned plantations or mines were full of tears. Only a few could realise their dreams of returning home with some money. Moreover, 'it seems reasonable to assume that before the end of the nineteenth century, one of every four coolies on Sumatra's east coast died before having served his or her contracted period' (Breman I989: 59). The situation of Chinese coolies working to reclaim other tropical jungles cannot be expected to have been better.

Then, a striking contradiction occurred. On the one hand, once the news spread in China of the terrible conditions of indentured labour abroad, fewer labourers could be recruited of their own accord. On the other hand, the profits of commercial labour brokerage were so huge that brokers wishing to recruit more labourers resorted to using any means at their disposal - thus there were increasing reports of fraud and kidnapping by brokers. 
In Xiamen (a city in Fujian), the earliest document on labour emigration was recorded in $\mathrm{I} 620$ when I,400 people were shipped from Xiamen harbour to the Dutch East Indies, most of whom were economic emigrants (XMMYZ I998: 26I). In the nineteenth century, records on the coolie trade show that Xiamen was an active transport harbour. For instance, according to an incomplete account, the number of coolies exported from Xiamen to America and Australia reached 5,69I in I852; and in the first three months of $1853,3,197$ coolies were shipped to the two continents (Wu I988: 42-43). The number of Chinese coolies who were shipped from Xiamen to Southeast Asia was even higher. A study reported that approximately 3.7 million labourers were shipped from Xiamen to Southeast Asia in the nineteenth century (XMMYZ I998: 26I-262), meaning that more than one-third of exported labourers who left for Southeast Asia departed from Xiamen harbour. ${ }^{4}$

In the early Ig6os, a group of researchers of Xiamen University interviewed dozens of coolies returning from Southeast Asia. According to the published materials, approximately 29 of the returned coolies' life stories could be systemised. They were recruited in Xiamen and sent to Cuba in the mid-nineteenth century. Among them, only five were willingly recruited as indentured workers, as eighty percent claimed that they had been kidnapped or tricked. The relevant Chinese language records of the time sharply criticised the brokers as selfish, guileful, gainful, marblehearted and even criminal. ${ }^{5}$ Protest movements against criminal brokers were occasionally reported during the midnineteenth century in Xiamen and other harbour cites of south China.

How the migration policy had been put in practice can be explored from the Qing authority's attitude towards the protest movement. The following case is a telling example. On 2I November I852, a group of angry Xiamen residents seized Shen, a labour broker employed by the British Heji Firm, who was found to be a criminal kidnapper and was sent to the yamun (the local authority) for punishment. After hearing the news, Siam, Shen's boss and the head of Heji Firm, rushed to yamun and forced the local officials to release the detainee. That evening, Siam rushed to yamun again after hearing that another of his Chinese employees was detained because of kidnapping. His assistants fought with the yamun guards, and finally Siam was able to free the detainees and protect his firm. The news provoked all the shopkeepers of Xiamen to go on strike the next day. They remonstrated against cruelty to Chinese coolies and requested punishment for those criminal brokers and called for a halt to all human trade in China. On 24 November, a demonstration by I,500 Xiamen people was held in front of the British Heji Firm. Siam and his peers immediately asked British soldiers who were serving in a warship docked in Xiamen to suppress the demonstration by firing on the masses. During the process, the 
Qing government not only acquiesced to this but also expressed its gratitude to the British army for pacifying the public (Yuan 2002: 25-26).

Since the Qing authority in fact provided great freedom to the Westerners to recruit the Chinese labourers, more labour brokers worked actively and developed transnational migration networks. Moreover, the indentured labour exportation merged with free economic migration and, therefore, provided two contradicting faces to the labour brokers.

Since the early nineteenth century, a widely known phenomenon was that some hostels in harbour cities like Xiamen actually played the role of middlemen by sending people abroad. Normally the owners or the owners' assistants were the focus of a specific network. They often built up their business through their ties of shared provenance. They had contacts with people in the rural areas where they were raised, and they also had contacts with their countrymen abroad. These hostels would arrange a 'package migration service' for people who came to ask for help or for people who were recruited. The 'package migration service' included providing the necessary certificates, tickets, the contact addresses at the destination and, if necessary, a loan for travel. Sometimes, the potential migrants had to stay in the hostel for months waiting for the arrangement.

The service fee charged for a package migration was rather high. For instance, in the I930s, arranging for one person to emigrate from China to Europe would have cost about five hundred Chinese dollars. By contrast, three Chinese dollars at the time could buy one dan of rice (about $50 \mathrm{~kg}$ ). Although the fee was high, some of my interviewees, who were still alive in the I980s, gave a reasonable assessment of the brokers. According to them, "we would not be able to be in Europe without their help' or 'they were experienced persons and we completely relied on their support'. 6

Other comments can be drawn from my recent research on returned Chinese in Xiamen. Some interviewees mentioned how their parents were brought over by ketou to Southeast Asia in the early twentieth century. I noted that they were not critical of the brokerage but also gave positive comments such as the comments quoted above. Some appreciated their parents' lives after becoming free in Southeast Asia. One interviewee told me that he heard from his father that he had had to work for five years to repay his debt to the ketou. While asked what his father thought about such a big fee charged by the ketou, who was his father's cousin, the interviewee told me that while his father was alive, he always paid his respect to his cousin. 'My father could not go to Indonesia without his cousin's help,' the interviewee said.

This brief overview of the early history of brokers in China highlights several points. First, the corrupt late Qing authorities did not take 
serious action to protect the Chinese abroad, particularly exported labourers. Second, the labourers often moved in and out of China through unofficial channels. Thousands of private labour brokers formed the nodes of an interwoven transnational network. These private brokers had two opposing images: on the one hand they were fraudulent and criminal, but on the other hand they were reliable and helpful. What were the reasons for this contradiction?

First, the purpose of labour brokerage is to make profits by channelling human resources internationally. Their effort is to generally play edge ball, since the relevant migration laws/regulations - either for sending or receiving - are an obstacle they have to work around. For those labourers who wanted to make a fortune abroad but were short of the necessary documents and connections, a package deal provided by brokers was regarded as helpful support. Comments about brokers depended to a great degree on the social results of the migration process. More precisely, regardless of whether channelled people had been cheated by a broker or not, and regardless of how high the fee had been, those who survived the hardship and started a new life in the settled destination were not going to complain about the brokers, and some were even grateful to them.

This brief study of the history of how labour brokers functioned between the individual and the state prepares us for a more detailed study of the current transnational migration trend.

\section{Under the PRC Government's Comprehensive Umbrella: Working Abroad on the National Project-Based Approach (1950s-1970s)}

Following the establishment of the People's Republic of China (PRC), the tradition of emigration abroad was interrupted and even condemned as a counterrevolutionary deed, particularly during the period of the so-called Cultural Revolution (I966-1976). At that time, few people were able to obtain permission to go abroad for family reunification; thus, the only official possibility of working abroad was via a national project, which often seemed to be a comprehensive political task.

During the Maoist period, China carried out a series of free projects to aid friendly nations. The workers chosen for these projects were selected on the basis of their political loyalty first, and their skills and working attitude second. Often they were sent to other developing countries that were friendly to China, such as Albania or Tanzania. The workers were normally called honorary volunteers. The selection and transnational working processes were highly institutionalised. During the entire period of working in a destination state, the labourers not only worked in groups but also lived within a certain area under the full 
supervision of the Chinese diplomatic authority. Their income was maintained at the level of their peers in China, except that they had some foreign currency as an extra allowance. In general, to work abroad for China's projects was part of the government's assignment. How long the workers worked abroad was also decided by the relevant authority. The workers usually worked abroad for anywhere between one to three years, but some worked for longer than five years. Among those who refused to return to China, a few were condemned as detestable betrayers. They were considered migrant workers in a very specific category under the comprehensive umbrella of the Chinese government.

Since the end of the Cultural Revolution at the end of the r970s, however, the country's foreign policies were reformed, and the Chinese projects rendering free economic assistance to likeminded countries were gradually replaced by foreign economic cooperation programmes based on mutual benefit. Thus, the pursuit of commercial profits was no longer taboo. Gradually, a few labour agencies with limited authority were established with special permission.

Once again, Xiamen city in Fujian Province serves as an example. In I977, the Xiamen municipality set up a Foreign Aid Office. The main task of the office was to organise qualified technicians or skilled workers to work for China's foreign aid programmes. Although at the very beginning, the relevant 'volunteers' were selected by existing employers rather than by open recruitment, this step marked the beginning of a meaningful transition from the comprehensive job assignment system. By the end of the I970s, when commercial labour exportation projects between China and foreign companies had been developed, more workers were needed to work abroad. In June i980, under a reformed foreign policy, the Xiamen Foreign Construction Company was established and took over the task of recruiting persons to work abroad. The company was still affiliated with the Foreign Economic Cooperation Office of the Xiamen municipality and had to deal with labour exportation under a special authority issued by the latter. Nevertheless, the establishment of this company marked a turning point, since a new institution albeit a semi-governmental institution at the time - started to take charge of labour recruitment. Then, in I984, the Xiamen Foreign Construction Company officially ended its affiliation with the Xiamen municipality and became an independent corporate body, renaming itself the Xiamen International Economic and Technical Cooperation Company (XIETC Company). Its business was still mainly composed of recruiting labourers for foreign contracts.

In Xiamen during the late I970s and the early I980s, the majority of people recruited to work abroad were sailors. Most worked for international shipping companies whose general offices were in Hong Kong. 
Until the end of the I980s, the XIETC Company was the only company authorised by the Xiamen municipality to engage in labour recruitment for formal exportation. In the early I990s, although more companies joined in the business, the XIETC Company kept its number one position as a recruitment institution until the mid-I99os and made huge profits. According to its public reports of labour exportation, total revenue over the period I98I to I995 was approximately US\$ I6I million and net profit reached US\$ 30 million (XMMYZ i998: 272).

The profits came from the XIETC Company's monopoly on the market. Since the early i99os, however, the company has had competitors. When China started its transition from a planned economy to a market economy, more companies attempted to grab the potential profits by becoming involved in the labour recruitment business. Between 1992 and I995, at least five new companies obtained permission to engage in labour recruitment, and all functioned actively in labour exportation. Or to put it differently, it was labour exportation that pushed the re-emergence of labour brokerage. Soon, the business was dominated by the private agencies rather than state-owned ones. The reasons for this are explored here following two case studies.

\section{Functioning Illegally but Licitly: Reemergence of the Private Transnational Migration Brokerage}

In the coastal area of Fujian, efforts by ordinary people to emigrate reemerged even before an open door policy had been fully put into practice. In the early I970s, before the Cultural Revolution came to an end, the Chinese government enacted a policy for those who had returned to China from overseas. The family members of the returnees were granted the right to go abroad as long as they could produce the necessary documents. This emigration permission was severely restricted, but the possibility was there. In the Fujian area, some people with relatives who were settled in Hong Kong, Macao or other places quickly took advantage of the opportunity to emigrate.

Following the start of the reform movement at the end of the I970s, strict regulations on regularised emigration were proclaimed and implemented by the PRC government. The principle behind the relevant regulation was to give the 'green light' for emigration to those who were returned migrants and those who could show the necessary documents for a family reunion issued by the relevant authorities of the destination state. The people who migrated abroad during the first years after the end of the Cultural Revolution were therefore basically 'brought out' by relatives who had already settled abroad. 
As China had just opened its doors to emigration applicants, and since most applicants were not familiar with the formalities involved, most applications were arranged by their relatives or friends who were already living abroad. Of the few who were able to secure permission to emigrate, some obtained permanent residency immediately after their arrival in the destination state, some were granted work permits to settle down, while others stopped in Hong Kong where there was plenty of opportunities to work and the income level was much higher than in mainland China. As a result, the reports sent back from the first wave of emigrants were exciting and encouraged more to follow suit. Only a small percentage of potential migrants, however, could meet the selective requests of the destination states. Many needed to find various forms of 'help'.

From the perspective of 'helping' transnational migration, brokers basically functioned along two avenues. One was to send people in groups, and the other was to send individuals. The case of channelling people to work in Israel is representative of the former, and the latter was the case for people travelling to North America. Today, who acts as a migration broker? How have they functioned illegally but licitly when institutional barriers prevent cross-border migration? The following are cases based on my field research in some well-known out-migration villages of Fujian Province.

\section{Sending Migrant Workers to Israel}

The PRC and Israel held opposing political standpoints during the Cold War period. Since the Korean War broke out and until the mid-I980s, during a period of more than three decades, China was strongly against Zionism and refused to have any direct contact with the state of Israel. However, from the mid-I980s, when China unveiled its 'open door policy' and progress was being made on peace in the Middle East, the PRC and Israel stealthily restarted their diplomatic contact. Finally, on 24 January I992, China and Israel officially established diplomatic relations.

The working environment of Israel needs to be briefly noted. Since the late I980s, a series of strikes, disruptions and terrorist attacks carried out by Palestinians inside Israel had resulted in the progressive erosion of the recruitment of Palestinian workers. Finally, in February I993, the Israeli government decided to close Gaza and the West Bank. The unavailability of Palestinian workers forced Israeli employers to search for alternative sources of inexpensive but reliable labour (Borowski \& Yanay I997; Amir 2002; Kemp \& Raijman 2004; Kalir 20IO). It is worth noting that by this time, China and Israel had 
achieved amicable relations at the state level. The first Chinese labour exportation contract between Israel and China was signed in I992, before official diplomatic relations had been established. At the state level, this was the starting point of China's labour exportation to Israel (see Kalir in this volume).

Although Fujian has a long history of international migration as described above, before the mid-I990s, no members of the local Fujian community had had contact with the Middle East. Due to formal and informal brokerage, Israel has become one of the new destination states for Fujian migrant workers.

An interview with a local government official provided the following information. In the early I990s, the Jian Long Company, one of the first companies authorised to send contract labour abroad, came to TA County (fictitious name) to recruit villagers to do plastering work in Israel. It was said that Jian Long first tried to recruit workers in the city of Xiamen but failed. Urban youths were not interested in going to Israel, which was regarded as an enemy state with a bad reputation. One director of the Jian Long Company happened to be a native of the TT village (fictitious name) in TA County, which is located in a suburb of Xiamen. Knowing that his fellow villagers had a tradition in plastering, the director went to recruit workers in his hometown area. Most villagers were poorly educated and knew nothing about the outside world. What they were attracted to was the unbelievably high wage promised by the company. Soon many villagers went to sign up, and this was how the labour migration to Israel started in TA County.

For those who want to work in Israel, however, recruitment is expensive. Various companies charge a range of recruitment fees. According to the local cadre mentioned above, officially the recruitment fee to work in Israel cannot be more than 30,000 RMB including airfare. This is higher than what is allowed under Israel's Employment Service Law in 2004, which allows for direct expenses and a surcharge of US\$ 900 (Kruger 2005), equal to 7,200 Chinese yuan. ${ }^{7}$ However, my field research data shows that the migrant workers had to pay much higher fees. In the mid-I990s, fees were about 50,000 Chinese yuan, and by 2004 these had increased to between 70,000 and 90,000 Chinese yuan. Furthermore, after July 2005, when the minimum wage of a migrant construction worker in Israel increased from US\$ $2.90-U S$ $\$ 3.50$ to US\$ 4.25 per hour, the recruitment fee reached as high as I50,000 Chinese yuan. According to information I have accumulated over the years, the recruitment fee floats with the wage level in the destination labour market. The underlying regulation here, or the tacit standard by usage, is that on average the migrant workers had to spend the equivalent of two years' salary to cover their recruitment fee (see also Kalir in this volume). 
Although the recruitment fee is very high, migrants believe that they can repay the debt within one or two years, if they work hard and can get call-back pay by working overtime. Then the wages after paying their debt would be their 'real income'. In 2005, I saw an advertisement recruiting migrant workers for Israel on a street in TA County. It highlighted a monthly wage of 8,000 Chinese yuan for a construction worker in Israel with opportunities to earn even more through overtime. In Fujian, on average, the rural household annual income was about 2,048 Chinese yuan in 1995, which increased to 3,734 Chinese yuan in 2004 (NBS China). Although the economic situation in Fujian is improving, when comparing incomes in Fujian and Israel, the rising income level in China has little dampening effect on the potential benefit of working in Israel.

Therefore, to a certain degree, the first group went to Israel almost by accident, although the income gap between a Fujian village and Israel was the most influential factor. Many were not intending to go to Israel before they were recruited. Only when a certain brokerage company provided the opportunity to work in Israel did a migration wave become initiated in an institutionalised way.

\section{Channelling Villagers to North America}

The function of brokering potential migrants to North America shows a different picture. TJ village (fictitious name), located on the coast of Fujian Province at the outfall of the Min River, is one of my fieldwork areas. Nobody knows how long ago it was that local young men started to enjoy a good name for being sailors. After the establishment of the modern sea transportation business, many local youths were employed by foreign shipping companies. At that time, New York was both an important international seaport and a paradise for adventurers. Often when ships stopped at New York, some seamen, who were tired of the seafaring life, would jump ship to make their living ashore. Young sailors from the TJ Region did this too, and so people of the TJ Region started to take root in the United States. This continued for decades in the first half of the twentieth century.

In the mid-I970s, as mentioned above, Chinese who returned from overseas and their families received permission to travel abroad if they could provide the required documents. Permission was severely restricted, but emigration had become possible again; TJ residents with relatives in the US seized the opportunity. Brokerage re-emerged when these potential migrants needed professional help to prepare their documents. If the relevant documents were fragmentary or incomplete, the brokers would help to obtain acceptable documentation. Some-times, if 
potential migrants did not hold the qualified documents, brokers would help to arrange a zigzagging travelling path to evade the border control of the destination state. All of these measures are beyond the ability of Chinese natives, so they are forced to pay the fees. The more complicated the case is, the higher the charges. Again, what the Chinese cared most about was whether the dream of transnational migration could be realised, rather than whether the migration mechanism was legal or not. The following is a telling case in point.

In June of 2005, a series of reports appeared in all Chinese media in the United States and attracted the close attention of Chinese immigrants and their relatives in mainland China. It was about a woman on trial in New York known as Ping Sister who was accused of being a big snakehead who had made US\$ 40 million from smuggling Chinese into the United States. Moreover, she was accused of being involved in several tragedies where dozens of stowaways died on their way to the US. $^{8}$ Who is this Ping Sister and how did she make such a huge profit from smuggling people?

Ping Sister was born into a peasant's family in the TJ Region. Her full name is Cheng Chui Ping. All the people who know her or who want to contact her, however, call her Ping Sister. She only received a primary school education for a few years during her childhood. Together with her husband, she emigrated to Hong Kong in I974. Then in I981, she found a way to get into New York and settled in Chinatown as an undocumented worker. Nobody knows how she was able to obtain her green card so smoothly after being in the United States for only one year.

In view of the possibilities for making a living in the United States without legal status and the large discrepancy in potential salary, Ping started to 'help' her relatives and friends to emigrate to the United States. At the very beginning, she only received 'rewards' for the arrangements. When it became an open secret that 'it needs money to buy every step of emigration', the brokerage fee settled on the market price. In the TJ Region, the first well-known fee of channelling one person to the United States was US\$ I8,000 in the mid-I980s. In the years that followed, however, the fee skyrocketed. By the end of the I990s, the fee had climbed to between US\$ 40,000 and US\$ 60,000 for one person. When I did my field research in TJ village, I met one woman who had just received her legal documents to migrate to the United States together with two of her children. She had spent a total of US\$ 70,000 to arrange the migration. Seeing how shocked I was by the number, she said it was for 'three people' and therefore can in fact be regarded as rather cheap.

When Ping's business of transnational brokerage was in its initial stages, an important policy issued in the United States gave her 
business strong positive encouragement, and the latent influences cannot be overstated. The implementation of the Immigration Reform and Control Act enabled millions of irregular immigrants to obtain permanent status to live and work in the United States. Among these 'lucky ones' were hundreds of Ping Sister's first 'customers'. When the news spread in Ping's home area, she was highly admired as a local heroine.

Pushed by the news mentioned above, potential emigrants could not wait and wanted to be channelled immediately. Although the exact timing is not clear, in the late I980s Ping started to rent and buy freighters for smuggling people in large groups. In order to carry more stowaways to increase profits, each ship was planned to accommodate hundreds of persons. It was said that the biggest group was composed of more than 500 people on board. Both costs and profits - not to mention the risk of transportation - soared to ever higher levels. In June I993, the world was shocked when about 300 Chinese on board a decrepit freighter, the Golden Venture, made a forced landing on shore in the United States, in the process of which eleven drowned. Although Ping was not the owner of the freighter, she was involved in the affair. Her name was listed at the top of the list of criminal Chinese smugglers. However, she did not stop her business until she was arrested at Hong Kong airport in April 2000.

In July 2003, Ping was delivered to the New York police. Since then, Ping has been brought before the courts many times. During my research in her hometown area in 2005 , the residents were concerned about the trial. On 30 June 2005, Ping's trial was deemed a mistrial because the testimony was deemed to be unacceptable. When the judgment became known, it was said that many Chinese immigrants in New York were elated. According to the report, the popular viewpoint was as follows: 'this 56-year-old Ping Sister is a good migration broker because she helped a lot of her co-villagers realise their dreams of upward mobility. Only in the eyes of the American officials was what she did criminal'. When interviewed, a head of the Fujianese association in New York said: 'Ping Sister enjoys the best reputation among dozens of the snakeheads. She did offend the immigration law of American. But from the perspective of moral she is not criminal. She is innocent'.

In Ping's hometown, I interviewed dozens of the locals, including officials and ordinary people. None of the interviewees regarded Ping Sister as a criminal, although some kept silent on the question. One man told me that Ping gave him a 'special discount' for channelling his son to the United States only because he was her former classmate. 'She is always kind in responding to requests of help,' he said. 'My son could not get into the United States without her help. I could not build this five-story house without my son's money'. When asked whether it is criminal that Ping charged a huge amount of money for emigration, 
most interviewees gave the following kind of response: 'It is reasonable because she needed money to 'buy' the way for us. The money can be earned back so long as the person can get into the United States'. 'All companies charge money for labour exportation. Only those who receive money but do not send the payers to the destination state are regarded as criminals'.

The immigration expert Prof. Kwong of Hunter College in New York once made the following comment: 'we can only say that by choosing to smuggle Chinese as her major business, Ping Sister is a good businesswoman' (translated from Chinese by author). Then Kwong added the following comment: 'no doubt, high compliments from her compatriots cannot erase her criminal activities' (translated by author) (Wang 2005). On I6 March 2006, Ping was condemned to 35 years in prison. For a woman who was in her late 50s, this sentence was equivalent to life imprisonment. When the sentence was handed down, I had already left the village. However, I was informed by phone that her hometown people did not accept it as a reasonable conviction.

Why did local people continue to respect Ping even after she had been sentenced as a criminal? The reasons should be traced to the popular image of the brokers. Emigration brokers, or snakeheads in the words of the official media, can be divided into three categories. At the top is a small group including members like Ping Sister who hold the legal status to stay abroad. Under their management, a considerable amount of money is used to 'pave the way out' - that is, organising and expanding the transnational networks of migration, obtaining necessary documents or facilities for the clients transnationally, and/or bribing the relevant officials both in China and in the destination countries. In the middle, there are active agents who often sit in an officially registered company in the sending area. Normally, these companies are authorised to deal in labour exportation, study abroad, transnational contracted projects and so on. The companies often provide training courses for their clients, which can be broad and may include the language used in the planned destination country, cooking, nursing or basic knowledge of the computer. Other subjects include how to be interviewed, how to prepare the necessary documents and, in some cases, how to apply for legal status when arriving in a country illegally. The clients would expect to get the certificate they need in the name of the company or a certain school, as long as they had paid for it. These are the institutionalised brokers. Then, at the bottom of the brokerage networks are the locals who act individually. Normally they have a connection with the middle group but some may have direct contacts with the big head, such as the co-villagers of Ping Sister. Their mission is to find potential customers and introduce them to the relevant companies or big snakeheads. For each potential migrant the local mediator 
recruits, the company or big head pays the mediator a commission, which can be anywhere between a few thousand to ten thousand Chinese yuan.

Since the late I990s, the relevant authorities in China have repeatedly proclaimed that any activities concerning human smuggling are illegal and have alerted the locals to pursue those involved in these activities. After the Dover tragedy in which 58 Chinese stowaways were found dead in a truck, dozens of snakeheads were arrested and punished, according to reports. Among them were local brokers at the bottom of the brokerage network, because they had direct connections with the victims and could be easily identified. A few were big heads such as Ping Sister, who were hunted down internationally.

The locals usually make comments about transnational migration brokerage from three perspectives. First, they look at whether the broker was competent enough to get the clients to their destination efficiently. Second, they consider whether the journey was safe. Third, they assess whether what the broker had charged was reasonable or not. A local saying goes: it is more difficult to find the right broker than to borrow enough money to pay the brokerage fee. Taking these grassroots principles into account, it is understandable that Ping Sister received high compliments from her co-villagers.

The most attractive aspect of working in developed countries - regardless of its validity - is that you can expect to earn a high income by simply being a hardworking person. For average people who are not qualified to emigrate under the selective system of destination states, the chances of upgrading their fate by emigrating abroad is not possible without the special 'help' provided by the brokers. If the brokers are competent and can make emigration accessible, they are accepted; and if their brokerage business is highly successful, they will be admired to the extent that brokers who have formed an indispensable node for transnational migration are prevalent among average people.

From the brokers' perspective, it is often not easy to define the line between a smuggler (snakehead) and a legal agency dealing with the affairs of going abroad. Paying a fee is an investment for the emigrants, and the broker has to charge a payment for the business. The deals follow invisible market rules. First, the cost depends on the anticipated income in the destination country. For instance, the brokerage fee for going to the United States is always higher than for going to Europe. Second, it depends on how difficult it is to pave the way for migration. The most expensive cost is obtaining official immigration status. If the applicant agrees to go abroad as a contract worker to countries such as Israel or Kuwait, the charge is lower. Third, it depends on the individual status of the applicant. If the applicant is more or less qualified under the selection requirements, the fee would be lower. If the applicant 
needs to be 'trained' to reach the standard, the price rises accordingly. Sometimes, legal agencies channel their clients illegally but undocumented brokers may channel their clients legally. Both have to play edge ball to challenge the migration law, since it is often difficult to match the requests of the receiving state and the quality of the potential migrant labourers.

\section{Concluding Remarks: Illegal but Licit}

International migration lies at the centre of global issues today. Some scholars have correctly pointed out: 'Paradoxically, the [state's] ability to control migration has shrunk as the desire to do so has increased. The reality is that borders are beyond control and little can be done to really cut down on immigration' (Bhagwati 2003: 99). Therefore, 'undocumented migration keeps growing despite control efforts by states and supranational bodies' (Castle 2004: 852).

In China, after three decades of development, a 'transnational migration industry' has formed a network at both the internal and international levels. Due to the contradictions between the migration policies on the books and the reality of labour needs in the relevant destination states, transnational activities of the average people are often considered acceptable (licit) by participants but are illegal in a formal sense at the national level. As a result, the whole process of transnational migration brokerage has been played out between legal and illegal approaches, both in China and the destination states. Though no state (whether sending or receiving migrants) would declare its support for illegal practices, yet in practical terms, states consciously or unconsciously are involved in and encourage such activities.

From the perspective of the sending state, there is no doubt that the Chinese government has made great efforts to stop human smuggling. Severe penalties have been imposed, especially on snakeheads. In the TJ Region, posters and pamphlets can be seen everywhere publicising the government's decision to crack down on human smuggling and educate the villagers not to engage in illegal emigration activities. However, when the successful overseas Chinese return to their hometowns, they would be met with great honour, especially if they have made an investment or donation to the town. In the TJ village, those who have made considerable contributions to local development have been listed in the rolls of fame. Of those listed, more than half were irregular migrants at the start but successfully changed their status afterwards. In another phase of fieldwork in 2005, I was introduced to some honorary returned migrants by the county authority. Among them, I found one whom I knew when he was an undocumented cook 
in a Chinese restaurant in the Netherlands. He worked there for eight years - no vacation, not even weekend leave. Moreover, he did not spend even one penny for himself, as he told me. ${ }^{9}$ Seeing no possibility to change his status, he returned home with the money he had earned in those eight years and invested it in his hometown. After setting up a local business, he was honoured as a representative of the successfully returned migrants. ${ }^{\text {IO }}$ At that point, no one would care about how the person achieved his emigration. As this is indeed the case, the latent information expressed by the end product is in itself significant.

From the perspective of receiving states, all of them have strengthened their official control of immigrants. Most governments wish to accept talented people such as entrepreneurs and professionals, while the vacancies in most labour markets are in the ${ }_{4} \mathrm{D}$ area: difficult, dirty, dangerous and demeaning jobs. What employers want is simply to obtain cheap labourers. However, the relevant authorities often leave irregular workers alone simply because they are the first group to fill the vacancies, which protects the comprehensive social welfare system from corruption. Moreover, in some high-income states, amnesty or legalised movement is on hold now and then. Although the government's purpose of legalisation is to uphold the legal rights of employed irregular immigrants, the hidden information of such an opportunity gives the irregular immigrants reason to hope that their irregular status is temporary and may be changed overnight.

Finally, in the eyes of the migrants and the people concerned, 'being channelled to another country' is not a criminal act but a worthwhile attempt chosen by people who wish to make a fortune abroad but lack the legal entitlement. The most attractive point of working abroad - regardless of its validity - is that you can expect a high income by simply being a hardworking person. What they care about is the end product. As long as migrants return as successful overseas Chinese, all the struggles and concerns about whether the process of migrating was legal or illegal, are erased.

As information, capital and commodities are moving more actively than ever in this period of globalisation, this will surely encourage a greater flow of people. No one can deny this, nor can anybody stop it. Meanwhile, the function of brokerage at the transnational level will remain indispensable. Although it is easy to declare the illegality of some transnational activities, more efforts are needed to explore its longstanding and broad acceptability.

In general, some migrants go abroad via state-bound agencies (most of which are legal but might act illicitly), while others go via private brokers (most of who act illegally but are considered licit by their clients who need their service). Therefore, both legal and illegal migration brokerages are playing edge ball in making profits by channelling people 
abroad. Furthermore, the game has become licit because both sides get what they want: the migrants who expect to earn more than they can in China through transnational migration and the entrepreneurs of the destination state who need cheap labourers to increase their profits. All of them, consciously or unconsciously, work together to challenge migration laws, and therefore all the actors involved in the migration process play the game of edge ball.

\section{Notes}

I Sometimes shuike also traveled between the destination area and the hometown to bring coolies' remittances to the family members that were left behind. But this will not be discussed here.

2 For instance, according to Jan Breman's study, in the plantations on Sumatra's east coast, 'soon after the turn of the century, around five per cent of the workforce was sent home for this purpose. They took cash with them or a cheque, payable by an agent of the Immigration Bureau, and on return to Deli they were given a premium by their employers for each new coolie who came with them' (I989: 55-56).

3 In China, the tradition was that the male adult had the responsibility to support the family. In the period before the Second World War, few women dared to go abroad as the pioneer of the family. An investigation in one out-migration village in the southern Zhejiang Province shows that among the I,309 people who went abroad before 1948 , only eight were women (Wang I985: 4). Chinese females were badly needed, since the Chinese abroad formed what was almost exclusive a single-male society. Therefore the price of 'recruiting' a Chinese female was much higher than recruiting a male.

4 According to figures that are widely accepted among Chinese academics, in the I840s about ten thousand Chinese coolies were shipped to Singapore on average every year (Chen I984: 86). Another statistic revealed that more than ten million Chinese coolies were shipped abroad between the early nineteenth century and the I930s (Peng I980: 3).

5 The following table was obtained and translated from Qiyue Huagong Shi [A history of indentured Chinese workers], written by Wu Fengbin I988: 49-5I. Nanchang: Jiangxi renmin chubanshe.

6 The relevant information was collected from my research on Chinese immigrants in Europe, a project carried out between I995 and I998. See also Li I999: 27-34.

7 Although fluctuating across time of course, I refer here to an exchange rate between US dollar and the Chinese yuan that stands at an approximate ratio of $\mathrm{r}: 8$.

8 The relevant reports are online: http://www.fujianese.cn/news.

9 In the Netherlands, normally the owner of the Chinese restaurant would provide free accommodation to employees if the latter agreed to live in the restaurant.

Io In my paper published in I999, I mentioned my interview with this person in his home village in 1996 , and showed 'what his fellow villagers like to talk about is the visible result: another "rich migrant" has come back' (Li I999: I92-I93). In 2005, nearly ten years after my first interview, I met this person again when he became the representative of the successfully returned migrants. 
Table 10.1 Self-given reasons of becoming indentured workers abroad

\begin{tabular}{|c|c|c|c|c|c|c|}
\hline & Name & Birth place & Occupation & & $\begin{array}{l}\text { Year of } \\
\text { leaving } \\
\text { abroad }\end{array}$ & $\begin{array}{l}\text { Reason for becoming indentured } \\
\text { workers abroad }\end{array}$ \\
\hline 1 & Su A Hai & Tong'an & Fisherman & 32 & 1846 & $\begin{array}{l}\text { Kidnapped when selling fish in } \\
\text { Xiamen }\end{array}$ \\
\hline 2 & Tang Jian & Hui'an & No & 29 & 1847 & $\begin{array}{l}\text { Persuaded to work for a foreign } \\
\text { company but was betrayed }\end{array}$ \\
\hline 3 & Chen Aji & Quanzhou & Peasant & 21 & 1848 & Wanted to work abroad \\
\hline 4 & Ye Tian & Tong'an & Peasant & 20 & 1852 & $\begin{array}{l}\text { Father died and mother remarried; } \\
\text { persuaded to be recruited for a } \\
\text { decent job but was betrayed }\end{array}$ \\
\hline 5 & Guo Zhan & Tong'an & Peddler & 38 & 1852 & $\begin{array}{l}\text { Kidnapped when selling goods } \\
\text { along the street }\end{array}$ \\
\hline 6 & $\begin{array}{l}\text { Chen } \\
\text { Dingxian }\end{array}$ & Zhangzhou & Doctor & 38 & 1852 & $\begin{array}{l}\text { Business failed; convinced that it } \\
\text { would be easy to earn money } \\
\text { abroad }\end{array}$ \\
\hline 7 & $\begin{array}{l}\text { Zhang } \\
\text { Zhao }\end{array}$ & Quanzhou & Peasant & 42 & 1852 & $\begin{array}{l}\text { Quarreled with a brother and was } \\
\text { betrayed by the brother }\end{array}$ \\
\hline 8 & Chen Lin & Tingzhou & Helper & 15 & 1852 & $\begin{array}{l}\text { Wanted to earn more money } \\
\text { abroad }\end{array}$ \\
\hline 9 & Luo Fuan & Yongchun & Cook & 21 & 1852 & Cheated to work on board \\
\hline 10 & Wu Yue & Zhangzhou & Fisherman & 27 & 1853 & $\begin{array}{l}\text { Came with someone to work in } \\
\text { Xiamen but was locked after arrival }\end{array}$ \\
\hline 11 & $\begin{array}{l}\text { Wang } \\
\text { Shuitou }\end{array}$ & Nan'an & Peasant & 44 & 1854 & $\begin{array}{l}\text { Wanted to work abroad because of } \\
\text { poverty }\end{array}$ \\
\hline 12 & $\begin{array}{l}\text { Chen } \\
\text { Wansheng }\end{array}$ & Zhangzhou & Peasant & 22 & 1855 & $\begin{array}{l}\text { Wanted to work abroad because of } \\
\text { poverty }\end{array}$ \\
\hline 13 & Xu Shu & Quanzhou & Fruit seller & 27 & 1855 & $\begin{array}{l}\text { Convinced that it would be easy to } \\
\text { earn money abroad }\end{array}$ \\
\hline 14 & Huang Ji & Jinjiang & Peasant & 21 & 1855 & $\begin{array}{l}\text { Parents died; wanted to find a job } \\
\text { and was persuaded to earn money } \\
\text { abroad }\end{array}$ \\
\hline 15 & $\begin{array}{l}\text { Wang } \\
\text { Ajing }\end{array}$ & Quanzhou & Peasant & 21 & 1855 & $\begin{array}{l}\text { Convinced that wages abroad were } \\
\text { much higher }\end{array}$ \\
\hline 16 & Lin Alu & Jinjiang & Helper & 22 & 1855 & $\begin{array}{l}\text { Cheated to have a job on board but } \\
\text { was betrayed into a snare }\end{array}$ \\
\hline 17 & Guo Fu & Jinjiang & $\begin{array}{l}\text { Owner of a } \\
\text { rice shop }\end{array}$ & 33 & 1855 & $\begin{array}{l}\text { Dared not to return home because } \\
\text { of losing all money in gambling; } \\
\text { then was betrayed by a gambling } \\
\text { partner }\end{array}$ \\
\hline 18 & Lin De & Tong'an & Peasant & 14 & 1857 & $\begin{array}{l}\text { Kidnapped when going to visit an } \\
\text { uncle }\end{array}$ \\
\hline 19 & Zhu Axing & Zhangzhou & Trader & 20 & 1858 & $\begin{array}{l}\text { Betrayed into a snare when having } \\
\text { a dinner with friends on invitation }\end{array}$ \\
\hline 20 & Chen Shui & Xiamen & Sailor & 26 & 1858 & $\begin{array}{l}\text { Accepted an offer to work as a } \\
\text { sailor but was betrayed }\end{array}$ \\
\hline 21 & Chen Qin & Zhangzhou & Soldier & 17 & 1859 & $\begin{array}{l}\text { Kidnapped when returning from } \\
\text { Xiamen to hometown }\end{array}$ \\
\hline 22 & Lin Ayong & Zhangzhou & Student & 17 & 1859 & Kidnapped to Xiamen \\
\hline
\end{tabular}




\begin{tabular}{|c|c|c|c|c|c|c|}
\hline & Name & Birth place & Occupation & & $\begin{array}{l}\text { e Year of } \\
\text { leaving } \\
\text { abroad }\end{array}$ & $\begin{array}{l}\text { Reason for becoming indentured } \\
\text { workers abroad }\end{array}$ \\
\hline 23 & $\begin{array}{l}\text { Huang } \\
\text { Dun }\end{array}$ & Zhangzhou & Peasant & 36 & 1860 & Kidnapped when going to market \\
\hline 24 & Chen Xing & Quanzhou & $\begin{array}{l}\text { Flower } \\
\text { seller }\end{array}$ & 18 & 1863 & $\begin{array}{l}\text { Cheated to work on board for high } \\
\text { wage }\end{array}$ \\
\hline 25 & Shen Sai & Zhangzhou & Peasant & 40 & 1866 & $\begin{array}{l}\text { Cheated to work on board when } \\
\text { escaping from a local turmoil }\end{array}$ \\
\hline 26 & $\begin{array}{l}\text { Chen } \\
\text { Cheng }\end{array}$ & Tong'an & Peasant & 42 & 1869 & $\begin{array}{l}\text { Cheated to work abroad for better } \\
\text { conditions }\end{array}$ \\
\hline 27 & $\begin{array}{l}\text { Chen } \\
\text { Zhen }\end{array}$ & Xiamen & Peddler & 21 & 1869 & $\begin{array}{l}\text { Cheated to have a job abroad but } \\
\text { was sold as a coolie }\end{array}$ \\
\hline 28 & Liu Yingfa & $\begin{array}{l}\text { Jiangxi } \\
\text { Huichang }\end{array}$ & Trader & 36 & 1869 & $\begin{array}{l}\text { Business failed; came to Xiamen in } \\
\text { order to work abroad }\end{array}$ \\
\hline 29 & Li Asan & Quanzhou & Peasant & 21 & 1870 & $\begin{array}{l}\text { Accepted an offer to work on board } \\
\text { but was kidnapped }\end{array}$ \\
\hline
\end{tabular}





\title{
Epilogue
}

\section{Irregular Mobilities and Disjunctive Moralities}

\author{
Hastings Donnan
}

This stimulating set of essays is the result of a long-term comparative project that suggests new ways of conceptualising and studying empirically the key terms of its focus: transnational movement, borders, states and the boundaries of legality and the legitimate. Drawing on the literature from a wide range of disciplines, the contributors invite us to reflect on transnational flows and processes, arguing for an ethnographically grounded perspective and engaging critically with approaches that over-determine the separation between society and the state. At the core of their persuasive critique is a fourfold matrix that maps the cross-cutting relationships among different forms of social regulation (legal, illegal, licit, illicit) and that enables them to focus on activities that, while formally illegal in the eyes of the state, are nevertheless considered broadly acceptable to society more generally or at least to some parts of it. Such 'permissible' illegalities - referred to throughout this volume as 'licit but illegal' and the least studied of the combinations articulated in the matrix - are regarded as morally unobjectionable and are practiced and even expected in certain circumstances not just by 'outlaws' who live beyond the law but by many members of society, including otherwise law-abiding citizens and occasionally even by those responsible for policing such activities. Sometimes these activities recall the apparently inverted moralities played out in gangster movies where crooked cops rub shoulders with honest robbers or where there is 'honour among thieves'. However, they do more than just blur the moral lines between those on different 'sides' of the law. They characterise a world in which the everyday morality that licenses illegality complements and even paradoxically facilitates, as it simultaneously grates against, the legal systems of state and trans-state governance that seek to order human mobility and other global flows. In other words, the contributors argue, activities that are illegal but licit are an elemental and fundamental part of the state and are especially integral to the operation of transnational migration in the various parts of Asia they explore. 
The approach to these issues adopted in this collection thus builds upon and extends key developments in contemporary social theory that have sought to transcend the limitations of a state-centric perspective by, for example, seeing the world from the edges-in and the bottom-up. Its special strength rests on two central elements: a recognition of the state and its territorial and sovereign borders as historical contingency, and a focus on the proliferating regulatory regimes whose contradictions and convergences shape and set limits to movement between states. In the view taken here, states are better understood in terms of process rather than finished product and are generally less coherent in their capacity to regulate people's behaviour than the classic model of the state suggests.

Anthropologists and ethnographers have often been criticised for dealing with the state as little more than an unexamined presence looming in the background of their analyses, a ghostly phantom that defines the rules of the game and frames the actions of those studied. Even those who incorporate the state into their analyses have sometimes found it hard to exorcise the weight of historical social theory that predisposes us to conceptualise the state as being more than the local, an entity that exists over and above society and as something to which local people and local worlds respond. Conceptualised in this way, ethnographic accounts will always be less than the state (cf. Krohn-Hansen \& Nustad 2005: 15). Rejecting as partial a perspective on human mobility that privileges a 'top-down' approach that allocates analytical priority to the state, the contributors here demonstrate the power of ethnography and its still largely untapped potential for illuminating social processes that extend far beyond the 'local'. Yet as the contributors also make clear, consciously advocating a perspective only from below is not by itself an answer, since this obscures how the state, the local and the transnational relate, connect and converge.

They seek instead to probe the insights from understanding how the world is seen and experienced by those on whom their research has chiefly focused: the migrants, traders, cultural brokers, entrepreneurs and state employees whose relationships, responsibilities and individual aspirations coalesce or conflict in ways that promote or impede transnational mobility. As the chapters show, it is the encounters between these individuals at historically specific moments that 'complete' the otherwise unfinished business of the state which, for reasons ranging from the bribery of officials to bureaucratic inefficiency, can rarely fully implement in practice its policies and rules (cf. Heyman \& Smart I999: 2). For this reason, the contributors focus carefully on both local settings and the state, whose mutual entanglements with the transnational generate the particular configurations of illegality and permissiveness that the chapters explore. States as arbiters of law have the power to 
define legality and illegality, but the boundary between these is also shaped by international law, which frames and even contains the reach of the state, as Wong and Suan point out in this volume. Moreover, the boundary between legality and illegality is necessarily enacted in local practice where divergent, if formally unequal, understandings of what is right or just may come into play. In other words, the state is seen in this volume as being just as socially situated as 'the local', and its everyday enactments thus just as amenable to ethnographic analysis (cf. Gupta I995).

It is this interplay between divergent and sometimes convergent forms of justice that shapes the boundary of legality which, while expressed in legal theory, is simultaneously an emergent property of social practice. The case studies presented here demonstrate how people respond to state regulation not with inertia but with a creative resourcefulness that pushes at the boundaries of the possible, even where this might involve transgressing the limits of the law. Everyday forms of survival thus become one way in which the legal boundaries of the state are extended and remade, with licit but illegal practices shaping the regulatory functions of the state and its boundaries as well as being moulded by them. Actions at these margins are thus themselves boundary-making practices that imply an agency beyond that emphasised by those who see such activities principally in terms of state subversion and resistance (Das \& Poole 2004; Wilson \& Donnan 2005).

Just because some illegal practices are locally acceptable - such as some forms of what the state classifies as smuggling - we should not think of them as inevitably subversive of the state, as is sometimes suggested. They may evade state regulation and reduce tax revenue, but they do not necessarily stand against state-formulated forms of justice or deny their legitimacy. They are not necessarily 'anti-state' or 'beyond the state'. Thus Heyman and Smart (1999: 13) see illegality not as the subversive response of a stigmatised group but as a resource available to all, including state agents. The chapters here by Kalir, Verkaaik, Khan \& Rehman and by Ford \& Lyons clearly indicate how this can be the case and recall the situation in parts of West Africa where state agents are so deeply implicated in the growth of unregulated cross-border traffic that such activities cannot be seen in terms of 'society' versus 'the state'. Police and customs officials are so systematically involved in such trade that the distinction between 'us' and 'them' is unclear (Roitman 2004: 202) and the difference between state and non-state agents not easy to sustain (Pattadath \& Moors). Merchants, wholesalers, shopkeepers and truckers all find themselves involved in relationships with various actors who seek to regulate their activities, some of them statesanctioned and others not, just as do the Chinese migrants seeking permits to work in Israel and the Keralan women wishing to work in the 
Gulf states described in this volume (Kalir; Kodoth \& Varghese). The result is not the collapse of state regulation but its fragmentation and dispersal across a proliferation of forms of authority, often with 'legalities' alternative to the state, and amongst which the state takes its place as only one. This seems to take an extreme form in northwest Pakistan where, as Verkaaik, Khan and Rehman describe, the four 'authorising discourses' they identify each have their own distinctive moral languages and legal systems. In such situations of regulatory diffusion, many more people become involved and any revenue that is generated must make its way to the state outside formal legal channels. These multiple regulatory regimes then become a necessary part of the functioning of the state and in symbiosis with it, supplementing the salaries of underpaid state officials, thereby ensuring the continuation of the state itself by generating a source of unofficial income and acting as an informal means of redistributing wealth to local communities. 'Such complicity does not necessarily mean that unregulated traffic is legalised. The state simply offers a legal structure for these activities' while still classifying them as formally illegal (Roitman 2004: 2I4). Often they become so intricately entangled with formal business that judicial systems cannot easily separate them (Nordstrom 2007: 89). Nor does it mean that we should think of the state as somehow 'failing'. What it does mean, however, as the editors argue in their introduction, is that such activities are systemic. They are fundamentally linked to state power rather than distinct from it, and may be just as likely to contribute to the making of the state as to breaking it.

Some commentators have argued that these illegal but licit practices do index the failure of governance and even the breakdown or demise of the state. Unregulated practices seem to be on the increase in many places, which for these commentators suggests a loss of state power. However, state power does not appear to be correspondingly diminished, despite the growth of such practices. Indeed, as the contributors show, these illegal acts are one way in which individuals can connect with the state. Bribes offered to state officials, for instance, draw those who offer them into a relationship with the state. They are an 'ambivalent secret' which, though 'surreptitious', have 'all the guarantee of the official' and in India should be regarded as 'the fundamental transaction of the ... state' rather than as a pathological symptom of its decline (Visvanathan \& Sethi 1998: 2-3, 6). Bribes and other illicit arrangements made with state officials might thus better be seen as 'ordinary spaces of negotiation' that reshape 'what citizenship means in practice' (Anjaria 20II: 58,59 ). A number of the chapters emphasise how bribes to state officials are a widespread and common form of interaction with the state in the areas they describe (Bakker \& Crain; Sur; Pattadath \& Moors). Nor are such interactions confined to local state officials but 
may extend to senior bureaucrats (Verkaaik, Khan \& Rehman) and to those in central government (Ford \& Lyons).

Many of the examples in the book thus testify to the fine line (or the absence of any such line) between the legal and the extra-legal, which runs right through the offices of the state and is sometimes just as difficult to discern by those who represent the state as by those who petition for the state's permission. Such examples raise complex questions about where the state 'begins' and 'ends' in a conceptual rather than territorial sense. When the state authorises acts that are ambiguously illegal - for instance, endorsing entry of undocumented labour at times of need but repatriating them during recession - the conceptual limits of the state become blurred. Yet this oscillation between importation and deportation may be central to state control of transnational labour migration - 'a necessary entailment of the state' that permeates it and allows it to function and thrive (Das \& Poole 2004: 4). In chapter one, Kalir tells us that to organise the flow of Chinese migrant labour to Israel, the two countries generally favour the dealings of private companies, including the informal and illegal ones. This leads to uncertainty about what is legal and what is not, a 'culturally infused confusion' that for the Chinese migrants is compounded by the range of actors and arrangements involved. Sometimes in China, where it is the efficiency of migration agencies rather than their legality that counts, 'legal agencies channel their clients illegally but undocumented brokers may channel their clients legally' (Li Minghuan). Certain legal orders may thus be selectively mobilised in one context but ignored or played down in another (Benda-Beckman et al. 2009: 5). Moreover, the benefits of legal status may be equivocal and expose an international migrant to the unwanted scrutiny of the state, as was the case for the huaqiao in early twentieth-century Japanese-administered Taiwan (Doux). Ignorance of illegality, lack of knowledge, dissimulation, pretence and contestation are therefore exacerbated by a hierarchy of gatekeepers that includes the recruitment companies and employers as well as the state itself, each with their own vested (and cultural) interpretations of what is legal. Legality is consequently a precarious condition, which may be granted by one of these but rescinded by another, with its boundary obscured as a result, as much for those who enforce the law as for those to whom the law is applied. This collection emphasises such conceptual boundaries - of the state and of the legal - and offers a privileged perspective on them. It opens up an opportunity to focus on the unreliability and unpredictability of the political meanings attached to ambiguously legal acts and the practical attempts to negotiate and 'fix' these meanings by the state and its citizens and non-citizens as well by those who seek to broker the relationships between them. 
In this approach, the state is no longer imagined as 'up there' operating at a level higher than the 'local' society it is said to regulate. Instead, the chapters repeatedly demonstrate the analytical advantages to be gained by questioning the analytical framework that Ferguson (2006) calls the 'vertical topography of power'. As Ferguson argues, rethinking the apparently self-evident 'verticality' of relations between state and society opens up new research possibilities by drawing attention to organisations and activities that do not straightforwardly fit the vertical analytic scheme in which power is seen as neatly nested. Both top and bottom now operate within an inescapably transnational context that exposes the artificiality of this spatial image of the state. As the contributors here show, many of the organisations and networks to which migrants belong and on which they depend for support and assistance when planning to migrate are simultaneously both local and global. They engage in activities which are impossible or misleading to categorise unequivocally as local, national or international since they show characteristics of each (much like Ferguson's NGOs). Rather than 'below' the state and subversive of it, they are better seen as existing alongside the state as 'horizontal contemporaries' that perform many different roles - 'sometimes rivals, sometimes servants, sometimes watchdogs, sometimes parasites, but in every case operating on the same level and in the same global space' (Ferguson 2006: I03).

However, the essays here argue not just that the state and the local are socially embedded in everyday life and must be seen as existing at the same 'level' rather than as hierarchically ranked. They also point to how the state and local are intimately enmeshed, not only because personnel from one are frequently implicated in the other, but also because they operate in complementary and mutually facilitative if sometimes contradictory and competing ways in an institutional division of labour situated within, although not always responsive to, the shifting requirements of transnational fields and the demands of those whose lives are lived across them. The cases analysed in this collection thus sharpen our focus on the transnational aspects of both state and local as players in the same field, a sporting metaphor that has in fact been used to describe the relationships in which they are involved (Li Minghuan).

Viewed from the perspective of the people whose transnational experiences and lives populate the pages of this book, the state can seem oddly mercurial, sometimes appearing as a strong central core with a radiating penumbra of actors with ambivalent and shifting claims to authority and at other times as an amorphous, murky organisation encompassing people whom it is impossible to distinguish in terms of their status as state or non-state agents. For these transnationals, authority tends to reside in people rather than structures, and migrant livelihoods and well-being come to depend on picking a 
pathway through this field of competing and overlapping authorities as many of the chapters here so sensitively show. It is a world of negotiated order where, as the editors stress, mutually acceptable practice must be established to generate a sense of local stability. But for life merely to proceed, of course, mutually acceptable practice need not necessarily be established. As we read in these pages, many migrant lives are lived out in a shadowy world of official non-existence characterised by the social and political invisibility necessitated by the lack of bureaucratic documentation. At the same time, it is a world chronically threatened by heightened visibility brought about by the ever-present possibility of official detection and exposure and the penalties that so often follow, such as deportation. This dance of the undocumented plays out as far as possible beyond the spotlights of the state but always to a script whose terms and roles are loaded and usually state-centric, such as 'undocumented' and 'illegal'.

In anthropology, the paradigmatic approach to the study of undocumented and illegal migrant labour derives largely from studies of the Mexico-US border. Much of this research has focused on the experience of 'illegality' and the daily challenges, uncertainties and vulnerabilities of undocumented life. For example, as Leo Chavez (I992: iı6) has shown, undocumented Mexican migrants in California are ascribed a set of negative identities as 'illegal residents, transients, homeless, poor, unemployed or temporarily unemployed, criminals or potential criminals'. Such layered exclusions ensure that they remain liminal outsiders isolated from the rest of society, however much they might imagine themselves to be part of the larger community. So too work that has reconceptualised the key terms of the debate about undocumented migration has also taken the American case and Mexico-US border as its starting points. Thus De Genova (2002), for instance, uses Mexican migration to the US to argue that while it is clearly important to understand the consequences and subjectivities of migrant 'illegality', we must also account for the historically situated socio-political processes that produce 'illegality' in the first place.

One of the great achievements of this book is thus to move the focus beyond the US by bringing together studies of parts of the world where undocumented migration has too often been ignored by anglophone scholarship. Case studies from the Middle East, India, Bangladesh, Indonesia and China add a critical comparative perspective to the field, documenting the enormous scale of illegal migration from some of these countries as well as the range of destinations to which these migrants move. Moreover, the historical and sociopolitical processes through which illegality is produced within these settings varies widely and results in an 'ecology of licitness' that differs in its socio-cultural topography and expression from one place to the next. Inclusion or 
exclusion from state categories of belonging may manifest itself in different ways in different places, and be tempered by different, non-state 'moral geographies' rooted in alternative international religious and legal codes (as Wong and Suan show for the Rohingyas). Only a comparative perspective sensitive to historical and cross-cultural variation such as that adopted throughout this volume is able to draw this out. In order to grasp what brings about the local moral and cultural acceptability of a particular illegal act, therefore, we must add to an understanding of the processes that produce illegality a complementary understanding of the socio-cultural processes, economic contexts and regulatory regimes through which some practices come to be considered as licit within specific permissive polities. This book outlines how this might look by insisting that we examine the conditions that produce illegal migration and the moral context in which it occurs.

In this view, illegality is 'a preeminently political identity'; it is not outside the state but entails a relationship to it (De Genova 2002: 422). But it is a relationship that is simultaneously stripped of the 'political' by a denial or refusal of rights. Undocumented migrants find that even their most mundane activities can be transformed into illegal acts by the routine regulation of working, driving and travelling, when they may be stopped and asked to show their licence. In other words, as De Genova (2002: 429) has argued, rendering them 'illegal' is as much about including them in society under conditions of vulnerability as it is about excluding them altogether. This involves a process of 'irregularization', a term that Squire (20II) prefers to 'illegality', since it foregrounds the agency of the migrant and avoids the imputation of criminality associated with 'illegal'. Rather than being a fixed property or condition of a person, irregularity only becomes such when the movement of people becomes a target of control, so that it should be understood and approached analytically as something that people may move in and out of (Squire 20II: 7). Viewed in this way, through irregularity as the analytic frame, the politics of mobility is no longer automatically associated with a particular agent or subject position. Although it is usually migrants who act out a politics of mobility and the state and international organisations that perform a politics of control, the interrelations and struggles between these are more complex than this bold dichotomy allows. According to Squire (20II: I3), we should therefore not assume that the basis of such struggles lies in a 'juridical or scalar logic' but examine instead the "multiplicity of struggles through which irregularity is constituted as an ambivalent and contested socio-political condition'.

Such an approach clearly resonates with many of the examples in this collection, where migrants move through a political field in which their circumstances and efforts to engage them are rarely determined in any 
simple way by the sovereign boundaries they have crossed or the shifting efforts to regulate their movement. Kalir, for example, exposes the shortcomings of objectivist approaches to migration that deny the role of international and transnational agencies in producing irregularity and illegality and attribute these to the criminal or illegal intent of migrants themselves. His account of how migrant agencies in China charge for Israeli work permits and of the subsequent experience of Chinese labour in Israel reaffirms the need to analyse illegality as the result of more than just legal codes and the strictures of the state. In the case of Chinese migrant labour in Israel, it is the actions of a range of people beyond state bureaucracies that are responsible for constituting the status of individuals as either 'citizens' or 'illegals' (cf. Coutin I993).

I alluded earlier to the notion of moral disjunctions, and it is worth returning to this briefly to consider how illegality can be differently constituted as licit across a range of contexts and individuals. Like 'illegality', moral acceptability or licitness is not a self-evident characteristic or property of particular activities or forms of mobility. As already noted, it too is obviously the outcome of sociopolitical processes that may or may not define it as such. Nor, of course, need there be consensus over the acceptability of a specific action and, as many of the examples in this collection illustrate, the licitness of 'illegal' mobilities may be contested by more than just the legal arm of the state. This again is why the notion of 'ecology' is important, as it draws attention to the relationships between licitness and its wider sociocultural environment, relationships which may be diverse, flexible and capricious.

The chapters in this book thus stimulate us to ask about the processes and conditions under which particular activities come to be considered as licit. The chapter by Ford and Lyons, for example, explores the rules and conditions under which certain forms of cross-border smuggling come to be regarded as acceptable in the IndonesiaSingapore borderlands and how this permissiveness is shaped by wider political issues and developments that through time variously classify the activity as 'smuggling' or 'trade' and the merchandise transported as 'legal goods' or 'contraband'. Profit is only one factor promoting involvement in this trade, and quality of goods, convenience and speed of delivery have all contributed to smuggling being considered normal. At the same time, Ford and Lyons point out, licitness has its moral boundaries, whereby smuggling of everyday necessities is more acceptable than smuggling goods for profit. Such 'ecologies of licitness' are echoed elsewhere. To understand why neither the Spanish nor Moroccans condemn as illegal or immoral the smuggling to and from the Spanish enclave of Melilla in North Africa, for instance, we need to know about the cultural context and how it is underwritten by notions 
of manliness, cunning and a value on autonomy, independence and success. To take risks is part of the ethos of masculinity in Melilla. The perceived corruption of the state further encourages people to see small-scale, periodic, 'subsistence' smuggling as a culturally acceptable way of surviving where economic opportunities are limited. At the same time, however, this moral neutrality is not extended to the large-scale, highly organised professional smuggling of luxury goods and hashish (Driessen I999: I24-5). Similarly, amidst high security at the IndiaBangladesh border, small-scale smuggling may pass freely as long as it is conducted by women, and perishables are sharply distinguished from drugs and precious metals by being widely accepted as a licit commodity for cross-border trade while the latter are shunned (Sur, this volume). Clearly, gender and operational scale and scope shape local moral evaluations of certain kinds of mobility, even when these are in the same general domain of smuggling, as in this case. So too competing interests and different interpretations of what is in the common good may obscure the boundaries of acceptability (see Ferme 2004: 83). Thus many ordinary Rifians in Melilla reject attempts by the drug barons to purify the proceeds of their smuggling by building mosques for the wider use of local communities. To understand what is licit here, we must grasp such conflicting or overlapping interests and the intersubjectivity of the production of permissiveness.

These disjunctive moralities - in which right and wrong are not neatly aligned with what is legal and illegal - generate a mismatch that is scrutinised by the chapters here. However, they do not only generate a mismatch. They also often overlap and coincide. But as the chapters here show, these overlapping correspondences should not be taken for granted as the naturally occurring default position of what is legal with what is right. Such conjunctions are historically contingent and must be problematised and explored. The collection encourages us to think about the moral hierarchies that result and the processes and criteria that underlie them and to come to see how these too are socially and spatially dispersed, a perspective that again challenges the idea that the state functions at a 'higher level' than the local by virtue of its claims to superior moral purpose (Ferguson 2006: 92).

Above all, this book reminds us that anthropology is good at exploring intersections and interconnections, working within and across the gaps created by the broader analytical dichotomies that have shaped so much social research on the state and human mobility. It pursues the consequences of a central irony: that while borders are a material representation of the state and its laws, their mere presence generates lawbreaking by those who seek to transfer or transform value by crossing from one side to the other. Crossings contest state efforts to manage flow. As the contributors so compellingly demonstrate, this results in 
the inter-legalities and cross-cutting moralities through which, and despite which, so many people must now work out their lives as they navigate the uncertainties of different norms and rules and the ambivalent moral landscape where diverse interpretations of appropriateness and legality meet, merge and collide. The conjunction of illegality and the licit that this volume takes as its theme is clearly good to think with, and the authors not only open up the broader theoretical and conceptual questions that their substantive focus on human mobility raises but also suggest productive ways in which these might be engaged and addressed. 



\section{About the Editors and Contributors}

\section{The Editors}

Barak Kalir is assistant professor in the Department of Anthropology and Sociology, University of Amsterdam. He is the director of the Contemporary Asian Studies Master programme at the Graduate School of Social Sciences (GSSS), and the co-director of the Institute for Migration and Ethnic Studies (IMES). His ethnographic work on migrants from Latin America and China has been published in leading journals including International Migration, Social Anthropology, and Sociology of Religion. His recent book Latino Migrants in the Jewish State: Undocumented Lives in Israel (Indiana University Press) has been nominated by the Society for Economic Anthropology for the best book published over the last three years in economic anthropology.

Malini Sur is pursuing a PhD at the Amsterdam Institute for Social Science Research, University of Amsterdam. Her research interests include the anthropology of borders and violence. Her dissertation on the India-Bangladesh border exposes the ambivalence of this region as one composed of lethal locations, and as interconnected sites that sustain quotidian forms of movement and exchange (scheduled to be completed by mid 20I2). She has lectured at the University of Amsterdam and participated in debates on labour migration policies in Europe. Prior to her appointment at the Amsterdam Institute, she worked for five years with the South Asia Program of the Social Science Research Council (New York). Photographs from her fieldwork have been exhibited in Kathmandu, Chiang Mai, Amsterdam, Göttingen, Berlin and Bonn.

\section{The Contributors}

Laurens Bakker is lecturer and researcher at the Institute of Cultural Anthropology and Development Studies (CAOS) and at the Institute of Sociology of Law at the Radboud University Nijmegen, the Netherlands. His research interests include land conflict and natural resource 
management, discourses of rights and the dynamics of law and normativity as guiding principles for social and economic communities. He has worked on these issues in Southeast Asia, notably Indonesia, and the Netherlands.

Jay Bouton Crain is Professor Emeritus, Anthropology and Asian Studies, at CSU Sacramento. His Ph.D. in social anthropology is from Cornell University. He was an Assistant Clinical Professor of Psychiatry at UC Davis and co-founder of the Graduate Group in Clinical Psychology. At CSU Sacramento he founded the Asian Studies Program. He has conducted extended research in Borneo and the Republic of Singapore and shorter periods of fieldwork in the Trobriand Islands and East Java. He has authored and co-authored articles, chapters and a dictionary of Lundayeh. His research interests are in ideology, social practice and religious experience.

Hastings Donnan is Professor of Social Anthropology at Queen's University Belfast and Co-Director of the Centre for International Borders Research. He has carried out fieldwork in Pakistan and Ireland and has published over twenty books, including The Anthropology of Sex (2010), Borderlands: Ethnographic Approaches to Security, Power and Identity (2010), The Anthropology of Ireland (2006), Culture and Power at the Edges of the State (2005), Interpreting Islam (2002), and Borders: Frontiers of Identity, Nation and State (200I). He is a Member of the Royal Irish Academy and a Founding Academician of the UK's Academy of Social Sciences.

Leo Douw is a lecturer in Modern Chinese society and history at the University of Amsterdam and at the VU University of Amsterdam. His main fields of interest are Chinese intellectual history, the history of Chinese overseas communities and business, and migration studies. At present he is working mainly at the histories of Chinese migrants in Taiwan and Taiwanese migrants in South China during the Japanese period (I895-I945).

Michele Ford is Associate Professor in the Department of Indonesian Studies at the University of Sydney. Her research interests focus on social activism in Southeast Asia and the Indonesia-Singapore borderlands. Michele is the author of Workers and Intellectuals: NGOs, Unions and the Indonesian Labour Movement (NUS/Hawaii/KITLV 2009) and co-editor of Women and Work in Indonesia (Routledge 2008, with Lyn Parker) and Women and Labour Organizing In Asia: Diversity, Autonomy and Activism (Routledge 2008, with Kaye Broadbent). 
Sarfraz Khan is currently Director, Area Study Centre (Central Asia), University of Peshawar, Peshawar, Pakistan. He is author of Muslim Reformist Political Thought: Revivalists, Modernists and Free Will (2003), and numerous other publications. His research interests include Central Asia, Afghanistan, Ethnicity, Islam, Reform, Federally Administered Tribal Areas (FATA), among other areas. Dr. Khan held a post fellowship under the "Licit but Illegal" Research Programme at Amsterdam School of Social Sciences Research (ASSR), Netherlands in 2006 investigating the borderlands of Pakistan and Afghanistan.

Praveena Kodoth is an Associate Professor at the Centre for Development Studies, Trivandrum (India). Her research interests lie in the use of gender to interpret institutions and socio-economic processes. She has published papers on the transformation of property relations among matrilineal 'Hindus' and patrilineal Christians in Travancore, a gender critique of social development in Kerala and the institutionalization of dowry in contemporary Kerala. She teaches a course on gender and development with specific reference to the Indian Economy.

Lenore Lyons is Honorary Professor in Southeast Asian Studies at the University of Sydney. Her publications include A State of Ambivalence: The Feminist Movement in Singapore (Brill Academic Publishers, Leiden, 2004), Men and Masculinities in Southeast Asia (Routledge, London, 2OII, co-edited with Michele Ford), and Labour Migration and Human Trafficking: Critical Perspectives from Southeast Asia (Routledge, London, in press, co-edited with Michele Ford and Willem van Schendel).

Li Minghuan is a professor in Xiamen University, PRC and holds a doctorate in sociology from University of Amsterdam, the Netherlands. Her research interests include Chinese transnational migration and sending community culture. She has published widely in Chinese and English, in China and abroad.

Annelies Moors is an anthropologist and directs a programme on Muslim Cultural Politics at the University of Amsterdam. She has published widely in such fields as Muslim marriages and family law, wearing gold, the visual media (postcards of Palestine), migrant domestic labour, and fashionable and not so fashionable styles of Islamic dress (see http://sites. google.com/site/anneliesmoors).

Bindhulakshmi Pattadath is an Assistant professor at the Centre for Women's Studies in Tata Institute of Social Sciences, Mumbai where she teaches Women and Work, History of transformation and Women 
and History and Social change. Her research interests are Gender and Labour Migration, Mental health, and Ethnography. She obtained a PhD in Sociology from Indian Institute of Technology, Bombay and was a post-doctoral fellow at Amsterdam Institute of School for Social Science Research, University of Amsterdam. She conducted her fieldwork in Kerala and Dubai among Malayalee Migrant Women domestic workers.

Samina Rehman is a Lecturer at the Department of Philosophy, University of Peshawar, Pakistan. She has been teaching Ethics, Muslim Philosophy and Philosophy of Science. She is currently engaged in writing her doctoral dissertation Gender Consciousness amongst Pukhtun in Afghanistan and Pakistan at Area Study Centre (Central Asia), University of Peshawar. Her research interests include Gender and Socio-political Reforms in Pukhtun Society especially in Federally Administered Tribal Areas, FATA, also Gender and Peace in Afghanistan and Pakistan.

Willem van Schendel is Professor of Modern Asian History at the University of Amsterdam and heads the South Asia Department of the International Institute of Social History. Recent books include The Bengal Borderland: Beyond State and Nation in South Asia (2005), Illicit Flows and Criminal Things: States, Borders and the Other Side of Globalization (2005, co-edited with Itty Abraham) and A History of Bangladesh (2009).

Tan Pok Suan earned her M.A. at Universiti Kebangsaan Malaysia with a study on Rohingya migrants in Malaysia. She is currently helping to edit a memoir written by a Rohingya migrant from Saudi Arabia.

V.J. Varghese is Assistant Professor at the Centre for Development Studies, Thiruvananthapuram, India. His research interests include migration and the production of transnational spaces, history of Developmentalism, Economic modernities of South Asia and making of modern Malayalee self. He has recently co-authored the book Dreaming Mobility and Buying Vulnerability: Overseas Recruitment Practices and its Discontents in India (forthcoming Routledge India).

Oskar Verkaaik is associate professor affiliated with the Department of Anthropology of the University of Amsterdam. He has worked on nationalism, ethnicity and Islam in Pakistan, particularly urban Sindh. More recently he is working on nationalism, secularism and Islam in Europe and South Asia. His publications include Migrants and Militants: Fun and Urban Violence in Pakistan (Princeton University Press). He has published in, among others, Social Anthropology, Critique of Anthropology, and American Ethnologist. 
Diana Wong is Visiting Professor at Kanita (Women's Development Research Centre), Universiti Sains Malaysia, Penang. Her recent work has been in the area of migration studies, with a special interest in the nexus between migration and religion. She is currently working on the new Chinese migration to Southeast Asia. 



\section{Bibliography}

Abbas, H. (2008), 'A profile of Tehrik-i-Taliban Pakistan', CTC Sentinel I (2): I-4.

Abraham, I. \& W. van Schendel (2005), 'Introduction: the making of illicitness', in W. van Schendel \& I. Abraham (eds.), Illicit flows and criminal things: states, borders, and the other side of globalization, I-37. Bloomington: Indiana University Press.

Abrams, P. (1988), 'Notes on the difficulty of studying the state', in Journal of Historical Sociology I/I: 58-89.

Abu-Lughod, L. (1986), Veiled sentiments: honor and poetry in a Bedouin society. Berkeley. University of California Press.

Adams, K. \& S. Dickey (eds.) (2000), Home and hegemony: domestic service and identity politics in South and Southeast Asia. Ann Arbor: University of Michigan Press.

Agamben, G. (I995), 'We refugees', in Symposium vol 49 (2) Summer: II4-II9, [translated by Michael Rocke] http://www.egs.edu/faculty/giorgio-agamben/articles/we-refugees

- (1998), Homo sacer: sovereign power and bare life. Stanford: Stanford University Press.

- (2005), State of exception. (translated by K. Atell) Chicago: University of Chicago Press.

al-Najjar, S. (2004), 'Women migrant domestic workers in Bahrain', in S. Esim \& M. Smith (eds.), Gender and migration in the Arab states: the case of domestic workers, Beirut: Regional International Labour Organisation, Regional Office of the Arab States.

Amster, M. (2005), 'The rhetoric of the state: dependency and control in a MalaysianIndonesian borderland', in Identities: Global Studies in Culture and Power I2 (I): 23-43.

- (2006), 'Narrating the border. Perspectives from the Kelabit Highands of Borneo', in A. Horstmann \& R. Wadley (eds.), Centering the margin: agency and narrative in Southeast Asian borderlands, 207-228. Oxford/New York: Berghahn Books.

Anders, G. \& M. Nuijten (2007), 'Corruption and the secret of law: an introduction', in M. Nuijten \& G. Anders (eds.), Corruption and the secret of law. A legal anthropologist perspective, I-26. Aldershot/Burlington: Ashgate Publishing Limited.

Andreas, P. (2000), Border Games: Policing the U.S.-Mexico Divide. Ithaca: Cornell University Press.

Anjaria, J.S. (20II), 'Ordinary States: Everyday Corruption and the Politics of Space in Mumbai', in American Ethnologist 38 (I): 58-72.

Antonopoulos, G. (2008), 'The Greek connection(s): the social organization of the cigarettesmuggling business in Greece', in European Journal of Criminology 5 (3): 263-288.

Appadurai, A. (1990), 'Disjuncture and difference in the global cultural economy', in Public Culture 2 (2): I-23.

- (I997), 'Sovereignty without territoriality. notes for a postnational geography', in P. Yeager (ed.), The Geography of Identity. Ann Arbor: University of Michigan Press.

Ardhana, I., J. Langub \& D. Chew (2004), 'Borders of kinship and ethnicity. cross-border relations between the Kelalan Valley, Sarawak and the Bawan Valley, East Kalimantan', in Borneo Research Bulletin 35: I44-I79.

Asad, T. (I972), 'Market model, class structure and consent: a reconsideration of Swat political organisation', in Man 7/I: 74-94.

— (2007), On suicide bombing. New York: Columbia University Press. 
Bade, K. (2000), Europa in Bewegung. Migration vom späten 18. Jahrhundert bis zur Gegenwart [Europe in motion. Migration from the late $18^{\text {th }}$ century until the present]. München: C.H. Beck Verlag.

Bagchi, J. \& S. Dasgupta (2003), The trauma and the triumph: gender and partition in eastern India. Kolkata: Stree.

Bakker, L. (2008), “'Can we get hak ulayat?” Land and community in Pasir and Nunukan', paper presented at UC Berkeley \& UCLA joint conference 'Ten Years After: Reformasi and New Social Movements in Indonesia, I998-2008', University of California, Berkeley, 25-26 April. http://repositories.cdlib.org/cseas/CSEASWP2-o8/

Bal, E. (2007), They ask if we eat frogs: Garo ethnicity in Bangladesh. Singapore: ISEAS.

Bal, E. \& T. Claquin (20IO), '(Re) interpreting the indigenous peoples' discourse in different spaces: a case study of the Garos of India and Bangladesh', paper presented at conference in Chiang Mai, Thailand on Asian Borderlands: Enclosure, Interaction and Transformation, 5-7 November 2010.

Bala, P. (2002a), Changing borders and identities in the Kelabit Highlands. Kuching: Lee Ming Press Company.

- (2002b), 'Interethnic ties along the Kalimantan-Sarawak border: The Kelabit and Lun Berian in the Kelabit-Kerayan highlands', in Borneo Research Bulletin 32: I03-III.

Balibar, E. (2003), We, the people of Europe? Princeton: Princeton University Press.

Banerjee, P. (2010), Borders, histories and existences: gender and beyond. New Delhi: Sage.

Banerjee, P., S. Hazarika, M. Hussain \& R. Samaddar (I999), 'Indo-Bangladesh cross-border migration and trade', in Economic and Political Weekly 34 (36): 2549-255I.

Bangash, A. (I996), 'Political and administrative development of tribal areas: a focus on Khyber and Kurram'. Unpublished dissertation, University of Peshawar.

Bank of Israel. (2000), Press release, December (Hebrew).

Barker, J. (200I), 'State of fear: controlling the criminal contagion in Suharto's New Order', in B. Anderson (ed.), Violence and the state in Suharto's Indonesia, 20-53. Ithaca: Cornell University \& Southeast Asia Program Publications.

Barr, C., E. Wollenberg, G. Limberg, N. Anau, R. Iwan, I. M. Sudana, M. Moeliono \& T. Djoga (200I), The impacts of decentralization on forests and forest-dependent communities in Kabupaten Malinau, East Kalimantan. Bogor: Center for Social Forestry Research.

Barth, F. (I959), Political leadership among Swat Pathans. London: Athlone Press.

Barth, G. (I964), Bitter strength: A history of the Chinese in the United States, 1850-1870. Cambridge: Harvard University Press.

Bartram, D. (I998), 'Foreign workers in Israel: history and theory', in International Migration Review 32 (2): 303-325.

Bar-Tzuri, R. (I996), 'Foreign workers in Israel: conditions, attitudes and policy implications', in R. Nathanson (ed.), The new world of work in an era of economic change, 3I-64. Tel-Aviv: Friedrich Ebert Foundation (Hebrew).

Baruah, S. (I999), India against itself: Assam and the politics of nationality. Philadelphia: University of Pennsylvania Press.

Baud, M. \& W. van Schendel (I997), 'Toward a comparative history of borderlands', in Journal of World History 8 (2): 2II-242.

Baumann, G. (I996), Contesting culture: discourses of identity in multi-ethnic London. Cambridge: Cambridge University Press.

Benhabib, S. (2004), The rights of others: aliens, residents and citizens. Cambridge: Cambridge University Press.

Bhagwati, J. (2003), 'Borders beyond control', in Foreign Affairs 82 (I): 98-I04.

Bourdieu, P. (I996), The state nobility: elite schools in the field of power. Cambridge: Polity.

Bowen, J. (2004), 'Beyond migration: Islam as a transnational public space', in Journal of Ethnic and Migration Studies 30 (5): 879-894(I6).

Breman, J. (I989), Taming the coolie beast. Calcutta: Oxford University Press. 
Business Standard (2009), 'Meghalaya likely to be first NE state to get UIN', August 27.

Butalia, U. (2000), The other side of silence: voices from the partition of India. New Delhi: Penguin India.

Carter, M. (I995), Servants, sirdars, and settlers: Indians in Mauritius, I834-1874. Delhi/New York: Oxford University Press.

- (I996), Voices from indenture: experiences of Indian migrants in the British Empire. London/ New York: Leicester University Press.

Castles, S. (2004), 'The factors that make and unmake migration policies', in International Migration Review 38 (3): 852-884.

Center for Development Studies, India (2009), Background Report for National Policy on International Migration, unpublished report (www.cds.edu).

Central Bureau of Statistics (2000), Statistical Abstract of Israel, Jerusalem: CBS.

Central Bureau of Statistics (2002), Statistical Abstract of Israel, Jerusalem: CBS.

Central Bureau of Statistics (2007), Press release, 30 July 2007.

Chammartin, G. (2004), “Women migrant workers” protection in the Arab League states', in S. Esim \& M. Smith (eds.) Gender and migration in the Arab States: the case of domestic workers, 7-23. Beirut: International Labour Organisation, Regional Office of the Arab States.

Chan, A. (2005), 'The development of a Muslim enclave in Arakan (Rakhine) State of Burma (Myanmar)', in SOAS Bulletin of Burma Research 3 (2): 396-420.

Chang, W. (2004), 'Guanxi and Regulation in Networks: The Yunnanese Jade Trade between Burma and Thailand, I962-88', in Journal of Southeast Asian Studies 35 (3): 479-50I.

Chatterjee, N. (I992), 'Midnights unwanted children: East Bengali refugees and the politics of rehabilitation'. Masters' thesis, Brown University.

Chatterji, J. (I999), 'The fashioning of a frontier: the Radcliffe line and Bengal's border landscape, I947-52', in Modern Asian Studies 33: 185-242.

Chavez, L.R. (1992), Shadowed Lives: Undocumented Immigrants in American Society. Orlando: Harcourt Brace Jovanovich College Publishers.

Chen, H. (ed.) (I984), Huagong chuguo shiliao huibian [Documents collection on Chinese coolies abroad]. Beijing: Zhonghua shuju.

Chen, K. (I999), Xiamen shihua [A history of Xiamen]. Xiamen: Lujiang chubanshe.

Chin, K. (I999), Smuggled Chinese: clandestine immigration to the United States. Philadelphia: Temple University Press.

Cohn, B. (1996), Colonialism and its forms of knowledge: the British in India. Princeton: Princeton University Press.

Cohen, E. (I995), 'Israel as a post-Zionist society', in R. Wistrich \& D. Ohana (eds.), The shaping of Israeli identity, 203-2I4. London: Frank Cass.

Conboy, K. (2003), Kopassus. Inside Indonesia's special forces. Jakarta/Singapore: Equinox Publishing.

Cornelius, W., P. Martin \& J. Hollifield (I994), Controlling immigration: a global perspective. Stanford: Stanford University Press.

Coutin, S.B. (I993), The Culture of Protest: Religious Activism and the US Sanctuary Movement. Boulder: Westview Press.

Crain, J. \& V. Pearson-Rounds (I999a), 'Autochthony and authenticity: migration and mission as themes in recent Lundayeh-Lun Bawang history', paper presented at the Annual Meeting of the American Anthropological Association, Philadelphia, 2-6 December.

Crain, J. \& V. Pearson-Rounds (I999b), 'Wet rice in inner Borneo. The social and physical ecology of the Lundayeh/Lun Bawang Lati' Ba' system', in V. King (ed.), Rural development and social science research: cases studies from Borneo, 32I-336. Phillips: The Borneo Research Council.

Crain, J. \& V. Pearson-Rounds (I999C), A provisional bibliographic list of published materials and manuscripts relating to the Lundayeh-Lun Bawang-Kelabit and related groups of Sabah, 
Sarawak, Brunei and East Kalimantan. Kuching: Occasional Paper No. I, Institute for East Asian Studies, Universiti Malaysia Sarawak.

Crain, J. \& V. Pearson-Rounds (2005), 'A fallen bat, a rainbow, and the missing head: media and marginalization in upland Borneo', in Indonesia 79: 56-68.

Dahan, Y. \& A. Gill (2006), 'Between neo-liberalism and ethno-nationalism: the policy and law of deporting migrant workers' (Hebrew), in Mishpat u'Mimshal Io(I): 347-385.

Das, V. \& D. Poole (2004), Anthropology at the margins of the state. New Delhi: Oxford University Press.

De Genova, N. (2002), 'Migrant “Illegality” and Deportability in Everyday Life', in Annual Review of Anthropology 31: 4I9-47.

Derrida, J. (2000), Of hospitality. Stanford: Stanford University Press.

Direktorat Kewilayahan II Deputi Bidang Pengembangan Regional dan Otonomi Daerah [Directorate Region II Deputy Sectors Regional Development and Regional Autonomy BAPPENAS] (2006) Rencana Induk Pengelolaan Perbatasan Negara Buku Rinci di Provinsi Kalimantan Timur [Master plan for the management of the state border book of details for the Province of East Kalimantan]. http://kawasan.bappenas.go.id/k_perbatasan/data_batas/ bukurinci_ kaltim.pdf

Donnan, H. \& T. Wilson (I999), Borders: frontiers of identity, nation and state. Oxford: Berg.

Douw, L. (I999), 'The Chinese sojourner discourse', in L. Douw, C. Huang \& M. Godley (eds.), Qiaoxiang Ties: Interdisciplinary Approaches to 'Cultural Capitalism' in South China, 22-45. London: Kegan Paul International.

Driessen, H. (I999), 'Smuggling as a Border Way of Life: A Mediterranean Case', in M. Rösler \& T. Wendl (eds.), Frontiers and Borderlands: Anthropological Perspectives. Frankfurt am Main: Peter Lang.

Drori, I., \& G. Kunda (I999), The work experience of foreign workers in Israel: the case of Filipino caregivers, Thais in agriculture and Rumanians in construction. Discussion Paper No. Ioo, Golda Meir Institute.

Duara, P. (1997), 'Nationalists among transnationals: overseas Chinese and the idea of China, I900-I9II', in A. Ong, \& D. Nonini (eds.), Ungrounded empires, the cultural politics of modern Chinese transnationalism, 39-61. New York/London: Routledge.

Erickson, Edgar L. (I934), 'The introduction of East Indian Coolies into the British West Indies', in The Journal of Modern History, VI (2), I27-I46.

Esim, S. \& M. Smith (eds.) (2004), Gender and migration in the Arab States: the case of domestic workers. Beirut: International Labour Organisation, Regional Office of the Arab States.

Euben, R. (I999), Enemy in the mirror: Islamic fundamentalism and the limits of modern rationalism. Princeton: Princeton University Press.

Evans-Pritchard, E. (1940), The Nuer: a description of the modes of livelihood and political institutions of a Nilotic People. Oxford: Oxford University Press.

Ferguson, J. (2006), Global Shadows: Africa in the Neoliberal World Order. Durham: Duke University Press.

Ferme, M.C. (2004), 'Deterritorialized Citizenship and the Resonances of the Sierra Leonean State', in V. Das \& D. Poole (eds.), Anthropology in the Margins of the State. Oxford: James Currey Ltd.

Fernandes, W. (2005), 'IMDT Act and Immigration in North-Eastern India'. Economic and Political Weekly 40, no. 30: 3237-40.

Flynn, D. (I997), “We are the border”: identity, exchange, and the state along the BéninNigeria border', in American Ethnologist 24 (2): 3II-30.

Ford, M. \& L. Lyons (2006), 'The borders within: mobility and enclosure in the Riau Islands', in Asia Pacific Viewpoint 47 (2): 257-7I. 
Ford, M. \& L. Lyons (2008), 'Making the best of what you've got: sex work and class mobility in the Riau Islands', in M. Ford \& L. Parker (eds.), Women and Work in Indonesia, I73-94. London: Routledge.

Ford, M. \& S. Tjandra (2007), The local politics of industrial relations: Surabaya and Batam Compared, paper presented at the Indonesia Council Open Conference, Monash University, 24-25 September.

Foucault, M. (I979), 'On governmentality', in Ideology \& Consciousness 6: 5-2I.

Gallo, E. (2005), 'Unorthodox sisters: gender relations and generational change among Malayali migrants in Italy', in Indian Journal of Gender Studies I2 (2\&3): 2I7-25I.

Gamburd, M. (2000), The kitchen spoon's handle: transnationalism and Sri Lanka's migrant housemaids. Ithaca: Cornell University Press.

George, S. (2005), When women come first: gender and class in transnational migration. Berkeley: University of California Press.

Gardner, A. (2010), 'Engulfed: Indian Guest Workers, Bahraini Citizens and the Structural Violence of the Kafala System', in Nicholas De Genova \& Nathalie Peutz (eds.), The Deportation Regime: Sovereignty, Space, and Freedom of Movement, I96-223. Durham: Duke University Press.

Ghanem, A. (I998), 'State and minority in Israel: the case of ethnic state and the predicament of its minority', in Ethnic and Racial Studies, 2I (3): 428-447.

Ghosh, K. (2006), 'Between global flows and local dams: indigenousness, locality, and the transnational sphere in Jharkhand, India', in Cultural Anthropology 2I (4): 50I-534.

Gilsenan, M. (1996), Lords of the Lebanese marches: violence and narrative in an Arab Society. London: I.B. Tauris.

Golub, S. \& A. Mbaye (2009), 'National trade policies and smuggling in Africa: the case of the Gambia and Senegal', in World Development 37 (3): 595-606.

Gotō, K. (2004), 'Japan's southward advance and colonial Taiwan', in European Journal of East Asian Studies 3(I): I5-44.

Government of India, Press Information Bureau (200I), 'India-Bangladesh sign MOU for establishing border Haats, Ministry of Commerce and Industry', Meghalaya Legislative Assembly, I6 March 200I, Address by M. M. Jacob, Governor of Meghalaya. http://pib.nic. in $/$ release/release.asp?relid $=66525$, accessed on 5 January 201 I.

Grima, B. (2005), The performance of emotion among Paxtun women: the misfortune which have befallen me. Oxford: Oxford University Press.

Grundy-Warr, C. \& E. Wong (I997), 'Sanctuary under a plastic sheet: the unresolved problem of Rohingya refugees', in International Boundaries Research Unit, http://www.dur.ac.uk/ ibru/publications/view/?id=II6, accessed i9 April 2009.

Gulati, L. (I993), In the absence of their men: the impact of male migration on women. New Delhi: Sage.

Guhathakurta, M. (2004), 'Women Negotiating Change: The Structure and Transformation of Gendered Violence in Bangladesh', in Cultural Dynamics I6: I93-2II.

Gupta, A. (I995), 'Blurred Boundaries: The Discourse of Corruption, the Culture of Politics, and the Imagined State', in American Ethnologist 22 (2): 375-402.

Handique, M. (2006), 'Bangla fencing put on hold as farmers protest', in The Indian Express, November I4.

Hansen, K. (I99I), 'Domestic service. What's in it for anthropology?', in Reviews in Anthropology I6 (I): 47-62.

Hansen, T. \& F. Stepputat (200I), States of imagination: ethnographic explorations of the postcolonial state. Durham: Duke University Press.

Hansen, T. \& F. Stepputat (2005), Sovereign bodies: citizens, migrants, and states in the postcolonial world. Princeton: Princeton University Press. 
Harris, N. (1996), The new untouchables: immigration and the new world worker. London: Penguin Books.

Hazarika, S. (2000), Rites of Passage: border crossings, imagined homeland, India's east and Bangladesh. New Delhi: Penguin.

Heyman, J. \& A. Smart (I999), 'States and illegal practices: an overview', in J. Heyman \& A. Smart (eds.), States and illegal practices, I-24. Oxford and New York: Berg Publishers.

Hidayat, H. (2005), 'Kehutanan dan Perdagangan Kayu Illegal di Nunukan' [Forestry and the illegal log trade in Nunukan], in R. Tirtosudarmo \& J. Haba (eds.), Dari Entikong sampai Nunukan. Dinamika daerah perbatasan Kalimantan Malaysia Timur (Serawak-Sabah) [From Entikong to Nunukan. dynamics of the Kalimantan East Malaysia (Serawak Sabah) border areas], 245-276. Jakarta: Pustaka Sinar Harapan.

Hindley, D. (I964), 'Indonesia's confrontation with Malaysia: a search for motives', in Asian Survey 4 (6): 904-I3.

Hollifield, J. (2005), 'The emerging migration state', in I. Toshio \& I. Masako (eds.) Motion in Place/Place in Motion, $21^{\text {st }}$ Century Migration, 19-44. Osaka: Japan Center for Area Studies.

Hotline for Migrant Workers (2003), For you were strangers: modern slavery and trafficking in human beings in Israel. www.hotline.org.il/english/pdf/For_you_were_strangers_2nd_edition_ Eng.pdf

Hotline for Migrant Workers and Kav La'oved (2003), Immigration administration or expulsion unit? www.hotline.org.il/english/pdf/Hotline_and_Kav_Laoved_paper_on_Immigration_ Police_May_2003_Eng.pdf.

Hotline for Migrant Workers and Kav La'oved (2004), Immigration police as means for employers to exploit their workers. www.hotline.org.il/hebrew/pdf/Kav_Laoved_\%2526_Hotline_ report_A_tool_in_the_hands_of_employers_053104.pdf. (Hebrew)

Humphrey, M. (I993), 'Migrants, workers and refugees. The political economy of population movements in the Middle East', in Middle East Report, March-April: I-7.

Hyder, Z. (2008), A Door Opens For Reform in Pakistan - Part II. YaleGlobal online. http:// yaleglobal.yale.edu/content/door-opens-reform-pakistan-\%E2\%80\%93-part-ii.

Itō, M. (2005), Rizhi shidai houqi Taiwan zhengzhi sixiang zhi yanjiu - xilun Taiwan kangri yundongzhede zhengzhi sixiang [A study of political thought in Taiwan during the later Japanese colonial period - a discussion of the political thought of the anti-Japanese activists in Taiwan]. Taipei: Hongrutang Publishers.

Jacobson, D. (I996), Rights across borders: immigration and the decline of citizenship. Baltimore: Johns Hopkins University Press.

Jahan, S. (I993), 'Impact of the Gulf Crisis on the Bangladesh economy', in P. Wickramasekara (ed.), The Gulf Crisis and South Asia. Studies on the economic impact. New Delhi: UNDP/ILO Asian Regional Programme on International Labour Migration.

Jakarta Post (2004) Six ships laden with illegal logs enter Malaysia daily, 7 April.

Janardhan, M. (2004), 'New system offers legal cover for domestic workers', IPS News Agency, I5 June.

Jones, R (2009) 'Agents of Exception: Border Security and the Marginalization of Muslims in India', in Environment and Planning D: Society and Space 27: 879-97.

Ka, C. (I995), Japanese colonialism in Taiwan. Land tenure, development, and dependency, 18951945. Taipei: SMC Publishing Inc.

Kalir, B. (2005), 'The development of a migratory disposition: explaining a "new emigration"', in International Migration, 43 (4): I67-196.

Kalir, B. (2009), 'Finding Jesus in the Holy Land and taking him to China: Chinese temporary migrant workers in Israel converting to evangelical Christianity,' in Sociology of Religion, $70(2)$ : $130-156$. 
Kalir, B. (2010), Latino migrants in the Jewish State: undocumented lives in Israel. Bloomington: Indiana University Press.

Kapur, R. (2005), 'Travel plans: border crossings and the rights of transnational migrants', in Harvard Human Rights Journal I8: I07-I38.

Katz, P. (2005), When valleys turned blood red; the Ta-pa-ni incident in colonial Taiwan. University of Hawai'i Press: Honolulu.

Kav La'oved (1998), Newsletter May.

Kav La'oved (2000), Newsletter May.

Kemp, A., R. Raijman, J. Resnik \& S. Schammah-Gesser (2000), 'Contesting Qthe limits of political participation: Latinos and black African migrant workers in Israel', in Ethnic and Racial Studies 23 (I): 94-II9.

Khalaf, S. \& S. Alkobaisi (I999), 'Migrants' strategies of coping and patterns of accommodation in the oil-rich Gulf societies evidence from the UAE', in British Journal of Middle Eastern Studies 26 (2): 27I-298.

Khan, M.A. (2010), 'Bangladesh: Partitions, Nationalisms and Legacies for State-Building', London: School of Oriental and African Studies. http://www.eprints.soas.ac.uk/ı1685/

Kompas (I999) HPH, Hak Pembabatan Hutan [HPH, The Right to Prune the Forest], 30 August.

Kompas (2004) Gubernur Kaltim Minta Pelaku "Illegal Logging” Ditembak Mati [The Governor of East Kalimantan requests perpetrators of "illegal logging" to be shot dead], 2 August.

Krohn-Hansen, C. \& K.G. Nustad (2005), Introduction in C. Krohn-Hansen and K.G. Nustad (eds.), State Formation: Anthropological Perspectives. London: Pluto Press.

Kurien, P. (2002), Kaleidoscopic ethnicity: International migration and the reconstruction of community identities in India. London: Rutgers University Press.

Kwong, P. (I997), Forbidden workers: Illegal Chinese immigrants and American labor. New York: New Press.

Lefort, C. (I988), Democracy and Political Theory. Cambridge: Polity Press.

Lewa, C. (2008), 'Asia's new boat people', in Forced Migration Review 30: 40-42.

$\mathrm{Li}, \mathrm{M}$. (2004), 'Re-emergence of labour brokers in China today: the Xiamen example', in The Indian Society of Labour Economics 47 (3): 565-58I.

- (2006), 'Fujian migrant workers in Israel: making a living in an alien society', paper presented at the East-Asian anthropology/Anthropology in East Asia conference at the Chinese University of Hong Kong, I5 July 2006.

Liang, Z. \& H. Morooka (2004), 'Recent trends of emigration from China: I982-2000', in International Migration 42 (3): I45-I64.

Lim, L. \& N. Oishi (I996), 'International labor migration of Asian women: distinctive characteristics and policy concerns', in G. Battistella \& A. Paganoni (eds.), Asian Women in Migration, 23-53. Quezon City: Scalabrini Migration Center.

Lin, M. (I997), Cha, tang, zhangnaoye yu Taiwan zhi shehui jingji bianqian 1860-1895 [Tea, sugar and camphor and Taiwan's social and economic changes I895-I945]. Taipei: Lienching Publishing House.

Liu, B. (I98I), Meiguo Huaqiao shi [Chinese in the United States]. Taiwan: Liming chuban gongsi.

Long, S. (I99I), Taiwan: China's last frontier. Basingstoke/London: Macmillan Press.

Ludden, D. (2003a), 'Maps in the mind and the mobility of Asia', in The Journal of Asian Studies 62 (4): 1057-1078.

Ludden, D. (2003b), 'The first boundary of Bangladesh on Sylhet's northern frontiers', in Journal of the Asiatic Society of Bangladesh 48 (I): I-54.

MacIntyre, A. (I99I), Business and politics in Indonesia. Sydney: Asian Studies Association of Australia with Allen \& Unwin. 
Mackie, J. (1974), Konfrontasi: the Indonesia-Malaysia dispute, 1963-1966. Kuala Lumpur: Oxford University Press.

Marrus, M. (1985), The unwanted: European refugees in the twentieth century. New York: Oxford University Press.

Marsden, M. (2005), Living Islam: Muslim religious experience in Pakistan's north-west frontier. Cambridge: Cambridge University Press.

Massey, D., G. Arango, A. Hugo, A. Kouaouci, A. Pellegrino \& J. Taylor (I998), Worlds in motion, understanding international migration at the end of the millennium. Oxford: Clarendon Press.

McCarthy, John F. (2002), 'Turning in circles: district governance, illegal logging, and environmental decline in Sumatra, Indonesia', in Society and Natural Resources I5 (I0): 867-86.

McDuie-Ra, D. (20I2), 'Tribals, migrants and insurgents: Security and insecurity along the India-Bangladesh border', in Global Change, Peace and Security 24 (I) forthcoming.

McKeown, A. (2010), 'Chinese migration in global context, I850-1940', in Journal of Global History 5(I): 95-I24.

McMurray, D. (I999), 'Recent trends in Middle Eastern migration', in Middle East Report Summer: I6-I9.

Megoran, N., G. Raballand \& J. Bouyjou (2005), 'Performance, representation and the economics of border control in Uzbekistan', in Geopolitics IO (4): 7I2-40.

Menon, R. \& K. Bhasin (1998), Borders \& boundaries: women in India's partition. New Delhi: Kali for Women.

MERHROM (Myanmar Ethnic Rohingyas Human Rights Organization Malaysia) (2007), 'The situation of UNHCR-recognized stateless Rohingya refugees in Malaysia', http:// merhrom.wordpress.com/2007/07/23/the-situation-of-unhcr-recognized-stateless-rohingyarefugees-in-malaysia/, accessed I2 April 2009.

Ministry of Home Affairs, Government of India, Annual Report 2009-20Io. http://www. mha.nic.in/pdfs/AR(E)ogIo.pdf, accessed 3 January $201 \mathrm{II}$

Ministry of Labor (2000), Foreign Workers Deported from Israel 1995-1999, Jerusalem: Manpower Planning Authority (Hebrew).

Ministry of Labor (200I), Foreign workers without work permits in Israel: 1999, Discussion Paper n. 5.or. Jerusalem: Manpower Planning Authority (Hebrew).

Ministry of Labor (2002), Foreign workers without work permits deported from Israel in 2001. Jerusalem: Manpower Planning Authority (Hebrew).

Mitchell, T. (I988), Colonising Egypt. Cambridge: Cambridge University Press.

- (I999), 'Society, economy, and the state effect', in G. Steinmetz (ed.), State/culture: stateformation after the cultural turn, 76-97. Ithaca: Cornell University Press.

Mookherjee, N. (2008), 'Gendered embodiments: mapping the body-politic of the raped woman and the nation in Bangladesh', in Feminist Review 88 (I): 36-53.

Moore, S. (I973), 'Law and social change. The semi-autonomous social appropriate subject of study', in Law and Society Review 7 (4): 7I9-747.

Moors, A. \& M. de Regt (2008), 'Gender and irregular migration: migrant domestic workers in the Middle East', in M. Schrover, J. van der Leun, L. Lucassen \& C. Quispel (eds.), Gender and illegality, I49-I70. Amsterdam: Amsterdam University Press/IMISCOE.

Moors, A., R. Jureidini, F. Özbay \& R. Sabban (2009), 'Migrant domestic workers: a new public presence in the Middle East?', in S. Shami (ed.), I77-202. Publics, Politics and Participation: Locating the Public Sphere in the Middle East and North Africa. New York: SSRC Books.

Mohsin, A. (2004), 'Gendered Nation, Gendered Peace', in Indian Journal of Gender Studies II: $43-64$. 
Nath, H.K. \& S.K. Nath (20IO), 'Illegal Migration into Assam: Magnitude Causes and Economic Consequences', SHSU Economics \& Intl. Business Working Paper No. Iо-о6, December 20IO. http://papers.ssrn.com/sol3/papers.cfm?abstract_id=I750383.

Nathanson, R. \& R. Bar-Tzuri (I999), 'A survey of public opinion towards workers from foreign countries', in R. Nathanson \& L. Achdut (eds.), The new workers: wage earners from foreign countries in Israel. Tel-Aviv: Hakibbutz Hameuchad (Hebrew).

Netton, I. (I993), Golden roads: migration, pilgrimage and travel in mediaeval and modern Islam. Richmond: Curzon Press.

Ng, C. (1976), The Chinese in Riau: a community on an unstable and frontier. Research Project Series No. 2. Singapore: Institute of Humanities and Social Sciences, Nanyang University.

Niger-Thomas, M. (200I), 'Women and the arts of smuggling', in African Studies Review 44 (2): $43-70$.

Nordstrom, C. (2007), Global Outlaws: Crime, Money, and Power in the Contemporary World. Berkeley, CA: University of California Press.

Nyi Nyi Kyaw (2008), 'Rohingya Muslims: Myanmar's Forgotten People', RSIS Commentaries: Nanyang Technological University.

Nyiri, P. \& I. Saveliev (eds.) (2002), Globalising Chinese migration. Aldershot: Ashgate.

Nyiri, P. (2010), 'Foreign concessions: the past and future of a form of shared sovereignty', paper presented at the Vrije Universiteit Amsterdam, I7 December 2009. http://www.fsw. vu.nl/en/Images/Nyiri\%20-\%20Extraterritoriality_tcm3I-II6927.pdf

Obidzinsky, K., A. Andrianto \& C. Wijaya (2006), Timber smuggling in Indonesia. critical or overstated problem? Forest governance lessons from Indonesia. Bogor: Center for International Forestry Research.

Obidzinsky, K., A. Andrianto \& C. Wijaya (2007), 'Cross-border timber trade in Indonesia: critical or overstated problem? Forest governance lessons from Kalimantan', in International Forestry Review 9 (I): 526-535.

Ong, A. \& D. Nonini (eds.) (I997), Ungrounded empires, the cultural politics of modern Chinese transnationalism. New York/London: Routledge.

Osella, F. \& C. Osella (2000), 'Migration, money and masculinity in Kerala', in Journal of Royal Anthropological Institute 6 (I): II7-I33.

Padoch, C. (1983), 'Agricultural practices of the Kerayan Lun Dayeh', in Borneo Research Bulletin I5: 33-38.

Peachey, K., M. Perry \& C. Grundy-Warr (1998), 'The Riau Islands and economic cooperation in the Singapore-Indonesian border zone', in Boundary and Territory Briefing 2 (3): I-59.

Percot, M. (2006), 'Indian nurses in the Gulf: two generations of female migration', in South Asia Research 26 (I): 4I-62.

Pereira, A. (2004), 'State entrepreneurship and regional development: Singapore's industrial parks in Batam and Suzhou', in Entrepreneurship and Regional Development I6: 129-44.

Perera, K. (2008), 'Lessons from the Rohingya Muslim Crisis', Daily Mirror, 20 September 2008.

Phiri, P. (2009), 'Rohingyas and refugee status in Bangladesh', in Forced Migration Review, 30: 34-35.

Pieke, F. (2004), 'Chinese globalization and migration to Europe', Working Paper No. 94. San Diego: University of California.

Pieke, F., P. Nyiri, M. Thuno \& A. Ceccagno (2004), Transnational Chinese: Fujianese migrants in Europe. Stanford: Stanford University Press.

Pieke, F. (2005), 'Community and identity in the new Chinese migration order', Working Paper No. 24. COMPAS: University of Oxford.

Polanyi, K. (I944), The great transformation: the political and economic origins of our time. Boston: Beacon Press. 
Prakash, B. (1978), 'Gulf migration and its economic impact: the Kerala experience', in Economic and Political Weekly, December I2, 33 (50): 3209-3213.

Prakash, B. (2000), 'Exodus of Gulf emigrants-return emigrants of Varkala Town in Kerala', in Economic and Political Weekly, December I6, 35 (51): 4534-4540.

Prokkola, E. (2008), 'Border narratives at work: theatrical smugglilng and the politics of commemoration', in Geopolitics I3 (4): 657-75.

Rabinowits, D. (1997), Overlooking Nazareth: the ethnography of exclusion in Galilee. Cambridge: Cambridge University Press.

Radar Tarakan (2008), 2007, Illegal logging di Urutan Pertama. 2 August.

Ramachandran, S. (2003), “'Operation Pushback” - Sangh Parivar, state, slums, and the surreptitious Bangladeshis in New Delhi', in Economic and Political Weekly 38 (7): 637-647.

Refugees International (2008), 'Rohingya: Burma's Forgotten Minority', I8 December 2008, http://www.unhcr.org/refworld/docid/494f53e72.html, accessed I2 April 2009.

Reid, A. (1983), Slavery, bondage and dependency in Southeast Asia. New York: University of Queensland Press.

Roitman, J. (2004), 'Productivity in the Margins: The Reconstitution of State Power in the Chad Basin', in V. Das \& D. Poole (eds.), Anthropology in the Margins of the State. Oxford: James Currey Ltd.

Roitman, J. (2005), Fiscal disobedience: An anthropology of economic regulation in Central Africa. Princeton: Princeton University Press.

Roy, O. (1986), Islam and resistance in Afghanistan. Cambridge: Cambridge University Press.

Sabban, R. (2002), 'United Arab Emirates: migrant women in the United Arab Emirates, the case of female domestic workers', Genprom working paper No.9. series of Women and Migration. Gender Promotion Programme, International Labour Office Geneva.

Sabban, R. (2004), 'Women migrant domestic workers in the United Arab Emirates', in S. Esim \& M. Smith (eds.), Gender and migration in Arab States: the case of domestic workers, 85-104. Beirut: ILO.

Saikia, Y. (20II), Women, War, and the Making of Bangladesh: Remembering 1971. Durham: Duke University Press.

Samaddar, R. (1999), The marginal nation: Transborder migration from Bangladesh to West Bengal. New Delhi: Sage Publications.

Saphiro, M. (I994), 'Moral geographies and the ethics of post-sovereignty', in Public Culture 6: $479-502$.

Sassen, S. (1999), Guests and aliens. New York: The New York Press.

Sassen, S. (2003), 'Globalization or denationalization?', in Review of International Political Economy Iо (I): I-22.

Schnell, I. (I999), Guidelines for policy making towards foreign workers in Israel. (Hebrew) Jerusalem: The Israeli Centre for Political and Social Research

Schnell, I. (200I), Foreign workers in southern Tel Aviv-Yafo. (Hebrew) Jerusalem: Floersheimer Institute for Policy Studies.

Schrover, M., J. van der Leun, L. Lucassen \& C. Quispel (eds.) (2008), Gender and illegality. Amsterdam: Amsterdam University Press/IMISCOE.

Scott, J. (1998), Seeing like a state. How certain schemes to improve the human condition have failed. New Haven: Yale University Press.

Semyonov, M., R. Raijman, \& A. Yom-Tov (2002), 'Labour market competition, perceived threat, and endorsement of economic discrimination against foreign workers in Israel', in Social Problems 49 (3): 4I6-43I.

Shah, N. (2005), 'Restrictive labour immigration policies in the oil-rich Gulf: implications for sending Asian countries', paper presented at XXV IUSSP International Population Conference, Tours, France, I8-23 July 2005. 
Sial, S. \& A. Yousufzai (2008), 'Tribal areas: what will FCR be replaced with?', in South Asia Net, Pakistan. http://san-pips.com/PIPS-SAN-Files/SAN-Pakistan/SAN-PAK-Article62/SanPak-Main-A62-D.asp

Skeldon, R. (2000), Myths and realities of Chinese irregular migration. Geneva: International Organization for Migration.

Smith, P. (ed.) (I997), Human smuggling: Chinese migrant trafficking and the challenge to America's immigration tradition. Washington, D.C.: The Center for Strategic and International Studies.

Song, W. (I937), Taiwan to Shinajin Rodosha - yū ni kansuru hitotsu no chōsa hōkokusho [Taiwan and its Chinese workers - an investigation report], Nanshi Nanyô Kenkyû [South China and South Pacific Studies] vol. 28, Taipei: Taihoku kôgyôshôgyôgakkô Nanshi Nanyô keizai kenkyûkai.

Song, W. (I943), ‘Taiwan no Kakyō’ [Taiwan's Chinese sojourners]. Taiwan Keizai Nenpō [The Taiwanese Economy Yearbook], Tôkyô: 400-445.

Soja, E. (I989), Postmodern geographies: the reassertion of space in critical social theory. New York: Verso.

Sparke, M., J. Sidaway, T. Bunnell \& C. Grundy-Warr (2004), 'Triangulating the borderless world: geographies of power in the Indonesia-Malaysia-Singapore growth triangle', in Transactions of the Institute of British Geographers 29: 485-98.

Squire, V. (20II), 'The Contested Politics of Mobility: Politicizing Mobility, Mobilizing Politics', in V. Squire (ed.), The Contested Politics of Mobility: Borderzones and Irregularity. London: Routledge.

State Comptroller (I996), Annual Report no. 46, Jerusalem (Hebrew).

State Comptroller (I999), Annual Report no. 49, Jerusalem (Hebrew).

State Comptroller (2003), Annual Report no. 53, Jerusalem (Hebrew).

Steinmetz, G. (I999), State/culture: state-formation after the cultural turn. Ithaca: Cornell University Press.

Suhrke, A. (I993), 'The "high politics" of population movements: migration, state and civil society in Southeast Asia', in M. Weiner (ed.), International Migration and Security, I79-200. Boulder: Westview Press.

Sur, M. (forthcoming), Jungle Passports and Metal Fences - Living on the Border between Northeast India and Bangladesh, PhD Dissertation, University of Amsterdam.

Suryadinata, L. (I98I), Peranakan Chinese politics in Java 1917-1942. Singapore: Singapore University Press.

Tagliacozzo, E. (2007), Secret trades, porous borders: smuggling and states along a Southeast Asian frontier, 1865-1915. Singapore: National University of Singapore Press.

Tan, P. (2008), Komuniti dalam pembentukan: Migrasi dan penyesuaian komuniti Rohingya di Lembah Klang [Community in formation: migration and adaptation of the Rohingyas in the Klang Valley]. Unpublished masters' thesis, Universiti Kebangsaan Malaysia.

Tang, C. (2002), Xiamen yu Taiwan [Xiamen and Taiwan]. Xiamen: Lujiang Publishers.

Tempo (2005). Pembalakan Liar Masih Marak di Nunukan [Illegal Logging Still Flares in Nunukan], 2I September.

The Assam Tribune (2OII), Meghalaya-Bangla border Haats likely to be opened in March, Shillong, February 6.

The Daily Star (2008), 'Myanmarese refute charges against Bangladeshis', 26 April 2008. http://www.thedailystar.net/story.php?nid=3385I, accessed I2 February $201 \mathrm{I}$.

Tirtosudarmo, R. (2004), 'Cross-border migration in Indonesia and the Nunukan Tragedy', in A. Ananta \& E. Arifin (eds.), International Migration in Southeast Asia, 310-330. Singapore: ISEAS Publications.

Tirtosudarmo, R. (2005), 'Nunukan sebagai wilayah transit' [From Entikong to Nunukan. Dynamics of the Kalimantan East Malaysia (Serawak Sabah) Border Areas], in R. Tirtosu- 
darmo \& J. Haba (eds.), Dari Entikong sampai Nunukan. Dinamika daerah perbatasan Kalimantan Malaysia Timur (Serawak-Sabah) [From Entikong to Nunukan. dynamics of the Kalimantan East Malaysia (Serawak Sabah) border areas], I53-I84. Jakarta: Pustaka Sinar Harapan.

Tremblay, P., M. Cusson \& C. Morselli (I998), 'Market offenses and limits to growth', in Crime, Law and Social Change 29: 3II-30.

Trocki, C. (I979), Prince of the pirates: the Temenggongs and the development of Johor and Singapore, 1784-1885. Singapore: Singapore University Press.

Trocki, C. (I990), Opium and empire. Ithaca: Cornell University Press.

Ts'ai, H. (2009), Taiwan in Japan's empire building, an institutional approach to colonial engineering. London/New York: Routledge.

Torpey, J. (2005), 'Imperial embrace? Identification and constraints on mobility in a hegemonic empire', in I. Toshio and I. Masako (eds), Motion in Place/Place in Motion, $21^{\text {st }}$ Century Migration, 65-82. Osaka: Japan Center for Area Studies.

Twang, P. (1998), The Chinese business elite in Indonesia and the transition to independence 19401950. Kuala Lumpur: Oxford University Press.

United States Committee for Refugees and Immigrants (I999), 'U.S. Committee for Refugees World Refugee Survey I999 - Malaysia’, I January I999, http://www.unhcr.org/ refworld/docid/3ae6a8a22c.html, accessed I2 April 2009.

Urry, J. (2007), Mobilities. Cambridge: Polity.

Van Schendel, W. (I992), "The invention of the "Jummas": state formation and ethnicity in Southeastern Bangladesh', in Modern Asian Studies 26 (I): 95-I28.

- (I993), 'Easy come, easy go: smugglers on the Ganges', in Journal of Contemporary Asia 23 (2): $189-213$.

- (200I), 'Working through partition: making a living in the Bengal borderlands', in International Review of Social History 46: 393-421.

- (2005), The Bengal borderland: beyond state and nation in South Asia. London: Anthem Press.

Van Schendel, W. \& I. Abraham (2005), 'Introduction: the making of illictness', in Van Schendel, W. \& I. Abraham (eds.), Illicit flows and criminal things: states, borders, and the other side of globalization, 22-25. Bloomington: Indiana University Press.

Varghese, V. (2008), 'Promoting or proscribing women's movement? Overseas recruitment system in India', paper presented at the workshop on 'Illegal but Licit: Transnational Flows and Permissive Polities in Asia', Centre for Development Studies, Trivandrum, 24-25 January.

Verkaaik, O. (2004), Migrants and militants: 'fun' and urban violence in Pakistan. Princeton: Princeton University Press.

Visvanathan, S. and H. Sethi (I998), 'By Way of a Beginning', in S. Visvanathan \& H. Sethi (eds.), Foul Play: Chronicles of Corruption 1947-97. New Delhi: Banyan Books.

Von Benda Beckman, F., von, K. von Benda Beckman \& J. Eckert (2009), Rules of Law and Laws of Ruling: On the Governance of Law. Farnham, UK: Ashgate.

Von Benda Beckmann, F., K. von Benda Beckmann \& A. Griffiths (2005), Mobile people, mobile law. Expanding legal relations in a contracting world. Aldershot: Ashgate.

Wacquant, L. (1996), 'Foreword', in P. Bourdieu, The state nobility: elite schools in the field of power, ix-xxii. Cambridge: Polity.

Wadley, R. (200I), 'Community co-operatives, illegal logging and regional autonomy in West Kalimantan, Indonesia', paper presented at the conference 'Resource tenure, forest management and conflict resolution; Perspectives from Borneo and New Guinea', Canberra, 9II April 200I. 
Walker, A. (I999), The legend of the golden boat: regulation, trade and traders in the borderlands of Laos, Thailand, Burma and China. Richmond: Curzon Press.

Wang, B. (2005), Mei fating nanpan 'toudu huanghou' an, zuizhong xuanpan yizai tuichi [American Court cannot settle the lawsuit of 'smuggling queen', the final judgment has to be suspended once again]. http://news.xinhuanet.com/overseas/2005-06/28/content_ 3147369_2.htm.

Wang, G. (I98I), Community and nation: essays on Southeast Asia and the Chinese. Singapore: Heinemann Educational Books Ltd.

Weber, R. (I995), 'Re(creating) the home: women's role in the development of refugee colonies in South Calcutta', in Indian Journal of Gender Studies 2 (2): 195-210.

Weiner, M. (I982). 'International migration and development: Indians in the Persian Gulf, in Population and Development Review. 8 (I): I-36.

Willen, S. (2007), 'Toward a critical phenomenology of "illegality": State power, criminalization, and abjectivity among undocumented migrant workers in Tel Aviv, Israel', in International Migration, 45(3): 8-38.

Willoughby, J. (2005), 'Ambivalent anxieties of the South Asian-Gulf Arab labor exchange', Working Paper Series, Department of Economics, American University, Washington DC.

Wilson, T.M. \& H. Donnan (eds.) (2005), Culture and Power at the Edges of the State: National Support and Subversion in European Border Regions. Münster: LIT Verlag.

Wiltshire, S., A. Bancroft, A. Amos \& O. Parry (200I), “They're doing people a service”: qualitative study of smoking, smuggling, and social deprivation', in British Medical Journal 323: 203-7.

Wong, D. (2005), 'The rumor of trafficking: border controls, illegal migration, and the sovereignty of the nation-state', in W. van Schendel \& I. Abraham (eds.), Illicit Flows and Criminal Things, 69-100. Bloomington: Indiana University Press.

Wu, W. (I99I), Riju Shiqi zai Tai 'huaqiao' zhi yanjiu [A study of the huaqiao in Taiwan during the Japanese period]. Taipei: Taipei Xuesheng Shuju.

Wu, Z. (2006), Orphan of Asia, a novel [translated by Ioannis Mentzas]. New York City: Columbia University Press.

Xiang, B. (2003), 'Emigration from China: a sending country perspective', in International Migration 4I (3): 2I-48.

XMMYZ editing committee (ed.) (I998), Xiamen duiwai jingji maoyi zhi [History of foreign trade in Xiamen]. Beijing: Zhongguo tongji chubanshe.

XMNJ (I998), Xiamen shehui fazhan nianjian [Almanac of the social development in Xiamen]. Xiamen: Xiamen University Press.

Xu, X. (I991a), 'Ping-Riju shiqi zai Tai “Huaqiao" zhi yanjiu-yishu [Comments on "A Study of the "huaqiao" in Taiwan during the Japanese period'], in: Taiwanshi tianye yanjiu tongxun [Newsletter of Taiwan History Field Research] I9: 42-45.

Xu, X. (I99Ib), 'Taiwan Zhonghua Zonghuiguan chengli qiande Taiwan huaqiao I895-I927' [The Taiwan huaqiao before the establishment of the Chinese General Association I895I927], Zhongyang Yanjiuyuan Jindaishi Yanjiusuo Jikan [Collected Papers of the Institute for Modern History of the Academia Sinica] vol. 20: 99-I29.

$\mathrm{Xu}$, X. (I992), 'Gao Minghong yu Riju shiqide qiaoyun' [Gao Minghong and the fate of the Taiwan huaqiao during the Japanese period], in: Haiwai Huaren Yanjiu [Journal of Overseas Chinese Studies] 2: I-40.

Xu, X. (I993), 'Taiwan Zhonghua Zonghuiguan yu Riju shiqide huaqiao 1929-1937' [The Chinese General Association on Taiwan and the huaqiao during the Japanese period I929-I937], in: Shilian Zazhi [The Historical Connections Journal] 22: 67-94.

Xu, X. (I995), 'Taiwan Huaqiao touzi Fuzhou Fuxing Qichegongsi shimo 1931-1936' [The ins and outs of the Taiwan Huaqiao's investments in the Fuxing Automobile Company I93I-I936], 
in: Zhongyang Yanjiuүuan Taiwanshi Yanjiu [Academia Sinica Taiwan History Studies] 2 (I): $5 \mathrm{I}-84$.

$\mathrm{Xu}, \mathrm{X}$. (1997), 'Rizhi shiqide “Taiwan Huaqiao” I937-I945' [The 'Taiwan Huaqiao' during the Japanese period], Z. Yanxian (ed.), Zhongguo Haiyang fazhan shilun wenji [Collection of essays on the history of China's overseas development], vol. 6, 499-549. Taipei: Zhongyang Yanjiuyuan Zhongshan Renwenshehuikexue Yanjiuso.

Yanay, U. \& A. Borowosky (1998), 'Foreign workers in Israel: rights and access to welfare services' (Hebrew), in Social Security 53: 59-78.

Yeung, H. (1998), 'The political economy of transnational corporations: a study of the regionalization of Singaporean firms', in Political Geography I7 (4): 389-4I6.

Yiftachel, O. (1997), 'Israeli society and Jewish-Palestine reconciliation: ethnocracy and its territorial contradictions', in Middle East Journal 5I (4): 505-519.

Yong, M. (2003), The Indonesian revolution and the Singapore connection, 1945-1949. Singapore: Singapore University Press.

Yuan, D. (2002), Jindia qiaozheng yanjiu [A study of modern overseas Chinese policy]. Hong Kong: Tienma Press.

Zachariah, K. \& S. Irudaya Rajan (200I), 'Gender dimension of migration in Kerala: macro and micro evidence', in Asia-Pacific Population Journal I6 (3): 47-70.

Zacharia, K., B. Prakash \& S. Irudaya Rajan (2002), 'Gulf migration study: employment, wages and working conditions of Kerala emigrants in the United Arab Emirates', Working Paper no. 326. Centre for Development Studies, Thiruvananthapuram.

Zacharia, K., B. Prakash \& S. Irudaya Rajan (2004), 'Indian workers in UAE: employment, wages and working conditions', in Economic and Political Weekly 39 (22): 2227-2234.

Zhuang, G. (1989), Zhongguo Fengjian Zhengfudu Huaqiao Zhengce [The overseas Chinese policies of China's feudal government]. Xiamen: Xiamen University Press.

Zolberg, A. (1983), 'The formation of new states as a refugee generating process', in The Annals 467: 24-38. 


\section{Index}

Abraham, Itty I9, 20, 27, 47, 48, IO०, I06, IIO, III, I28, I33, I45, I47, I48, I62, I70, I74

Adat I3, 22, II6-I2I, I25

Afghanistan 49, 55, 57-61, 67, 68, 79, 168

Agamben I6, 52, 57, 76, 79

Airport 23, I57, I58, I60, I76, I85, I86, 220

Asylum 5I, 76, 79

Bangladesh 77, 80-87, 90, I27-I39, I4I-I5O

Belonging I2, I5, 2I, 24, 5I, 53, I28, I45, I55, 236

Body I2, 23, 59, 6I, 69, I27, I28, I3I-I33, I43-I47, I73, 2I4, 223 politics I28, I44, I46,

Bondage I43, I46, I47

Border crossing 75, 96, III, II2, II5, I20, I22, I25, I27, I28, I30, I33, I39, I45, I46, I47, I54, I57, I64

Borderland I7-I9, 2I, 22, 23, 47, 48, 55, 57, 58, 91, 93, Іоо, Іог, І03, I05, I07, I28-I3I, I33, I35, I38, I4I, I42, I45, I46, I47, I49, I5O, 237

Boundaries I4, 27, 77, 104, I29, I38, I43, I52, I62, I64, I77, I80, 229, 23I, 233, 237, 238

Brokerage see Brokers

Brokers I6, I9, 25, 62, I27, I34, I43, I98, 207-2I3, 2I5-224, 230-233

Capital 33, 38, 6I, 85, 87, 98, III, II3, II9, 224
Capitalism $47,48,77,78$, iाо

China I5, I6, 20, 24, 25, 27-32, 35, $36,38,39,44,45,53,54,78$, II2, I29, I89-196, I98-219, 221-223, $225,233,235,237$

Citizenship I3, I9, 75, 79-84, 86, I07, I29-I3I, I33, I37, I45, I54, I62, I70, I72, I73, I79, I80, I83, I89, 202, 203, 232

Commodity 22, 95, IOI, I08, I27129, I36, I38, I39, I45, I93, 196, 209, 224, 238

Conflict 62, 67, 73, 9I, IO6, II8, 200, 230, 238, 24I

Consumption 97, I39

Controlled Informality I2, 20, 24, I62, I7I, I76, I77, I83

Corruption $58,63,66,92,103,104$, І06, I07, I26, I85, 224, 228

Crisis 4I, 48, 49, 56, 62, 76, 86, 99

Culture 2I, 50, 55-58, 6I-66, 68, 7073, 9I, 97, I85

Custom I3, I7, I9, 2I, 55, 56, 58, 60, 63-67, 69-7I, 73, 97-99, I01, 105, I07, IIO, II3, II7, II9, I2I, I22, I26, I34, I38, I95, I97, I99, 23I

De Genova, Nicholas 52, I33, 235, 236

Deportation I5, 20, 2I, 35, 40, 44, $46,50,88, \mathrm{I} 29, \mathrm{I} 30, \mathrm{I} 32, \mathrm{I} 33, \mathrm{I} 42$, I44, I46, I47, 223, 235

Discourse I9, 2I, 55-57, 6I, 62, 68, 70-72, 80, IO2, IO3, IO6, III, II2, I23, I25, I28, I29, I47, I49, I55, 
I56, I74, I78, I90, I99, 200, 202, 203, 232

Donnan, Hastings 9I, I07, I3I, 23I

Dubai I5, 23, I5I-I53, I55-I62, I64, I66, I67

Elite I3, I7, 22, 49, IIO, I23-I26, I33, I73, I9I, I93, 204

Enforcement 35, 43, 45, II8, I29

Entrepreneur 32, 99, I00, I02, I04, I36, I4I, 224, 225, 230

Exploitation I5, I6, 20, 37, 42, 45, I52, I59, I62, I66, I69, I70, I73, I77, I79, I80, I82, I83, I86, I90, 198, 199, 205

Ferguson, James 234, 238

Foreigner I6, I9, 20, 73, 83, 84, 89, II9, I29, I32, I34, I37, I38, I44, I47, I89, I9I, I92, I95, I98, I99, 205

Foucault, Michel I7, I75

Gender I6, I9, 24, 69-7I, I27, I29I33, I46-I48, I5I, I62, I64, I69-I74, I77-I80, I83, I84, 238

Globalisation 208, 224

Governance 89, I04, II7, I2I, 229, 232

Gulf States I8, 37, 8I, 83, I76, I8I, I86, 232

Heyman, Josiah I6, ıо9, Iıо, 230, 23I

Hospitality I3, 2I, 64, 75, 79, 85, 87, 90

Huaqiao 24, 25, I9I, 202, 205, 233

Human mobility 229, 230, 238, 239

Human rights I3, 2I, 46, 55, 56, 68, 7I, 72, 76, I28, I43, I52, I66 Human trafficking $\mathrm{I} 4,24,38$
Identity I2, I7, 5I, 82, 83, IO7, ІІ6, ІІ8, І33, І37, І46, І48, г68, I77, 235,236

Illegal but Licit I3, 20, 22, 23, 25, $27,47,48,52,53,74, \mathrm{I} 33, \mathrm{I} 46-\mathrm{I} 48$, I67, I70, I90, I93, 223, 229, 232

Implementation deficiency I2, I4 India I5, I7-I9, 21, 23, 24, 28, 59, 77, 8I, 86-88, 90, I27-I47, I49, I5I, I53-165, I67-I69, I72-I76, I78, I80I87, 232, 235, 238

Indonesia I3, I6, I7, I9, 22, 23, 8I, 91, 92, 94-100, I02, I03, I05-I27, I67, I8I, I82, 2I2, 235, 237

Israel 9, I3-I6, I8, 20, 25, 27-47, 5054, 57, II2, I85, 2I6-2I8, 222, 23I, 233, 237

Kerala I5I-I6I, I65-I7I, I75-I8I, I83I86, 23 I

Legitimacy I2, I5, I6, 23, 32, 47-50, 53, 56, 72, I27-I29, I45, I47, I48, I56, 23I

Locality I2, I4

Loyalty I2, 25, 206, 2I3

Malaysia I3, I7, I9, 2I-23, 75, 76, 8488, 90, 92, 95-102, 104-106, 109, II2-I23, I26, I67

Media 43, 8I, 85, I53, I54, I63, I64, I72, I85, I86, I94, 203, 2I9, 22I

Meghalaya 23, I29, I3I, I34-I39, I4I, I48-I5O

Migration policy $47, \mathrm{I} 83, \mathrm{I} 85,208$, 2II

Militarisation 60, I27-I29, I3I, I32, I37, I38, I47, I97

Mobilities II, I6, 23, I27, 229, 237

Moral geographies I8, 236

Moral panic 24, I64

Nationalism 21, 55, 56, 68, 70, 73, II2 
Network I9, 2I, 22, 24, 4I, 77, 85, III, II2, I2I, I5I, I54, I58-I60, I72, I76, I84, I86, 204, 207, 2I2, 222, 223,234

NGOs 3I, 35, 42-47, 68, 234

Nunukan 2I, 22, IOI, IO9-II3, II6II8, I2I-I26

Pakistan 9, I3, I6, I8, 21, 55-6I, 63, $65-68,70,72,73,80-85,90,132$, I34, I35, 232

Passport I9, 32, 43, 84, 96, I35-I37, I4I, I42, I44, I46, I49, I5I, I55, I59, I60, I63, I73-I75, I84-I86, I92 Population I3, 2I, 24, 28, 55, 58, 59, 6о, 6г, 64, 67, 68, 73, 75-8г, 83-87, 89, 90, ІІо-ІІ3, ІІ5-І2І, І26, І29, I34, I48, I53, I67, I89, I92, I95, 196, 198, 203, 204

Prostitute I74, I97, I9 8

Protectionism 24, I46, I69-I72, I82, I83

Public opinion $20,46,47,50,51$, I80, I94

\section{Regimes}

migration 24, 27, 46, 83, I73, I89-I9I, I93, I94, I99, 205

political I3, 99, I33

of permissiveness I9, I42, I44

Regulatory authority I2-I4, I6, I7, 9I, IOO

Repatriation 80, 8I, I74, 205

Resettlement see Settlement

Riau Islands 2I, 22, 9I-94, IOO-IO2, I06-I08, II2

Risk I6, I8, I9, 23, 33, 38, 40, 52, I00, I20, I27, I37, I63, I64, I66, I68, I80, 220, 238

Rohingyas I8, 2I, 75, 76, 80-89, 236

Roitman, Janet I6, 23I, 232

Saudi Arabia I3, I8, 2I, 80, 8I, 8386,89 , I5I, I59, I66, I67
Scott, James I2, 89

Security I8, 50, 86, IO3, II7, I2I, I27-I29, I34, I37, I39, I4I, I45, I46, I50, I55, I62, I68, I69, I76, I79I82, 238

Settlement 20, 30, 4I, 75-77, 79, 80, $83,86-88$, I32, I37, I45, I90, I95, I96, I99

Shame 24, 65, I74, I80

Singapore 22, 23, 92-IO7, II2, II3, I90, 209, 225

Slavery 25, II4, I25, I3I, I84, 208

Smuggling I8, 25, 54, 58, 64, 68, 83, 85, 9I-Іо8, ІІ2, І22-I25, I27, I34, I44, 207, 219, 220, 223, 23I, 237, 238

human 24, 222, 223

Snakeheads 32, 219-223

Sovereignty $12,18,24,52,53,56$, II3, I44, I45, I62, I70, I72, I73, I79, I80, I83

Taiwan 20, 24, 25, 77, II2, I89-205, 206, 233

Tel Aviv I5, 28, 50

The Philippines 22, 28, 8I, II2, II3, I64, I68, I8I, I82, I84

Trans-border I9, 22, 23, 76, I27-I30, I32, I34-I39, I43-I45, I47

Transgression I09, I45, I79

Transnational flows II, I6, I7, I9, 47, I47, 229

migration $24,25,75,76, \mathrm{I} 46$, 207, 2I2, 2I3, 2I5, 2IG, 2I9, 222, $223,225,229$

network 2I, 23, 25, 2I3, 22I

Undocumented migration (also migrants) 3I, 39-44, 46, 50, 52, $54, \mathrm{I} 28,223,235,236$

United Arab Emirates 9, I4, I9, 23, 8I, I5I, I53-I55, I57-I63, I66-I68, I75, I76, I8I, I82 
Van Schendel, Willem I9, 20, 27, Work permit 33-35, 42, 85, 216, 237 47, 48, 9I, IOO, IO6, IIO, III, I28, I3I, I33, I34, I45-I50, I62, I70, I74 Victim I8, 23, 33, 58, 77, I27, I3I, I5I, I52, I56, I63, I64, 222 Workers domestic I5, 23, I5I, I52, I54-I59, I62-I64, I66-I7I, I73, I75-I83, เ86, I87

Violence I3, I7, 23, 49, 5I, 58, 69, I27-I29, I3I, I33, I42, I44, I46-I48, I59, I65 Visa I9, 28, 32-40, 54, 83, I2I, I5I, I55-I63, I66, I74, I77, I84, I85, I98 


\section{IIAS Publications Series}

International Institute

for Asian Studies

Josine Stremmelaar and Paul van der Velde (eds.)

What about Asia? Revisiting Asian Studies

2006 (ISBN 978905356959 7)

\section{Monographs}

Alex McKay

Their Footprints Remain. Biomedical Beginnings Across the Indo-Tibetan

Frontier

Monographs I

2007 (ISBN 9789053565186 )

Masae Kato

Women's Rights? The Politics of Eugenic Abortion in Modern Japan Monographs 2

2009 (ISBN 978905356793 7)

Jeroen de Kloet

China with a Cut. Globalisation, Urban Youth and Popular Music

Monographs 3

2010 (ISBN 978908964 I62 5)

Rituparna Roy

South Asian Partition Fiction in English. From Khushwant Singh to Amitav Ghosh

Monographs 4

20I0 (ISBN 978908964245 5)

Chaiyakorn Kiatpongsan

The EU-Thailand Relations. Tracing the Patterns of New Bilateralism Monographs 5

2OII (ISBN 978908964 I64 9) 
Olena Mykal

The EU-Japan Security Dialogue. Invisible but Comprehensive Monographs 6 2OII (ISBN 978908964 I63 2)

Kah Seng Loh, Edgar Liao, Cheng Tju Lim and Guo-Quan Seng The University Socialist Club and the Contest for Malaya. Tangled Strands of Modernity

Monographs 7

2012 (ISBN 978908964409 I)

Eka Srimulyani

Women from Traditional Islamic Educational Institutions in Indonesia.

Negotiating Public Spaces

Monographs 8

2012 (ISBN 978908964421 3)

Duncan McDuie-Ra

Northeast Migrants in Delhi. Race, Refuge and Retail

Monographs 9

2012 (ISBN 978908964422 o)

\section{Edited Volumes}

Gijsbert Oonk (ed.)

Global Indian Diasporas. Exploring Trajectories of Migration and Theory Edited Volumes I 2007 (ISBN 9789053560358 )

Wen-Shan Yang and Melody Chia-Wen Lu (eds.)

Asian Cross-border Marriage Migration. Demographic Patterns and Social Issues

Edited Volumes 2

20I0 (ISBN 978908964054 3)

Margaret Sleeboom-Faulkner (ed.)

Frameworks of Choice. Predictive and Genetic Testing in Asia Edited Volumes 3

20Iо (ISBN 978908964 I65 6) 
Birgit Abels (ed.)

Austronesian Soundscapes. Performing Arts in Oceania and Southeast Asia Edited Volumes 4

2OII (ISBN 9789089640857 )

Dipika Mukherjee and Maya Khemlani David (eds.)

National Language Planning and Language Shifts in Malaysian Minority

Communities

Edited Volumes 5

2OII (ISBN 978908964 27I 4)

Gregory Bracken (ed.)

Aspects of Urbanization in China. Shanghai, Hong Kong, Guangzhou

Edited Volumes 6

2OI2 (ISBN 978908964398 8) 